\title{
Shifting Ground: \\ Urban Trauma and the Spatial Impacts of The Troubles In Derry, Northern Ireland
}

\author{
Austin Reid Walker \\ B.S. in Architecture \\ University of Virginia, 2014 \\ Thesis Committee: \\ Sheila Crane, chair \\ Shiqiao Li \\ Christa Robbins
}

A Thesis Presented to the Faculty Of the Department of Architectural History

In the School of Architecture

At the University of Virginia

In Partial Fulfillment of the Requirement for the Degree Master of Architectural History

May 2017 
Table of Contents

List of Illustrations

Acknowledgements

Introduction

11

Chapter 1: Urban Events and Upheaval in "Free Derry"

Chapter 2: Political Murals, Ephemeral Tactics, and the Symbolic Landscape in Derry

Conclusion

Bibliography

Illustrations 
List of Illustrations

Chapter 1:

Figure

1.1. Original hand-painted "Free Derry" slogan, January 1969. Digital image. Museum of Free Derry, http://www.museumoffreederry.org/content/free-derry.

1.2. Diagrammatic map of Derry, showing basic street layout, army barricades, and Catholic barricades during the Battle of the Bogside. Russell Stetler, The Battle of Bogside: The Politics of Violence in Northern Ireland (London: Sheed \& Ward, 1970), 72.

1.3. Photograph showing the RUC charge into Rossville Street, supported by Protestant civilians, during the Battle of the Bogside. Russell Stetler, The Battle of Bogside: The Politics of Violence in Northern Ireland (London: Sheed \& Ward, 1970).

1.4. Photograph showing the Rossville Street barricade during the Battle of the Bogside. Russell Stetler, The Battle of Bogside: The Politics of Violence in Northern Ireland (London: Sheed \& Ward, 1970).

1.5. Photograph showing the RUC firing CS gas towards the Rossville Street barricade during the Battle of the Bogside. Russell Stetler, The Battle of Bogside: The Politics of Violence in Northern Ireland (London: Sheed \& Ward, 1970).

1.6. Photograph showing a Bogside youth stationed atop the Rossville Flats, with several petrol bombs nearby. Digital image. Gilles Caron, 1969, Contact Press Images. http://contact.photoshelter.com/gallery-image/Gilles-Caron-Northern-Ireland-August1969/G0000eaXGnX5RBQo/I0000PIFqZiU4gGU.

1.7. Photograph showing women and children producing petrol bombs during the Battle of the Bogside. Digital image. Museum of Free Derry, http://www.museumoffreederry.org/content/12-14-august.

1.8. Photographs showing Bernadette Devlin, Republican activist, coordinating efforts during the Battle of the Bogside. Gilles Caron, 1969, Contact Press Images. http://contact.photoshelter.com/gallery-image/Gilles-Caron-Northern-Ireland-August1969/G0000eaXGnX5RBQo/I0000ET07fRRZrjo

1.9. Photograph showing the Rossville Flats during the Battle of the Bogside, with Irish tricolor and Starry Plough flags visible at rooftop corners of the building on the left. Digital image. Museum of Free Derry, http://www.museumoffreederry.org/content/battle-bogside.

1.10. Photograph showing the Irish tricolor flag being flown by Bogside youths stationed on the roof of the Rossville Flats. Digital image. Museum of Free Derry, http://www.museumoffreederry.org/content/12-14-august.

1.11. Poster for Northern Ireland Civil Rights Association march on January 30, 1972, including description of planned route from Creggan to Guildhall. Report of the Bloody Sunday Inquiry, Volume II, 474. 
1.12. Map showing several strategic barriers planned by British Army leading up to Bloody Sunday, including those at Little James, Sackville, and William Streets. Principal Conclusions and Overall Assessment of the Bloody Sunday Inquiry, 15.

1.13. Photograph showing marchers gathering in the Creggan area on Bloody Sunday. Report of the Bloody Sunday Inquiry, Volume II, 74.

1.14. Photograph showing Bloody Sunday marchers moving into William Street. Report of the Bloody Sunday Inquiry, Volume II, 74.

1.15. Map showing the original and revised routes for the civil rights march on Bloody Sunday. Principal Conclusions and Overall Assessment of the Bloody Sunday Inquiry, 13.

1.16. Photographs showing marchers and eventual riots near Barrier 14 in William Street. Report of the Bloody Sunday Inquiry, Volume II, 94, 99.

1.17. Map showing the paths of two armored vehicles entering the Bogside on Bloody Sunday. Principal Conclusions and Overall Assessment of the Bloody Sunday Inquiry, 19.

1.18. Photographs showing two armored vehicles entering the Eden Place waste ground and the Rossville Flats car park during Bloody Sunday. Principal Conclusions and Overall Assessment of the Bloody Sunday Inquiry, 20.

1.19. Map showing the first Bloody Sunday casualties in the vicinity of the Rossville Flats car park. Principal Conclusions and Overall Assessment of the Bloody Sunday Inquiry, 23.

1.20. Map showing the rubble barricade erected across Rossville Street. Principal Conclusions and Overall Assessment of the Bloody Sunday Inquiry, 24.

1.21. Aerial photograph of the rubble barricade across Rossville Street. Report of the Bloody Sunday Inquiry, Volume $V, 28$.

1.22. Photographs showing marchers and eventual riots near Barrier 14 in William Street. Report of the Bloody Sunday Inquiry, Volume $V, 30$.

1.23. Map showing the Bloody Sunday casualties in the vicinity of the Rossville Street barricade. Principal Conclusions and Overall Assessment of the Bloody Sunday Inquiry, 25.

1.24. Map showing fatal casualties in Glenfada Park North during Bloody Sunday. Principal Conclusions and Overall Assessment of the Bloody Sunday Inquiry, 26.

1.25. Map showing other injuries in Glenfada Park North during Bloody Sunday. Principal Conclusions and Overall Assessment of the Bloody Sunday Inquiry, 27.

1.26. Map showing the Bloody Sunday casualties near Abbey Park, just past Glenfada Park North. Principal Conclusions and Overall Assessment of the Bloody Sunday Inquiry, 31.

1.27. Map showing the final Bloody Sunday casualties between Joseph Place and Rossville Flats. Principal Conclusions and Overall Assessment of the Bloody Sunday Inquiry, 31. 


\section{Chapter 2:}

Figure

2.1. Photograph showing Free Derry Corner following IRA demolition, 1974. Margo Shea, "“Once again it Happens": Collective Remembrance and Irish Identity in Catholic Derry, Northern Ireland 1896-2008," (Ph.D. Diss., University of Massachusetts Amherst, 2010), 390.

2.2. 1982 photograph showing early Republican graffiti on walls of the Rossville Flats. Digital image. Tony Crowley, 1982, Murals of Northern Ireland Collection, Claremont Colleges Digital Library, Claremont, CA.

http://ccdl.libraries.claremont.edu/cdm/ref/collection/mni/id/580.

2.3. 1981 photograph of a Republican mural in Rossville Flats commemorating Bloody Sunday deaths. Digital image. Tony Crowley, 1981, Murals of Northern Ireland Collection, Claremont Colleges Digital Library, Claremont, CA. http://ccdl.libraries.claremont.edu/cdm/ref/collection/mni/id/583.

2.4. 1982 photograph of a Republican mural in Rossville Flats commemorating the April 1982 shooting death of Stephen McConomy. Digital image. Tony Crowley, 1982, Murals of Northern Ireland Collection, Claremont Colleges Digital Library, Claremont, CA. http://ccdl.libraries.claremont.edu/cdm/ref/collection/mni/id/585.

2.5. 1981 photograph of a Republican mural depicting James Connolly and Patrick Pearse, leaders during the failed 1916 Easter Rebellion. Digital Image. Tony Crowley, 1981, Murals of Northern Ireland Collection, Claremont Colleges Digital Library, Claremont, CA. http://ccdl.libraries.claremont.edu/cdm/ref/collection/mni/id/581.

2.6. 1981 photograph of a Republican mural depicting support for ongoing hunger strikes.

Digital image. Tony Crowley, 1981, Murals of Northern Ireland Collection, Claremont Colleges Digital Library, Claremont, CA.

http://ccdl.libraries.claremont.edu/cdm/ref/collection/mni/id/578.

2.7. 1981 photograph of a Republican mural depicting anti-British, anti-Thatcher message and imagery. Digital image. Tony Crowley, 1981, Murals of Northern Ireland Collection, Claremont Colleges Digital Library, Claremont, CA. http://ccdl.libraries.claremont.edu/cdm/ref/collection/mni/id/582.

2.8. 1981 photograph of a Republican mural depicting a paramilitary silhouette alongside the Irish tricolour. Digital image. Tony Crowley, 1981, Murals of Northern Ireland Collection, Claremont Colleges Digital Library, Claremont, CA. http://ccdl.libraries.claremont.edu/cdm/ref/collection/mni/id/592.

2.9. 1981 photograph of a Republican mural depicting an honor roll for deceased local IRA volunteers alongside traditional Gaelic imagery. Digital image. Tony Crowley, 1981, Murals of Northern Ireland Collection, Claremont Colleges Digital Library, Claremont, CA. http://ccdl.libraries.claremont.edu/cdm/ref/collection/mni/id/579. 
2.10. 1983 photograph of a Republican murals/graffiti at Glenfada Park showing support for the IRA alongside anti-police messages. Digital image. Tony Crowley, 1983, Murals of Northern Ireland Collection, Claremont Colleges Digital Library, Claremont CA. http://ccdl.libraries.claremont.edu/cdm/ref/collection/mni/id/602.

2.11. 1983 photograph of a Republican mural on Westland St. depicting support for the political demands of imprisoned hunger strikers. Digital image. Tony Crowley, 1983, Murals of Northern Ireland Collection, Claremont Colleges Digital Library, Claremont CA. http://ccdl.libraries.claremont.edu/cdm/ref/collection/mni/id/601.

2.12. 1995 photograph of a Republican mural on Foyle Rd. depicting threatening imagery directed at the RUC. Digital image. Tony Crowley, 1995, Murals of Northern Ireland Collection, Claremont Colleges Digital Library, Claremont CA. http://ccdl.libraries.claremont.edu/cdm/ref/collection/mni/id/3981.

2.13. 1996 photograph of a Republican mural in Glenfada Park depicting sustained republican mistreatment at the hands of the RUC. Digital image. Tony Crowley, 1996, Murals of Northern Ireland Collection, Claremont Colleges Digital Library, Claremont CA. http://ccdl.libraries.claremont.edu/cdm/ref/collection/mni/id/3744.

2.14. 1994 photograph of a Republican mural on Fahan St. commemorating the Battle of the Bogside. Digital image. Tony Crowley, 1994, Murals of Northern Ireland Collection, Claremont Colleges Digital Library, Claremont CA. http://ccdl.libraries.claremont.edu/cdm/ref/collection/mni/id/3749.

2.15. 1996 photograph of a Republican mural in Glenfada Park protesting the continued antagonism of annual loyalist marches. Digital image. Tony Crowley, 1996, Murals of Northern Ireland Collection, Claremont Colleges Digital Library, Claremont CA. http://ccdl.libraries.claremont.edu/cdm/ref/collection/mni/id/3746.

2.16. 2010 photographs of Republican murals along Lecky Rd. and in Glenfada Park depicting solidarity with Palestine. Digital image. Tony Crowley, 2010, Murals of Northern Ireland Collection, Claremont Colleges Digital Library, Claremont CA. http://ccdl.libraries.claremont.edu/cdm/ref/collection/mni/id/928, http://ccdl.libraries.claremont.edu/cdm/ref/collection/mni/id/845.

2.17. Photograph of the Loyalist "King Billy" mural within the Fountain neighborhood, August 2016. Photo taken by author.

2.18. Photograph showing the Loyalist "No Surrender" mural within the Fountain neighborhood, circa 1987. Bill Rolston, Politics and Painting: Murals and Conflict in Northern Ireland, (Rutherford, NJ: Fairleigh Dickinson University Press, 1991), 43.

2.19. Photograph showing the Loyalist "No Surrender" mural within the Fountain neighborhood, circa 2000. Digital image. Tony Crowley, 2000, Murals of Northern Ireland Collection, Claremont Colleges Digital Library, Claremont CA. http://ccdl.libraries.claremont.edu/cdm/ref/collection/mni/id/4013.

2.20. Photograph showing the Loyalist "No Surrender" mural within the Fountain neighborhood, 
circa August 2016. Photo taken by author.

2.21. Loyalist mural in the Fountain commemorating the Relief of Derry during the siege of the city in 1689, August 2016. Photo taken by author.

2.22. Loyalist mural in the Waterside commemorating the Protestant victory during the Siege of Derry in 1689, August 2016. Photo taken by author.

2.23. Loyalist mural in the Waterside commemorating the role of the Apprentice Boys in the Protestant victory during the Siege of Derry in 1689, August 2016. Photo taken by author.

2.24. Loyalist mural in the Waterside depicting the crest of the Ulster Defence Union, August 2016. Photo taken by author.

2.25. Loyalist commemorative mural in the Fountain depicting the crest of the Ulster Defence Association, August 2016. Photo taken by author.

2.26. Loyalist mural in the Waterside depicting violent paramilitary imagery directed toward the Bogside, along with the crests of the Ulster Defence Association and Ulster Freedom Fighters, August 2016. Photo taken by author.

2.27. Loyalist mural in the Fountain depicting the Red Hand of Ulster, along with acronym reference to West Bank Loyalist Youth; August 2016. Photo taken by author.

2.28. Loyalist mural in the Waterside depicting George Washington, along with reference to his willingness to defend his Ulster-Scot heritage in Virginia; August 2016. Photo taken by author.

2.29. Loyalist mural in the Waterside commemorating historic community organizations; August 2016. Photo taken by author.

2.30. Loyalist mural in the Waterside commemorating the City of Londonderry Temperance Lodge and Glendermott Cricket Club; August 2016. Photo taken by author.

2.31. Loyalist mural in the Waterside commemorating a local victim of paramilitary violence during the Troubles; August 2016. Photo taken by author.

2.32. "The Petrol Bomber" and "Bernadette," People's Gallery murals commemorating events during the Battle of the Bogside, alongside Free Derry Corner; August 2016. Photo taken by author.

2.33. "Death of Innocence" and "Bloody Sunday," People's Gallery murals commemorating the 1971 death of Annette McGavigan and Bloody Sunday (1972); August 2016. Photo taken by author.

2.34. "Motorman" and "The Runner," People's Gallery murals depicting Operation Motorman (1972) and the use of CS gas during Bogside riots; August 2016. Photo taken by author.

2.35. "The Rioter" and "Civil Rights," People's Gallery murals depicting rioting during the Troubles and commemorating key individuals of the Northern Irish civil rights movement during the 1960s; August 2016. Photo taken by author.

2.36. "Hunger Strike" and "Tribute to John Hume," People's Gallery murals commemorating hunger strikers and depicting civil rights leader John Hume alongside fellow Nobel Peace Prize Winners Martin Luther King Jr., Mother Teresa, and Nelson Mandela; August 2016. 
Photo taken by author.

2.37. “The Bloody Sunday Commemoration," People's Gallery mural memorializing Bogside residents killed on Bloody Sunday; August 2016. Photo taken by author.

2.38. "The Peace Mural," culmination of the People's Gallery, within the urban context of the Bogside; August 2016. Photo taken by author.

2.39. "Women of Ireland" mural commemorating the historical contributions by women to the Republican struggle, Gartan Square, Bogside; August 2016. Photo taken by author.

2.40. "Spirit of Freedom" mural commemorating the 30th anniversary of the 1981 hunger strikes, Westland St., Bogside; August 2016. Photo taken by author.

2.41. Bogside mural commemorating the 40th anniversary of the death of Che Guevara; August 2016. Photo taken by author.

2.42. Free Derry Corner altered to show solidarity with international political movements. From top left: LGBT Pride (2007), Ferguson/Black Lives Matter (2014), Syrian migrant crisis and far-right backlash (2015), Rojava Revolution (Jan. 2017). Murals of Derry (Derry: Guildhall Press, 2016), 61, 64, 63 \& Derry Now, https://www.derrynow.com/news/newmural-showing-solidarity-rojava-unveiled-free-derry-corner/142611.

2.43. Composite map showing spatial relationships the Battle of the Bogside (1969), Bloody Sunday (1972), and sites of prominent Republican political murals in the Bogside. Base map taken from Report of the Tribunal appointed to inquire into the events on Sunday, 30th January 1972 [Widgery Report], http://cain.ulst.ac.uk/hmso/widgery1.htm. Mapping information added by author based on Russell Stetler, Battle of the Bogside; Principal Conclusions and Overall Assessment of the Bloody Sunday Inquiry; and collected mural photographs and research.

2.44. Comparison of early political artwork (1983) and current People's Gallery murals (August 2016) at Glenfada Park, facing Rossville Street (First image: Digital image. Tony Crowley, 1983, Murals of Northern Ireland Collection, Claremont Colleges Digital Library, Claremont CA. http://ccdl.libraries.claremont.edu/cdm/ref/collection/mni/id/602; Second image: Photo taken by author)

2.45. 1996 photograph showing republican political graffiti painted on Derry's historic city walls. Digital image. Tony Crowley, 1996, Murals of Northern Ireland Collection, Claremont Colleges Digital Library, Claremont CA. http://ccdl.libraries.claremont.edu/cdm/ref/collection/mni/id/3737.

2.46. Photographs showing examples of paramilitary and other organizational graffiti within the Bogside; August 2016. Photos taken by author.

2.47. Photographs showing examples of everyday urban elements within the Bogside painted to resemble the Irish tricolour; August 2016. Photos taken by author.

2.48. Photographs showing examples of graffiti within the Bogside expressing threats and animosity toward the local police force; August 2016. Photos taken by author. 
2.49. Photographs showing examples of anti-drug/paramilitary graffiti within the Bogside; August 2016. Photos taken by author.

2.50. Photographs showing examples of political graffiti related to injustice and imprisonment within the Bogside; August 2016. Photos taken by author.

2.51. Photographs showing an attempt to paint over potentially controversial political graffiti within the Bogside; August 2016. Photos taken by author.

2.52. Photographs depicting political ephemera within the Bogside related to radical organizations and anti-police attitudes; August 2016. Photos taken by author.

2.53. Photograph showing political posters for anarchist and workers' socialist political groups within the Bogside; August 2016. Photo taken by author.

2.54. Photograph showing IRA recruitment signboard within the Bogside; August 2016. Photo taken by author.

2.55. Photograph showing "Brits Out Now - IRA" signboard mounted beneath an Irish tricolour flag within the Bogside; August 2016. Photo taken by author.

2.56. Photograph showing a Starry Plough flag, a variation of the Irish tricolour, and an Easter Rebellion commemorative flag being flown within the Bogside; August 2016. Photo taken by author.

2.57. Photograph showing a Cuban flag depicting Che Guevara being flown within the Bogside; August 2016. Photo taken by author.

2.58. Photographs showing loyalist paramilitary graffiti within the Waterside neighborhood; August 2016. Photos taken by author.

2.59. Photographs showing the prevalence of British flags and similarly colored painting schemes in the Fountain and Waterside areas; August 2016. Photos taken by author.

2.60. Photographs showing colored banners being flown over a roadway and a detailed view of curbstone painting in the Waterside neighborhood; August 2016. Photos taken by author.

\section{Conclusion:}

Figure

3.1. Photograph of Bogside bonfire during construction, with Lecky Rd. flyover behind; August 15, 2016. Photo taken by author.

3.2. Photograph of Bogside bonfire showing RUC cutout mounted to front; August 15, 2016. Photo taken by author.

3.3. Photograph of the Bogside bonfire showing attached political posters and flags, view from Derry city walls; August 15, 2016. Photo taken by author.

3.4. Photograph of Bogside bonfire showing Sinn Fein political posters; August 15, 2016. Derry Journal, https://twitter.com/derryjournal/status/765501330114879488?lang=en.

3.5. Photograph of the Bogside bonfire ablaze, view from Derry city walls; August 15, 2016. Photo taken by author. 
3.6. Aftermath of the Bogside bonfire, morning of August 16, 2016. Photo taken by author.

3.7. Aftermath of the Bogside bonfire, showing scarring and discoloration of roadway; August 17, 2016. Photo taken by author.

3.8. Aftermath of the Bogside bonfire, showing graffiti and damage to adjacent warehouse building; August 17, 2016. Photos taken by author. 


\section{Acknowledgements}

I would first like to thank my committee members, Sheila Crane, Christa Robbins, and Shiqiao Li for their continued support and insight throughout this process. Our conversations have been integral to the development of this thesis and to my future research interests. I am also hugely grateful to the University of Virginia School of Architecture and the Department of Architectural History for the thesis research grants that allowed me to travel to Belfast and Derry, Northern Ireland in August 2016. The ability to see and experience the contested spaces and symbolic landscapes of both cities in proved invaluable in shaping the aims of this research and providing an entirely unique body of evidence that would have otherwise remained unrecoverable.

Finally, I owe a special thanks to my parents, Alex and Leisa Walker, for their lifelong encouragement and support of my pursuits. 
Introduction

The signing of the Good Friday Agreement in Belfast on April 10, 1998, brought a tentative end to three decades of ethno-political violence and unrest in Northern Ireland - a period widely known as "the Troubles." Rooted in a centuries-long history of ethno-religious division and segregation dating back to the implementation of Protestant sovereignty over the region by Oliver Cromwell in 1649, tensions escalated following the emergence of a Catholic civil rights movement in the mid-1960s calling for an end to discrimination by majorityProtestant governments and police in Northern Irish cities. As protest marches and demonstrations became more frequent, political unrest led to anxiety among both local police and the city's Loyalist communities, with the violent suppression of an October 5, 1968 protest in the city of Derry by the Royalist Ulster Constabulary often viewed as a critical tipping point in the early years of the conflict. By the end of the decade, the civil rights movement had evolved into a violent conflict over the constitutional status of Northern Ireland, with Irish Republicans increasingly calling for independence from the United Kingdom and a reunification with the Republic of Ireland. Interface areas between ethnically-divided neighborhoods became highly charged spaces of potential violence, and Northern Irish cities were quickly divided and reoriented by the widespread construction of barricades and "peace walls" that served to further enforce dynamics of segregation and incite feelings of hostility. Following several years of sectarian clashes and bombings, the formation of the Provisional IRA in 1971 set in motion decades of terrorism, violent reciprocities, and guerilla warfare between competing paramilitary groups and British armed forces that would result in over 3,500 casualties and leave indelible physical and psychological scars on the cities of Northern Ireland. 
While undeniably rooted in a long history of segregation, discrimination, and unrest, the events of the Troubles constitute a decidedly urban phenomenon. As such, Northern Irish cities served as active spatial settings continually reframed by demonstration and protest, violent confrontation and suppression, and ephemeral tactics ultimately aimed at forcing the collapse of the government of Northern Ireland and the withdrawal of British armed forces. Urban spaces became subject to militarization, occupation, and oscillating territorial claims both permanently destructive and ephemeral, all framed by intertwining dynamics of sectarian strife, physical segregation, and colonialist authority. This thesis aims to unpack and explore the complex spatial practices and phenomena that served to dramatically reshape and reorient Northern Irish cities during the Troubles. While offering an extensive foundational basis, previous scholarship has tended to focus largely on the historical, socio-cultural, and political aspects and costs underlying the conflict, with very little attention paid to examining the relationship between urban conflict and the creation of symbolic spaces and landscapes.

The city of Derry served as an epicenter for several defining events during the early years of the conflict, from the emergence of the civil rights movements in the mid-1960s to moments of full-blown urban conflict in the late 1960s and early 1970s. Given this historic significance, Derry presents a substantive site of inquiry for an examination of the relationship between conflict and symbolic urban space. In particular, this thesis will focus predominantly on the city's Bogside neighborhood, a Catholic community which held a great deal of symbolic significance in the early events of the Troubles and has remained a site of sectarian tension and Republican identity well into the present day.

The thesis is structured both thematically and chronologically, with its two main thematic concerns largely reflecting the evolving nature of the Troubles in Derry. The first chapter focuses 
on two defining early events of the conflict in the city - the Battle of the Bogside in 1969 and Bloody Sunday in 1972. Using a combination of historical accounts and official government reports, this chapter offers a more focused and intensive spatial analysis of these two events, with particular attention given to the role of the built environment in shaping and reflecting contestations between police and military authority and residents of the Bogside. These two events are further situated within the broader context of political upheaval and urban redevelopment that defined Derry from the mid-1960s through the mid-1970s in an effort to fully elucidate the precarious nature of everyday life and urban space within the Bogside during the early years of the Troubles. The second chapter traces the integral role of this spatial history in shaping the more symbolic tactics that have largely come to define the conflict in Derry from the early 1980s up to the present day. Focusing on the city's iconic political murals as well as a broader matrix of ephemeral objects and practices within the urban environment, this chapter illustrates how many of the same urban spaces upended by violence and conflict during the early years of the conflict would again become battlegrounds in a new war of political images and ephemera. Building on the historical and iconographic narratives of previous scholars, this examination of political murals and ephemeral tactics aims to situate both within a more rigorous spatial and iconological analysis of the contested urban landscape. Finally, the conclusion draws from my own on-site experiences in the Bogside in an effort to frame these two narratives of contested urban space with an eye toward the future.

While scholarship that examines issues of conflict and urban space in Northern Ireland is relatively scarce, several historical sources have been integral in attempting to reconstruct a spatial history of key events in Derry during the early years of the Troubles. Russell Stetler's The Battle of Bogside: The Politics of Violence in Northern Ireland offers perhaps the most 
comprehensive account of the events of August 1969 in Derry, culminating in a thoroughly detailed description of the three-day confrontation known as the Battle of the Bogside. Published just over a year after the events described, Stetler's argument focuses predominantly on ethical issues surrounding the deployment of CS gas in the Bogside during the struggle, rather than its impacts on the built environment. However, the rigor and contemporary nature of his account provides a vital foundation for reexamining the Battle of the Bogside as a spatial phenomenon. Niall Ó Dochartaigh's From Civil Rights to Armalites offers further supplementary information on the Battle of the Bogside while situating it more completely within the broader transition from the civil rights movement to armed conflict taking place in Derry during the late 1960s.

Similarly, while a great deal of scholarship has been devoted to the events of Bloody Sunday in 1972, much of this work has focused on the moral and symbolic questions surrounding the use of excessive and indiscriminate force by British soldiers rather than any detailed spatial information. Unsurprisingly, even official histories of Bloody Sunday have been embattled by conflict. The first official British government report on the event, produced by the Widgery Tribunal and published only eleven weeks after Bloody Sunday in April 1972, defended accounts by British soldiers that individuals within the Bogside had been firing weapons and handling explosives, warranting the use of lethal force. While accepted at the time by Northern Ireland's Loyalist government, the conclusions of the Widgery Tribunal deeply angered Derry's Catholic community, which viewed the report as whitewashing the killing of innocent civilians by the British army.

Given the long-standing controversy surrounding Bloody Sunday and its aftermath, a new tribunal was established in 1998 to compile a definitive version of events, with the subsequent official report published in 2010. Known as the Saville Inquiry, this second report acknowledged 
that British soldiers had indeed fired first and found no evidence of firearms or explosives being used by Bogside residents, effectively exonerating the victims of Bloody Sunday and confirming what Derry's Catholic community had long believed. This report, which consists of thousands of pages of photographs, maps, diagrams, and police and witness testimony surrounding Bloody Sunday, offers another foundational source for reconstructing the spatial history of one of the defining moments of the Troubles. Like Stetler's account of the Battle of the Bogside, the Saville Inquiry is predominantly aimed at answering questions of British military force and ethics rather than providing an architectural or urban account of Bloody Sunday. However, given the exhaustive nature of the maps, diagrams, and photographs compiled, the report represents the most comprehensive and objective account of Bloody Sunday, making it vital to research surrounding the spatial impacts of the event.

Scholarship and detailed mapping information pertaining to the urban form and development of Derry before and during the Troubles is also uncommon, with the one notable exception being Margo Shea’s recent dissertation ““Once again it happens': Collective Remembrance and Irish Identity in Catholic Derry, Northern Ireland 1896-2008." In her work, Shea provides an extensive examination of memory, identity, and place within the Bogside and other Catholic communities in Derry, collecting decades of newspaper articles, local publications, and resident testimonies to craft a historical narrative of a continuously evolving city. While lacking in visual information such as historic maps, photographs, or architectural drawings, Shea's research offers a significant account of the broad urban redevelopment strategies that were implemented in the Bogside from the mid-1960s into the mid-1970s. As Shea argues, ongoing policies of urban renewal within the Bogside had a significant impact on the way residents came to view the neighborhood and its community, further upending spaces of 
everyday life in an urban area already facing significant political upheaval. As such, Shea's research provides an important parallel narrative of urban change and spatial crisis during the late 1960s and early 1970s that is pivotal to fully understanding the precarious nature of everyday urban space in the Bogside during this period.

In an effort to construct a more rigorous spatial analysis of these key events and concurrent urban strategies during the early years of the Troubles in Derry, this thesis will draw primarily from theoretical strategies employed in Eyal Weizman's Hollow Land and other writings. While Weizman's work traces the history of architectural and urban strategies in the context of the Israeli-Palestinian conflict, its critical methodologies offer an important and highly transposable model for assessing the active role of the built environment in contemporary urban conflict. In particular, his discussion of Israeli Defense Force tactics of "walking through walls" and inverting the normal order and geometry of everyday urban space offers a unique critical language for discussing the concurrent dynamics of urban renewal, police suppression, and collective resistance that characterized the Bogside from 1966 to $1972 .{ }^{1}$

In reassessing the role of Derry's political murals as dynamic spatial objects, it is important to acknowledge the work of several scholars who have examined and analyzed the wall paintings for their evolving iconographic content as well as their role in conveying political messages and asserting territorial claims. In particular, Bill Rolston's extensive work since the 1990s in cataloguing and analyzing the imagery of murals across Northern Ireland offers a strong foundation for understanding the murals of Derry and historical shifts in their iconographic content over time. Similarly, Neil Jarman's writings on the murals and other visual displays in Northern Irish cities are integral to this research, with his 1998 essay "Painting Landscapes: The Place of Murals in the Symbolic Construction of Urban Space" offering a critical first effort at

\footnotetext{
${ }^{1}$ Eyal Weizman, Hollow Land: Israel's Architecture of Occupation (London: Verso, 2007): 185.
} 
understanding the role of political murals as "activated facets" within the broader urban landscape. ${ }^{2}$ Essays by Gregory Goalwin and Tony Crowley offer further information regarding the evolution of political imagery in the murals of Northern Ireland. Additionally, Crowley's extensive photographic archive of murals across Northern Ireland since the 1980s, hosted by the Claremont Colleges Digital Library, provides a wholly unique source of early images from the walls of Derry that were vital to this research.

In addition to contextualizing Derry's political murals within the contested spatial history and symbolic landscape of the city, this thesis aims to consider them within a broader collection of ephemeral urban tactics that includes graffiti and paramilitary tagging, political posters and stickers, flags, and other urban artifacts. Scholarship on the utilization of such tactics in the Northern Irish context is virtually nonexistent, with flags and other political paraphernalia largely confined only to brief mentions in writings on political murals. In addition, historical materials that do exist are often removed from their original urban context, presenting a considerable difficulty in analyzing their role in spatial and territorial contestations within the urban environment. For example, the Linen Hall Library's Troubled Images collection, which comprises over 3,000 images of political posters and other ephemera from the conflict, offers an exhaustive archive of visual materials with very little information related to their actual relationship to urban space. As such, while undoubtedly a valuable archival resource as well as a potentially fruitful path for future investigations, such material is ultimately no longer recoverable given its removal from a highly specific spatial context. In an effort to begin reconciling the exorbitant and inherently fleeting nature of urban ephemera with the stated aims

\footnotetext{
${ }^{2}$ Neil Jarman, "Painting Landscapes: The Place of Murals in the Symbolic Construction of Urban Space," in Symbols in Northern Ireland, ed. Anthony Buckley (Belfast: Institute of Irish Studies, 1998) Accessed February 27, 2017. http://cain.ulst.ac.uk/bibdbs/murals/jarman.htm\#chap5
} 
of this research, this thesis will focus primarily on ephemeral materials observed and catalogued through on-site fieldwork in Derry conducted during August 2016.

The works of Henri Lefebvre will serve as the primary critical framework for understanding how political murals and ephemera have continually contributed to the creation of differentiated spaces within the contested city of Derry. Lefebvre's theories on the formative role of ephemera as tools of collective mobilization and spatial appropriation will be useful in analyzing both ephemeral tactics and political murals within the broader urban landscape, as well as in examining their ability to transform and invest sites with a multiplicity of continually shifting functions and meanings.

Ultimately, while the years since the Good Friday Agreement have seen the peace process tentatively move towards diffusing sectarian tensions in Derry and throughout Northern Ireland, the impacts of the Troubles remain deeply embedded and symbolically present in the everyday spaces of the city. Nowhere is this more visible than in the Bogside, where collective memory of the early events of the conflict and a lasting legacy of political murals and ephemeral tactics continue to shape the significance of the urban landscape. While police and paramilitary violence have largely disappeared and the once dynamic gable walls of the neighborhood have slowly solidified into a more stable commemorative landscape, latent political tensions continue to manifest themselves along the city's walls and streets - sometimes in volatile fashion. As a result, understanding the complex spatial history of conflict and contestation in Derry remains vital not only to the city itself moving forward, but also to more fully understanding the considerable impacts of violent conflict, systemic inequality, and sustained precarity in contemporary cities. 


\section{Chapter 1: Urban Events and Upheaval in "Free Derry" \\ "The Bogside in Derry was a street. Now it is a condition." 3 \\ - Seamus Deane, "Why Bogside?” (1971)}

By the mid-1960s, the city of Derry was plagued by a wide array of social and economic problems, with Catholic communities in particular facing high unemployment, hiring discrimination, housing shortages, and overcrowding. These problems were only compounded by the fact that long-standing practices of political gerrymandering had left these communities with disproportionately low representation in all areas of local government, leaving Derry's Catholic citizens with almost no say in how to go about addressing their concerns. In particular, housing would become a crucial focal point during the 1960s, with many viewing it as a direct byproduct and embodiment of the myriad social, political, and economic inequalities underlying life in Derry. Addressing the housing crisis was thus viewed as a critical first step in challenging the broader political and social structure of the city. ${ }^{4}$

Urban renewal offered one solution to the problems facing the Catholic community. A 1959 study produced by the Housing and Rent Restriction Act of Northern Ireland had indicated that roughly $40 \%$ of the housing stock in Derry was unfit. ${ }^{5}$ By 1966 , hundreds of dwellings in the Bogside and surrounding areas had been condemned and scheduled for demolition. ${ }^{6}$ In an effort to address the increasingly urgent housing shortages, a preliminary plan was introduced for a fourteen-story housing estate in the Bogside - a proposal that was wholly incongruous with the existing built fabric of the area. ${ }^{7}$ With few other options for new construction in the area,

\footnotetext{
${ }^{3}$ Seamus Deane, "Why Bogside," Honest Ulsterman 27 (1971): 1.

${ }^{4}$ Margo Shea, "“Once again it happens": Collective Remembrance and Irish Identity in Catholic Derry, Northern Ireland 1896-2008." (Ph.D. Diss., University of Massachusetts Amherst, 2010): 318.

${ }_{6}^{5}$ Ibid., 299.

${ }^{6}$ Ibid., 302.

${ }^{7}$ Ibid.
} 
nationalist members of the city council reluctantly supported the proposal. Despite some initial pushback from residents, by 1966, the proposal had morphed into a redevelopment plan for three multi-story flats to be built on Rossville Street, on the former grounds of a local cattle market. ${ }^{8}$ Known as the Rossville Flats, this housing complex would quickly gain extraordinary significance within a built environment on the brink of being thrust into physical and political upheaval.

Grassroots initiatives surrounding housing issues also played a critical role in the Bogside during the mid-1960s. In 1965, local clergyman Father Anthony Mulvey founded the Derry Housing Aid Society, a volunteer organization dedicated to offering advice on improving housing conditions for the city's impoverished residents. ${ }^{9}$ By 1966, members of the Housing Aid Society had founded the Derry Housing Association, which undertook the task of interviewing local families about housing conditions and even funding and constructing a complex of thirtytwo housing units in the Pennyburn area of the city. ${ }^{10}$ However, more extensive building plans by the DHA were rejected by the city council. Furthermore, a March 1968 report by a Belfast architectural and planning firm indicated that approximately 5,000 substandard houses still remained in Derry and the surrounding area, while estimating that 9,600 new dwellings would be required by 1981 in order to meet the stipulations of the Housing and Rent Restriction Act. ${ }^{11}$

By 1968, residents in Derry had become increasingly frustrated with the ineffectiveness of local politics. Inspired by protest and civil rights movements taking place across the globe, many felt the need for more direct action in addressing their concerns. In March, the Derry Housing Action Committee was formed with the clear intent of more publicly and intensely

\footnotetext{
${ }^{8}$ Shea, 303 .

${ }^{9}$ Ibid., 305.

${ }^{10}$ Ibid., 305-307.

${ }^{11}$ Ibid., 309.
} 
demanding solutions to the city's housing problems. ${ }^{12}$ After achieving little success through repeated attempts to disrupt local meetings dealing with housing, the DHAC quickly took to the streets to voice their concerns. One early incident involved the case of John Wilson, a local man who had been living with his wife and two children in an 18-foot, one-room caravan for three years and had been given no chance at receiving adequate housing by the local government. On June 22, in response to Wilson's situation, ten people from the DHAC moved the caravan into a busy intersection along Lecky Road, effectively blocking a major thoroughfare into the Bogside and other Catholic neighborhoods for nearly three hours. ${ }^{13}$ The caravan was moved following assurances that Wilson's case would receive proper attention. It was returned to the intersection a week later following a lack of substantive action by the city council. ${ }^{14}$ In July, the committee organized a sit-down protest during the opening ceremony for the lower deck of the Craigavon Bridge, during which six DHAC members were arrested. ${ }^{15}$ Following this small protest, activists from the group contacted the Northern Ireland Civil Rights Association about sponsoring a civil rights march in Derry. Scheduled for October 5, 1968, the march was aimed at addressing the numerous complaints of the Catholic community, from the urgent housing situation and job discrimination to the political gerrymandering that allowed the status quo in Derry to persist. ${ }^{16}$ The march was contentious from its conception, and it was banned by the Minister for Home Affairs over concerns that its route would pass Protestant and unionist residences. ${ }^{17}$ As Shea

\footnotetext{
${ }^{12}$ Shea, 311.

${ }^{13}$ Ibid., 312 .

${ }^{14}$ Ibid., 313.

${ }^{15}$ Ibid., 316.

${ }^{16}$ Ibid., 316-7.

${ }^{17}$ Ibid. 319-20.
} 
notes, however, bans on Catholic demonstrations were a familiar and long-standing tactic for suppressing dissent, and organizers had planned to walk regardless. ${ }^{18}$

Between 600 and 2,000 people ultimately defied the ban and congregated at the Craigavon Bridge on October 5, along with 130 police officers and members of the "B Special" reserves accompanied by two water cannons. ${ }^{19}$ When a call came to dispel the marchers, police and reserves "used indiscriminate force," leaving roughly 100 people in need of medical attention by the end of the day. ${ }^{20}$ The march quickly became a defining moment in the early outbreak of the Troubles, and its violent suppression spawned another demonstration of nearly 15,000 people on November 16 . This time, protestors marched successfully from the Waterside into the historic walled city in a moment the Derry Journal heralded as "the end of apathy" in the Derry Catholics' struggle for civil rights. ${ }^{21}$

Ultimately, the issue of adequate housing had become a flashpoint for political action in the Bogside, casting the neighborhood increasingly into political flux by early 1969 . As a first round of urban renewal was reshaping the physical fabric of the area, protests and public demonstrations had begun to activate urban spaces of Derry in new and dramatic ways, as the city's Catholic majority sought to assert its collective right to adequate living conditions and political representation in the face of long-standing inequality. In the early months of 1969 , already heightened tensions would be further exacerbated by more egregious instances of sectarian violence and police suppression, setting the scene for what would become a watershed event for Derry's Catholic community - the Battle of the Bogside.

\footnotetext{
${ }^{18}$ Shea, 320.

${ }^{19}$ Ibid.

${ }^{20}$ Ibid., 320-21.

${ }^{21}$ Ibid., 331-2.
} 
Battle of the Bogside (August 11-14, 1969)

While the Battle of the Bogside represents a pivotal moment in Derry's urban and spatial history, it was by no means the first significant event of the Troubles within the city. As such, it is important to briefly address how key events leading up to the battle served to shape perceptions and fuel tensions between the city's Catholic population - particularly within the Bogside - and the Royal Ulster Constabulary (RUC). Following the violent police suppression of the civil rights demonstration on October 5, 1968, the Northern Irish civil rights movement gained international attention, with Derry emerging at the forefront of the struggle for the first time. ${ }^{22}$ Subsequently, on January 5, 1969, an organized ambush of civil rights marchers by hundreds of Loyalists and some members of the RUC at Burntollet Bridge led to severe rioting and destruction in the Bogside. ${ }^{23}$ In the midst of these events, Bogside resident John "Caker" Casey scrawled the phrase "You Are Now Entering Free Derry" on a gable wall at the corner of Lecky Road and Fahan Street, demarcating for the first time a clear boundary in the struggle between the Catholic community and the police - Free Derry Corner (Figure 1.1). ${ }^{24}$

On April 19, an effort to march from Burntollet to Altnagelvin (outside Derry) in protest of the January attack and subsequent invasion of the Bogside was thwarted, leading once again to violent sectarian riots at Guildhall Square as well as an RUC barracks in Derry. ${ }^{25}$ During this course of events, RUC members forcibly entered the Bogside home of Samuel Devenney in pursuit of rioters, severely beating Devenney and a neighbor to an extent that led to Devenney's eventual death in July. ${ }^{26}$ In response to increased tensions, a reserve police force in full riot gear

\footnotetext{
${ }^{22}$ Russell Stetler, The Battle of Bogside: The Politics of Violence in Northern Ireland (London: Sheed \& Ward, 1970): 40-41.

${ }^{23}$ Ibid., 46-48.

${ }^{24}$ Ibid., 49.

${ }^{25}$ Ibid., 50-51.

${ }^{26}$ Ibid., 52-53.
} 
was temporarily stationed throughout the Bogside, leading many residents to evacuate until the withdrawal of the RUC was negotiated. ${ }^{27}$ Another round of violent clashes surrounding Protestant marches in July further intensified the situation, sparking significant concerns and preparations surrounding the city's Apprentice Boys commemoration in August.

Commemorating the Protestant victory over the Catholic King James II during the siege of Derry in 1689, the celebratory march had become an accepted annual ritual for both Protestants and Catholics, with many Catholics leaving the city or at least attempting to capitalize on the monetary benefits of the tourist spectacle. Despite high tensions, the festivities began as usual on the night of August 11, with ceremonial bonfires lit within the Protestant enclave of the Fountain. While minor confrontations between Catholic and Protestant crowds within the city walls occurred, no serious incidents took place. ${ }^{28}$ In the early afternoon of August 12, the Apprentice Boys march began along its traditional route down Shipquay Street, a road running alongside the section of the Derry's historic city walls overlooking the Bogside. The main area of tension, however, was Waterloo Place, a large intersection where two main Bogside streets - William and Waterloo - flow into the town's commercial district (Figure 1.2). In anticipation, authorities had erected crush barriers comprised of lightweight tubular steel and barbed wire to prevent anyone from entering or leaving the Bogside at these points. The Catholic crowds that assembled behind these barriers were undoubtedly hostile to the marchers, with many angered by the perceived institutional hypocrisy over allowing Protestant marches while restricting Catholic civil rights demonstrations. The traditional singing of sectarian songs by marchers and Loyalist spectators further exacerbated these tensions. ${ }^{29}$

\footnotetext{
${ }^{27}$ Stetler, 54.

${ }^{28}$ Ibid., 68-70.

${ }^{29}$ Ibid., 71-73.
} 
While initial hostilities were restricted mainly to relatively harmless shouting, Stetler notes that the situation rapidly deteriorated, with Bogside residents behind the barriers at Waterloo Place beginning to throw stones at police and marchers around 3:20 pm. ${ }^{30}$ The RUC line at the intersection made no effort to disperse the Catholic crowds or escalate the situation while the march continued, with many attributing their temporary discipline to the large presence of journalists and television cameras. ${ }^{31}$ However, by the time the parade and accompanying spectators had dispersed roughly two hours later, the Catholic crowd had grown largely out of control. ${ }^{32}$ Meanwhile, more violent confrontations between Bogside residents and the RUC rapidly developed at the nearby intersection of Sackville Street and Little James Street. A lack of media presence meant that police stationed along this junction were far less restrained, ${ }^{33}$ while the situation was further amplified by sectarian clashes between Protestant crowds and Catholic youths. ${ }^{34}$ A petrol bomb was thrown around 3:25 pm, as residents within the Bogside were actively constructing a barricade at the corner of William Street and Rossville Street in anticipation of further conflict. ${ }^{35}$

As confrontations at both sites continued to escalate, Stetler argues that the police began to view their role as one of containment from both sides. On one hand, they feared that the increasingly hostile Bogside residents were planning to invade nearby commercial areas with intentions of looting and destroying local businesses. At the same time, they anticipated that members of the Protestant crowds might seek to penetrate the Bogside for similar purposes. However, multiple independent observers insisted that the Catholic crowds had no such intent,

\footnotetext{
${ }^{30}$ Stetler, 74.

${ }^{31}$ Ibid., $75-76$.

${ }^{32}$ Ibid., 76.

${ }^{33}$ Ibid.

${ }^{34}$ Niall Ó Dochartaigh, From Civil Rights to Armalites: Derry and the Birth of Irish Troubles (Houndmills, Basingstoke, Hampshire; Palgrave/Macmillan, 2005): 105.

${ }^{35}$ Stetler, 76.
} 
noting that the Bogside residents could have overwhelmed the RUC numerically at almost any stage if they had wanted to breach the commercial district. Instead, the Bogside residents saw their own role as one of defending their homes and families against what they believed to be an imminent sectarian invasion of the neighborhood fronted by the RUC. As Stetler notes, many Catholics felt deeply convinced that the events of the day offered a significant opportunity for the police to reassert control over the Bogside following an extended and humiliating period of absence. ${ }^{36}$ Ultimately, the atmosphere surrounding the Bogside on August 12 was one of "tension, recrimination, and abuse" on both sides, with each faction striving to perform their defensive duty using whatever means and force necessary. ${ }^{37}$

By early evening, Bogside residents had further escalated the situation through the increasing utilization of petrol bombs. Police began countering by throwing stones to keep the Bogsiders out of range, with some observers noting that policemen gathered stones on their riot shields as ammunition for Protestant gangs who had joined in the struggle. ${ }^{38}$ The large number of slingshots among these Loyalist groups meant that a considerable number of windows near the front of Bogside were quickly broken. ${ }^{39}$ Finally, as these sectarian skirmishes continued to escalate, the RUC chose to charge forward down William Street behind an armored vehicle, breaking a barricade placed there by Bogside residents and pushing the Catholic youths back into the neighborhood. ${ }^{40}$ By 6:00 pm, the RUC had reached a second barricade - constructed primarily of paving stones and wood planks - at Rossville Street, with many among the Protestant crowd following behind (Figures 1.3-4). ${ }^{41}$

\footnotetext{
${ }^{36}$ Stetler, 77.

${ }^{37}$ Ibid., 78.

${ }^{38}$ Ibid., 79.

${ }^{39}$ Ibid.

${ }^{40}$ Ibid., 80.

${ }^{41}$ Ibid.
} 
At this point, a forceful effort was made to decisively address the worsening situation, with police moving a water cannon into William Street in order to control fires started by petrol bombs. Concurrently, other members of the RUC began a push into Chamberlain Street, where they quickly came under heavy attack from a barrage of missiles thrown from the balconies of the Rossville Flats. This onslaught forced the police to retreat and hold outside of projectile range before eventually drawing further back. By 7:30 pm, the situation in the Bogside was considered grave, with the RUC facing immense hostility from Catholic residents at William and Sackville Streets. Bogsiders dominated the nearby rooftops of the neighborhood, utilizing a steady stream of petrol bombs thrown from these elevated positions to exert relentless pressure on police. $^{42}$

In an effort to regain control of the situation, the RUC made the decision late in the evening to introduce CS gas into the Bogside. The first cartridge, delivered via a cardboard canister roughly 1.25 inches in diameter and 4 inches in length, was fired into the Bogside around five minutes before midnight. ${ }^{43}$ This marked the beginning of a relentless campaign that would eventually see 1,147 units of CS gas fired into the Bogside over the next two days, equating to roughly one canister every two minutes. ${ }^{44}$ As Dochartaigh notes, the Bogside was enveloped with gas during this period, with the irritant covering streets and penetrating houses throughout the neighborhood - including those of residents not initially involved in the conflict (Figure 1.5). ${ }^{45}$

Despite this significant action, the police position on Rossville Street fluctuated minimally over the next forty hours, with any suppressive benefits gained from the CS gas

\footnotetext{
${ }^{42}$ Stetler, 80-81.

${ }^{43}$ Ibid., 84.

${ }^{44}$ Dochartaigh, 107.

${ }^{45}$ Ibid.
} 
invariably checked and negated by constant barrages of petrol bombs from the rooftops of the Rossville Flats. ${ }^{46}$ Police were able to reach and occupy the rooftops of nearby three-story commercial buildings for a period of time, but ultimately never made it within fifty yards of the housing estate. ${ }^{47}$ Groups of roughly thirty youths manned the rooftops of these high flats and were well equipped with petrol bombs, materials for their manufacture, and basic devices for mitigating the effects of CS gas, including wet blankets and water buckets (Figure 1.6). ${ }^{48}$ Meanwhile, first aid stations were established on the ground to address casualties, while women and children began making petrol bombs in the back streets around the high flats (Figure 1.78). ${ }^{49}$ Elsewhere, children were systematically tearing up paving stones for ammunition and transporting them to barricades in wheelbarrows. ${ }^{50}$ Two separate newsletters compiled by the Derry Citizens' Defense Association and the Labour Party began to circulate, reporting on events at the battlefronts and offering instructions for making, storing, and throwing petrol bombs. ${ }^{51}$ Overall, Dochartaigh notes two "academic observers" describing the organization among residents as "largely spontaneous and ad hoc," with influential individuals moving from place to place with advice and instructions in lieu of any centralized coordination efforts (Figure 1.9) ${ }^{52}$ According to these two individuals, the collective sense of being under siege by the RUC had facilitated "something like perfect consensus politics" in the Bogside. ${ }^{53}$ Notably, by the afternoon of August $13^{\text {th }}$, both the Irish tricolour and the Starry Plough - the flag of the Irish

\footnotetext{
${ }^{46}$ Stetler, 86-87.

${ }^{47}$ Ibid.

${ }^{48}$ Ibid., 87.

${ }^{49}$ Dochartaigh, 107.

${ }^{50}$ Ibid.

${ }^{51}$ Ibid., 108.

52 Ibid., 107.

${ }^{53}$ Ibid.
} 
Citizens' Army and a symbol of the workers' republic - were visibly flying from the rooftops of the Rossville Flats (Figure 1.10-11). ${ }^{54}$

By this point on the $13^{\text {th }}$, the battle had peaked in criticality. As Stetler notes, Bogside residents were procuring petrol through every possible means, from purchase and communal collections by women to theft and intimidation. ${ }^{55}$ Bathtubs full of petrol were seen in the Bogside, and petrol bombs were being manufactured with speed and efficiency. ${ }^{56}$ Residents had devised other defensive instruments as well, including wooden planks studded with nails and steel cylinders fitted with spikes (known as "spiders") to disable armored vehicles. ${ }^{57}$

Additionally, a fire hydrant was opened in an effort to dampen down CS gas throughout the neighborhood. ${ }^{58}$ Severe escalation was also threatened on multiple occasions. That afternoon, six men occupied the gas works on Lecky Road, threatening to shut it off unless the RUC ended the use of CS gas in the Bogside. ${ }^{59}$ In a separate incident, a group of Catholic residents also surrounded and threatened an RUC barracks near Creggan in an hours-long siege that lasted until a truce was negotiated around 9:30 in the evening. ${ }^{60}$

Significant confrontations continued throughout the evening of August $13^{\text {th }}$. A large factory on Little James Street had been set on fire, as had a barricade at the intersection of Great James Street and Francis Street. ${ }^{61}$ Police had been driven back toward William Street, with the Bogsiders' continued advancement toward the intersection with Chamberlain Street rekindling

\footnotetext{
${ }^{54}$ Stetler, 93.

${ }^{55}$ Ibid., 90.

${ }^{56}$ Ibid.

${ }^{57}$ Ibid.

${ }^{58}$ Ibid.

${ }^{59}$ Ibid., 91.

${ }^{60}$ Ibid., 91.

${ }^{61}$ Ibid., 94.
} 
RUC fears of Catholic attempts to invade commercial areas. ${ }^{62}$ During the course of the evening, a televised address by Irish Prime Minister Jack Lynch declared that the RUC could no longer be considered an impartial entity and demanded that the British government intervene and enter into negotiations regarding "the present constitutional position of the six counties of Northern Ireland. ${ }^{63}$ While highly inflammatory at the time, Lynch's remarks are indicative of the immense gravity of the situation that was occurring within the Bogside and serve to foreshadow a critical moment in the history of the Troubles in Derry.

Around 5:00 pm on the afternoon of the $14^{\text {th }}$, three hundred British troops from the Prince of Wales Own Regiment arrived at Waterloo Place to relieve the RUC. ${ }^{64}$ Upon assuming control of the situation, the army agreed not to enter the Bogside, which had been bracing for the renewed prospect of invasion by a mobilized group of B-Specials - a Protestant quasi-police force - only an hour earlier. ${ }^{65}$ As a result, the barricades that had taken on considerable physical and symbolic importance during the battle remained in place, and the confrontation was temporarily ended ${ }^{66}$ Significantly, as Dochartaigh argues, the events of the past three days had also served as a pivotal moment in shifting the political views of more moderate Catholics in the Bogside toward the Republican cause, with many viewing the RUC's aggression and use of CS gas as a full realization of previous fears regarding invasion and attacks on the community. ${ }^{67}$

An undeniably urban event, the Battle of the Bogside offers a critical case study for examining and analyzing the spatial practices and phenomena associated with Derry during the Troubles. In particular, it is important to consider the events that took place in relation to broader

\footnotetext{
${ }^{62}$ Stetler, 94.

${ }^{63}$ Ibid., 95.

${ }^{64}$ Ibid., 97.

${ }^{65}$ Ibid., 96-97.

${ }^{66}$ Ibid., 97.

${ }^{67}$ Dochartaigh, 106.
} 
changes taking place within the urban environment at the time. As Shea notes, the Bogside was essentially a "building site" in 1969, with derelict and boarded up houses still standing immediately adjacent to the newly constructed Rossville Flats and "tidy maisonettes" built between 1966 and $1968 .{ }^{68}$ Bricks, stones, cement, and other materials left over from construction and demolition work had already frequently been co-opted as sources of ammunition for Bogside rioters, encapsulating the nature of a neighborhood in both political and architectural flux. ${ }^{69}$

The further utilization of rubble, bricks, paving stones, and any other available detritus in the construction of barricades represents what Eyal Weizman calls an "inversion of the urban syntax," with elements of circulation, demolition, and change being recast as elements of stasis and defense by Bogside residents. ${ }^{70}$ Weizman introduces this concept in his discussion of tactical maneuvers in urban environments, citing French revolutionary Louis-Auguste Blanqui's belief in barricades as "elements employed for the protection of self-governing urban enclaves." "In this vein, through the resourceful and coordinated construction of informal barricades and other obstacles to impede police movement and vehicular access, residents within the Bogside reappropriated the materials of urban erasure and renewal in the creation of an alternative built language characterized by urgency and necessity.

Similar dynamics of subversion and re-appropriation can also be read at the scale of the neighborhood. As Shea notes, urban renewal in Derry during the mid-1960s was only the beginning of a larger process that eventually came to utilize architectural and planning elements that supported police surveillance and facilitated the control of movement into and out of the

\footnotetext{
${ }^{68}$ Shea, 371.

${ }^{69}$ Ibid.

${ }^{70}$ Eyal Weizman, “Lethal Theory,” Log, no. 7 (2006): 66.

${ }^{71}$ Ibid.
} 
Bogside and other Catholic neighborhoods. ${ }^{72}$ While no such intent has been explicitly ascribed to the construction of the Rossville Flats during this period, such modernist mass housing projects have frequently been implemented as structures of legibility and containment in both European settings and colonial contexts. ${ }^{73}$ As such, the ability of Bogside residents to utilize the architectural affordances of the high flats as a primary bastion of defense represents a significant act of spatial appropriation and collective subversion of the built environment. Furthermore, the Bogsiders' intimate knowledge of the more traditional built fabric of the neighborhood allowed them opportunities to move and congregate in alleyways and back streets, facilitating the ad-hoc mobilization of residents in a number of distinct capacities. Continuing his discussion of historical urban warfare tactics, Weizman notes, "The fight in the city, and for the city, was equated with its interpretation." ${ }^{74}$ In this sense, the Bogside residents' ability to rapidly interpret and tactically utilize the built environment transformed the urban fabric from a locus of conflict into the "medium and very apparatus" of urban warfare in Derry. ${ }^{75}$

Bloody Sunday (January 30, 1972)

Despite initial relief at the arrival of British troops in the Bogside, a large portion of the Catholic community had turned against the army by the beginning of 1972, with many viewing holding them alongside the RUC as agents of a repressive regime. A large part of the Bogside remained a "no-go" area dominated by a resurgent IRA and devoid of ordinary policing, while much of the area lay in ruins due to ongoing riotous behavior by the IRA and Catholic youths. Armed violence had led to a number of casualties among civilians, soldiers, policemen, and IRA

\footnotetext{
72 Shea, 373.

${ }^{73}$ See Sheila Crane, "Rewriting the Battles of Algiers: Ephemeral Tactics in the City at War," Space and Culture 18, no. 4 (November 2015) for an examination of this phenomenon in French Algeria.

${ }^{74}$ Weizman, "Lethal Theory," 66.

${ }^{75}$ Ibid.
} 
members. In August 1971, the Northern Irish government had introduced the highly controversial policy of internment without trial for suspected terrorists and paramilitary members. The policy allowed the British army to arrest, detain, and interrogate anyone suspected of ties to terrorist activities, with Catholic men often being "lifted" during house searches conducted between 3:00 a.m. and 5:00 a.m. ${ }^{76}$

Additionally, a new ban had been placed on marches and processions in an effort to reduce violence and prevent sectarian confrontations. By January 1972, the Northern Ireland Civil Rights Association had decided to defy this ban and began planning a protest march against internment in Derry. The proposed route would begin in the Creggan area and proceed through the Bogside into Guildhall Square, where prominent individuals would address the crowd gathered (Figure 1.12). ${ }^{77}$

In response to this plan, authorities developed a strategy that would allow the march to take place within the Nationalist area of the Bogside, but would prevent it from reaching the Guildhall through the erection of tactical barriers (Figure 1.13). ${ }^{78}$ In addition, provisional plans were developed to suppress riots expected to follow the demonstration and potentially even arrest prominent members of the IRA youth wing, known as the Fianna Éireann or "Derry Young Hooligans," who were considered a major factor in continued unrest and destruction in the city. ${ }^{79}$ In order to facilitate this potential operation, the $1^{\text {st }}$ Battalion, Parachute Regiment (1 PARA) was ordered to travel from their station outside Belfast to Derry, arriving in the city on the morning of Sunday, January $30{ }^{80}$ The events that followed that day would come to be widely known as

\footnotetext{
${ }^{76}$ Shea, 361.

${ }^{77}$ Principal Conclusions and Overall Assessment of the Bloody Sunday Inquiry, 7-8.

${ }^{78}$ Ibid., 8.

${ }^{79}$ Ibid.

${ }^{80}$ Ibid.
} 
Bloody Sunday, marking perhaps the defining event of the Troubles and representing "a microcosm, a symbol of what Britain does in Ireland."

Comprised of many thousands of marchers, the civil rights demonstration began in the Creggan area before making its way circuitously through the Bogside and into William Street (Figures 1.14-15). ${ }^{82}$ Organizers had learned of the army's plans to prevent the march from reaching the Guildhall and had subsequently altered its route, choosing instead to redirect marchers down Rossville Street and toward Free Derry Corner for public speeches (Figure 1.16). ${ }^{83}$ However, as marchers reached the intersection of William Street and Rossville Street, many ignored the revised plan and instead continued along William Street toward the army barrier erected there (Barrier 14). Riots quickly broke out along this barrier as well as those blocking Little James Street (Barrier 12) and Sackville Street (Barrier 13), with marchers throwing stones and other missiles at soldiers (Figure 1.17). Soldiers responded with the use of rubber bullets before subsequently deploying CS gas at Barrier 12 and a water cannon at Barrier 14 in an attempt to disperse rioters. ${ }^{84}$

Around this time, soldiers stationed in a derelict building on William Street fired five shots into the street below, wounding two men. Minutes later, an order was given for one company of the 1 PARA unit to begin an arrest operation by breaching Barrier 14 and proceeding into William Street. In addition, and without proper authority, another order was given to deploy a company of soldiers in two armed vehicles through Barrier 12 and into Little James Street. The first of these vehicles proceeded down Rossville Street before turning into the waste ground at Eden Place, while the second continued forward before reaching the Rossville

\footnotetext{
${ }^{81}$ Graham Dawson, "Trauma, Place and the Politics of Memory: Bloody Sunday, Derry, 1972-2004," History Workshop Journal, no. 59 (2005): 153.

${ }^{82}$ Principal Conclusions and Overall Assessment of the Bloody Sunday Inquiry, 12.

${ }^{83}$ Ibid.

${ }^{84}$ Ibid., 14.
} 
Flats car park, unintentionally striking two civilians on the way (Figure 1.18). As soldiers disembarked from their vehicles, they now stood just beyond the Rossville Flats complex that had been so pivotal during the Battle of the Bogside. Chaos rapidly ensued, with many civilians in the area of Eden Place and the car park immediately running for cover as soldiers left their vehicles (Figure 1.19). ${ }^{85}$

The first casualties in the Bogside came after soldiers opened fire in the Rossville Flats car park, mortally wounding one man and hitting four other civilians (Figure 1.20). Meanwhile, vehicles carrying two more platoons had followed the original units into the Bogside, with another platoon disembarking in Rossville Street and making their way to the low walls of a ramp at the Kells Walk flats. Upon reaching this ramp, soldiers opened fire in the direction of a rubble barricade running across Rossville Street toward Glenfada Park North (Figure 1.21-22). Initial shots mortally wounded one man, who was carried away from the barricade by several others. Soldiers in Rossville Street continued firing on the barricade shortly after, mortally wounding five more civilians and injuring a man - Alexander Nash - who had run to the barricade to tend to his son, William (Figure 1.23). As the events in Rossville Street were ongoing, a group of four soldiers moved from the low walls at Kells Walk into the residential complex at Glenfada Park North and opened fire almost immediately, mortally wounding two men and injuring a further four (Figure 1.24-25). One of these solders then continued on into the nearby residential complex of Abbey Park, where he shot and mortally wounded a further two men (Figure 1.26). Others who had been in Glenfada Park North moved back toward Rossville Street, ultimately killing one man, mortally wounding another, and injuring two more (Figure 1.27). ${ }^{86}$

\footnotetext{
${ }^{85}$ Principal Conclusions and Overall Assessment of the Bloody Sunday Inquiry, 15-21.

${ }^{86}$ Ibid., 22-30.
} 
Only ten minutes had elapsed between the entrance of armed vehicles into the Bogside and the final shootings in Rossville Street. ${ }^{87}$ However, the events had seen the everyday spaces of the Bogside transformed instantly into sites of tragedy and atrocity, with visual and forensic evidence and hundreds of civilian eyewitness testimonies indicating that soldiers had opened fire on unarmed citizens without provocation. ${ }^{88}$ Among those civilians were individuals "who were running or crawling away, lying wounded on the ground, waving handkerchiefs as white flags, and going to the aid of the wounded and dying." 89

In assessing the spatial aspects of Bloody Sunday, it is useful to again consider the broader nature of urban transformation and upheaval facing the Bogside at the time. Concurrent with the escalation of the Troubles was an increase in the implementation of urban renewal strategies in the Bogside and surrounding areas. Processes of urban redevelopment were initially met with support from Bogside residents, with many viewing the demolition of unfit and outdated housing as tantamount to the destruction of "an oppressive political universe" in which they had long been held. ${ }^{90}$ As the conflict evolved, however, redevelopment plans began to increasingly utilize architectural and planning elements that supported surveillance and facilitated the control of movement into and out of the neighborhoods. ${ }^{91}$ While an explicit relationship between the desires of the police and British forces and the implementation of certain planning schemes has yet to be made public, Shea argues that a reading of how the

\footnotetext{
${ }^{87}$ Principal Conclusions and Overall Assessment of the Bloody Sunday Inquiry, 31.

${ }^{88}$ Dawson, 161.

${ }^{89}$ Ibid.

${ }^{90}$ Shea, 372.

${ }^{91}$ Ibid., 373.
} 
cityscape evolved during this period indicates that security concerns were integral to redevelopment planning considerations. ${ }^{92}$

During the early 1970s, nearly 15,000 residents of the Bogside and Creggan neighborhoods were relocated to housing estates a few miles from the urban core of Derry. ${ }^{93}$ Additionally, urban redevelopment saw significant destruction of houses, streets, and squares throughout the Catholic communities, replacing these spaces with architectural and urban elements that were decidedly more legible and easily defensible for police and the British army. These concerns reflected the growing volatility of the situation in Derry - a situation made all the more problematic by the emergence of paramilitary organizations throughout the city. By late 1969 , many of these organizations had obtained the funding, weapons, and support required to become self-sustaining. The provisional wing of the Irish Republican Army (PIRA) broke away from the Official IRA during this period, with the latter dissolving completely in 1972. Additionally, Loyalist paramilitary groups began to gain prominence as well; the Ulster Volunteer Force (UVF), which had formed in 1966, had become a significant entity by 1969, while the Ulster Defence Association (UDA) emerged in $1971 .{ }^{94}$

In addition to more aggressive policing tactics, Shea asserts that "defensible space" strategies such as lower population densities, larger open spaces, increased visibility, strategic positioning of public buildings, erasure of alleyways, and construction of wider roadways, flyovers, and cul-de-sacs were utilized throughout Derry as a means of making the Catholic neighborhoods more legible and defensible. ${ }^{95}$ Lower population densities meant that public demonstrations and protests became easier to quell simply by restricting access into the Bogside,

\footnotetext{
${ }^{92}$ Shea, 374.

${ }^{93}$ Ibid., 341.

${ }^{94}$ Ibid., 360 .

${ }^{95}$ Ibid., 376.
} 
while curfews, checkpoints, and house-to-house patrols became easier to manage. ${ }^{96}$ Notably, houses lining the steep hillside leading from the historic city walls down into the heart of the Bogside were demolished, with the resulting space left entirely vacant in order to enable unimpeded views of the Bogside for soldiers stationed at patrol bases along the city walls. ${ }^{97}$ In addition, a new four-lane roadway was developed running adjacent to the Rossville Flats and travelling directly through "Free Derry Corner." The fifty-yard width of the roadway meant that barricades like those frequently used from 1969 to 1972 would be impossible to construct, while also facilitating access for armored vehicles. Additionally, the construction of a fly-over roadway in 1973 further divided Catholic neighborhoods from the center of the Bogside. ${ }^{98}$

On a broader level, the frequent utilization of cul-de-sacs in redevelopment projects, while billed as fostering the creation of micro-communities, ensured that police and military vehicles could more easily block streets within the Bogside, while other architectural features limited the number of potential escape routes between houses. ${ }^{99}$ The relative absence of trees increased the visibility and legibility within the urban landscape, while uniform architectural designs, lack of dense alleyways, and brighter streetlights all served to make it much more difficult to move unseen through the built environment. Ultimately, notions of legibility useful to planners doubled as strategies for supporting security tactics aimed at the containment and suppression of unrest as well as anti-terrorism operations and widespread surveillance. ${ }^{100}$ In this sense, the broad campaign of urban redevelopment and renewal in Derry's Catholic communities had replaced a locally legible landscape with universally legible one. ${ }^{101}$

\footnotetext{
${ }^{96}$ Shea, 376-77.

${ }^{97}$ Ibid., 377.

${ }^{98}$ Ibid., 378.

${ }^{99}$ Ibid., 380.

${ }^{100}$ Ibid., 381.

${ }^{101}$ Ibid., 382.
} 
Along with echoing the ongoing physical transformation of the Bogside during the early 1970s, the events of Bloody Sunday serve to encapsulate the growing invasion of the neighborhood's private domain facilitated by more aggressive policing, surveillance, and search tactics. As previously noted, intimate knowledge of the traditional urban landscape had served as an early asset for Bogside protestors, with individuals fleeing from police often able to rely on the open front doors of their neighbors as an avenue of escape into back yards and dense, meandering alleyways. This "geography of neighborliness" reflected long-standing local customs within Catholic communities, though it was not without considerable repercussions. As the 1969 incident involving the police beating of Samuel Devenney illustrates, it did not take long for the burgeoning conflict to penetrate the private realm. With the introduction of internment in 1971, house searches and arrests became increasingly prevalent - incursions that amounted to a "profound form of trauma and humiliation" for affected residents. ${ }^{102}$ In his discussion of Israeli Defense Force tactics for covertly moving through Palestinian mass-housing strucutures, Weizman notes that such invasions of private space by mechanisms of conflict obliterate "functional spatial syntax," with previously held notions of "private" and "public" fundamentally disrupted. ${ }^{103}$ Just as the physical landscape of the Bogside was being made more legible and defensible by the forces of urban renewal, the conceptual landscape of the neighborhood was being upended as well, with everyday life growing increasingly precarious. As the private and public realms within the Bogside were increasingly blurred, house and city became indistinguishable, with the conceptual destruction of domestic walls exposing the private domain of everyday life more than ever to the forces of political power.

\footnotetext{
102 Weizman, "Lethal Theory," 58.

${ }^{103}$ Ibid., 75.
} 
In this sense, parallels can be drawn between the destabilization of the private realm and the larger upending of spatial sovereignty in the Bogside as a whole during this period. Returning to his discussion of IDF tactics of "walking through walls" in order to move through domestic strucutures, Weizman argues that domestic walls and city walls serve similar roles at different scales, with each demarcating clear separations between entities. ${ }^{104}$ Domestic walls, he asserts, embody values of democracy, while city walls embody the broader sovereignty of political entities within. While Derry's city walls had historically served to exclude the Catholic community from the city's core, the series of informal barricades that had persisted since the Battle of the Bogside served to delineate a new perception of sovereignty for the residents of "Free Derry." The crush barriers constructed by British forces leading up to Bloody Sunday reflect this dynamic. While the Bogside's rubble barricades created a "no-go area" for police and military patrols, the more formal barriers aimed at keeping the marching population from entering Derry’s traditional symbolic center.

As such, the violent incursion of British troops into the Bogside on Bloody Sunday represents already established tactics of upending fundamental spatial relationships writ large. Just as internment had fundamentally disrupted the private domain within Catholic Derry, the unjustified invasion and atrocity of Bloody Sunday transgressed and thoroughly obliterated broader conceptions of sovereignty and security in the Bogside. Urban renewal practices played a role in the event as well, having directly led to the creation of larger open spaces such as the Rossville Flats car park in which many of the Bogside casualties were wounded or killed. Unlike the Battle of the Bogside, which saw Bogside residents subvert urban redevelopment in defense of their community, the ability of armored vehicles and British forces to rapidly enter and move

\footnotetext{
${ }^{104}$ Weizman, "Lethal Theory," 74-5.
} 
freely through the built environment on Bloody Sunday reflects a perverse success for the “defensible space" schemes concurrently reshaping the neighborhood's physical fabric.

Derry would become a more pronounced battleground in the immediate aftermath of Bloody Sunday, with the IRA stepping up bombing campaigns against the physical fabric of the city. The Guildhall, one of the city's most famous historic structures, was nearly destroyed by a series of bombs in 1972. As Shea notes, a 1974 report on the situation in Derry found that 124 businesses had been destroyed by attacks, with an additional 1,809 premises sustaining some level of damage. ${ }^{105}$ Physical violence associated with the Troubles increased dramatically as well; by the end of 1972, 476 people had been killed as a result of the conflict, as opposed to 171 in 1971 and 26 in $1970 .{ }^{106}$ As the Provisional IRA gained traction in Derry, efforts by authorities to contain activities and detain members escalated, with house-to-house searches, curfews, and overall increased scrutiny becoming an increasingly normal part of everyday life for residents in Catholic neighborhoods. In particular, Operation Motorman in 1972 saw the destruction of all remaining barricades within the Bogside in an effort to retake the "no-go" area and establish a more regular military presence, effectively marking the end of "Free Derry."

Ultimately, the Battle of the Bogside and Bloody Sunday represent pivotal urban events within a broader trajectory of architectural and political upheaval in Derry from the mid-1960s through the early 1970s. While political conflict and urban redevelopment would continue in the years and decades that followed, the period between 1969 and 1972 encapsulates the most cataclysmic shifts in the physical and political landscape of the Bogside. As urban redevelopment cast the city's more permanent built fabric into continual flux, a series of key

\footnotetext{
105 Shea, 369.

${ }^{106}$ Ibid., 368.
} 
spatial events upended the conceptual landscape of everyday life within Catholic Derry. These ruptures also spawned an entirely new and ephemeral built language within the Bogside - one in which the detritus of construction and demolition became ad-hoc mechanisms for staking and defending territorial claims for equality, autonomy, and security. As if to reflect the intense upheaval surrounding their conception as well as their central role in the turbulence of the period, the Rossville Flats were slated for demolition by the city council in the mid-1980s, just two decades after their construction. ${ }^{107}$ As Shea notes, the city of Derry had become architecturally and politically unsustainable by the mid-1960s. ${ }^{108}$ However, the interrelated and interdependent processes of urban renewal, civil rights, and political violence that ensued - and the wide array of spatial practices that resulted - would become a foundational part of a unique and devastating history of urban conflict.

With the establishment of regular British military presence and the effective end of "Free Derry" in late 1972, political violence declined significantly throughout the city. Following the disbanding of the Official IRA, the shift by the Provisional IRA toward a terrorist campaign meant that sustained urban conflict in Derry would never again reach the levels seen before 1972. Instead, the sectarian struggle within the Bogside - and throughout Derry as a whole would soon become embodied in a set of more symbolic spatial practices aimed at asserting territorial claims and reinforcing collective identities. In place of rubble barricades, dynamic political murals and a multitude of ephemeral objects would soon come to dominate the urban landscape across Derry, overtaking gable walls and other architectural elements to commemorate historical events, honor paramilitary groups, express political loyalties, and demarcate the borders between Catholic and Protestant enclaves. Such urban elements would ultimately

\footnotetext{
107 Shea, 409.

${ }^{108}$ Ibid., 410.
} 
encompass all aspects of the built environment in Derry, allowing residents to continuously appropriate and reframe urban space using a wide array of expressive spatial practices that persist into the present day. 
Chapter 2: Political Murals, Ephemeral Tactics, and the Symbolic Landscape in Derry

While the combined forces of military policing, paramilitary insurgency, and urban renewal continued to physically and conceptually reshape the urban landscape in Derry during the mid-1970s, a minor conflict emerged over the fate of an early landmark of the Troubles within the Bogside - Free Derry Corner. As part of a transportation redevelopment scheme, plans had been drawn up for the demolition of nearly all of the existing houses along Lecky Road in preparation for a new four-lane roadway linking the Bogside and the Creggan estates. This included the house on which the phrase "You Are Now Entering Free Derry" had first been scrawled in 1969, and on which it had persisted in several forms since. Outcry from neighborhood residents was immediate, with many in the area calling for the house's preservation as a historical monument. As Shea notes, the site had long been a community focal point and gathering place, given its relative centrality to Derry's Catholic neighborhoods. As such, the addition of the "Free Derry" slogan was not the first action to imbue the site with significance. Instead, it served to highlight its historical value while elevating its place within the local political geography. Despite this, disagreements persisted given the derelict state of the houses and the impracticality of their location, with a May 1975 meeting on the matter ending without consensus. Within weeks of the meeting, however, the houses were gone - except for the lone gable wall bearing the famous slogan (Figure 2.1). In an effort to save the Free Derry wall, members of the IRA had performed the demolition themselves, intentionally leaving behind the first of many political murals that would soon become critical within a new set of spatial practices in the city. ${ }^{109}$

${ }^{109}$ Shea, 385-90. 
While the episode surrounding Free Derry Corner reflects the continuing physical upheaval that resulted from urban renewal policies in the Bogside during the 1970s, it also serves as a precursor for a wide array of spatial phenomena that would emerge in Derry in the years that followed. By the start of the 1980s, the rapid emergence and immediate popularity of political murals as a visual tool of the Republican political movement had begun to reshape urban space in new and more dynamic ways. In response, Loyalist movements quickly revived their own historical practices of mural painting and ephemeral display, creating an urban landscape in which a multitude of competing visual media became mechanisms for staking territorial claims, asserting political messages, drumming up local support, and crafting collective identities among residents in Derry's various sectarian enclaves.

While previous scholarship has addressed the symbolic content and political motivations behind Northern Ireland's political murals, this chapter aims to build on this work and reconsider their role as functional architectural objects situated within a broader symbolic landscape of sustained precarity. Utilizing Henri Lefebvre's work on ephemera and the city, this analysis will go on to reposition these murals within a wider lexicon of dynamic and performative spatial tactics and expressive actions that have served to continually reshape and transgress the urban landscape in Derry up to the present day. Given the inherent transience of much of the material examined, this analysis will draw from on-site observations and fieldwork conducted during August 2016 in an effort to construct a more complete narrative of symbolic spatial practice in the contemporary city.

Even before the Troubles, mural painting was not without historical precedent in Northern Ireland, though the practice had been almost entirely one-sided before the 1980s. Loyalist murals have a legacy dating back as far as 1908, with Protestant communities 
traditionally painting walls to coincide with annual marches commemorating the Protestant victory over Catholicism at the Battle of the Boyne on July $12,1690 .{ }^{110}$ These early murals represented only part of a multitude of cultural ephemera associated with celebrations of The Twelfth, including banners, bunting, and arches as well as the traditional drumming, singing, and festivities of the parade itself. While this connection to a traditional Loyalist holiday made the murals an important expression of collective identity and culture, their very presence also served to highlight the long-standing political dominance of the Protestant cause, as both the British government and the Parliament of Northern Ireland often banned similar displays by nationalist communities. ${ }^{111}$ As such, the prevalence of Loyalist murals and celebrations coupled with institutionalized intolerance for Republican cultural symbols served to reinforce the political and cultural status quo in Northern Ireland. ${ }^{112}$ However, for much of their history, Loyalist murals were not a sustained part of the urban landscape. Instead, their deployment typically remained limited to celebrations of the Twelfth, similar parades, and other cultural events until their rapid proliferation in the 1980 s. $^{113}$

In contrast, Republican murals were an entirely new phenomenon upon their emergence during this period. The initial impetus for the explosion of nationalist murals was the 1981 hunger strikes, during which groups of Republican prisoners led by Bobby Sands protested the British government for recognition as political prisoners along with the rights that accompanied that status. While political graffiti had first emerged following Sands' 1979 call for "a massive Paint and Poster campaign" in support of the prisoners, the death of Sands and ten other hunger

\footnotetext{
${ }^{110}$ Gregory Goalwin, “The Art of War: Instability, Insecurity, and Ideological Imagery in Northern Ireland's Political Murals, 1979-1998," International Journal of Politics, Culture, and Society 26, no. 3 (May 31, 2013): 197.

${ }^{111}$ Ibid., 198.

${ }^{112}$ Ibid.

${ }^{113}$ Ibid.
} 
strikers in 1981 became the catalyst for a remarkable surge in full-blown mural painting as a show of resistance to British and Loyalist dominance. ${ }^{114}$

As Goalwin notes, Republican muralists primarily aimed to emphasize the human impacts of the struggle while highlighting the nationalist community's long-standing oppression by the Loyalist groups and the British government. ${ }^{115}$ As such, the content of Republican murals often focused on more recent events, with many paintings framing the current struggle within a broader narrative of resistance to Loyalist and British forces. In doing so, muralists sought to justify the emergence of paramilitary groups and other political organizations that claimed to be fighting for civil rights and protecting Catholic communities. Ultimately, Goalwin argues that Republican murals typically fall into five main themes that include depictions of hunger strikers and other Republican martyrs; memorials to victims of the conflict; solidarity with international revolutionary and civil rights movements; symbols of identity such as flags, crests, and coats of arms; and representations of paramilitary groups and armed conflict. ${ }^{116}$

Historical images show that many of the early murals painted in the Bogside reflected these common symbols and themes while also drawing from more localized events and contexts. For example, an early piece of political graffiti written on the walls of the Rossville Flats reads “H.M. [Her Majesty's] Prison Rossville," likely criticizing both the excessive state of British military policing within the Bogside as well as the very nature of the high flats themselves, which can be read as structures of containment in their own right (Figure 2.2). One early mural from the Rossville Flats lists the names of the thirteen individuals killed on Bloody Sunday alongside a memorial cross, while another memorializes the death of Stephen McConomy, a young boy killed in April 1982 by a plastic bullet fired by British soldiers under the auspices of

\footnotetext{
${ }^{114}$ Goalwin, 198-99.

${ }^{115}$ Ibid., 205.

${ }^{116}$ Ibid., 205-6.
} 
maintaining civil order (Figures 2.3-4). ${ }^{117}$ In both cases, the memorialization of innocent victims of the conflict serves as both a remembrance of those lost to the struggle as well as an emotional appeal for support to those still fighting. ${ }^{118}$ A mural from 1981 shows James Connolly and Patrick Pearse, two Republican leaders from the failed 1916 rebellion known as the Easter Rising commonly used by muralists in an effort to draw a clear lineage between past and present in the struggle for Irish freedom (Figure 2.5). ${ }^{119}$ Still others present common imagery of hunger strikers as Christ-like martyrs, anti-British messages, paramilitary figures alongside the Irish tricolour, and memorials for paramilitary members killed in action (Figures 2.6-9). Early murals were certainly not limited to the Rossville Flats, with historic photographs from the Glenfada Park estate and Westland Street showing murals and political graffiti featuring political demands, support for the hunger strikes and the IRA, and resentment toward police (Figures 2.10-11).

More recent images indicate the persistence of these themes in Derry's Republican murals while also illustrating an increasing solidarity with international resistance movements. A number of photographs from the mid-1990s show murals expressing continued distrust and even threats of violence toward the RUC (Figures 2.12-13). Another from Fahan Street in 1994 commemorates the Battle of the Bogside using Gaelic-style imagery common to Republican wall paintings, while a 1996 mural from Glenfada Park protests the continuation of often antagonistic Loyalist marches without the consent of nationalist communities (Figures 2.14-15). This more formal message is notably underscored by more hastily scrawled and aggressive graffiti in support of the IRA, another common visual element within the Bogside. More recent photographs from the late 2000s depict murals showing support for the Palestinian struggle against Israel, a message of solidarity that has appeared continually in Republican murals as far

${ }^{117}$ Goalwin, 208.

${ }^{118}$ Ibid.

${ }^{119}$ Ibid., 207. 
back as 1982 (Figure 2.16). ${ }^{120}$ That same year, Rolston notes, also saw the first documented occurrence of the flying of Palestinian flags in Northern Ireland, at the Rossville Flats. ${ }^{121}$

In response to the explosive rise of Republican murals in the early 1980s, Loyalist communities revived and expanded their own mural tradition, with muralists adopting a visual language aimed at asserting territoriality and reflecting the historical dominance of Protestant culture and politics. While Republican murals are notable for the consistent presence of a diverse array of themes, Goalwin notes that Loyalist murals show a progression of predominant themes and symbols over time. ${ }^{122}$ He argues that depictions of historical events dominated Loyalist murals in the early 1980s, before a shift toward more explicitly threatening images of paramilitary groups during the middle of the decade. ${ }^{123}$ Rolston directly attributes this shift toward more militaristic content to the signing of the Anglo-Irish Agreement in November 1985, which granted the Republic of Ireland marginal influence in the political affairs of the North. ${ }^{124}$ Viewed by unionists as a major blow to the established political order, the agreement resulted in a rise in militant loyalism, with paramilitary groups preparing to defend against "the final sellout of Ulster." ${ }^{\prime 25}$ The overt violence represented in such murals thus served as a mechanism for inscribing boundaries onto the urban landscape of Derry while also implying harsh retribution for those who transgressed them. ${ }^{126}$ By the mid-1990s, this more violent imagery had been partially supplanted by the use of paramilitary crests, flags, and coats of arms, though more hostile depictions often still remained. Rolston argues that this thematic progression reflects

\footnotetext{
${ }^{120}$ Bill Rolston, “"The Brothers on the Walls': International Solidarity and Irish Political Murals," Journal of Black Studies 39, no. 3 (April 13, 2007): 461.

${ }^{121}$ Ibid.

${ }^{122}$ Goalwin, 199-200.

${ }^{123}$ Ibid., 200.

${ }^{124}$ Bill Rolston, Politics and Painting: Murals and Conflict in Northern Ireland (Rutherford, N.J.: Fairleigh Dickinson University Press, 1991): 43.

${ }^{125}$ Ibid.

${ }^{126}$ Goalwin, 202.
} 
continually shifting concerns over "the ultimate raison d'être of loyalism" - defense. ${ }^{127}$ In his view, the sustained militancy of Loyalist murals reflects an underlying conviction that any incremental gains achieved by Republican movements inherently represent a loss for Protestant hegemony. ${ }^{128}$ As such, the heavy use of paramilitary imagery served as a reassurance to Loyalist communities that defeat had not been conceded.

Much like the city's Republican murals, Derry's Loyalist artwork is largely representative of the common themes and visual elements used throughout Northern Irish cities and towns. One of the city's most enduring Loyalist murals, located in the Protestant neighborhood of the Fountain, depicts "King Billy," or William III of England, whose victory at the Battle of the Boyne in 1690 serves as a foundational moment in Loyalist history (Figure 2.17). As Goalwin notes, "King Billy" represents the single most popular image in Loyalist murals, given his direct relationship to the ascendency and historical dominance of Protestant culture in the North. ${ }^{129}$ Another long-standing mural within the Fountain consists only of a black background bearing the words "Londonderry West Bank Loyalists Still Under Siege - No Surrender." Historical photographs show that this particular image has persisted in multiple forms since at least the mid-1980s, and its imposing presence continues to delineate the entrance to the enclave in the present day (Figure 2.18-20).

Depictions of other historical events remain common in both the Fountain and the Loyalist neighborhood on the Waterside, with murals commemorating elements of the Protestant victory during the Siege of Derry present in both communities (Figure 2.21-23). Paramilitary crests are also widely prevalent, though more violent Loyalist imagery largely seems to have

${ }^{127}$ Bill Rolston, "Changing the Political Landscape: Murals and Transition in Northern Ireland." Irish Studies Review 11, no. 1 (April 2003): 8.

${ }^{128}$ Ibid.

${ }^{129}$ Goalwin, 200. 
disappeared within Derry (Figure 2.24-25). One notable exception is a menacing painting in the Waterside depicting a skeleton in Loyalist paramilitary garb marching away from a decimated Bogside, with Free Derry Corner clearly show in ruins (Figure 2.26). The Red Hand of Ulster, which frequently figures in Loyalist paramilitary crests, is also a common visual element in its own right, symbolizing a willingness on the part of Loyalist groups to "fight on, whatever the cost" (Figure 2.27). ${ }^{130}$ A more recent theme to emerge in the Loyalist murals of the Waterside is the commemoration of the unique role of Ulster-Scots in the founding of America. As Rolston notes, nearly 350,000 Ulster-Scots (or Scotch-Irish) immigrated to the United States during the $18^{\text {th }}$ century, beginning a cultural lineage that would produce a number of key figures in American history. ${ }^{131}$ In acknowledgement of this shared cultural heritage, Loyalist murals depicting George Washington and Teddy Roosevelt have both appeared in Derry, with the latter still standing in the Waterside (Figures 2.28). In addition, local figures and historical organizations are also honored in present-day Waterside murals (Figures 2.29-31).

Beginning in the mid-1990s, the Bogside's most prominent murals began to solidify into a more stable series of images depicting key events from the neighborhood's history. Known as the People's Gallery, the sequence of murals along Lecky Road and Rossville Street collectively form a document of key images of the Troubles in Derry, including the civil rights movement of the 1960s, the Battle of the Bogside, the 1971 police shooting death of Annette McGavigan, Bloody Sunday, Operation Motorman, the 1981 hunger strikes, and solidarity with international civil rights figures (Figure 2.32-37). Culminating with the Peace Mural, depicting a dove on a multicolored background, the collection now serves as a major tourist attraction for the city (Figure 2.38). Other contemporary murals just off this main thoroughfare commemorate the

\footnotetext{
${ }^{130}$ Goalwin, 204.

${ }^{131}$ Rolston, "Brothers," 466.
} 
significant role of women in the Republican struggle, the $30^{\text {th }}$ anniversary of the hunger strikes, and the $40^{\text {th }}$ anniversary of the death of Che Guevara (Figures 2.39-41). At the center of this narrative landscape remains Free Derry Corner, which, unlike the more fixed murals surrounding it, remains an active symbolic surface continually used to express solidarity with a wide array of international political causes, including LGBT Pride, Ferguson and Black Lives Matter, the Syrian refugee crisis, and the Rojava Revolution (Figure 2.42).

While an intensive reading of the symbolic content of Derry's competing political murals offers key insights into the complex political landscape of the city, a more expansive and encompassing analysis of the contemporary urban landscape is necessary in order to fully grasp the critical role of ephemeral practices in continually reshaping everyday spaces within it. The work of Neil Jarman offers a foundation on which to base a more rigorous spatial analysis of the political murals. His research offers an initial consideration of the murals not simply as images, but as urban artifacts that gain significance through their site-specificity while simultaneously reframing everyday public spaces as "activated facets" of political struggle. ${ }^{132}$ Just as importantly, he notes that the murals, despite their perceived solidity, continually exist in a state of flux, with new images frequently situated near or painted over older murals to create "a complex stratigraphy of ideological designs.","133

An analytical mapping of political murals within the Bogside in relation to the events of the Battle of the Bogside and Bloody Sunday serves to more fully elucidate ways in which the spatial history of the neighborhood is both deeply embedded and visually present in the activated surfaces created by the murals (Figure 2.43). By visualizing the two events in combination with available information on prominent sites of political artwork, a significant intersection becomes

\footnotetext{
132 Neil Jarman, "Painting Landscapes.”

${ }^{133}$ Ibid.
} 
clear between key spaces of collective memory and performative spatial practices of commemoration and territoriality. For example, the Rossville Flats, a site of both communal resistance and tragedy during the Battle of the Bogside and Bloody Sunday, became a prominent early signboard for a renewed Republican resistance, with both commemorative and more expressly political murals linking together past events and present demands. Similarly, Glenfada Park, which had been subjected to police incursion and lethal violence on Bloody Sunday, became a visual bastion demarcating territorial claims of reciprocal violence by the IRA before evolving to encompass a broader array of images challenging military occupation, police brutality, Loyalist hegemony, and international solidarity. Furthermore, with the gradual solidification of the People's Gallery during the mid-1990s, the proposed route of the Bloody Sunday march along Rossville Street developed from a more dynamic assemblage of images into a singular commemorative procession. Gradually evolving from early murals along Rossville Street, this more static set of images recounts the Bogside's contested history and collective identity through a sequence of murals beginning at Free Derry Corner.

A notable example of this shift in symbolic content can be seen in two photographs of political artwork in Glenfada Park (Figure 2.44). The first, taken in 1983, reflects an attempt to stake territorial claims against police and the British army as well as to elicit community support for the IRA. The second, from August 2016, shows the current People's Gallery imagery commemorating Operation Motorman and the historical use of CS gas in the Bogside during rioting. Taken together, these two images illustrate not only the interdependence of spatial history, collective memory, and ongoing contestations within the symbolic urban landscape of the Bogside, but also the evolving ways in which the community perceives and shapes its identity in relation to contested spaces of everyday life. 
Ultimately, what this more spatial and iconological analysis illustrates is an inextricable link between the spatial history of the Bogside and its unique field of political and territorial signification. Significant sites of violence, occupation, resistance, and tragedy during the early years of the Troubles in Derry have gradually evolved into everyday spaces marked by the presence of activated surfaces tying together spatial memory and community identity with contemporary urban experience. However, despite this visualization and analysis of the inherently urban nature of political murals, the opportunity remains for a more expansive examination of the role of ephemera in continually reshaping urban space in Derry. By broadening the purview of study to encompass not only mural painting, but also graffiti, tagging of urban artifacts, posters, flags, and public demonstrations, it becomes possible to more clearly and comprehensively understand the myriad ways in which residents within Derry's sectarian enclaves utilized affordances within the built environment as a means of symbolically reconstructing urban space. Given the inherent transience of much of this material, this analysis will draw significantly from on-site observations and fieldwork conducted during August 2016 in an effort to construct a more complex narrative of ephemeral spatial practice and experience in the contemporary city.

In his reflections on ephemera and the city, Henri Lefebvre posits the ephemeral as "the complete mobilization, not of the population, but of space." ${ }^{\prime 134}$ In this dynamic, the ephemeral becomes the mechanism by which "every place becomes multifunctional, polyvalent, transfunctional, with an incessant turnover of functions; where groups take control of spaces for expressive actions and constructions, which are soon destroyed." 135 While the Bogside had

\footnotetext{
${ }^{134}$ Henri Lefebvre, The Urban Revolution (Minneapolis: University of Minnesota Press, 2003): 130-131. ${ }^{135}$ Ibid.
} 
become familiar with an array of expressive appropriations of urban space - along with their suppression and destruction - in the previous decades, the emergence of political murals, particularly as a tool of the Republican cause, was unique in its ability to effectively utilize and reframe otherwise mundane elements of the everyday built environment. Early slogans and murals from the walls of the Rossville Flats bear testament to the resourceful appropriation of large, blank walls in supporting the paramilitary cause, memorializing the losses of traumatic urban events, and even criticizing the oppressive nature of the modernist high flats. Just as the architectural rationale of the Rossville Flats had been upended during the Battle of the Bogside, the housing estate was once again an activated battleground in an emerging war of visual media. The rapid dissemination of political murals and graffiti to the similarly bland and featureless gable walls and brick facades of row houses and urban renewal complexes further exemplifies this ability on the part of muralists to appropriate the urban fabric in order to convey political messages and craft collective identities through a diverse lexicon of visual imagery. In several instances during the mid-1990s, muralists even utilized Derry's historic walls to convey political messages, briefly appropriating and recasting the most enduring bastion of Protestant hegemony in the city - as well as the site of an RUC station and observation tower - in the name of Republican resistance (Figure 2.45).

Despite the increasingly static nature of political murals in Derry during the ongoing peace process, the contemporary urban landscape remains continually animated by even more transient artifacts and practices, not least of which is graffiti. While Republican muralists utilized the relatively mundane wall surfaces afforded by the Bogside's built fabric, a walk through the present-day neighborhood reveals a nearly indiscriminate use of available architectural and infrastructural elements. While the Lecky Road and Rossville Street thoroughfare remains fairly 
unscathed, paramilitary acronyms become almost immediately unavoidable upon entering secondary streets. Hastily scrawled initials for the IRA, INLA, and Bogside Republican Youth (BRY) are noticeable not only on walls throughout the neighborhood, but also on utility boxes, fence posts, and sheet metal fencing (Figure 2.46). In particular, utility boxes and fence posts are also frequently painted to resemble the Irish tricolour (Figure 2.47). Elsewhere, more aggressive graffiti messages spell out threats and insults aimed at the local police force, as well as a particularly pointed threat towards drug dealers within the community, reflecting a recent shift by some paramilitary groups toward policing the issue (Figure 2.48-9). Other writings express political demands related to justice and release for political prisoners, in continuance with themes addressed in earlier murals (Figure 2.50). In many instances, attempts to paint over and hide graffiti messages leaves only traces behind, though even these texts serve to highlight the persistent, if more latent, dynamism of the urban landscape (Figure 2.51).

Political posters, stickers, and signboards further contribute toward this effect, with smaller visual media consistently present on the lampposts, utility boxes, and walls of the Bogside. Small stickers depicting a hand holding a petrol bomb and advertising the Bogside Republican Youth are commonplace, as are stickers warning that 'People Should Not Inform MI5" - a clear play on the Police Service of Northern Ireland acronym as well as a reflection of continued animosity regarding local interactions with police (Figure 2.52). Less overtly militant political posters for anarchist and socialist workers' movements also appear along walls within the neighborhood (Figure 2.53). Perhaps most notably, a larger recruitment signboard for the IRA stood visibly mounted along a secondary street in the neighborhood, commemorating the centennial anniversary of the 1916 Easter Rebellion with the phrase "Unfinished Revolution Unfinished Business" (Figure 2.54). Depicting a hooded and masked figure pointing a firearm, 
the image was starkly militaristic in relation to the more solemn and commemorative political murals within the enclave. Its more antagonistic message was echoed by a smaller signboard mounted beneath an Irish tricolour at the top of a lamppost near the entrance to the Bogside, which read "Brits Out Now - IRA" (Figure 2.55).

The flying of an array of flags within the Bogside serves as yet another more fleeting mechanism of territoriality within the urban environment. As Goalwin notes, the flying of nationalist flags has historically been an issue of contention in Northern Ireland, with the Flags and Emblems (Display) Act passed by the Northern Irish Parliament in 1954 targeting the display of "provocative emblems" such as the Irish tricolour. ${ }^{136}$ In particular, a defiant 1951 attempt by local political leaders in Derry to march the tricolour into Guildhall Square on St. Patrick's Day had been met with violent police intervention. ${ }^{137}$ As such, early depictions and usage of the flag were an act of particular defiance toward British and Loyalist authorities within the city, and the tricolour quickly became a ubiquitous symbol in Republican political murals. ${ }^{138}$ In the present day, flying of the Irish tricolour is relatively common throughout the Bogside, along with a number of other flags associated with the Republican struggle. Among these other variants are the Starry Plough of the Irish Citizens' Army, a group associated with the 1916 Easter Rebellion, and the orange sunburst flag of Fianna Éreann, the IRA youth wing. In addition, flags commemorating the Easter Rebellion can also be seen, along with variations of the tricolour that feature Gaelic and paramilitary imagery (Figure 2.56). As previously noted, Palestinian flags are often flown in nationalist areas as well, while Cuban flags also appear in solidarity with that country’s communist revolution (Figure 2.57).

\footnotetext{
${ }^{136}$ Goalwin, 203.

${ }^{137}$ Shea, 240-241.

${ }^{138}$ Goalwin, 210.
} 
While not as prevalent or readily visible, ephemeral tactics similar to those utilized in the Bogside can be found in Derry's two main Loyalist communities as well. Paramilitary graffiti is present on walls in both the Fountain and Waterside neighborhoods, though its usage is much more limited (Figures 2.58). This relative lack of graffiti may be influenced by the continued focus on paramilitary imagery in the murals of both areas, rather than a shift toward less militant and more commemorative depictions like those of the People's Gallery. However, other forms of painting and visual display are just as predominant. Just as the Irish tricolour flies over much of the Bogside, the Union Jack is commonplace in both Loyalist areas, reflecting a sustained identification with - and willingness to defend - the "Britishness" of both communities, even if Britain itself has turned away (Figure 2.59). ${ }^{139}$ Additionally, the flag's traditional colors of red, blue, and white also permeate and lay claim to urban space in more unique ways. The painting of curbstones and other urban elements in alternating bands of red, white, and blue is a widespread practice, as is the stringing of similarly colored banners along major roadways (Figures 2.60). In contrast to the Bogside, however, political posters and stickers are largely lacking in both the Fountain and Waterside, perhaps once again reflecting the sustained presence of more political and militaristic material in nearby murals.

Ultimately, by situating Derry's political murals within a more encompassing analysis of symbolic spatial practices within the city, it becomes possible to more comprehensively examine and understand the ways in which such practices have served to continually reshape urban space. More importantly, a closer study of how the combination of lasting commemorative murals and more fleeting tactics continue to operate within the contemporary city - and in particular, the contemporary Bogside - provides critical insight into the new and continual urban flux that surrounds the ongoing peace process. As Lefebvre notes in his discussion of urban form, "The

${ }^{139}$ Goalwin, 204. 
city writes itself on its walls and it its streets. But that writing is never completed." 140 This certainly remains the case within the Bogside. Even as the neighborhood's political murals transition from being defiant and dynamic appropriations of the built environment toward becoming more static reminders of collective memory and identity, new forms of even more transient visual media continue to recast the urban landscape "as a set of affordances, as process of production, as experience and event." ${ }^{\prime 141}$ While the dual forces of urban renewal and traumatic urban conflict served to dramatically upend physical and conceptual spaces of everyday life during the early years of the Troubles, political murals and other symbolic visual and spatial practices have since served to perpetually appropriate, subvert, and transgress these spaces in the decades that followed.

In the case of the Bogside, it may be worthwhile to conclude by speculating on the relatively militant nature of graffiti and other political ephemera within the present-day community. In her discussion of ephemeral tactics during the Algerian war for independence, Sheila Crane posits the sustained and performative utilization of visual media by Algerian residents within French mass housing complexes as creating a "conjectural space" - one in which necessarily fleeting appropriations of everyday space could imagine alternative futures for the city and its residents. ${ }^{142}$ The same can be said for the numerous early political murals that capitalized on the featureless blank walls of the Rossville Flats, Glenfada Park, and much of the Bogside to project vibrant new forms of identity, remembrance, resistance, and projective anticipation for an independent Ireland. However, even as these once dynamic appropriations of

\footnotetext{
${ }^{140}$ Lefebvre, Urban Revolution, 121.

${ }^{141}$ Andrea Mubi Brighenti. "At the Wall: Graffiti Writers, Urban Territoriality, and the Public Domain," Space and Culture 13, no. 3 (April 15, 2010): 317.

${ }^{142}$ Sheila Crane, "Rewriting the Battles of Algiers: Ephemeral Tactics in the City at War," Space and Culture 18, no. 4 (November 2015): 17.
} 
the urban fabric have become increasingly permanent monuments in the nearly two decades since the Good Friday agreement, tensions clearly remain.

As Lefebvre notes, "the urban will never lack an element of repression, which arises from what is hidden within it and the will to keep hidden the dramas, the latent violence, death, and the quotidian." 143 By broadening the purview of analysis beyond political murals and into more ephemeral media and practices, it becomes possible to read in the landscape not only the persisting conflict between the Bogside and external authority moving forward, but also the internal tensions within the community through their myriad expressions in the built landscape. In a 2015 essay, Tony Crowley argues that a pattern of increasingly militant mural imagery has been emerging in recent years across the walls Northern Ireland, a shift he attributes to the "stagnation and near breakdown of the 'peace process." "144 He further asserts that the close study of these evolving images provide greater insight into "social realities that are often obscured by the niceties and imprecisions of other forms of discourse." ${ }^{145}$ Perhaps the same is true in the Bogside today, where, despite the honorable intentions of the People's Gallery and other commemorative murals in providing a unified vision forward from the peace process, the walls and spaces within the neighborhood signal that a more complex political and social reality still persists. Even as concerted efforts have been made across Northern Ireland to remove militant murals and erase antagonistic graffiti, such latent violence and repressed tensions, as Lefebvre suggests, manage to permeate the urban landscape in ways that can be equally transient and dramatic.

\footnotetext{
${ }^{143}$ Lefebvre, Urban Revolution, 120-121.

${ }^{144}$ Tony Crowley, "Hegemonic Shifts: The Latest from the Walls of Northern Ireland," Estudios Irlandeses, no. 10 (January 2015): 71.

${ }^{145}$ Ibid, 75.
} 


\section{Conclusion}

In the early morning hours of August $15^{\text {th }}, 2016$, a small structure comprised mostly of wooden pallets, large tires, and other debris began to appear in the middle of Lecky Road, situated squarely at the bottom of the flyover roadway entering the Bogside. By the afternoon, the stack of pallets had become a tower measuring roughly twenty feet in height and obstructing much of the traffic entering or leaving the flyover (Figure 3.1). Several teenagers manned the construction, with two or three adding additional pallets while another waved a flag from atop the growing structure. On the sidewalk about ten yards away, a small crowd had gathered to cheer on the process, bringing with them a small collection of flags to hang from a nearby fence. Rather than Irish Republican flags, however, these flags were predominantly related to the Loyalist cause, with even the large banner flying from the top of the tower a national flag for Northern Ireland, in lieu of the typical Irish tricolour seen elsewhere in the Bogside. While highly unusual, the presence of these Loyalist emblems was quickly explained as one young man affixed a large, cartoonish cutout of an RUC vehicle to the front of the tower (Figure 3.2). These items were not being honored or celebrated in any sincere way - they were about to be destroyed. Affixed to the rapidly growing tower at the entrance to the Bogside, these flags that had become so integral to territorial contestations in Derry were about to become part of a highly controversial public demonstration - a massive public bonfire commemorating both the feast day of the Assumption of Mary as well as the Battle of the Bogside.

By early evening, the tower had grown to a height nearly eclipsing that of an adjacent building, with the wooden pallets now almost entirely covered in flags, political posters, and other signs and cutouts (Figure 3.3). Particularly notable alongside the various Loyalist flags and signage were political posters for representatives of Sinn Fein - the longtime political ally of 
Irish Republicanism and the IRA (Figure 3.4). As the crowd surrounding the structure began to grow, a group of police officers began to congregate along the historic city walls, no more than a few yards from the former site of the police headquarters and observation tower that had once overlooked the Bogside. Below the walls, a group of young girls walked past, gleefully singing lines from a Republican sectarian song: "If you stay British soldiers, if you stay, you'll never ever beat the IRA!" Their voices were soon replaced by a set of similar songs emanating loudly from speakers somewhere below in the Bogside. Following the end of a nearby football match, a large wave of supporters filed down the streets of the Bogside and into the vicinity of bonfire. Around 10:20pm, a small secondary bonfire comprised of loose wood, metal objects, and other debris was lit. By 11:15pm, the main tower was ablaze as well, with two young men scaling the tower to douse it in petrol while others hurled petrol bombs. ${ }^{146}$ The spectacle was greeted by celebratory singing and chanting from the crowd of roughly 2,000 people (Figure 3.5$).{ }^{147}$

By the morning of August 16, the towering bonfire was reduced to a smoldering pile of debris (Figure 3.6). By the afternoon, it had been completely scrubbed from the roadway, with scarring and slight discolorations on the asphalt its only remaining trace (Figure 3.7 ). What did remain, however, was a considerable amount of new political graffiti and ephemera, particularly on the warehouse building most closely adjacent to the site of the bonfire - a building unfortunately bearing a mural that reads “\#DerryHappy” (Figure 3.8). Paramilitary tags and antipolice messages were rampant, as were messages such as "Sinn Fein Sell-Outs" directed at traditional allies of the Republican community. While the event was derided by Derry priest Fr. Michael Canny as the work of "gangs of teenagers," his description of the Bogside during the

\footnotetext{
${ }^{146}$ Eamon Sweeney, “2,000 crowd see Bogside bonfire set alight,” Derry Journal, August 19, $2016,6$. ${ }^{147}$ Ibid.
} 
event carried a very particular historical resonance; the bonfire, he argued, had transformed the neighborhood into "a virtual no-go area.",148

The events and aftermath of the Bogside bonfire read as an encapsulation of the Bogside's complex spatial, architectural, material, and symbolic history. Sited directly at the foot of the flyover roadway that had divided the Bogside from other Catholic neighborhoods during the early 1970s, the tower's crude materiality echoed the rubble and debris barricades that once demarcated "Free Derry." Its obstructive location and scale share a common lineage with the derelict caravan of John Wilson, which had twice been moved by the Derry Housing Action Committee to block a nearby intersection in June 1968. In addition, the choice of such a centrally visible site had been heavily influenced by the PSNI's removal of wood and other materials from a disused building in the Bogside just days before, a perceived invasion marked on the bonfire tower by a sign reading "You's Should'nt [sic] Have Taken Our Wood!"149 The pervasiveness of flags, posters, and other political ephemera at the event, while ironically appropriated from the Loyalist lexicon, nevertheless reflects the incredible saturation of images and words that have continually served to stake territorial claims and reinforce collective political identities throughout the Bogside and the city as a whole. Finally, the event itself, from its monumental yet fleeting commemoration of the Battle of the Bogside to the renewed presence of police surveillance atop Derry's city walls, reflects the deeply embedded and often volatile memory of conflict and contestation within Derry’s symbolic urban landscape.

Considered more broadly within the history of symbolic spatial practice in Derry, the bonfire provides a dramatic case study of the ways in which the spatial history of conflict continues to be both deeply embedded and symbolically present in the everyday urban spaces of

148 "'Teen gangs are holding communities to ransom," Derry Journal, August 16, 2016, 1.

${ }^{149}$ Eamon Sweeney, "Verbal fallout over Bogside bonfire continued yesterday," Derry Journal, August 16, 2016, 6 . 
the Bogside. Moments of violence, resistance, rupture, and tragedy remain visually present within the matrix of political murals and ephemeral objects situated throughout the urban landscape, with many of the same urban spaces upended by conflict during the early years of the Troubles continually reactivated in an ongoing battle of images and ephemera. To borrow Lefebvre's terminology, this multitude of symbolic spatial practices continually utilized in the Bogside represents not only a "complete mobilization" of space, but also of specific spatial histories, collective memories, and shared identities through the deployment of a dynamic lexicon of visual imagery, physical materials, and performative practices. ${ }^{150}$

Ultimately, understanding the complex spatial and symbolic history of conflict in Derry remains vital not only to the city itself moving forward, but also to more fully elucidating the considerable impacts of violent conflict, systemic inequality, and sustained precarity in contemporary cities. By tracing a spatial history of conflict and upheaval in the Bogside as it shapes a dynamic field of symbolic spatial objects and practices, this thesis has attempted to define an approach for understanding symbolic space in contested urban landscapes. Following the Brexit vote in June 2016, in which Northern Ireland voted 56\% in favor of remaining in the European Union, new political anxieties emerged surrounding the possible return of strict border controls between Northern Ireland and the Republic, prompting outcry within communities near the border. ${ }^{151}$ Recently, such dissent has even led Sinn Fein leader Michelle O'Neill to state that Brexit "has brought the issue of Irish reunification firmly back on to the political agenda."152 Given these recent political developments, the symbolic spaces and landscapes of Northern Irish

\footnotetext{
${ }^{150}$ Lefebvre, The Urban Revolution, 130.

151 "Life on the Edge: How Will Brexit Affect the Northern Irish Border?" The Guardian, April 15, 2017, https://www.theguardian.com/uk-news/2017/apr/15/brexit-northern-irish-border.

152 "Brexit Has Returned Irish Unity to Political Agenda - O’Neill." ITV News. Accessed April 16, 2017. http://www.itv.com/news/utv/2017-04-16/brexit-has-returned-irish-unity-to-political-agenda-oneill/.
} 
cities are likely to remain vital and evolving avenues for similar investigation for the foreseeable future.

More broadly, this examination of the relationship between spaces of conflict and symbolic spatial practices in Derry offers a potential mode of analysis for other contested cities, particularly those with spatial histories of violent conflict, colonial occupation, and systemic segregation. Clear parallels can be traced to the Israeli-Palestinian conflict, while a thorough analysis of how "defensible space" planning strategies, police violence, and systemic racial inequality intersect in the spatial histories and symbolic landscapes of American cities such as St. Louis or Chicago. In all of these cases, however, an emphasis on site-specific histories, collective memory and communal identity is key to revealing the mechanisms through which the built environment can both shape and reflect - in virtually all available surfaces and objects - urban conflict and contestation. As the Bogside illustrates, spatial history and collective memory in areas of conflict can be continually made manifest through a diverse array of symbolic visual media and performative spatial practices, with the past remaining both deeply embedded and symbolically present in the everyday experience of contested urban spaces. 


\section{Bibliography}

Bishop, Ryan, Gregory K. Clancey, and John Phillips, eds. The City as Target. Postcolonial Politics; 4. Abingdon, Oxon; New York, NY: Routledge, 2012.

Boyd, Gary A \& Denis Linehan, eds. Ordnance: War + Architecture \& Space. London: Routledge, 2013.

“Brexit Has Returned Irish Unity to Political Agenda - O’Neill.” ITV News. Accessed April 16, 2017. http://www.itv.com/news/utv/2017-04-16/brexit-has-returned-irish-unity-topolitical-agenda-oneill/.

Brighenti, Andrea Mubi. "At the Wall: Graffiti Writers, Urban Territoriality, and the Public Domain.” Space and Culture 13, no. 3 (April 15, 2010): 315-32.

Crane, Sheila. "Rewriting the Battles of Algiers: Ephemeral Tactics in the City at War." Space and Culture 18, no. 4 (November 2015): 1-51.

Crowley, Tony. "Hegemonic Shifts: The Latest from the Walls of Northern Ireland." Estudios Irlandeses, no. 10 (January 2015): 58-76.

Dawson, Graham. "Trauma, Place and the Politics of Memory: Bloody Sunday, Derry, 19722004.” History Workshop Journal, no. 59 (2005): 151-78.

Deane, Seamus. “Why Bogside?” Honest Ulsterman no. 27 (1971): 1-8.

Derry Now. "New mural showing solidarity with Rojava unveiled at Free Derry Corner." Last modified January 30, 2017. https://www.derrynow.com/news/new-mural-showingsolidarity-rojava-unveiled-free-derry-corner/142611.

Feldman, Allen. Formations of Violence: The Narrative of the Body and Political Terror in Northern Ireland. Chicago : University of Chicago Press, 1991.

Goalwin, Gregory. "The Art of War: Instability, Insecurity, and Ideological Imagery in Northern Ireland's Political Murals, 1979-1998." International Journal of Politics, Culture, and Society 26, no. 3 (May 31, 2013): 189-215.

Graham, Stephen, ed. Cities, War, and Terrorism: Towards an Urban Geopolitics. Miaden, MA: Blackwell Publishing, 2004.

Herscher, Andrew. "The Language of Damage." Grey Room 7 (2002): 68-71.

—. "Urban Formations of Difference: Borders and Cities in Post-1989 Europe." European Review 13, no. 2 (2005): 251-60.

_. "Counter-Heritage and Violence." Future Anterior 3, no. 2 (2006): 24-33. 
__. "Warchitectural Theory." Journal of Architectural Education 61, no.3 (2008): 34-43.

Jarman, Neil. Material Conflicts: Parades and Visual Displays in Northern Ireland.

Explorations in Anthropology. Oxford [England] ; Berg, 1997.

_. "Painting Landscapes: The Place of Murals in the Symbolic Construction of Urban Space." In Symbols in Northern Ireland, edited by Anthony Buckley. Belfast: Institute of Irish Studies, 1998. Accessed February 27, 2017. http://cain.ulst.ac.uk/bibdbs/murals/jarman.htm\#chap5

Kenzari, Bechir, ed. Architecture and Violence. Barcelona; New York: Actar, 2011.

Lefebvre, Henri. The Production of Space. Oxford, OX, UK ; Blackwell, 1991.

—. The Urban Revolution. Minneapolis: University of Minnesota Press, 2003.

"Life on the Edge: How Will Brexit Affect the Northern Irish Border?" The Guardian, April 15, 2017, https://www.theguardian.com/uk-news/2017/apr/15/brexit-northern-irish-border.

Murals of Derry. Derry, Northern Ireland: Guildhall Press, 2016.

McDowell, Sara and Catherine Switzer. "Violence and the Vernacular: Conflict, Commemoration, and Rebuilding in the Urban Context." Buildings \& Landscapes: Journal of the Vernacular Architecture Forum 18, no. 2 (2011): 82-104.

Ó Dochartaigh, Niall. From Civil Rights to Armalites: Derry and the Birth of Irish Troubles. Houndmills, Basingstoke, Hampshire; Palgrave/Macmillan, 2005.

Principal Conclusions and Overall Assessment of the Bloody Sunday Inquiry. 2010. https://www.gov.uk/government/uploads/system/uploads/attachment data/file/279167/00 30.pdf

Pringle, Peter, and Philip Jacobson. Those Are Real Bullets, Aren't They?: Bloody Sunday, Derry, 30 January 1972. London : Fourth Estate, 2000.

Report of the Bloody Sunday Inquiry. 2010. https://www.gov.uk/government/publications/report-of-the-bloody-sundayinquiry.

Report of the Tribunal appointed to inquire into the events on Sunday, 30th January 1972. 1972. http://cain.ulst.ac.uk/hmso/widgery.htm

Rolston, Bill. "'The Brothers on the Walls': International Solidarity and Irish Political Murals." Journal of Black Studies 39, no. 3 (April 13, 2007): 446-70. 
- "Changing the Political Landscape: Murals and Transition in Northern Ireland." Irish Studies Review 11, no. 1 (April 2003): 3-16.

- Politics and Painting: Murals and Conflict in Northern Ireland. Rutherford, N.J.:

Fairleigh Dickinson University Press, 1991.

_. "Re-Imaging: Mural Painting and the State in Northern Ireland." International Journal of Cultural Studies 15, no. 5 (September 1, 2012): 447-66.

—. "The War of the Walls: Political Murals in Northern Ireland." Museum International 56, no. 3 (September 1, 2004): 38-45.

Shea, Margo. "“Once again it Happens": Collective Remembrance and Irish Identity in Catholic Derry, Northern Ireland 1896-2008." Ph.D. Diss., University of Massachusetts Amherst, 2010.

Sluka, Jeffrey A. "The Writing's on the Wall: Peace Process Images, Symbols and Murals in Northern Ireland." Critique of Anthropology. 16 (1996): 381-394.

Stetler, Russell. The Battle of Bogside: The Politics of Violence in Northern Ireland. London: Sheed \& Ward, 1970.

Sweeney, Eamon. "2,000 crowd see Bogside bonfire set alight.” Derry Journal, August 19, 2016.

—. "Verbal fallout over Bogside bonfire continued yesterday." Derry Journal, August 16, 2016.

“'Teen gangs are holding communities to ransom."” Derry Journal, August 16, 2016.

Weizman, Eyal. Hollow Land: Israel's Architecture of Occupation. London: Verso, 2007.

- Forensic Architecture: Notes from Fields and Forums. Ostfildern: Hatje Cantz, 2012.

—. "Lethal Theory." Log, no. 7 (2006): 53-77.

\section{Archival Material}

Crowley, Tony and Claremont Colleges Digital Library. "Murals of Northern Ireland Collection." http://ccdl.libraries.claremont.edu/cdm/landingpage/collection/mni

Ulster University. “Conflict Archive on the Internet (CAIN).” http://cain.ulst.ac.uk/index.html 


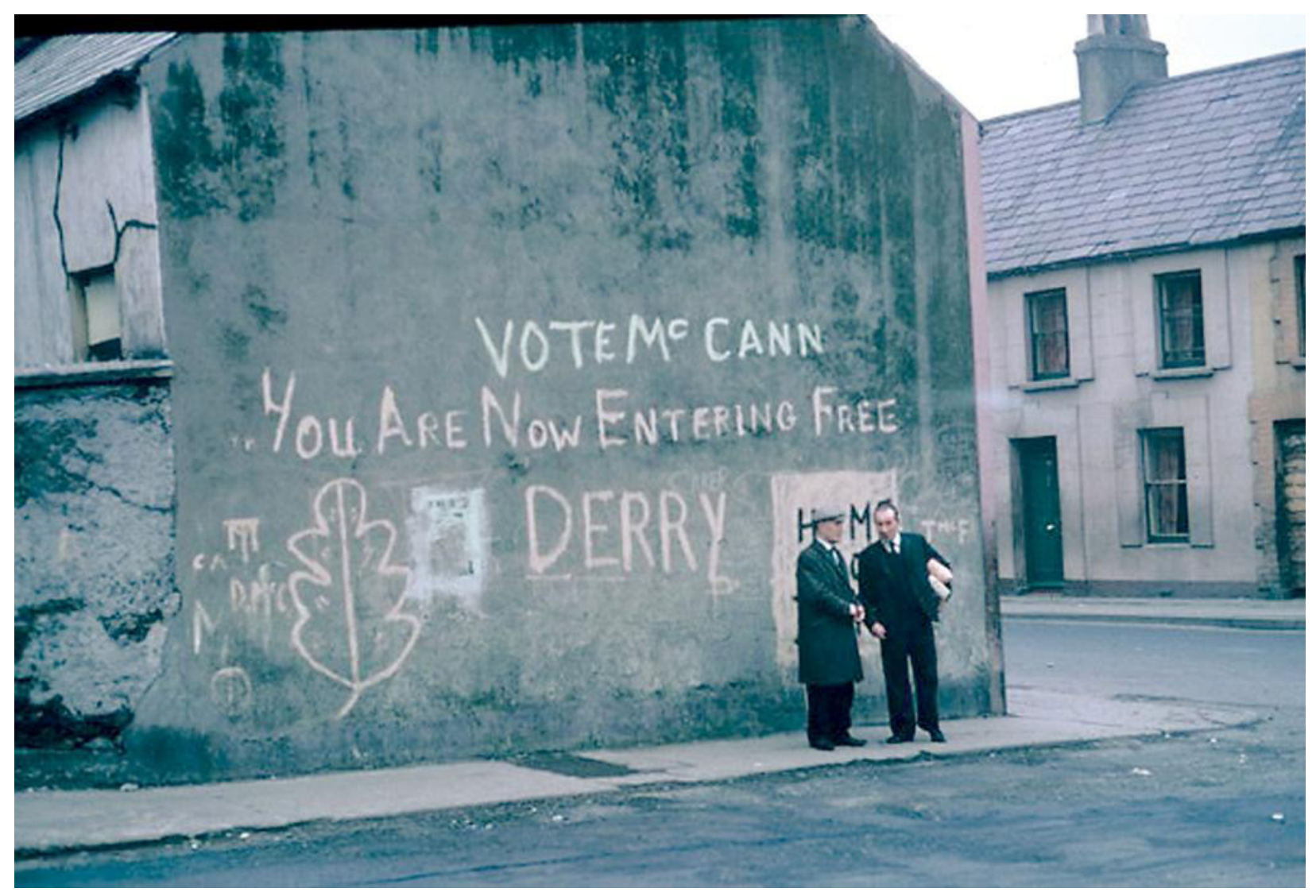

Figure 1.1. Original hand-painted "Free Derry" slogan, January 1969 (Source: Museum of Free Derry, http://www.museumoffreederry.org/content/free-derry.) 


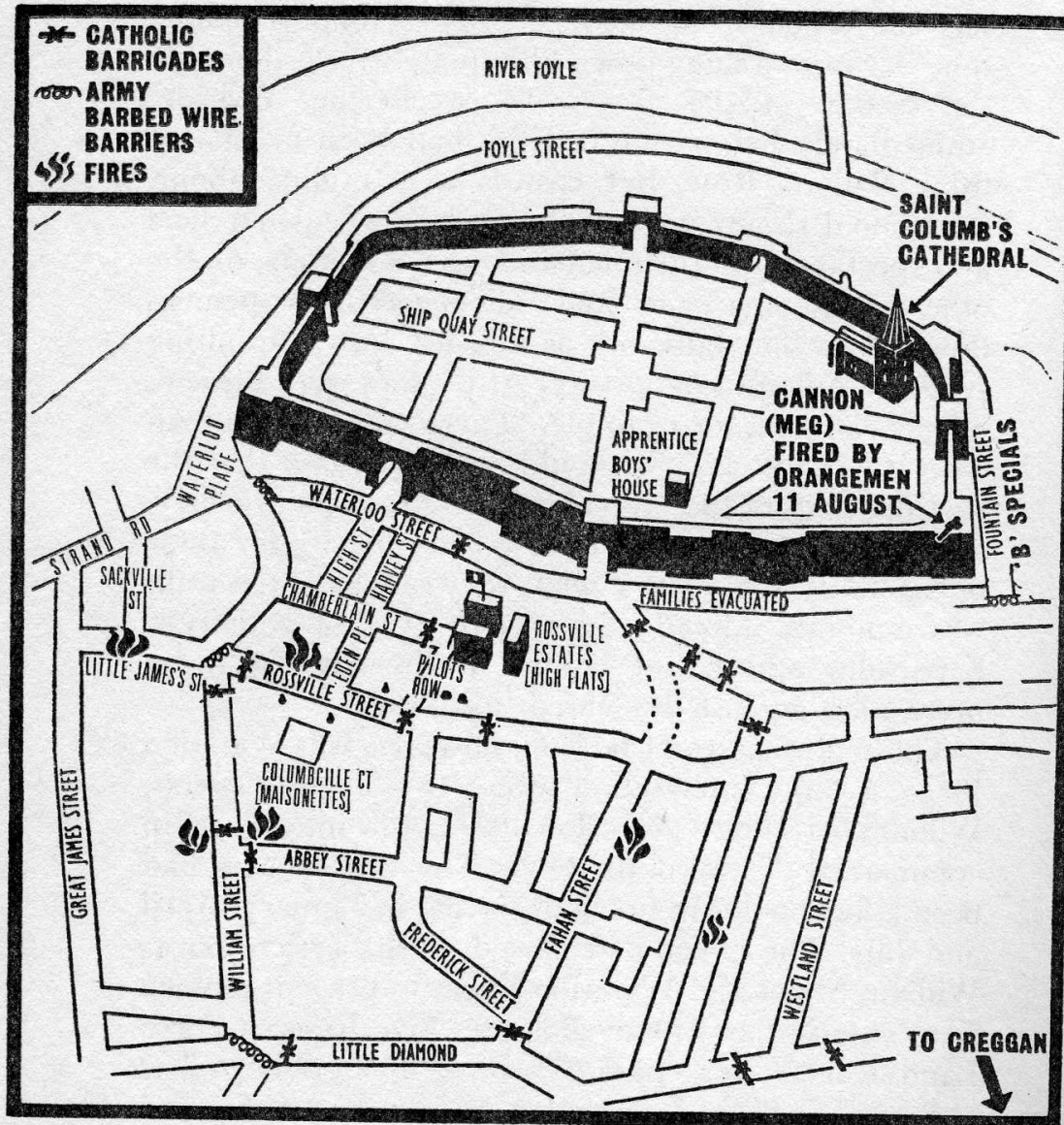

Figure 1.2. Diagrammatic map of Derry, showing basic street layout, army barricades, and Catholic barricades during the Battle of the Bogside (Source: Stetler, The Battle of Bogside, 72.) 


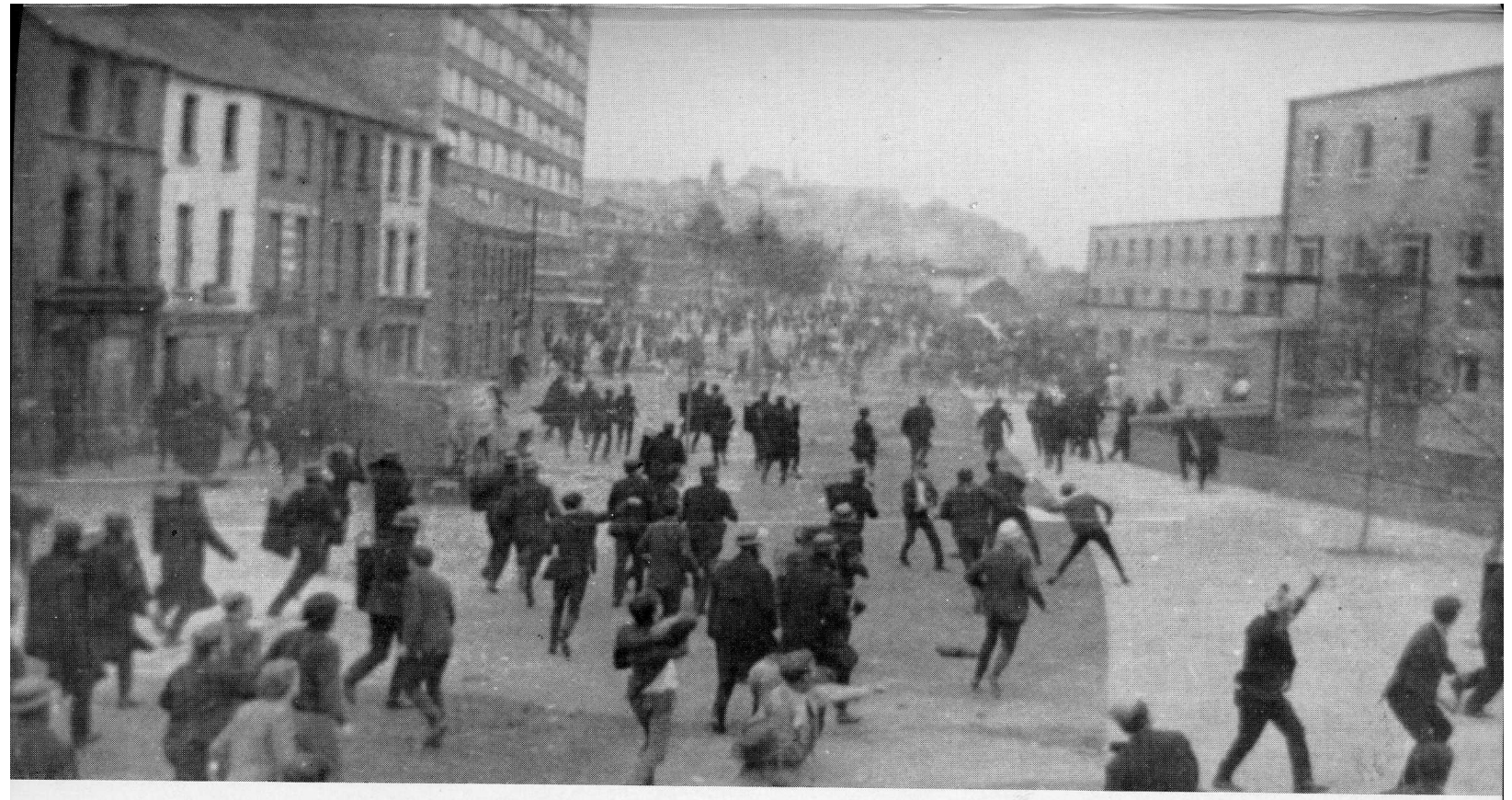

Rossville St, August 12. The Ruc penetrate Rossville St, followed by civilian supporters throwing stones at the maisonettes on the righthand side of the street. The nine-storey flats known as Rossville Estates are visible on the left.

Figure 1.3. Photograph showing the RUC charge into Rossville Street, supported by Protestant civilians, during the Battle of the Bogside (Source: Stetler, The Battle of Bogside)

bottom The Rossville St barricade

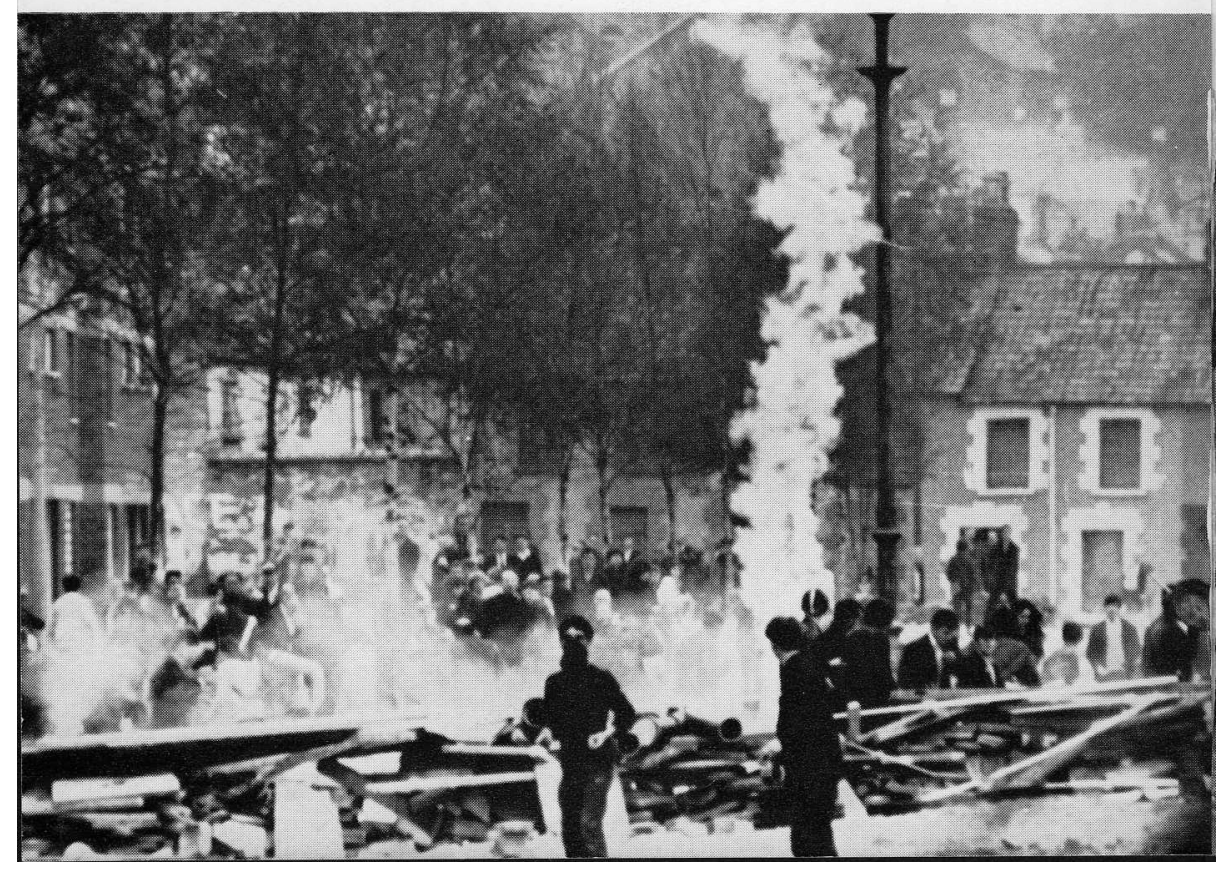

Figure 1.4. Photograph showing the Rossville Street barricade during the Battle of the Bogside (Source: Stetler, The Battle of Bogside) 


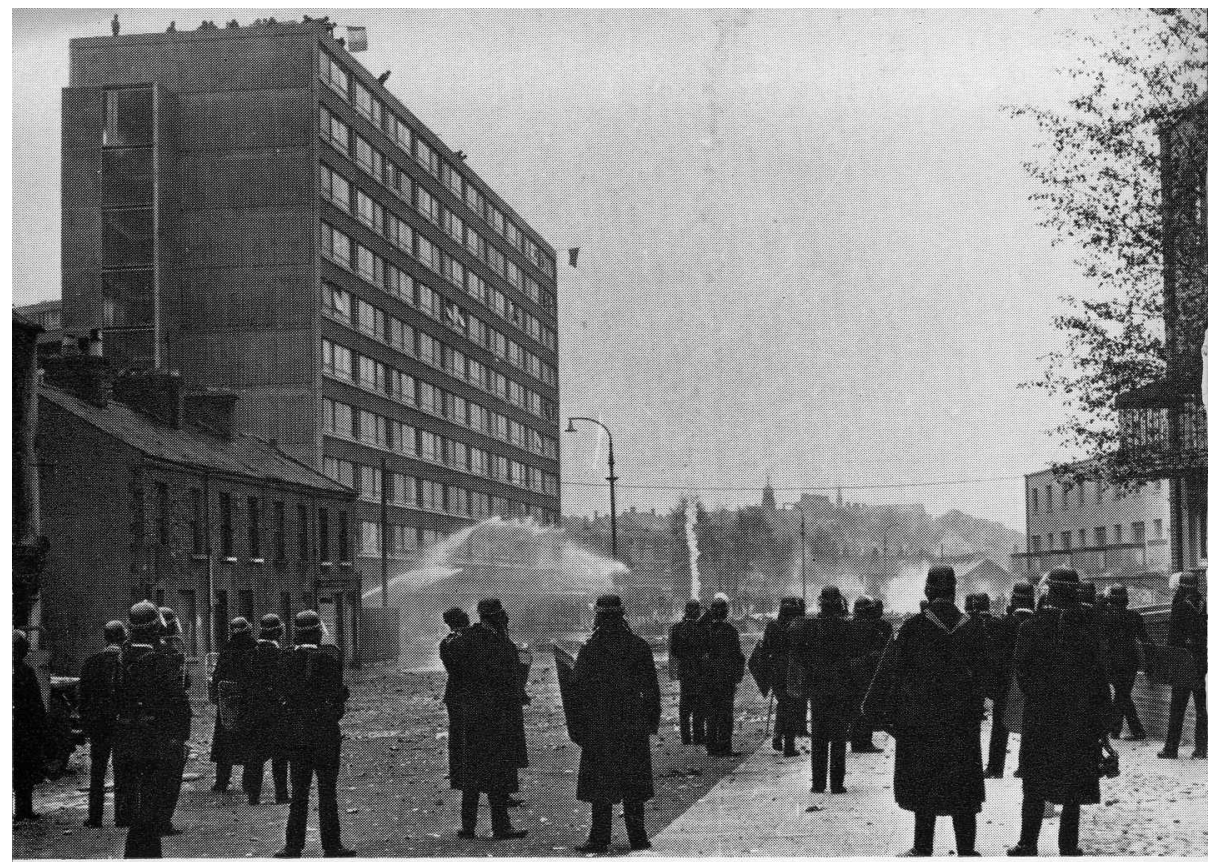

top Rossville St, August 13. The Ruc Reserve Force firing cs towards the Rossville St barricade from the vicinity of the maisonettes.

Figure 1.5. Photograph showing the RUC firing CS gas towards the Rossville Street barricade during the Battle of the Bogside (Source: Stetler, The Battle of Bogside)

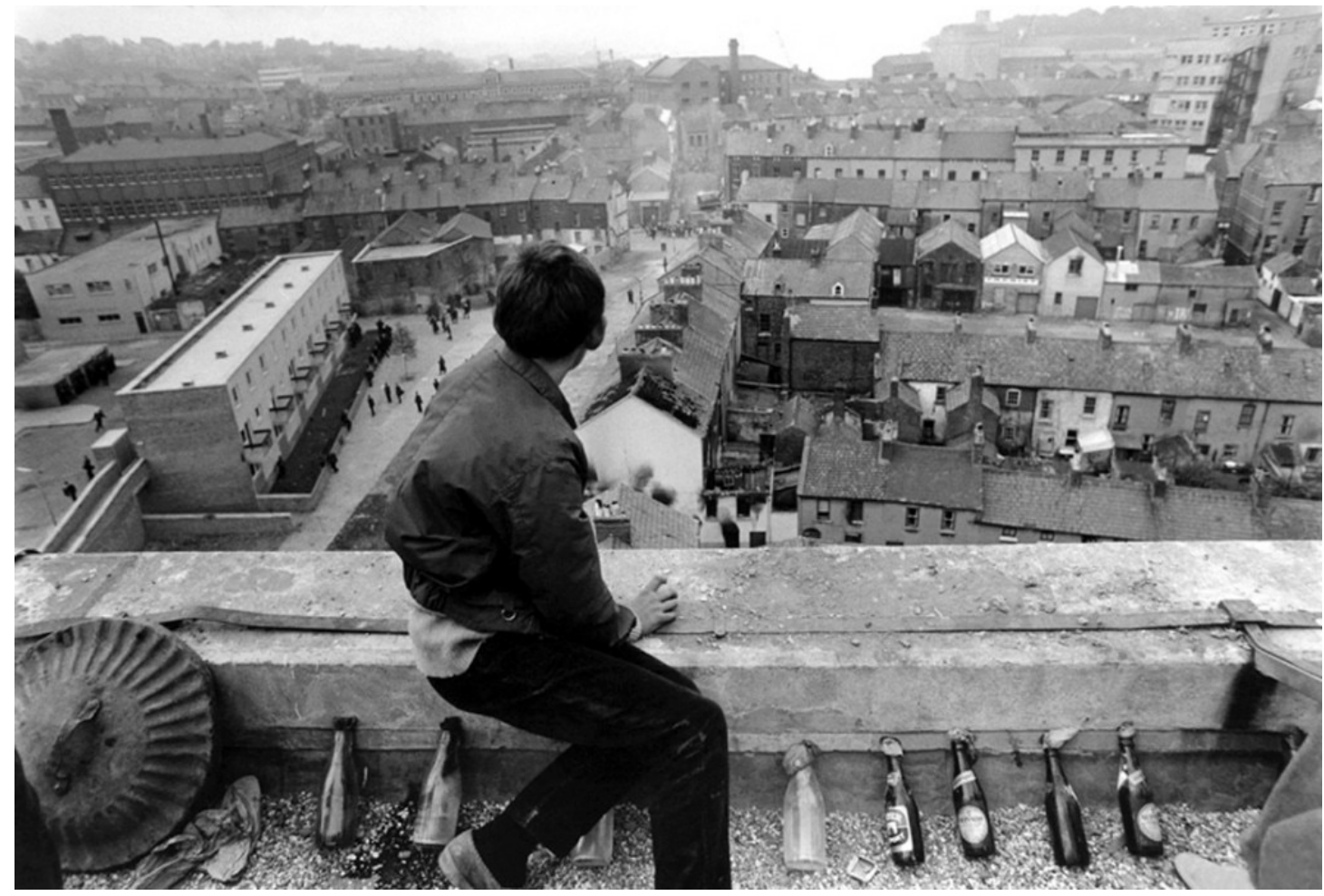

Figure 1.6. Photograph showing a Bogside youth stationed atop the Rossville Flats, with several petrol bombs nearby (Source: Fondation Gilles Caron, Contact Press Images, http://contact.photoshelter.com/ gallery-image/Gilles-Caron-Northern-Ireland-August-1969/G0000eaXGnX5RBQo/I0000PIFqZiU4gGU) 


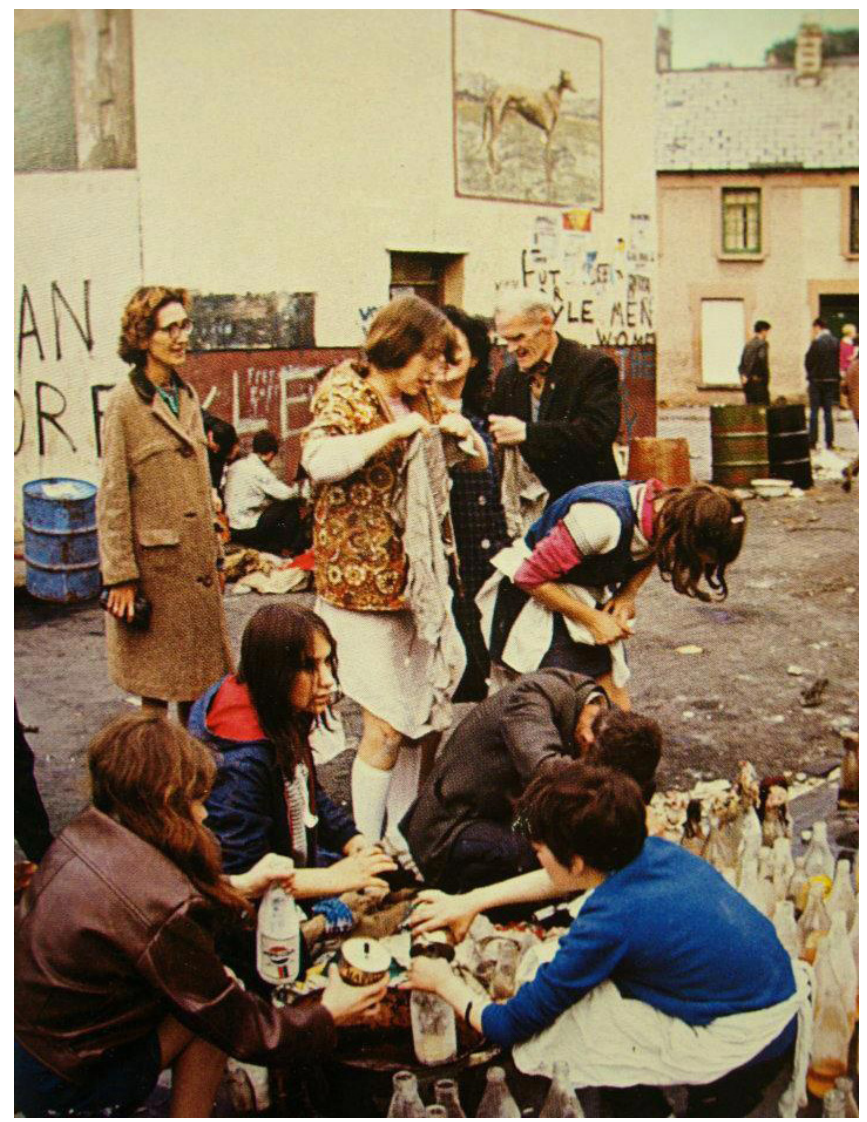

Figure 1.7. Photograph showing women and children producing petrol bombs during the Battle of the Bogside (Source: Museum of Free Derry, http://www.museumoffreederry.org/content/12-14-august )

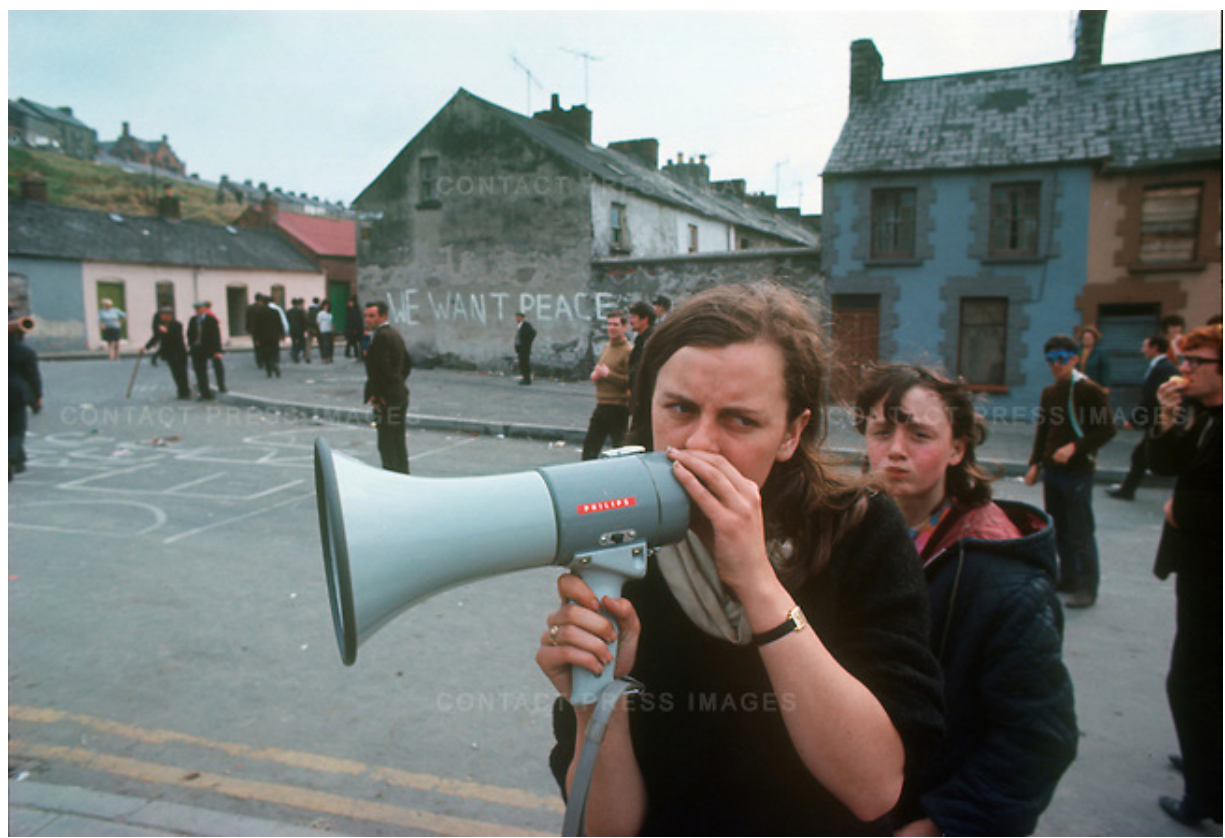

Figure 1.8. Photograph showing Bernadette Devlin, Republican activist, coordinating efforts during the Battle of the Bogside (Source: Gilles Caron, Contact Press Images, http://contact.photoshelter.com/ gallery-image/Gilles-Caron-Northern-Ireland-August-1969/G0000eaXGnX5RBQo/I0000ET07fRRZrjo) 


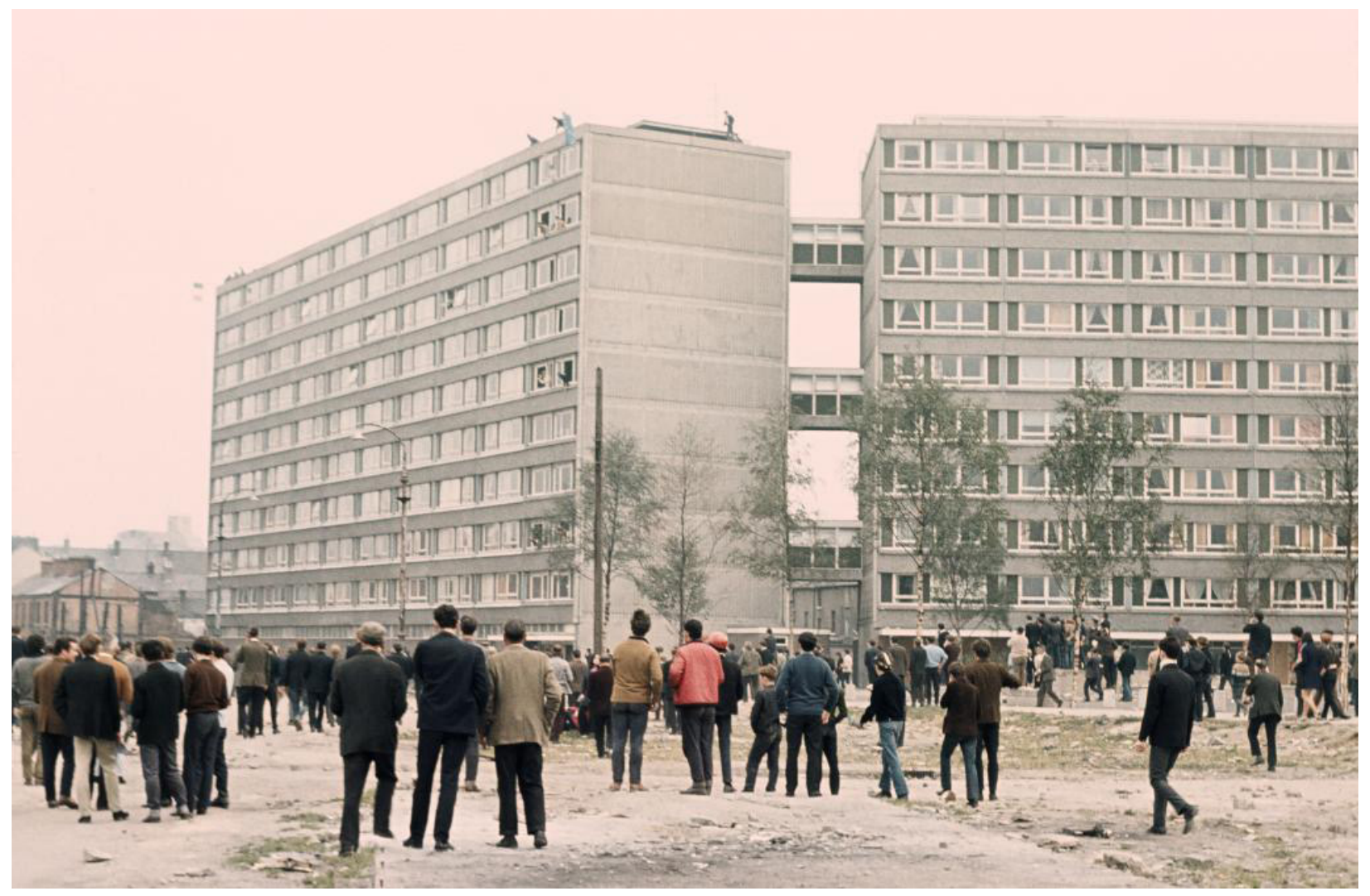

Figure 1.9. Photograph showing the Rossville Flats during the Battle of the Bogside, with Irish tricolor and Starry Plough flags visible at rooftop corners of the building on the left (Source: Museum of Free Derry, http://www.museumoffreederry.org/content/battle-bogside) 


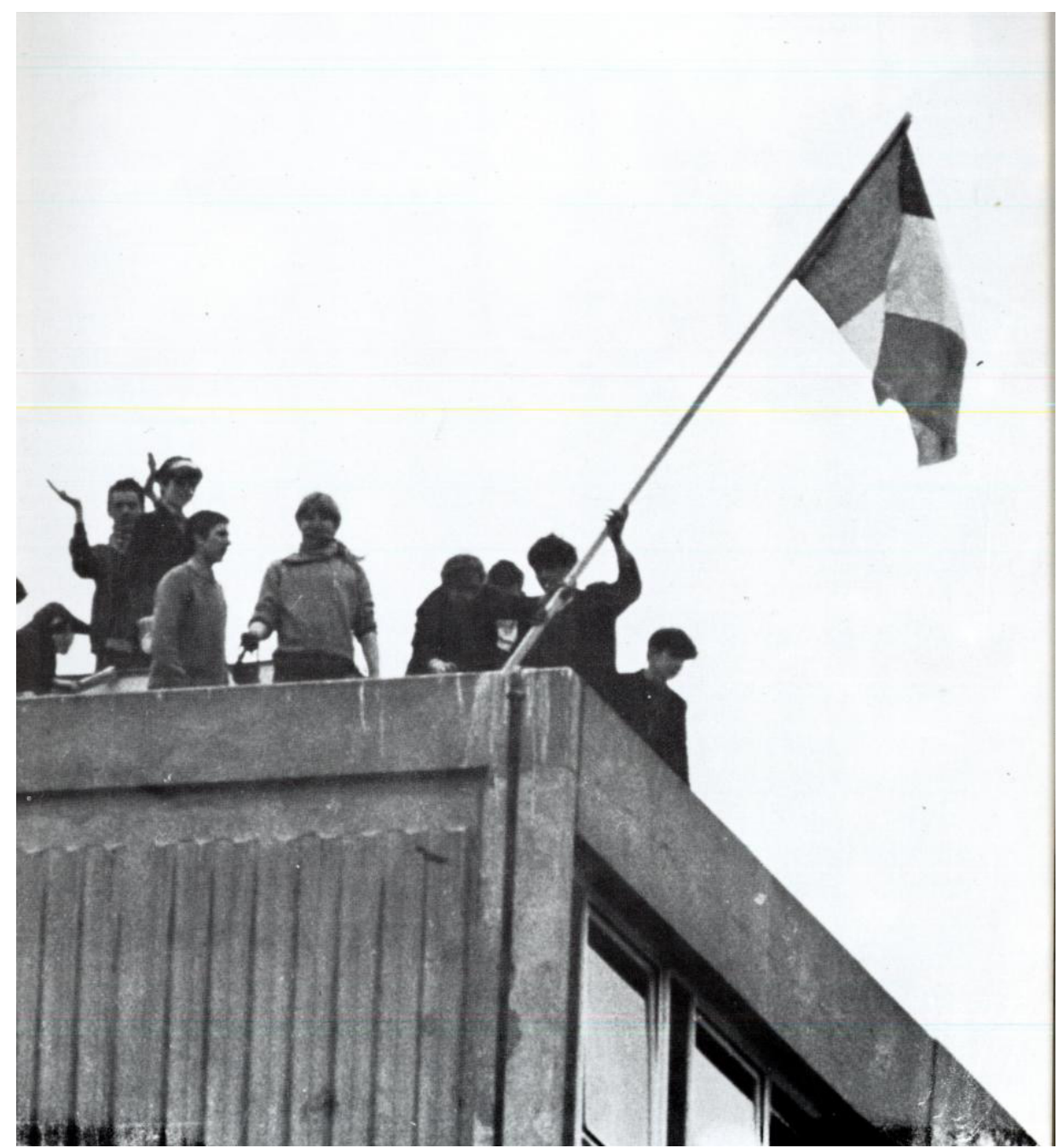

Figure 1.10. Photograph showing the Irish tricolor flag being flown by Bogside youths stationed on the roof of the Rossville Flats (Source: Museum of Free Derry, http://www.museumoffreederry.org/ content/12-14-august.) 


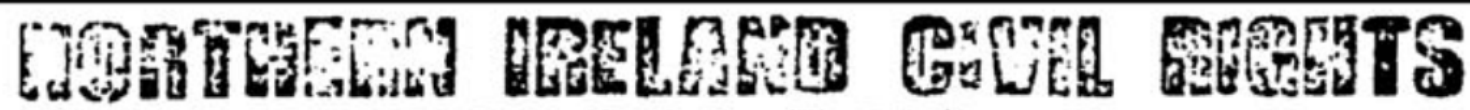

ners

GIGAHTIC

OP

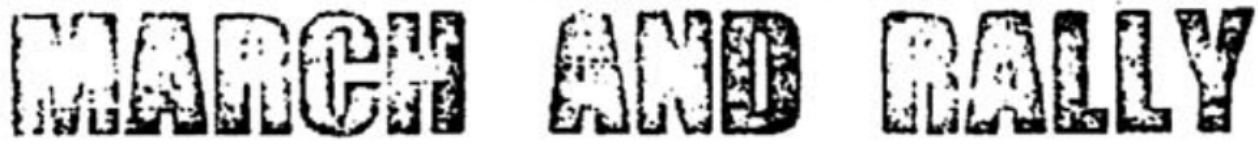

DERRY CITY - SUNDAY, 30\$h JANUARY, 1972

$\star$

Assemble at 2 p.m. in the 8ISIHOPS FIELDS and March to the GUILCHALL SQUARE for Public Meeting

$\star$

Spcakcrs:

Lord Fenner Brockyay

Rev. Terence McCoughey (Presbyterian Minister)

Edwina Stewart, Hon. Secretary. N.I.C.R.A.

Morgo Collins. Executive Committce, N.I.C.R.A.

John Hume, M.P.

Ivan Cooper, M.P.

Bernodcite Devlin, M.P.

Choirman:

Rory MCShane, N.I.C.R.A. Executive Committee

$\star$

BEAT BRIAN'S BAN BY ORGANISING BUSES FROM YOUR AREA TO DERRY THIS SUNDAY

$\star$

OBSERYERS WILL BE PRESENT TROM THE NATIONAL COUNCIL OF CIVIL LIBERTIES. LONDON, AND THE MOVEMENT FOR COLONIAL FREEDOM (LIBERATION), LONDON

Figure 1.11. Poster for Northern Ireland Civil Rights Association march on January 30, 1972, including description of planned route from Creggan to Guildhall (Source: Report of the Bloody Sunday Inquiry, Volume II, 474.) 




Figure 1.12. Map showing several strategic barriers planned by British Army leading up to Bloody Sunday, including those at Little James (12), Sackville (13), and William Streets (14) (Source: Principal Conclusions and Overall Assessment of the Bloody Sunday Inquiry, 15.) 


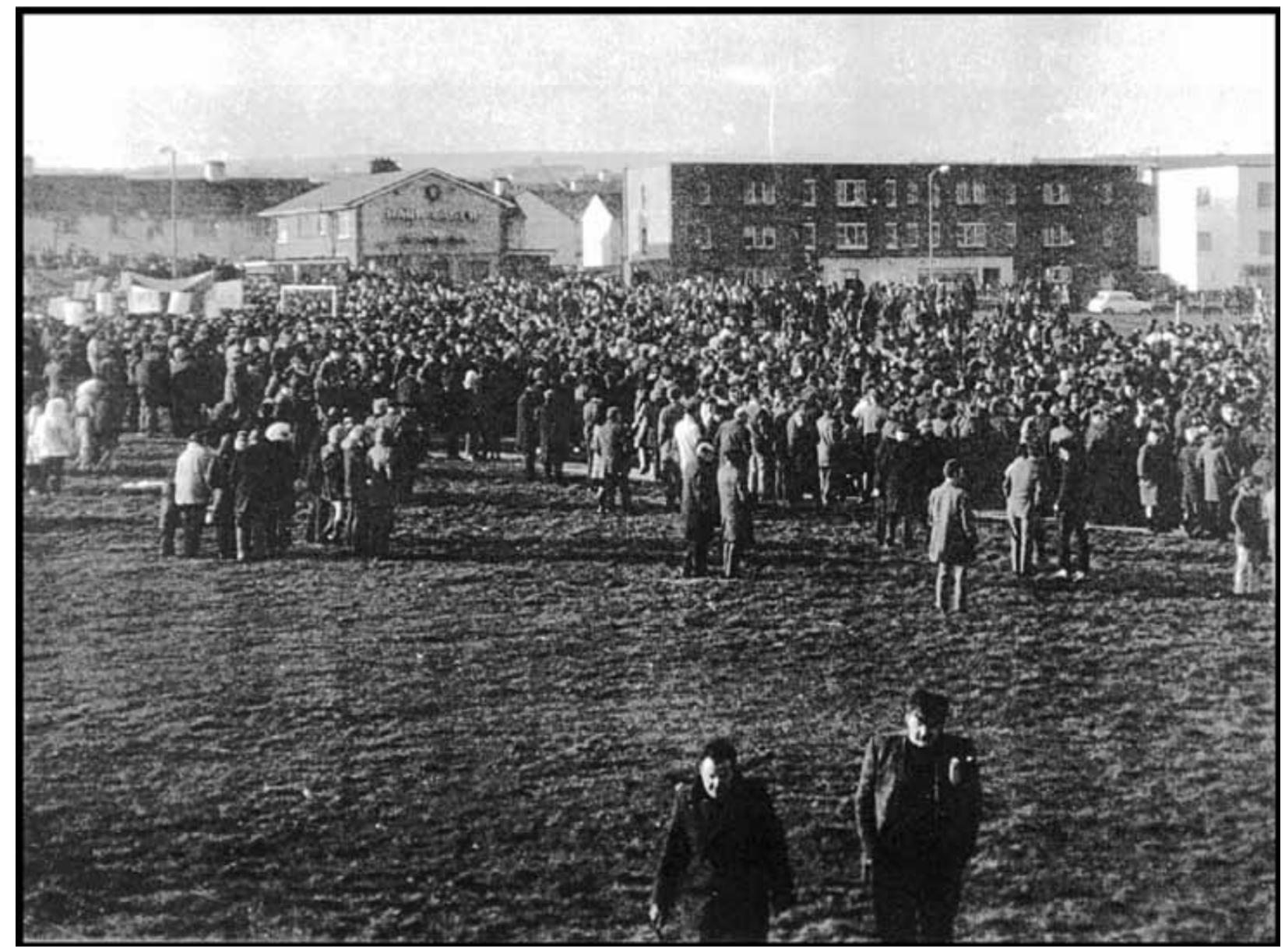

Figure 1.13. Photograph showing marchers gathering in the Creggan area on Bloody Sunday (Source: Report of the Bloody Sunday Inquiry, Volume II, 74.) 


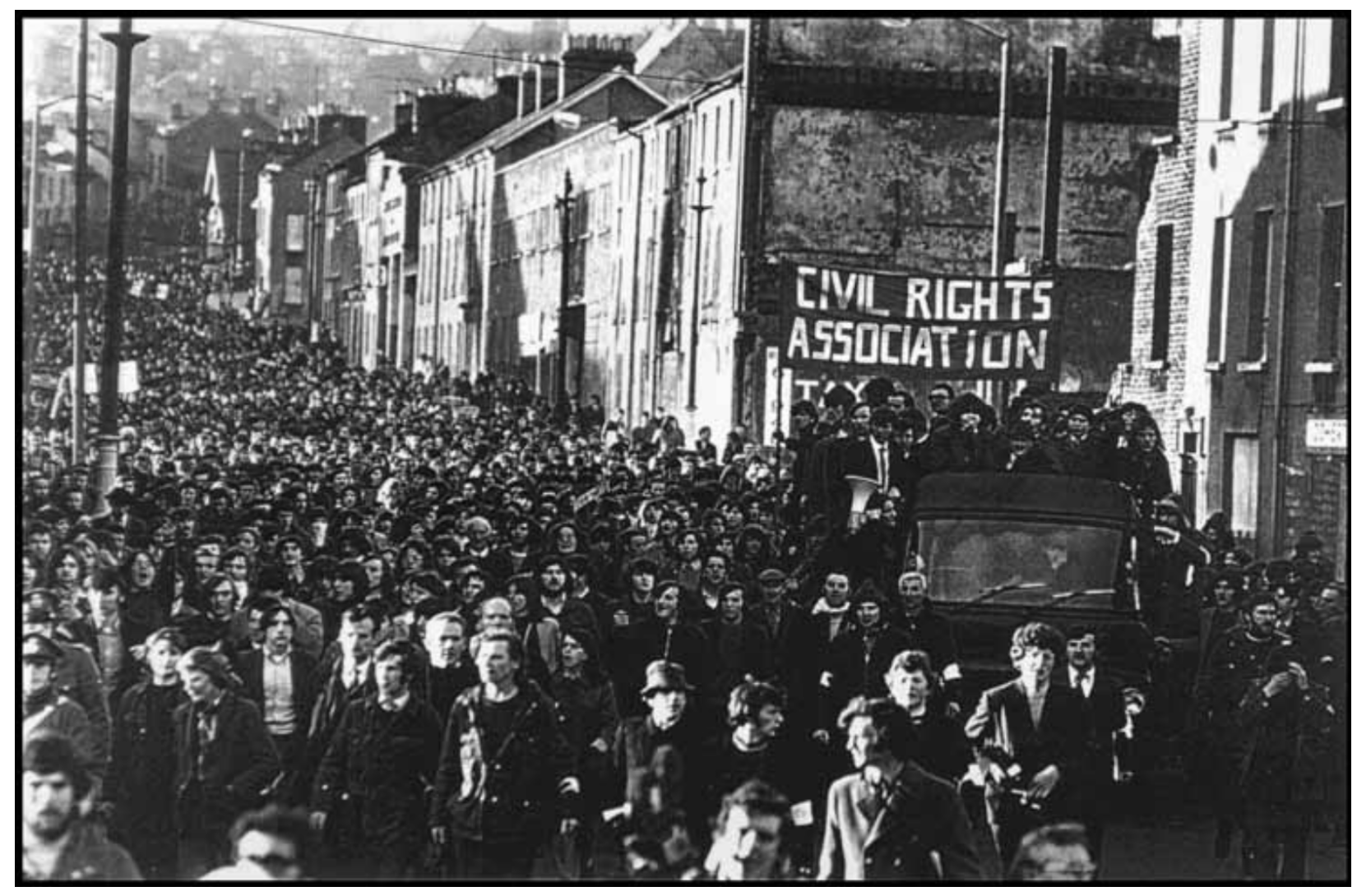

Figure 1.14. Photograph showing Bloody Sunday marchers moving into William Street (Source: Report of the Bloody Sunday Inquiry, Vol. 2, 80.) 


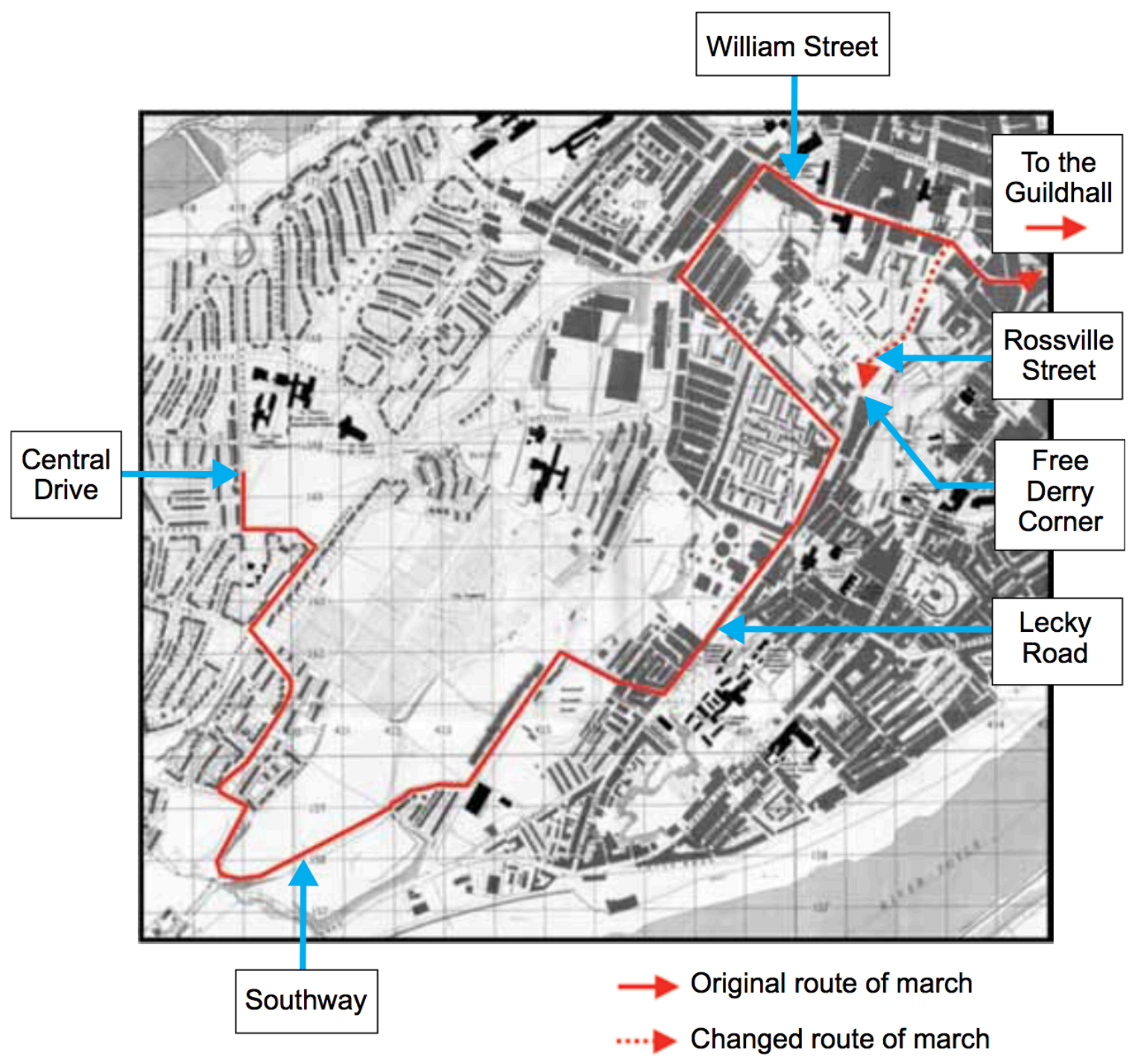

Figure 1.15. Map showing the original and revised routes for the civil rights march on Bloody Sunday (Source: Principal Conclusions and Overall Assessment of the Bloody Sunday Inquiry, 13.) 

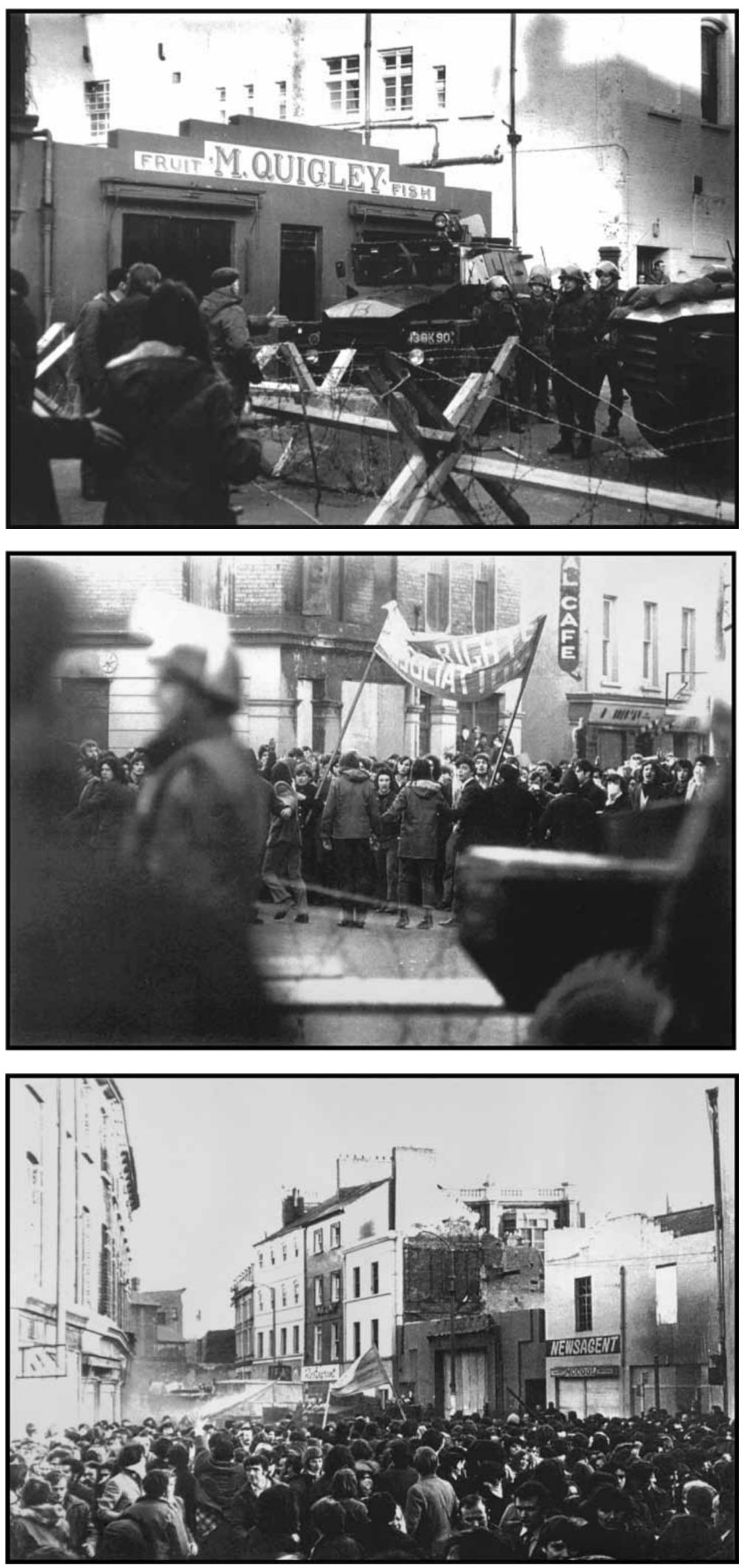

Figure 1.16. Photographs showing marchers and eventual riots near Barrier 14 in William Street (Source: Report of the Bloody Sunday Inquiry, Volume II, 94, 99.) 


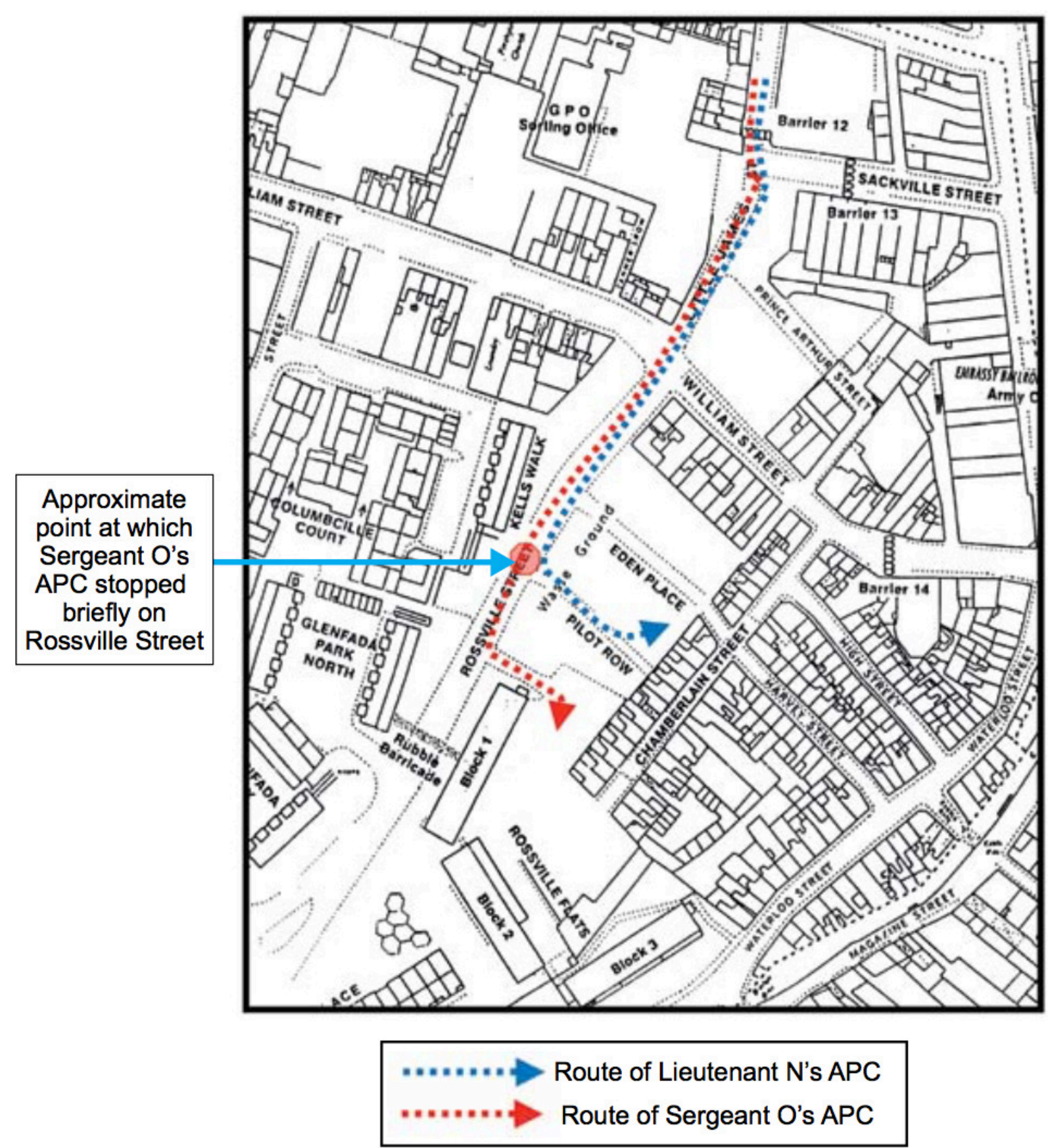

Figure 1.17. Map showing the paths of two armored vehicles entering the Bogside on Bloody Sunday (Source: Principal Conclusions and Overall Assessment of the Bloody Sunday Inquiry, 19.) 

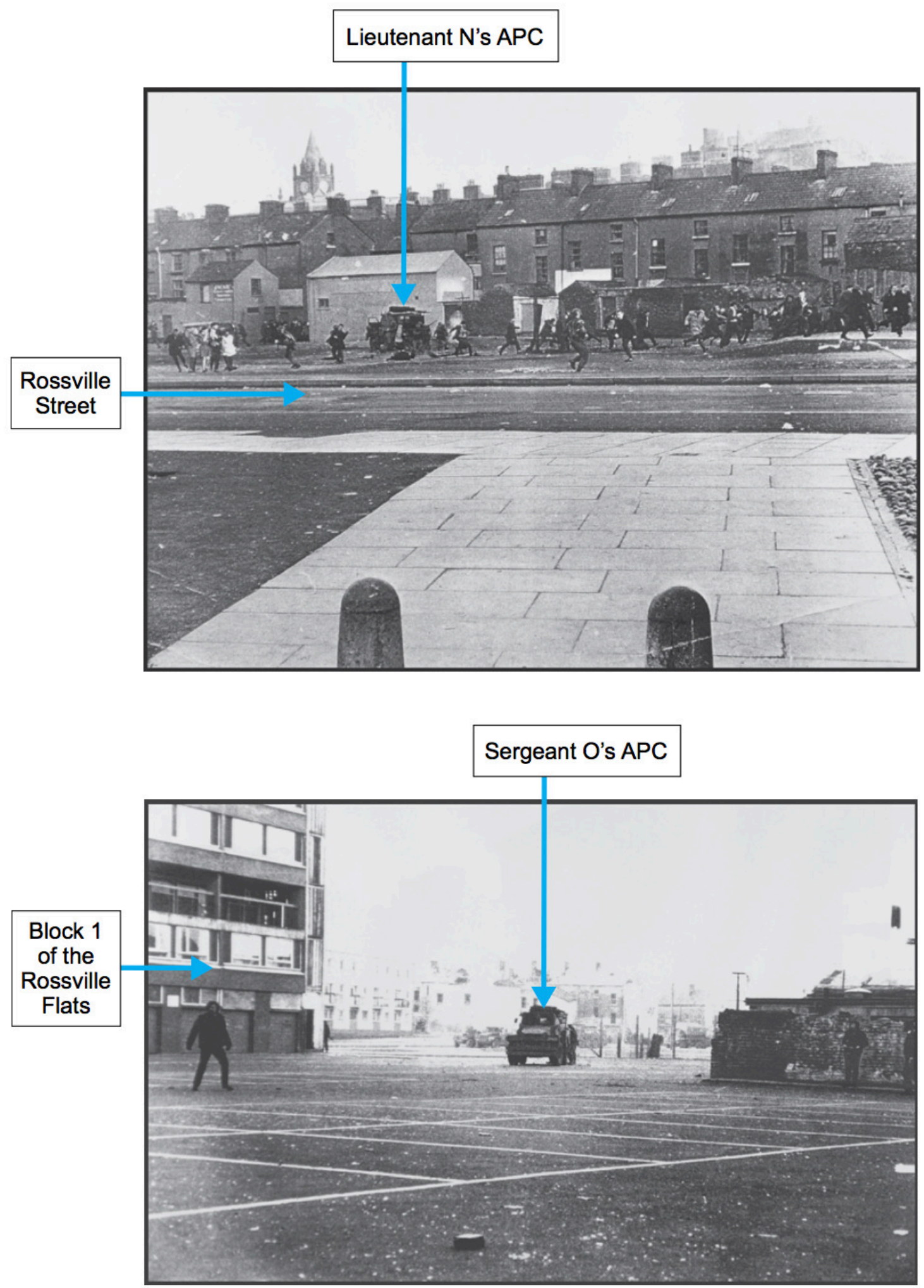

Figure 1.18. Photographs showing two armored vehicles entering the Eden Place waste ground and the Rossville Flats car park during Bloody Sunday (Source: Principal Conclusions and Overall Assessment of the Bloody Sunday Inquiry, 20.) 


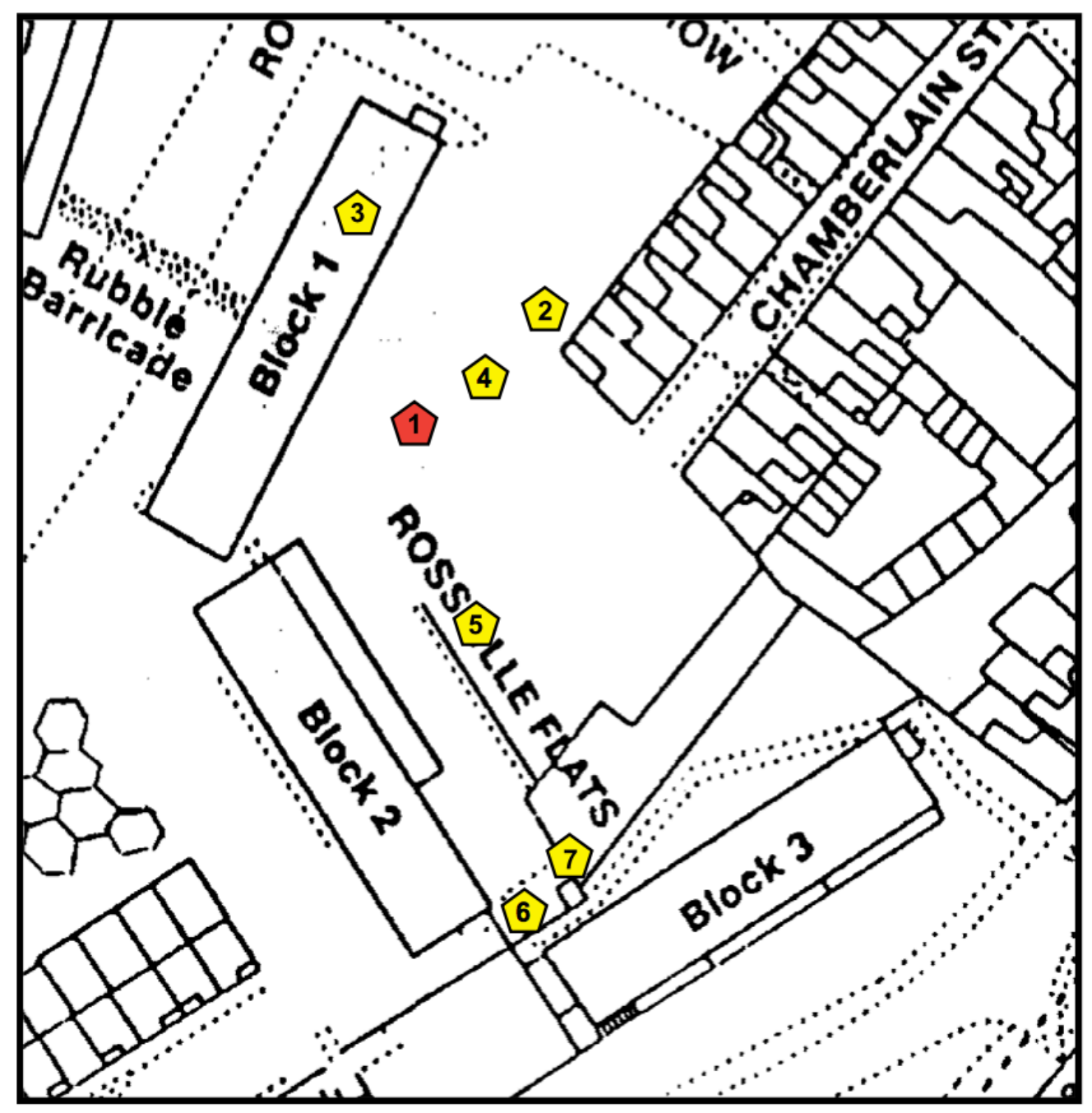

\begin{tabular}{|llll|}
\hline & $\begin{array}{l}\text { Casualty who was killed or mortally wounded in the car } \\
\text { park of the Rossville Flats } \\
1\end{array}$ & Jackie Duddy \\
& Casualties who were wounded in this area \\
2 & Margaret Deery & 5 & Michael Bradley \\
3 & Patrick Brolly & 6 & Pius McCarron \\
4 & Michael Bridge & 7 & Patrick McDaid \\
& & & \\
\end{tabular}

Figure 1.19. Map showing the first Bloody Sunday casualties in the vicinity of the Rossville Flats car park (Source: Principal Conclusions and Overall Assessment of the Bloody Sunday Inquiry, 23.) 


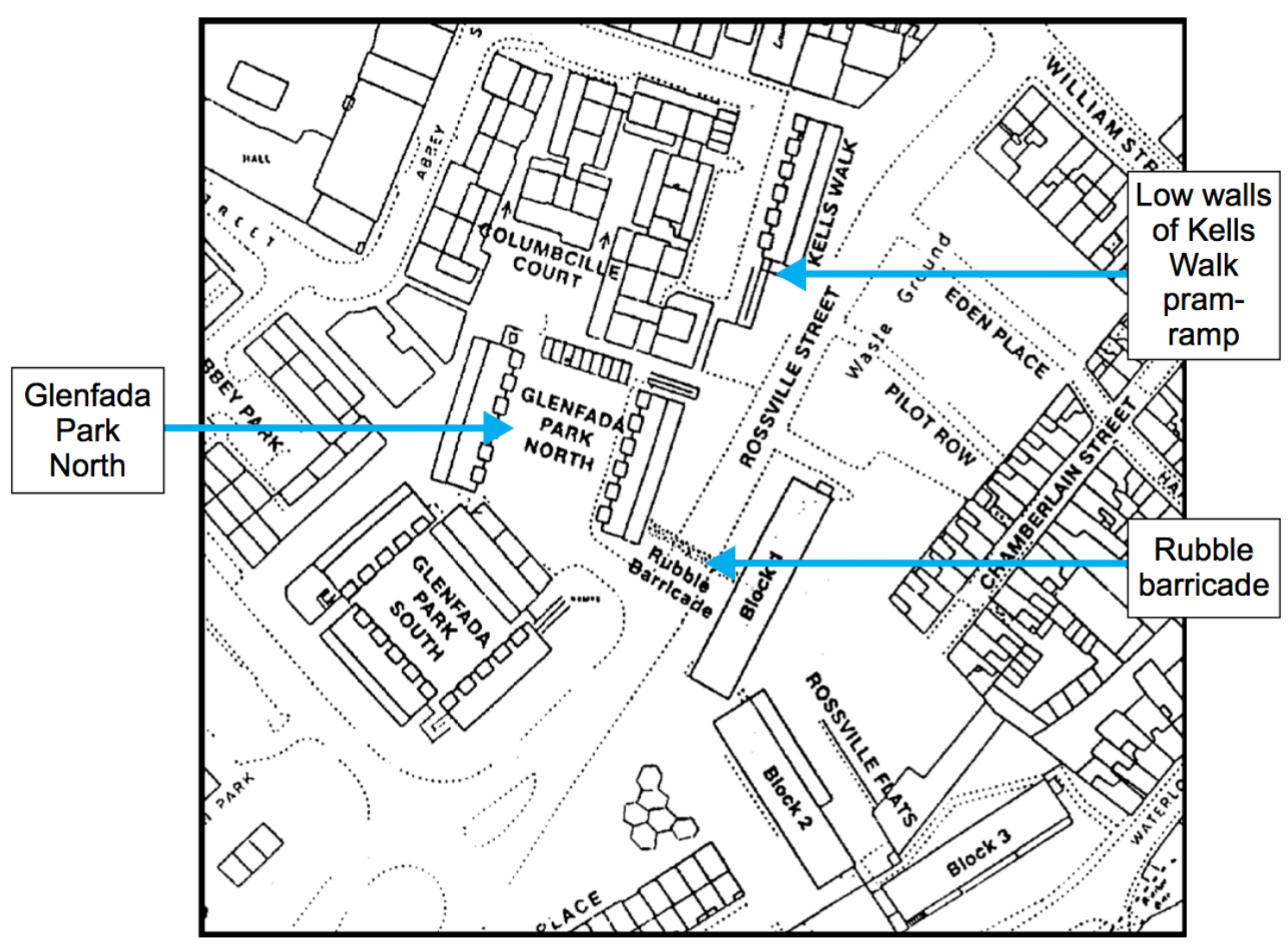

Figure 1.20. Map showing the rubble barricade erected across Rossville Street (Source: Principal Conclusions and Overall Assessment of the Bloody Sunday Inquiry, 24.) 


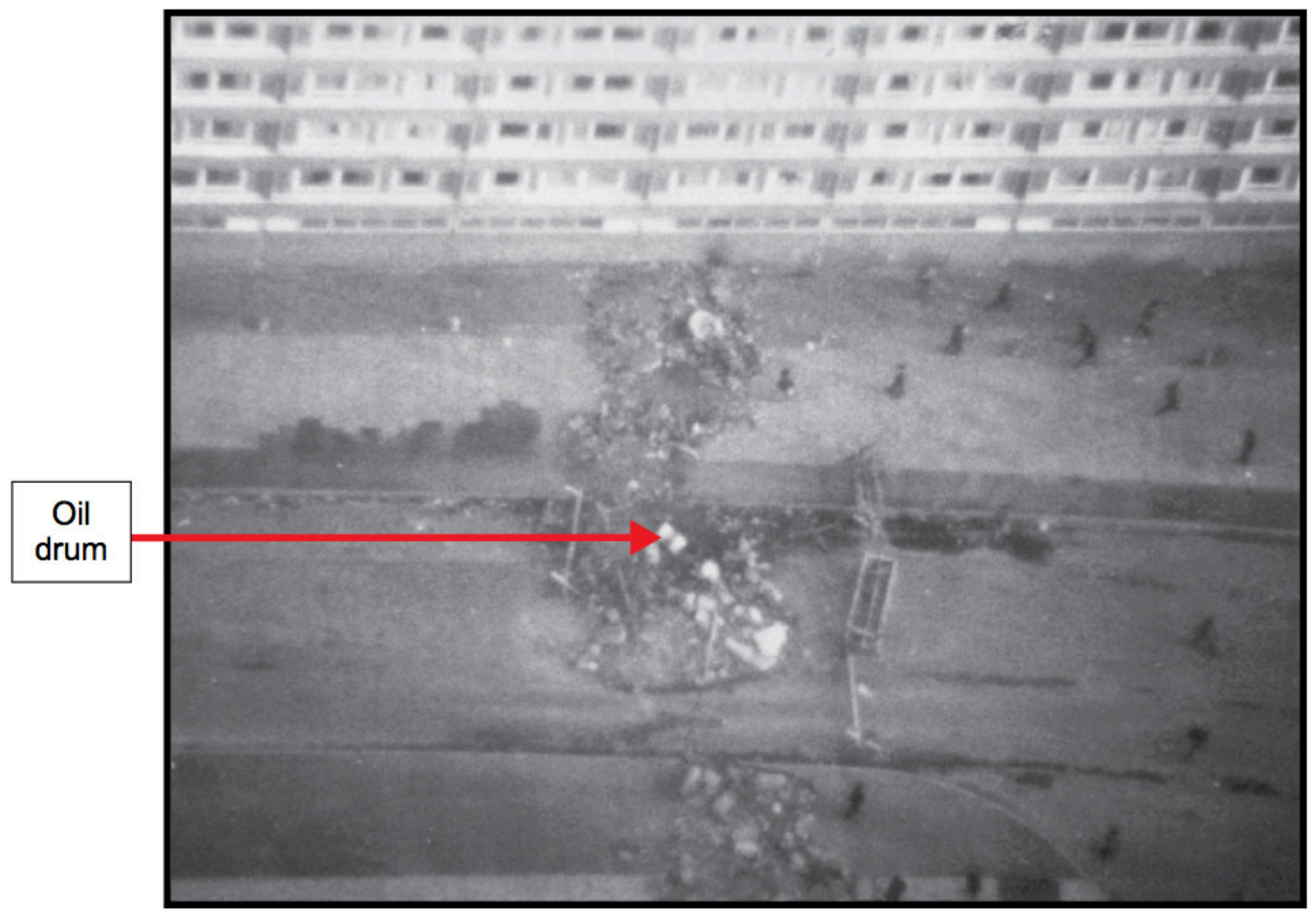

Figure 1.21. Aerial photograph of the rubble barricade across Rossville Street (Source: Report of the Bloody Sunday Inquiry, Volume V, 28.)

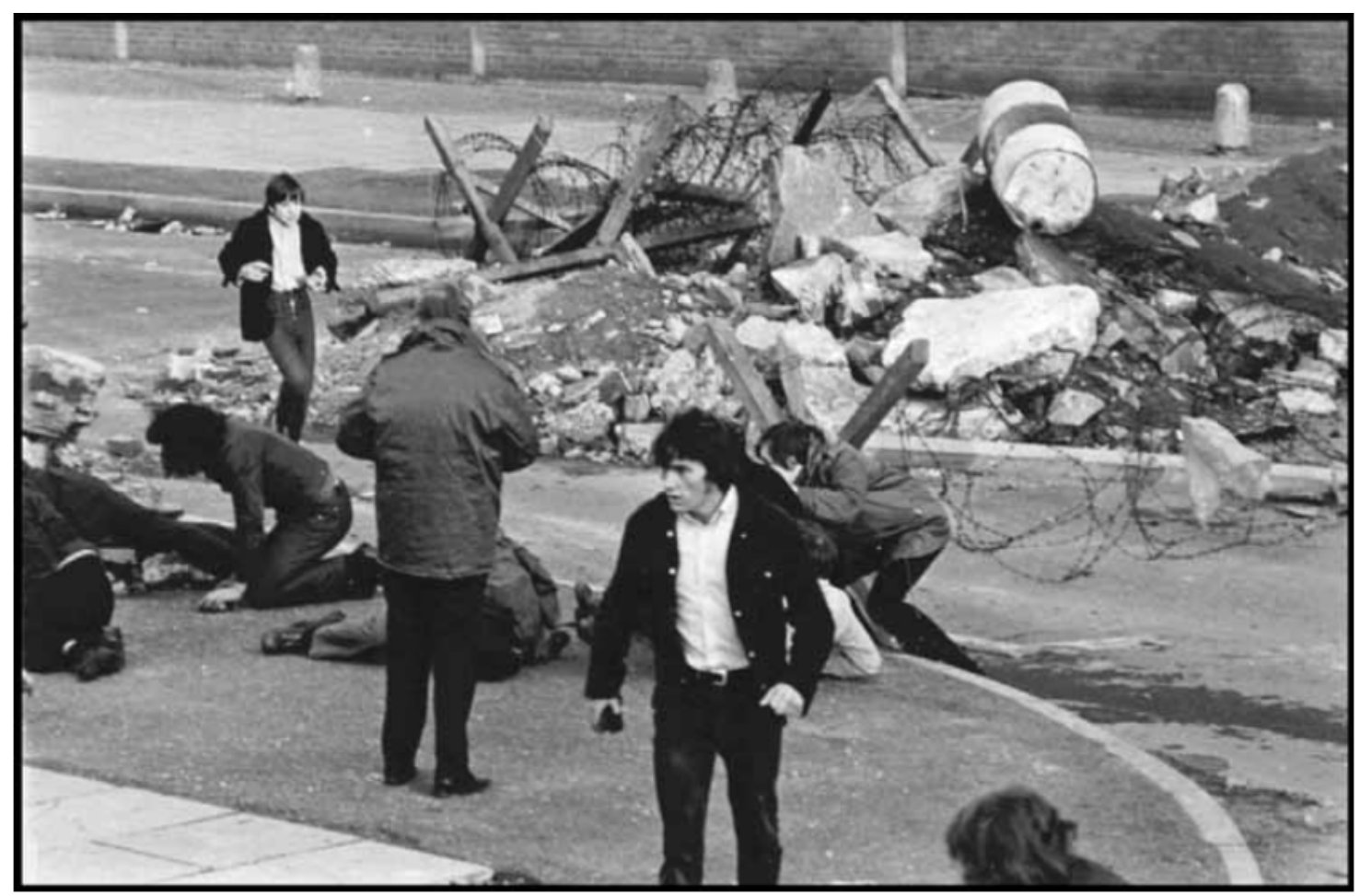

Figure 1.22. Photographs showing marchers and eventual riots near Barrier 14 in William Street (Source: Report of the Bloody Sunday Inquiry, Volume V, 30.) 


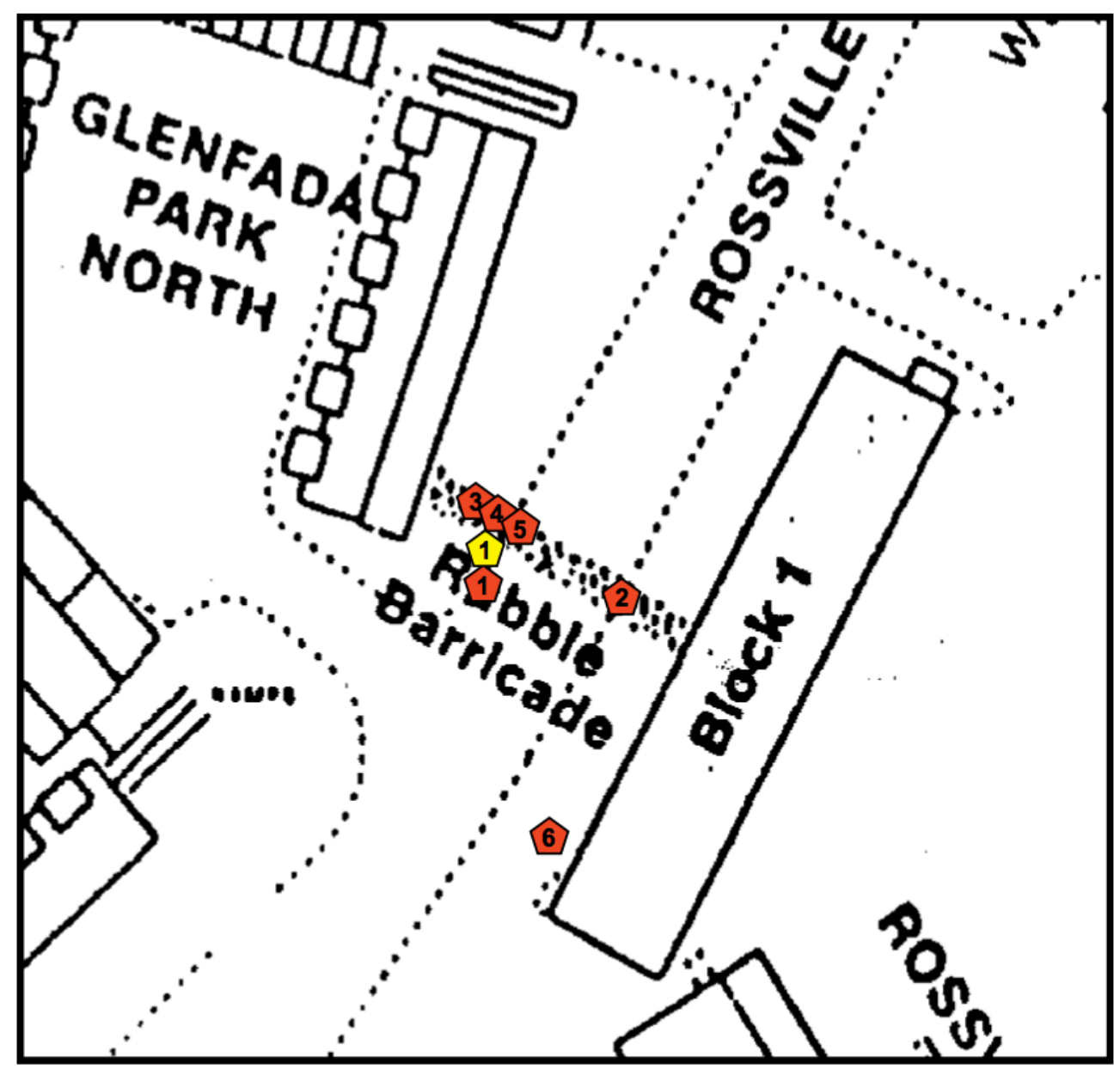

\begin{tabular}{|cl|}
\hline 1 & $\begin{array}{l}\text { Casualties who were killed or mortally wounded in the } \\
\text { area of the rubble barricade }\end{array}$ \\
2 & $\begin{array}{l}\text { Michael Kelly } \\
\text { Hugh Gilmour. The precise position at which this casualty } \\
\text { was shot is unknown. }\end{array}$ \\
$\mathbf{3}, \mathbf{4}$ and $\mathbf{5}$ & $\begin{array}{l}\text { Michael McDaid, William Nash and John Young. } \\
\text { William Nash was in the middle of the three but the precise } \\
\text { position of these casualties at the rubble barricade is not } \\
\text { known. } \\
6\end{array}$ \\
& Kevin McElhinney \\
1 & Casualty who was wounded in this area \\
& Alexander Nash \\
\hline
\end{tabular}

Figure 1.23. Map showing the Bloody Sunday casualties in the vicinity of the Rossville Street barricade (Source: Principal Conclusions and Overall Assessment of the Bloody Sunday Inquiry, 25.) 

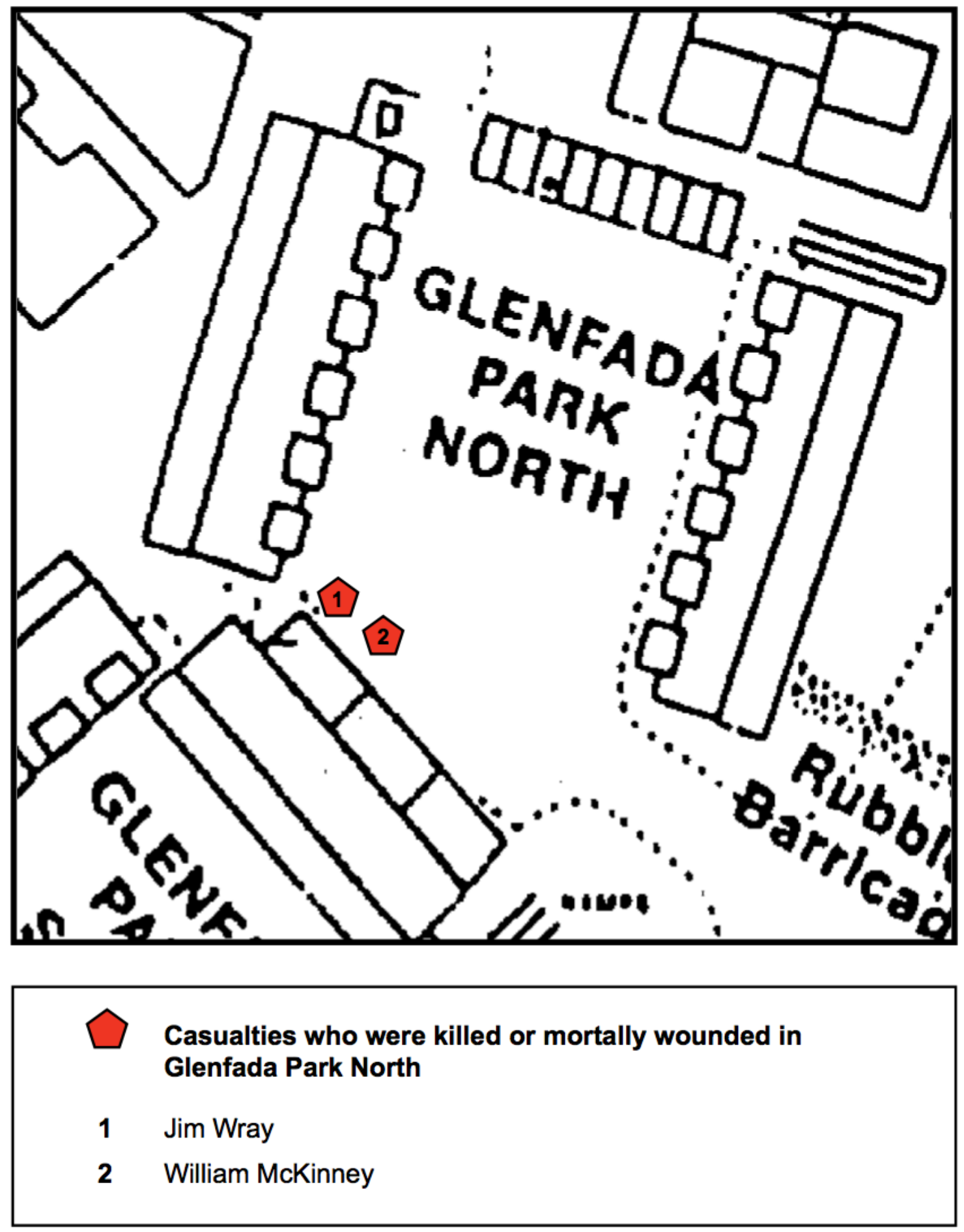

Figure 1.24. Map showing fatal casualties in Glenfada Park North during Bloody Sunday (Source: Principal Conclusions and Overall Assessment of the Bloody Sunday Inquiry, 26.) 


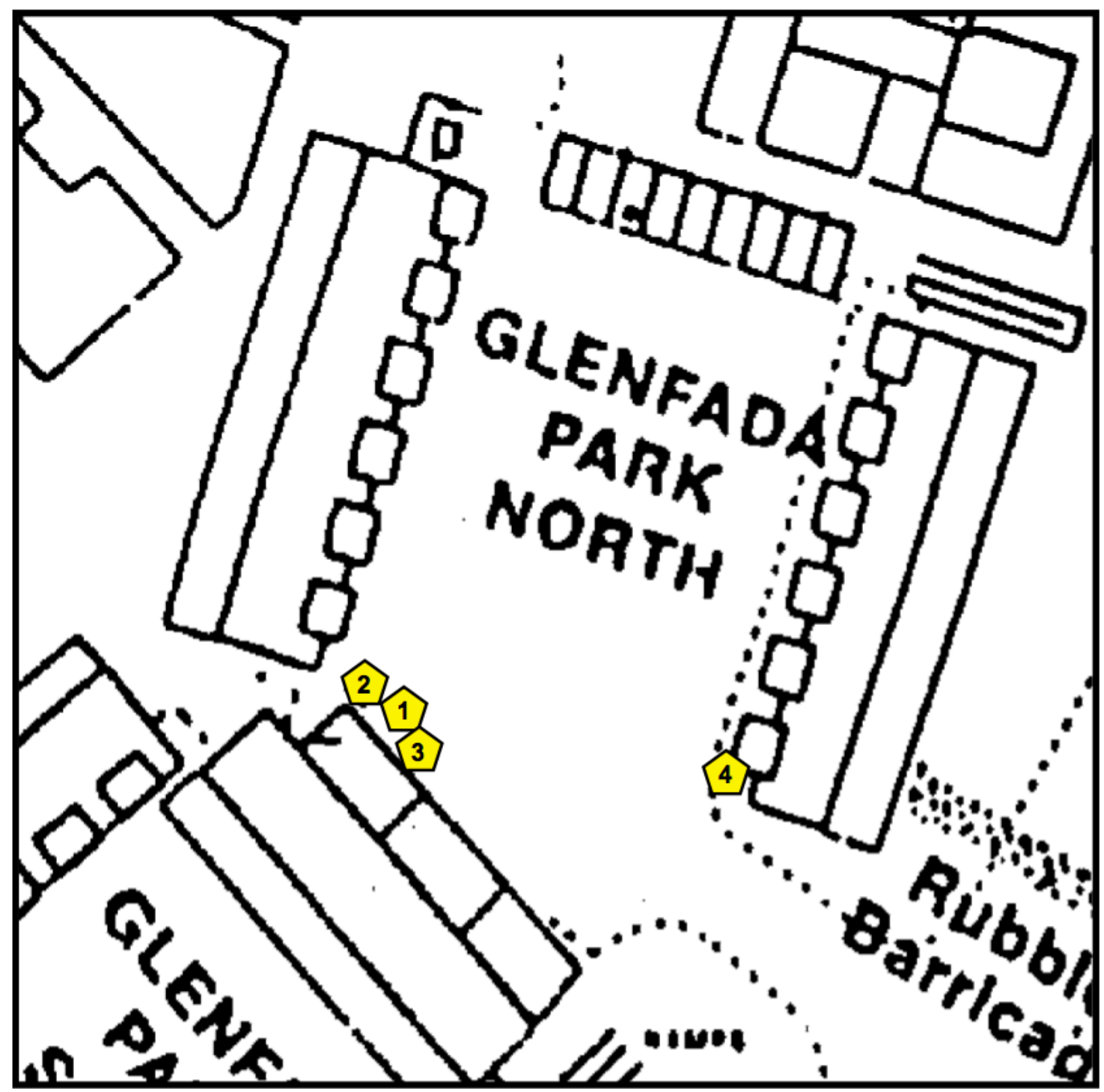

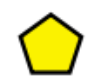
1 Michael Quinn
3 Joe Mahon
2 Joe Friel
4 Patrick O'Donnell

Casualties who were wounded in Glenfada Park North

Figure 1.25. Map showing other injuries in Glenfada Park North during Bloody Sunday

(Source: Principal Conclusions and Overall Assessment of the Bloody Sunday Inquiry, 27.) 


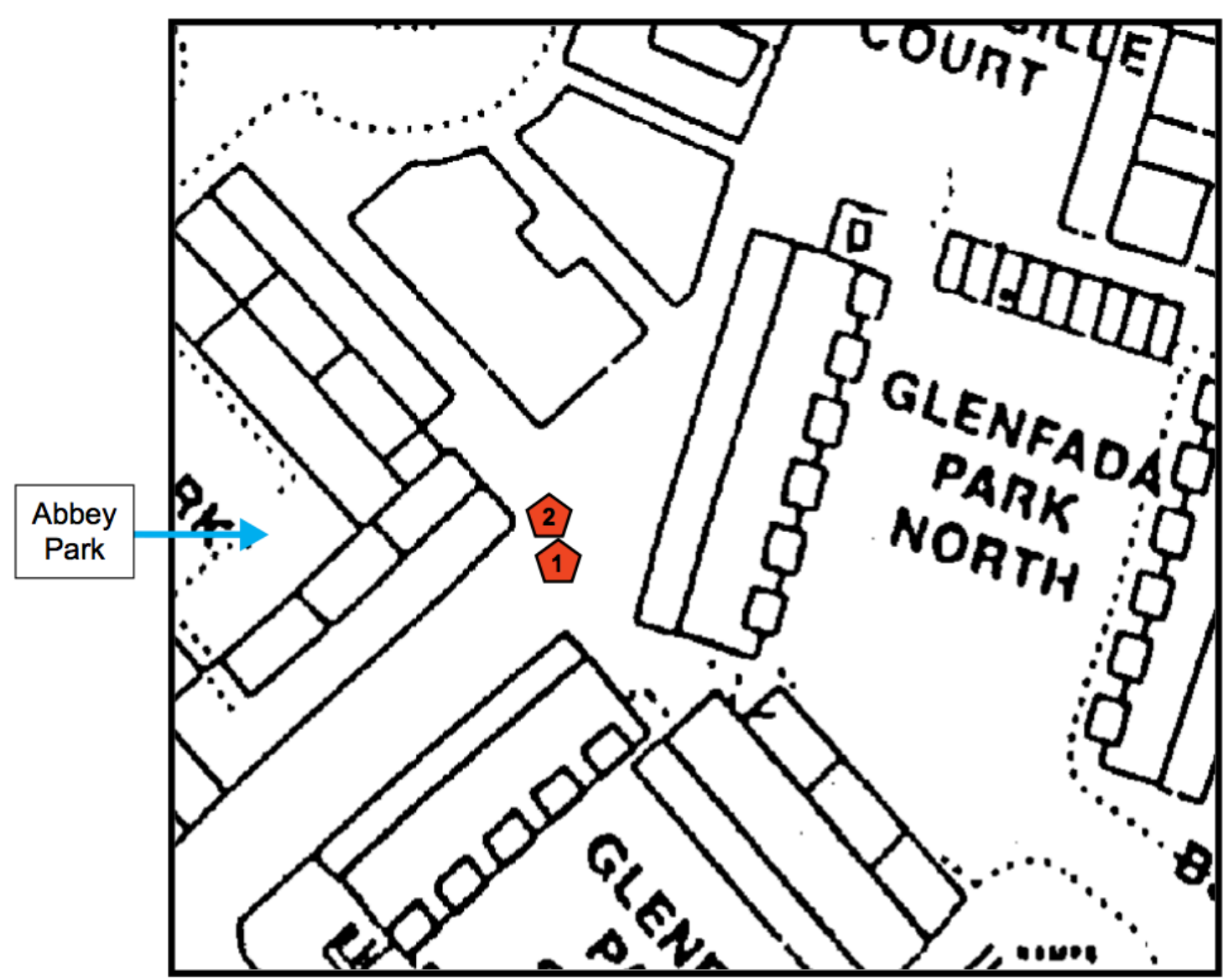

Casualties who were killed or mortally wounded in Abbey Park

1 Gerard McKinney

2 Gerald Donaghey

Figure 1.26. Map showing the Bloody Sunday casualties near Abbey Park, just past Glenfada Park North (Source: Principal Conclusions and Overall Assessment of the Bloody Sunday Inquiry, 31.) 


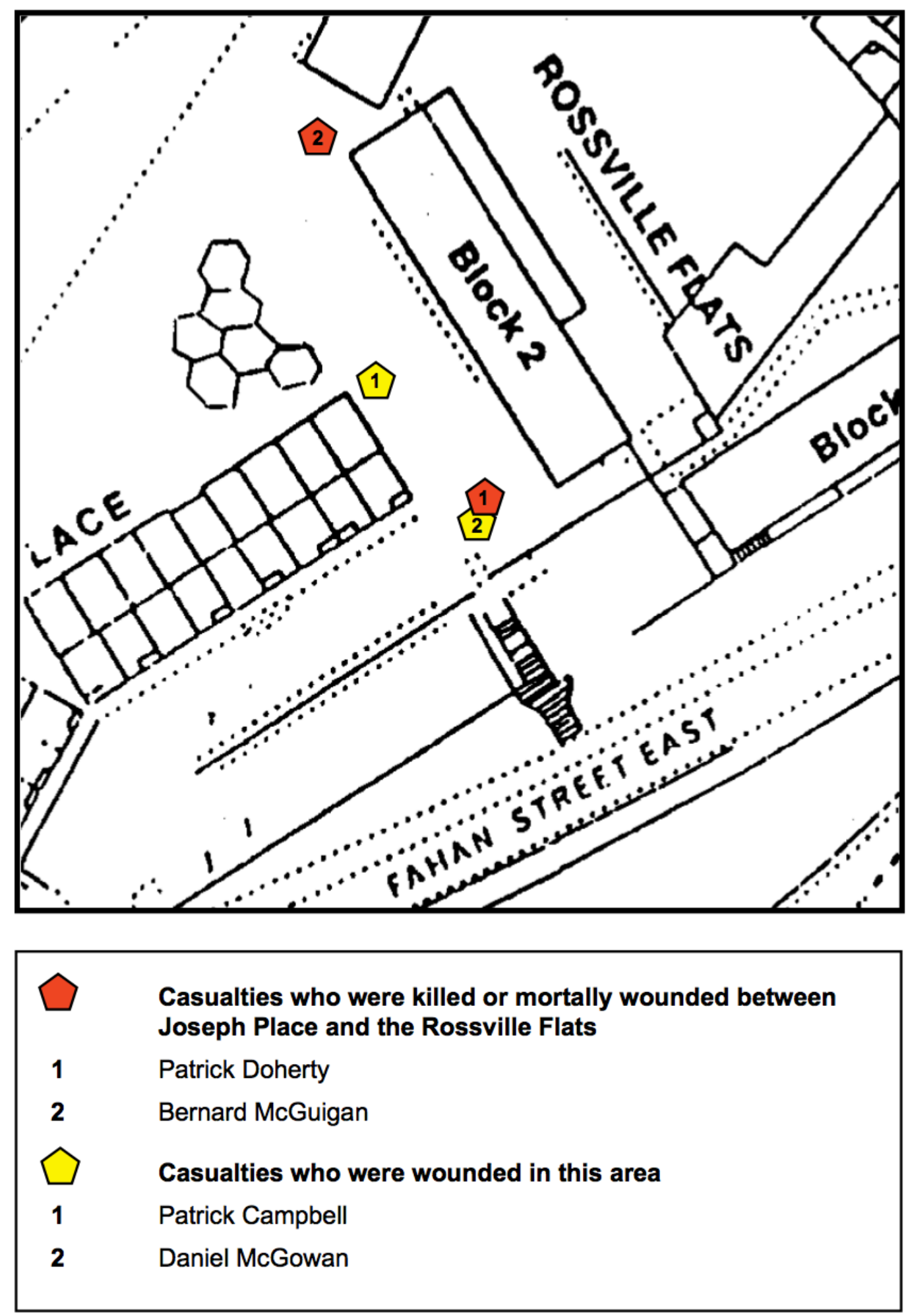

Figure 1.27. Map showing the final Bloody Sunday casualties between Joseph Place and Rossville Flats (Source: Principal Conclusions and Overall Assessment of the Bloody Sunday Inquiry, 31.) 


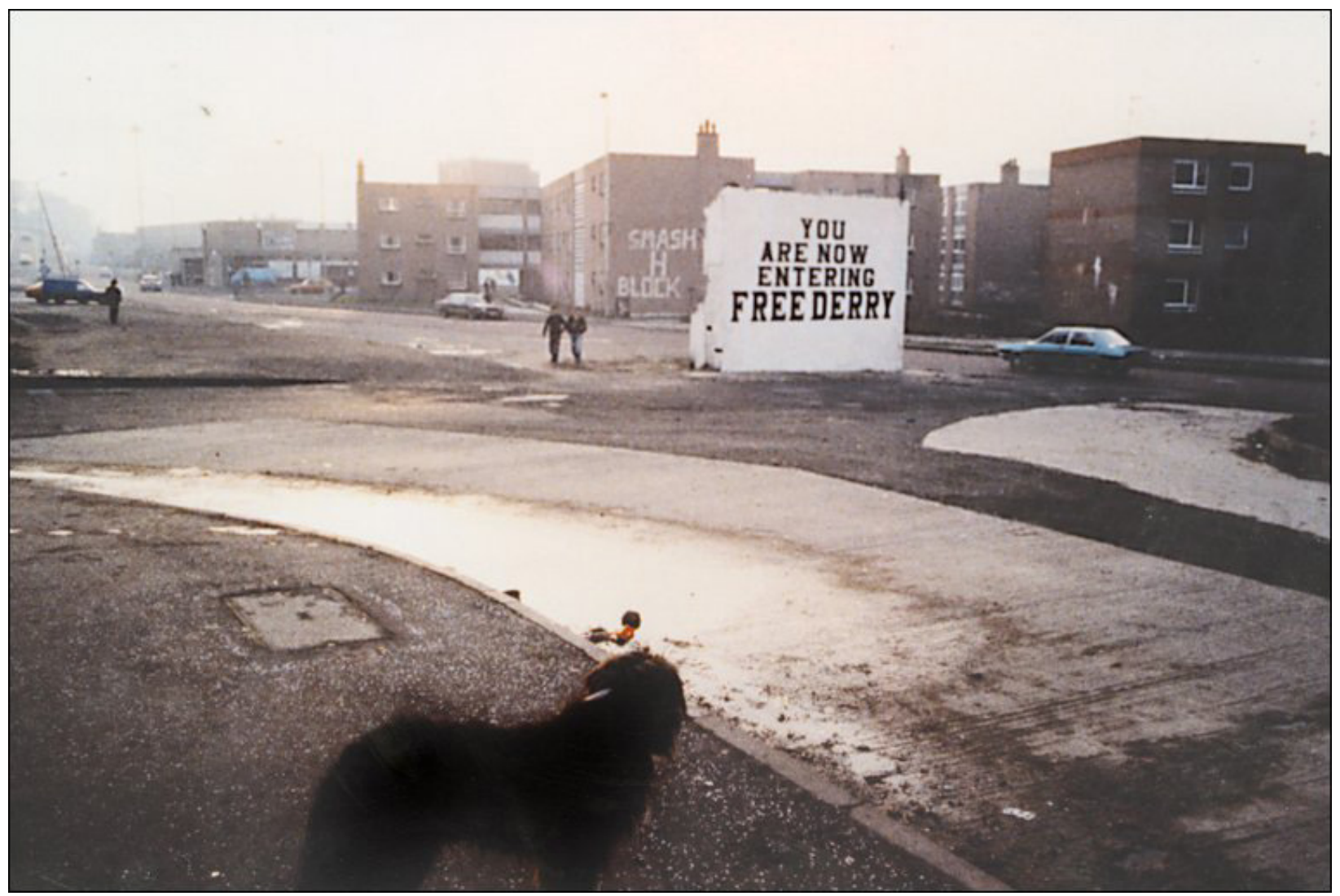

Figure 2.1. Photograph showing Free Derry Corner following IRA demolition, 1974 (Source: Shea, p.390) 


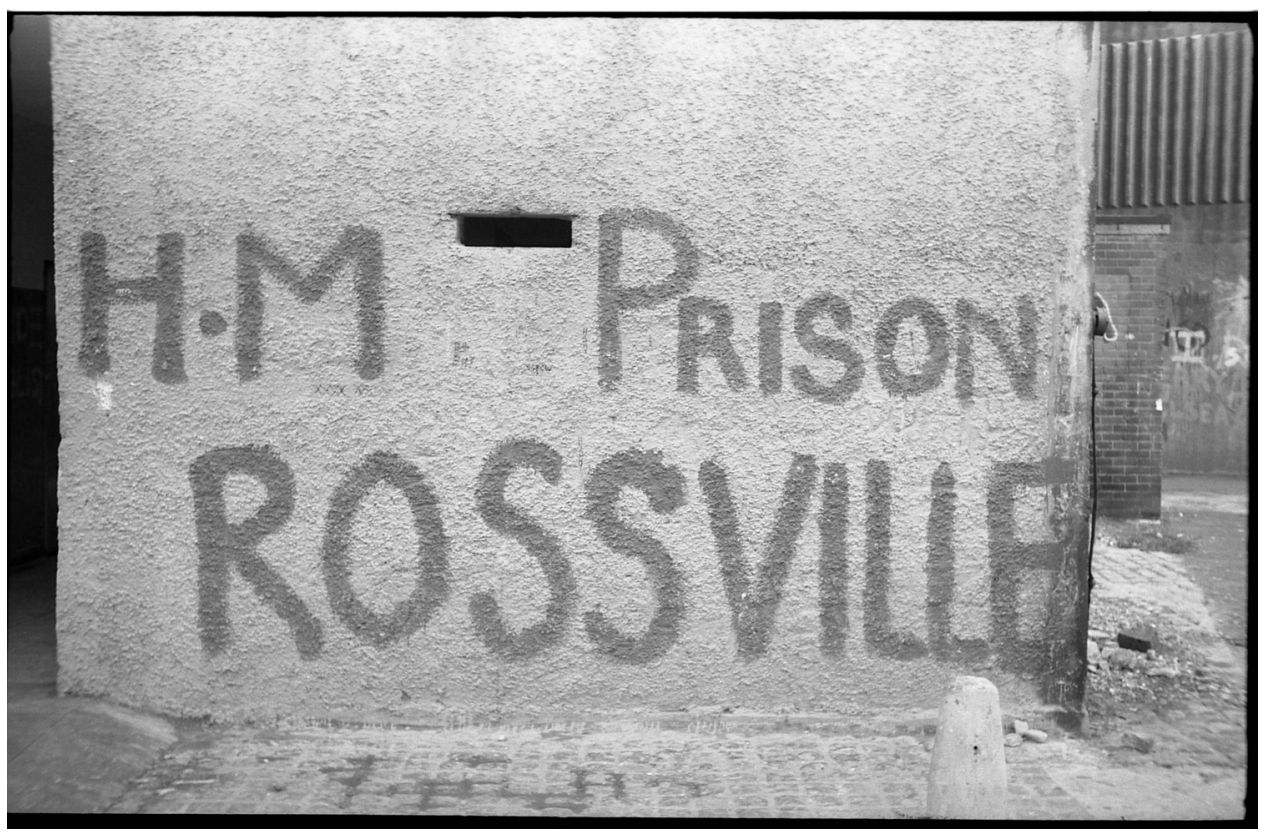

Figure 2.2. 1982 photograph showing early Republican graffiti on walls of the Rossville Flats (Source: Tony Crowley; Murals of Northern Ireland archive, Claremont Colleges Digital Library)

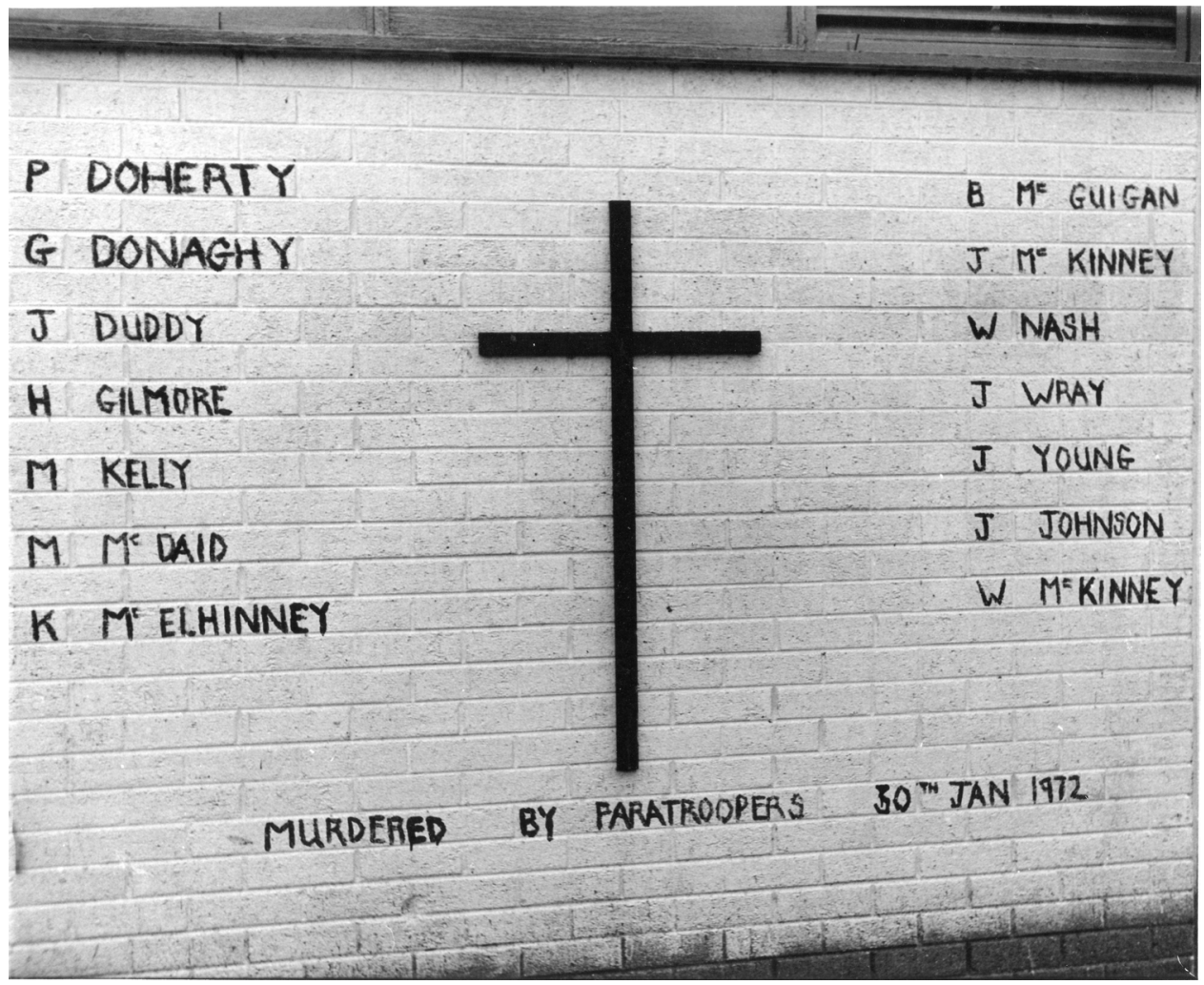

Figure 2.3. 1981 photograph of a Republican mural in Rossville Flats commemorating Bloody Sunday deaths (Source: Tony Crowley; Murals of Northern Ireland archive, Claremont Colleges Digital Library) 


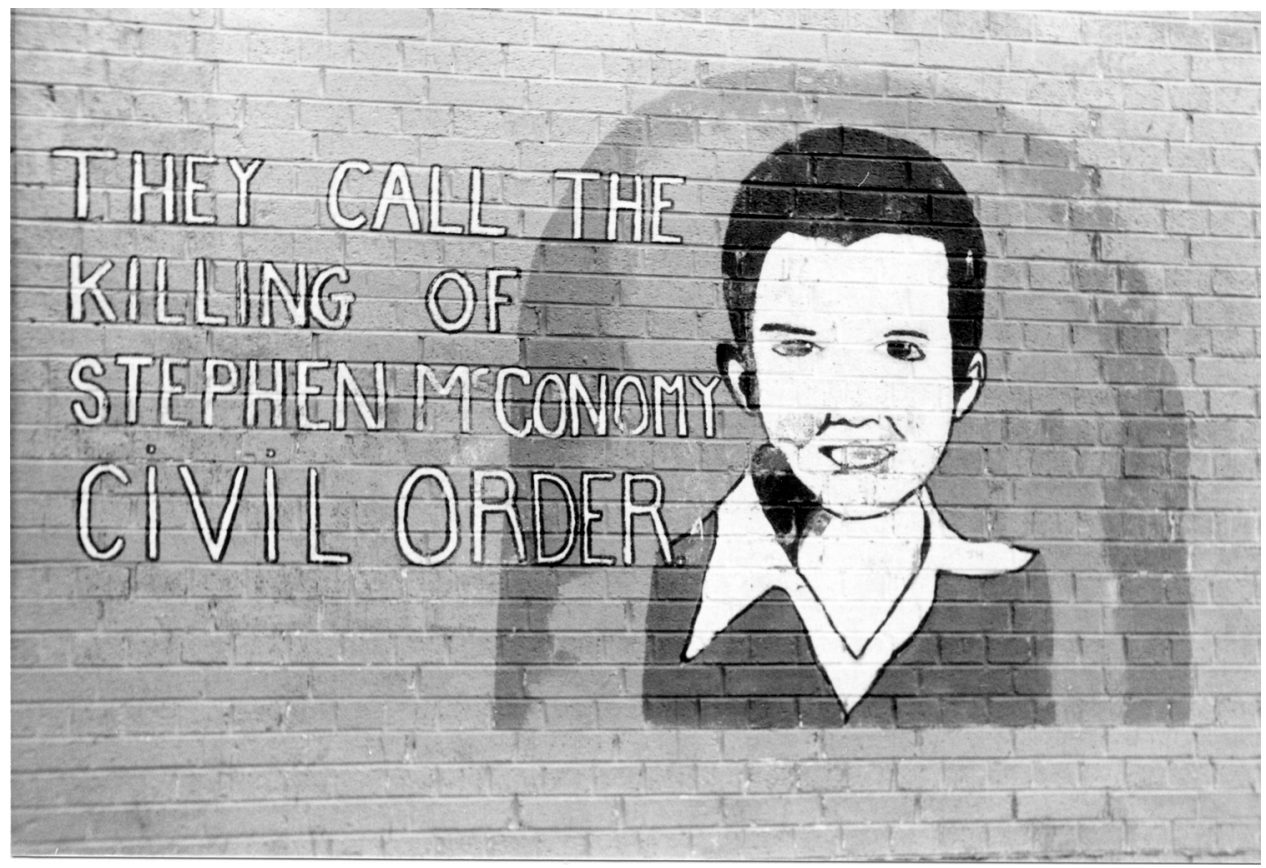

Figure 2.4. 1982 photograph of a Republican mural in Rossville Flats commemorating the April 1982 shooting death of Stephen McConomy (Source: Tony Crowley; Murals of Northern Ireland archive, Claremont Colleges Digital Library)

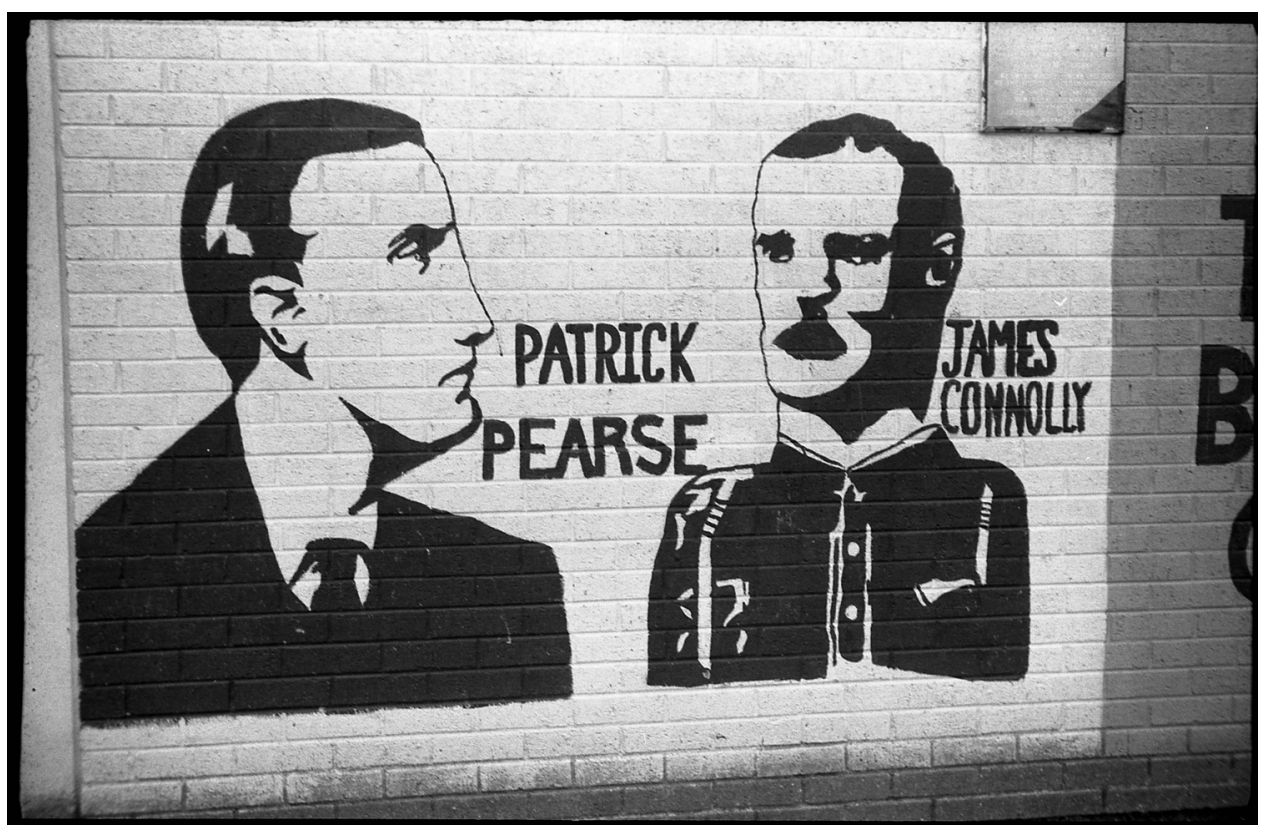

Figure 2.5. 1981 photograph of a Republican mural depicting James Connolly and Patrick Pearse, leaders during the failed 1916 Easter Rebellion (Source: Tony Crowley; Murals of Northern Ireland archive, Claremont Colleges Digital Library) 


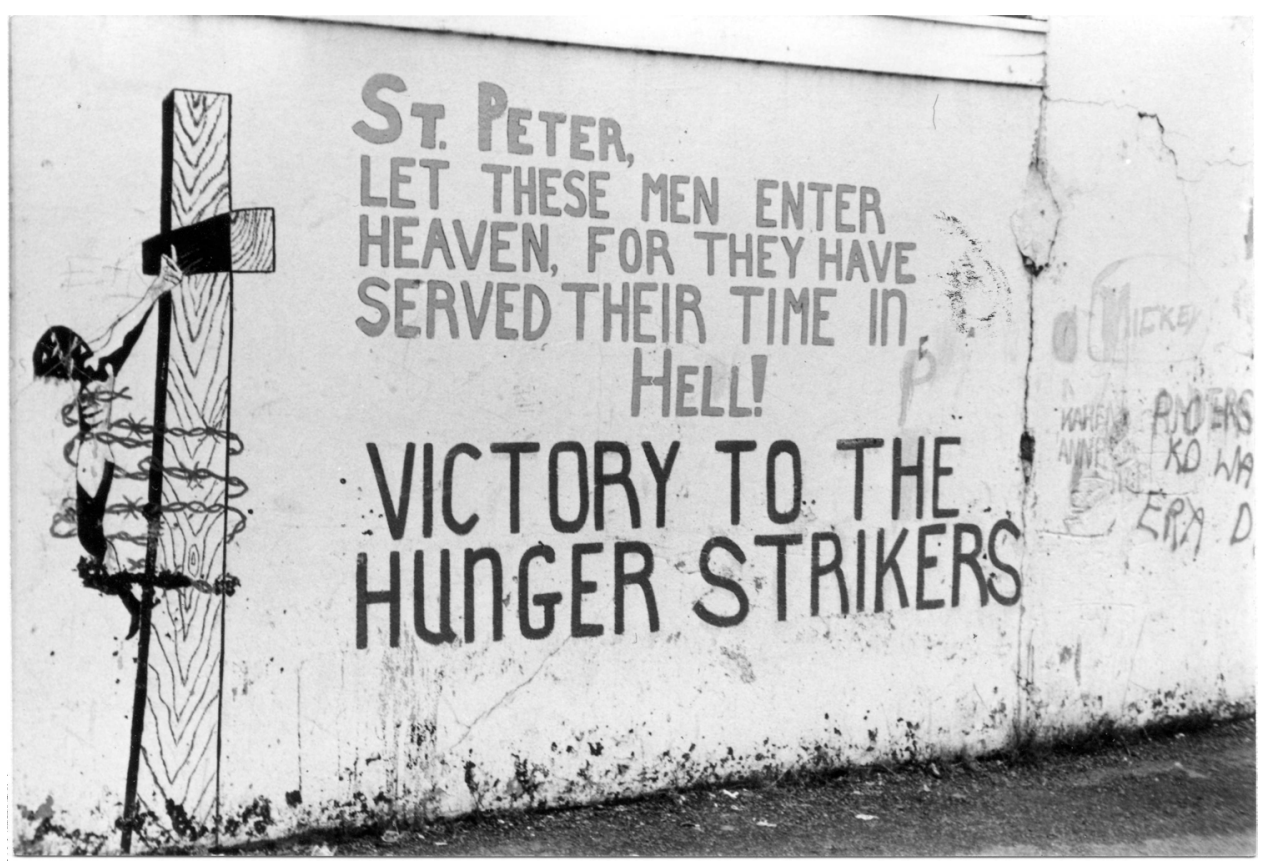

Figure 2.6. 1981 photograph of a Republican mural depicting support for ongoing hunger strikes (Source: Tony Crowley; Murals of Northern Ireland archive, Claremont Colleges Digital Library)

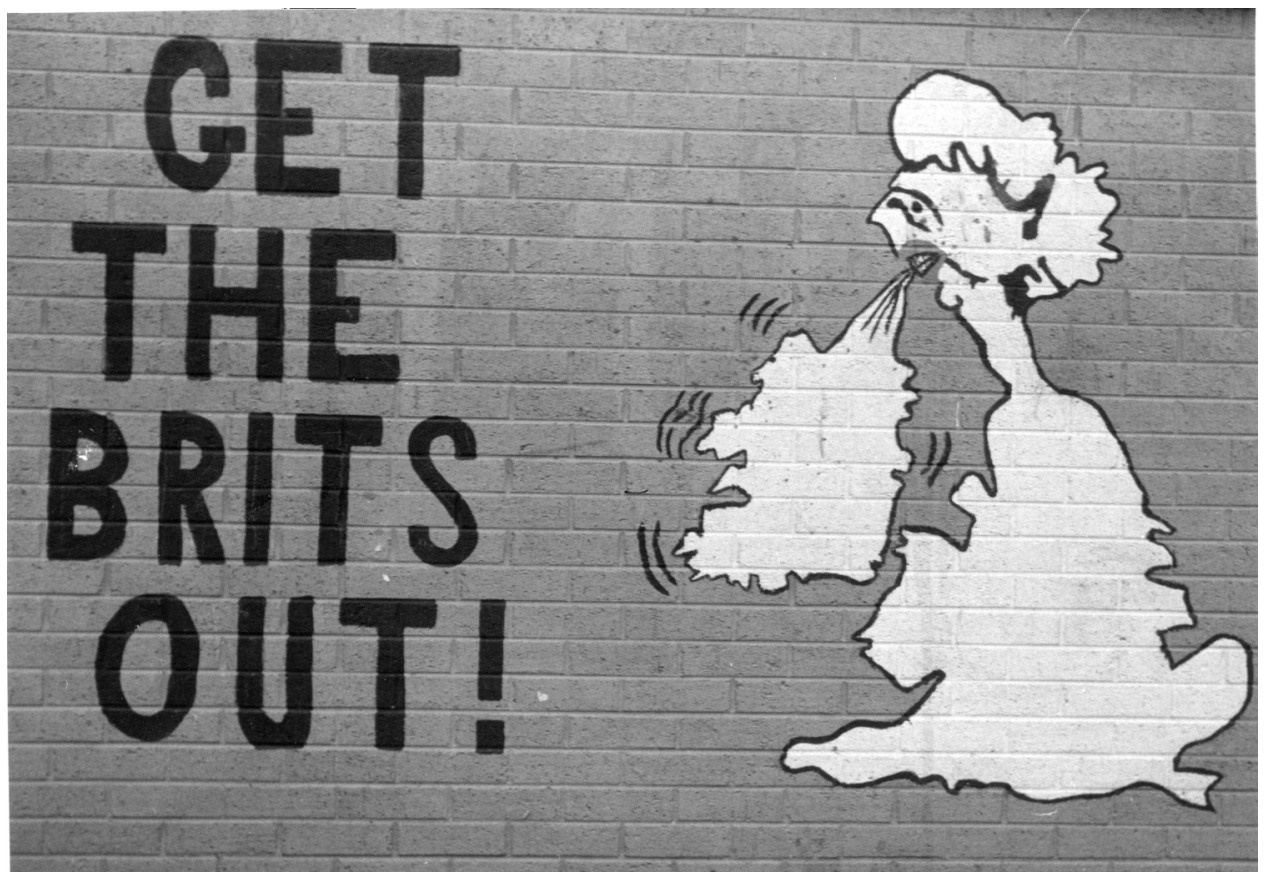

Figure 2.7. 1981 photograph of a Republican mural depicting anti-British, anti-Thatcher message and imagery (Source: Tony Crowley; Murals of Northern Ireland archive, Claremont Colleges Digital Library) 


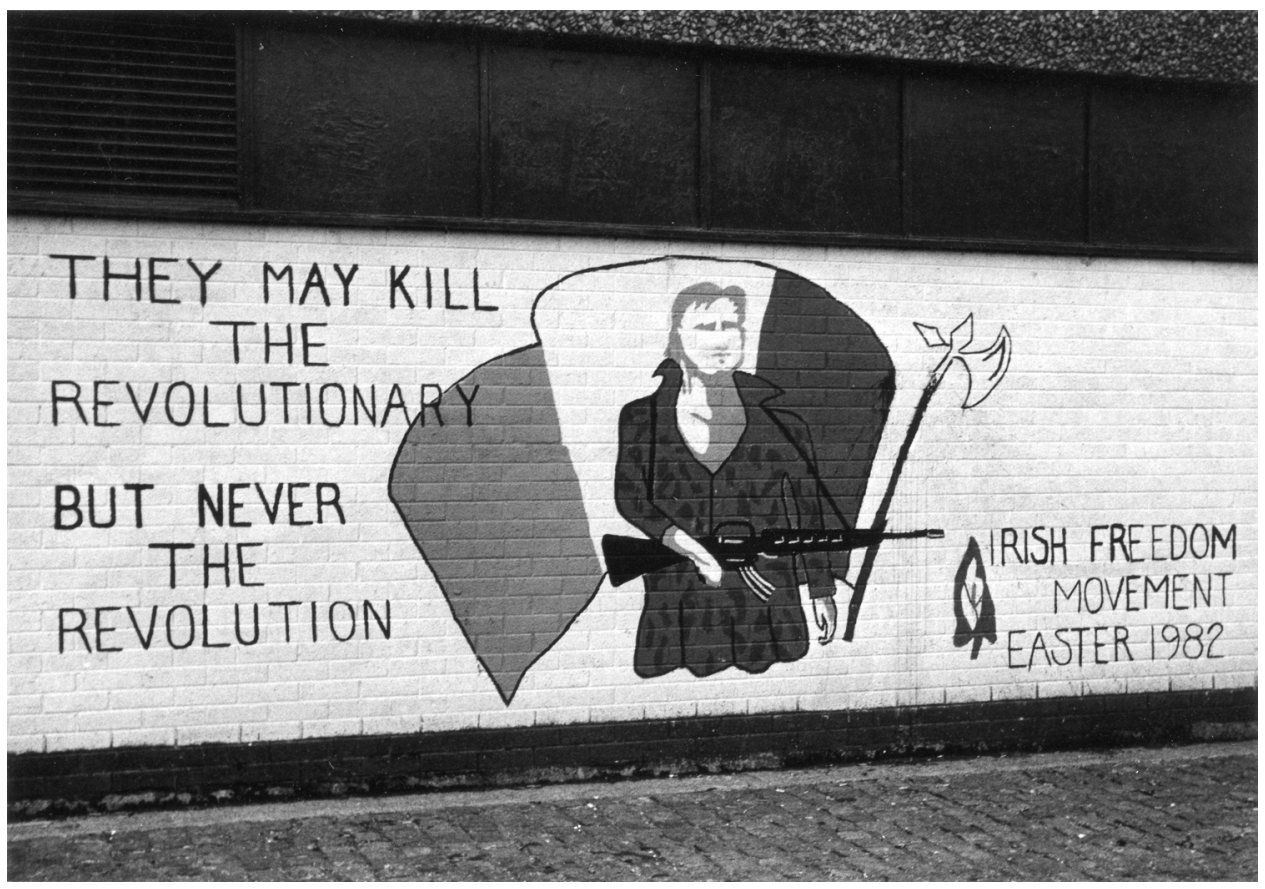

Figure 2.8. 1981 photograph of a Republican mural depicting a paramilitary silhouette alongside the Irish tricolour (Source: Tony Crowley; Murals of Northern Ireland archive, Claremont Colleges Digital Library)

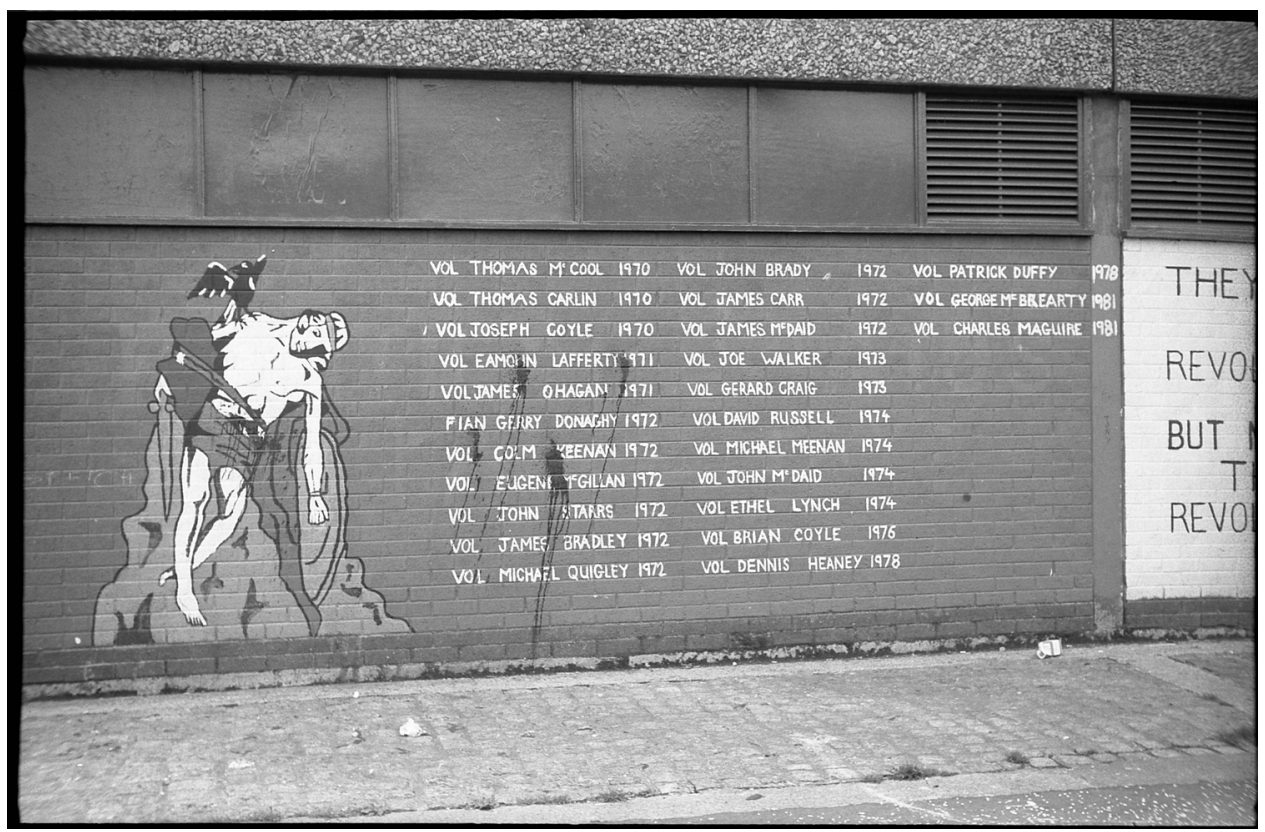

Figure 2.9. 1981 photograph of a Republican mural depicting an honor roll for deceased local IRA volunteers alongside traditional Gaelic imagery (Source: Tony Crowley; Murals of Northern Ireland archive, Claremont Colleges Digital Library) 


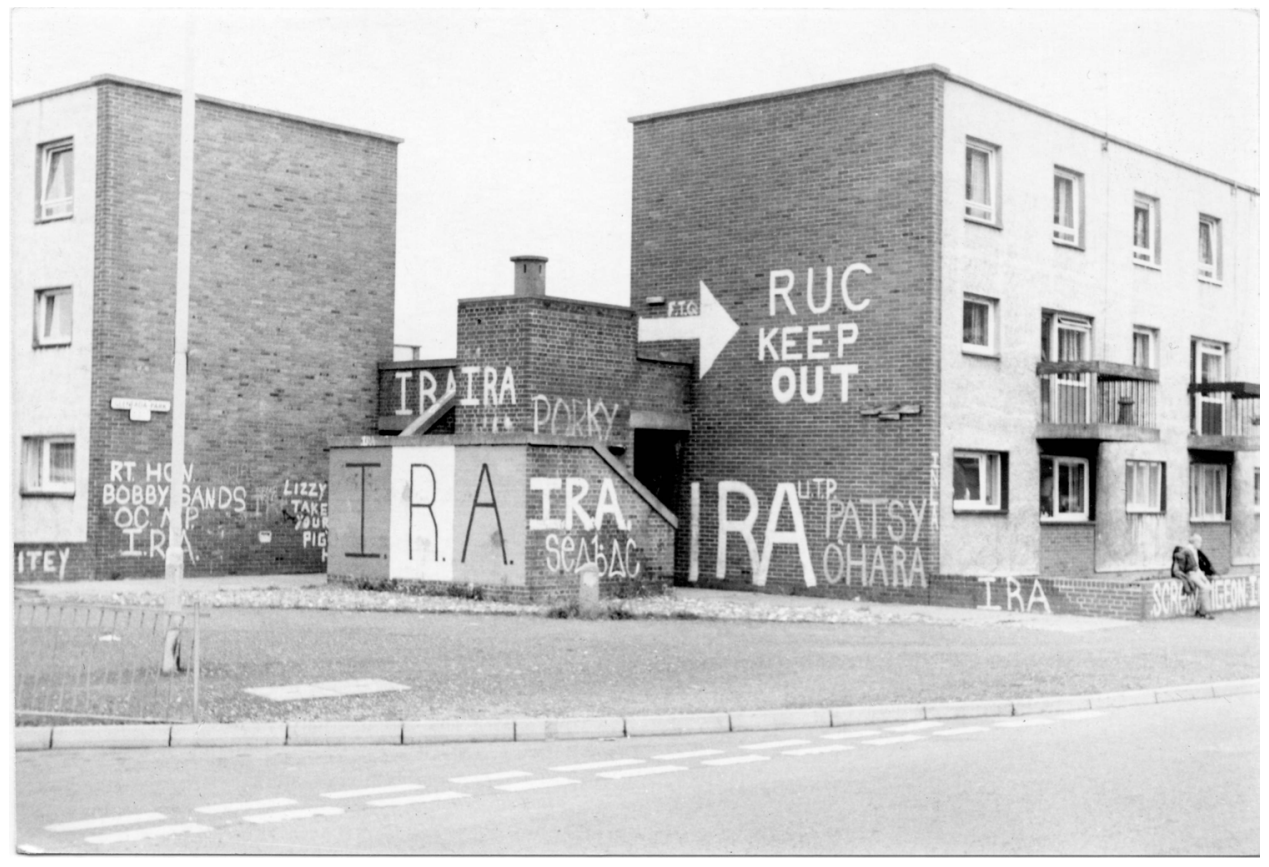

Figure 2.10. 1983 photograph of a Republican murals/graffiti at Glenfada Park showing support for the IRA alongside anti-police messages (Source: Tony Crowley; Murals of Northern Ireland archive, Claremont Colleges Digital Library)

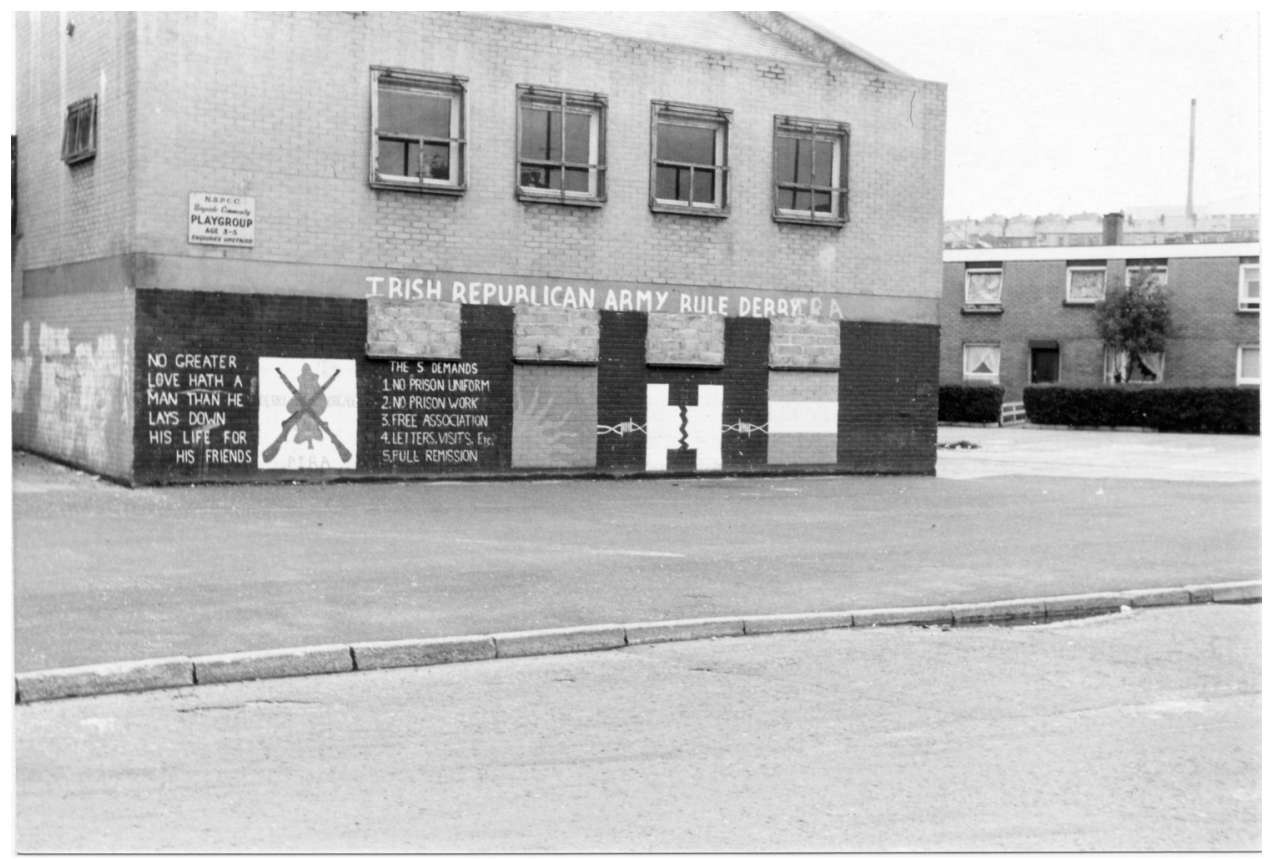

Figure 2.11. 1983 photograph of a Republican mural on Westland St. depicting support for the political demands of imprisoned hunger strikers (Source: Tony Crowley; Murals of Northern Ireland archive, Claremont Colleges Digital Library) 


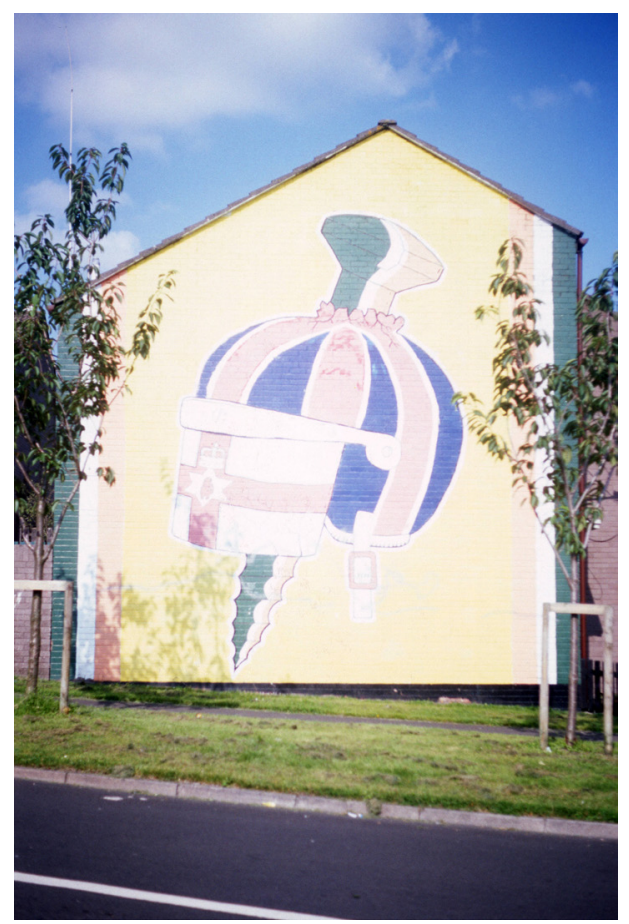

Figure 2.12. 1995 photograph of a Republican mural on Foyle Rd. depicting threatening imagery directed at the RUC (Source: Tony Crowley; Murals of Northern Ireland archive, Claremont Colleges Digital Library)

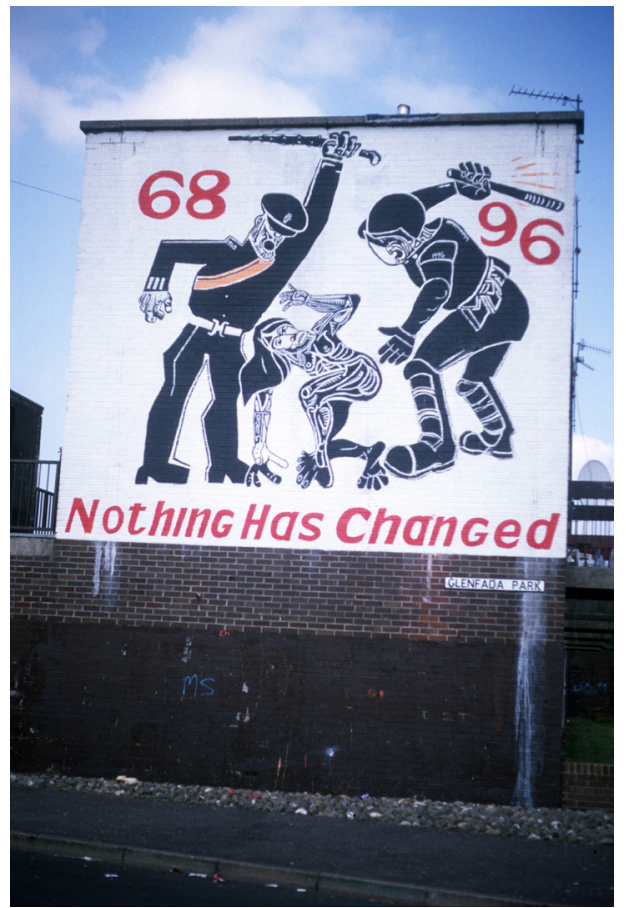

Figure 2.13. 1996 photograph of a Republican mural in Glenfada Park depicting sustained republican mistreatment at the hands of the RUC (Source: Tony Crowley; Murals of Northern Ireland archive, Claremont Colleges Digital Library) 


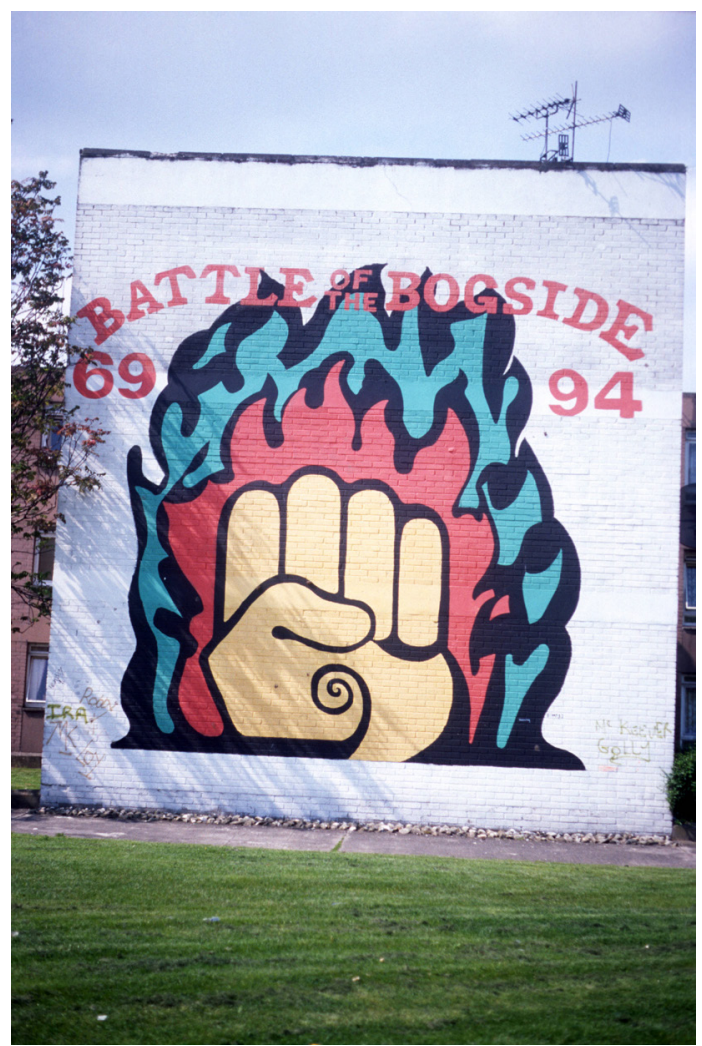

Figure 2.14. 1994 photograph of a Republican mural on Fahan St. commemorating the Battle of the Bogside (Source: Tony Crowley; Murals of Northern Ireland archive, Claremont Colleges Digital Library)

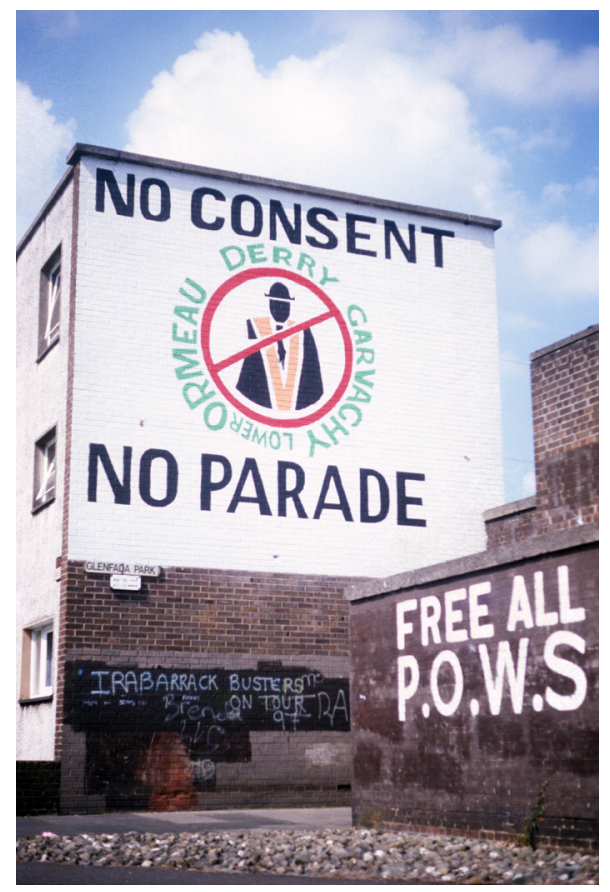

Figure 2.15. 1996 photograph of a Republican mural in Glenfada Park protesting the continued antagonism of annual loyalist marches (Source: Tony Crowley; Murals of Northern Ireland archive, Claremont Colleges Digital Library) 

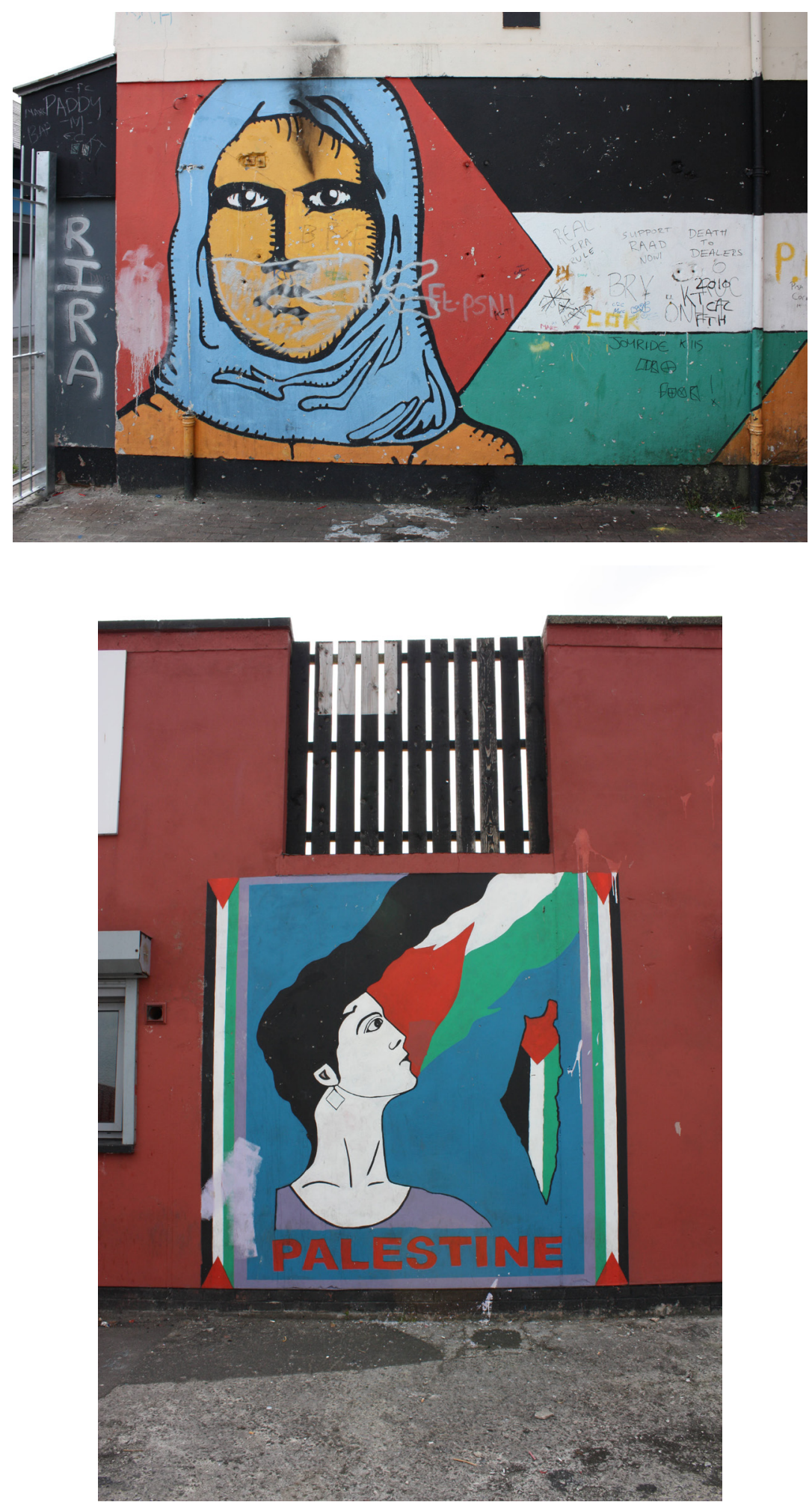

Figure 2.16. 2010 photographs of a Republican murals along Lecky Rd. and in Glenfada Park depicting solidarity with Palestine (Source: Tony Crowley; Murals of Northern Ireland archive, Claremont Colleges Digital Library) 


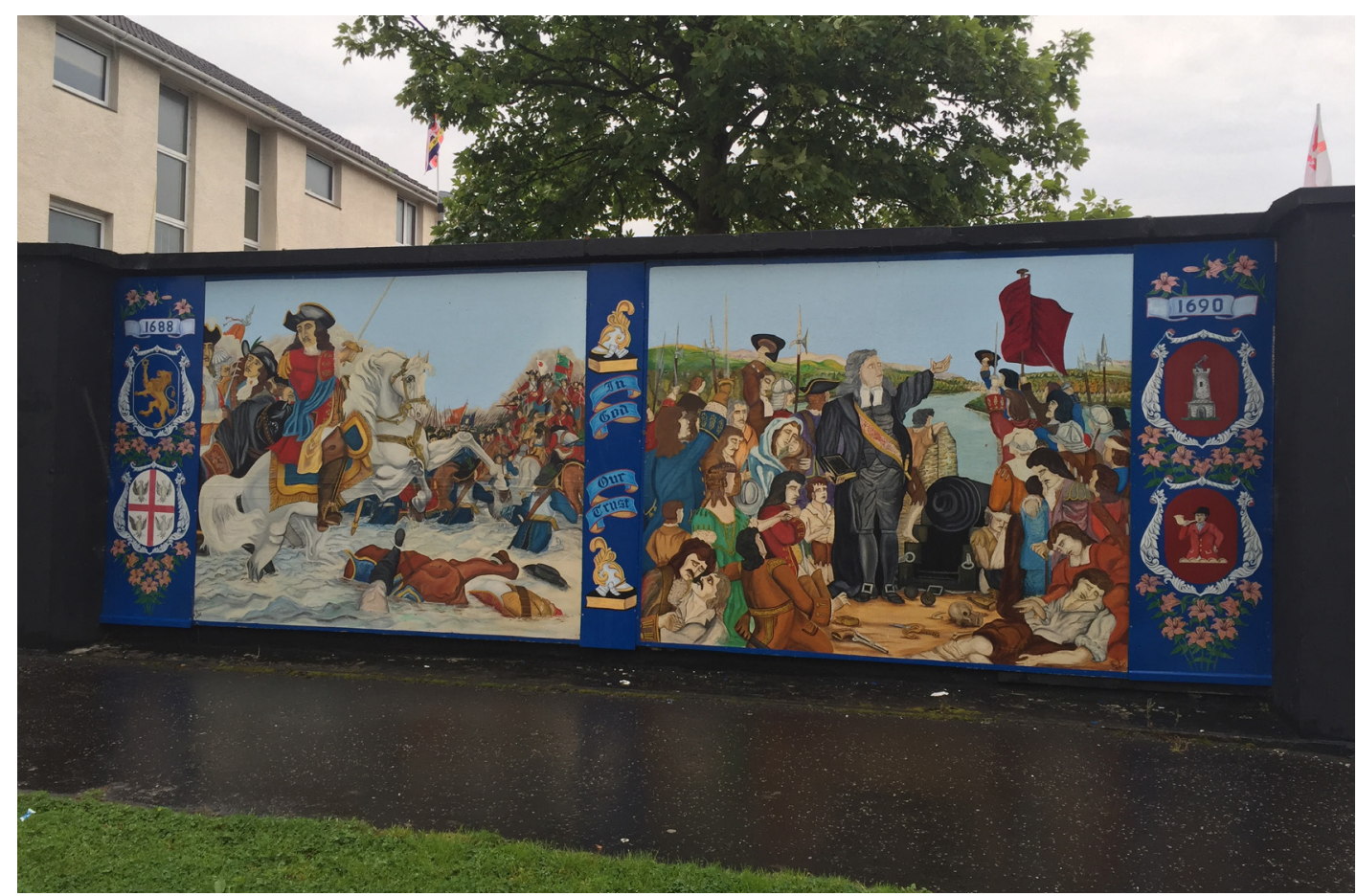

Figure 2.17. Photograph of the Loyalist "King Billy" mural within the Fountain neighborhood, August 2016 (Photograph taken by author)

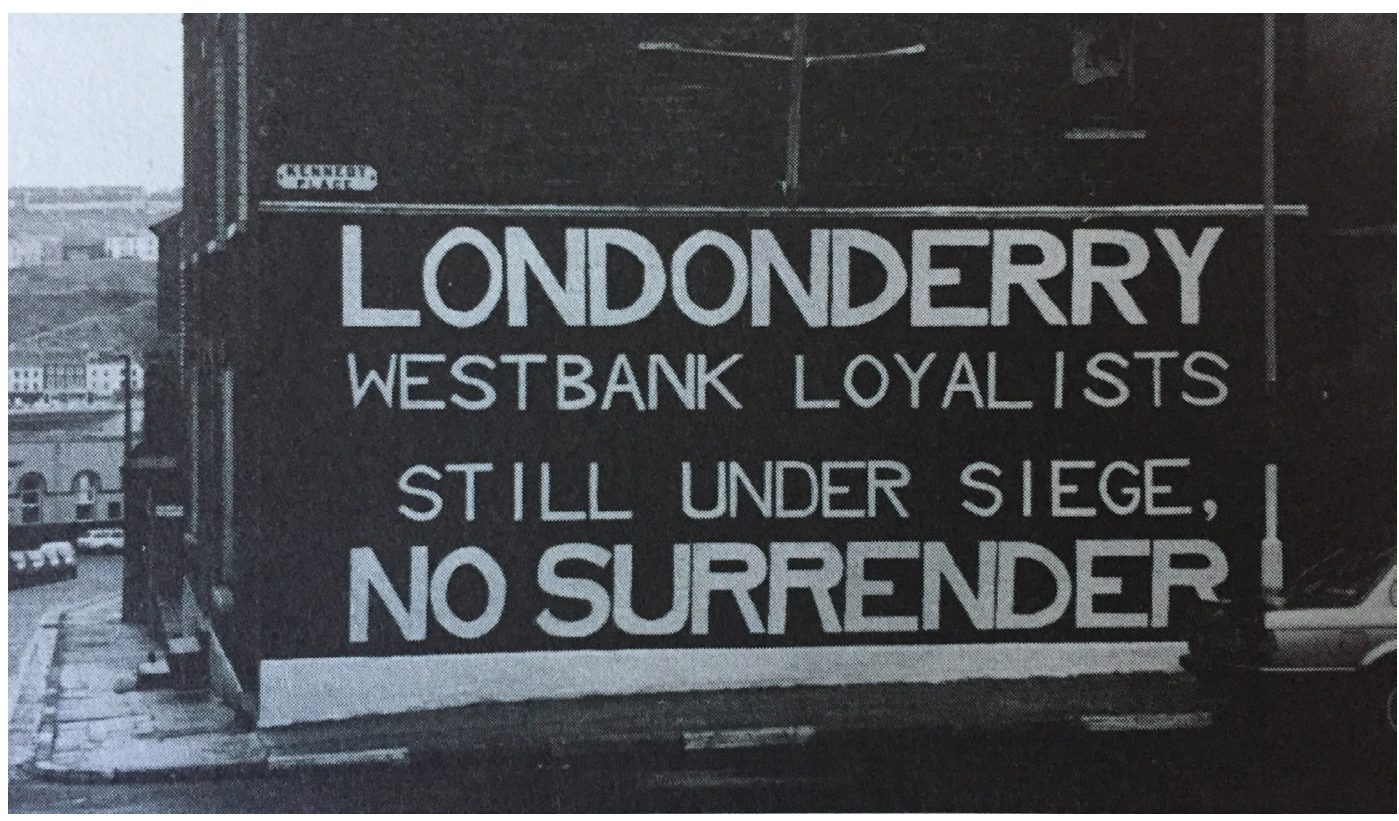

Figure 2.18. Photograph showing the Loyalist "No Surrender" mural within the Fountain neighborhood, circa 1987 (Source: Rolston, Politics and Painting (1991), p.43) 


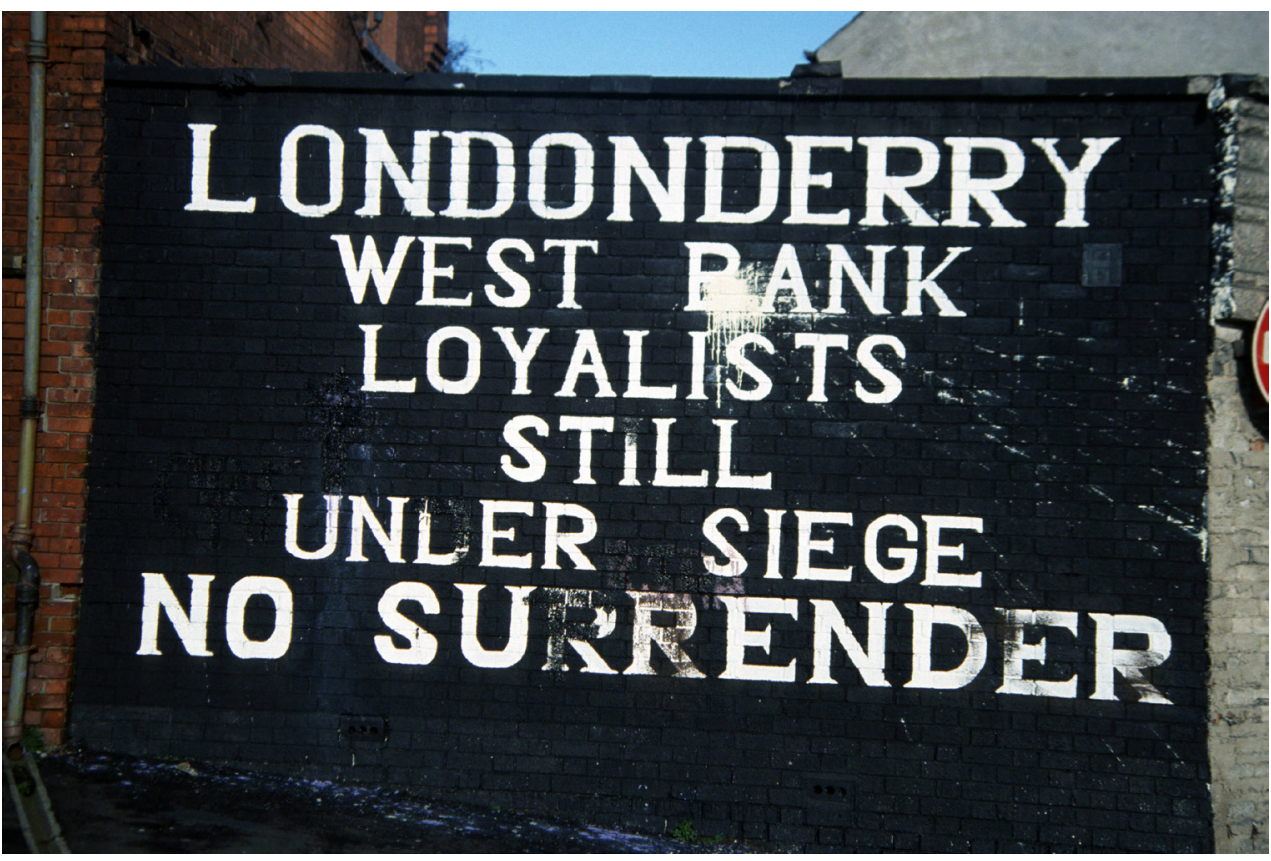

Figure 2.19. Photograph showing the Loyalist "No Surrender" mural within the Fountain neighborhood, circa 2000 (Source: Tony Crowley; Murals of Northern Ireland archive, Claremont Colleges Digital Library)

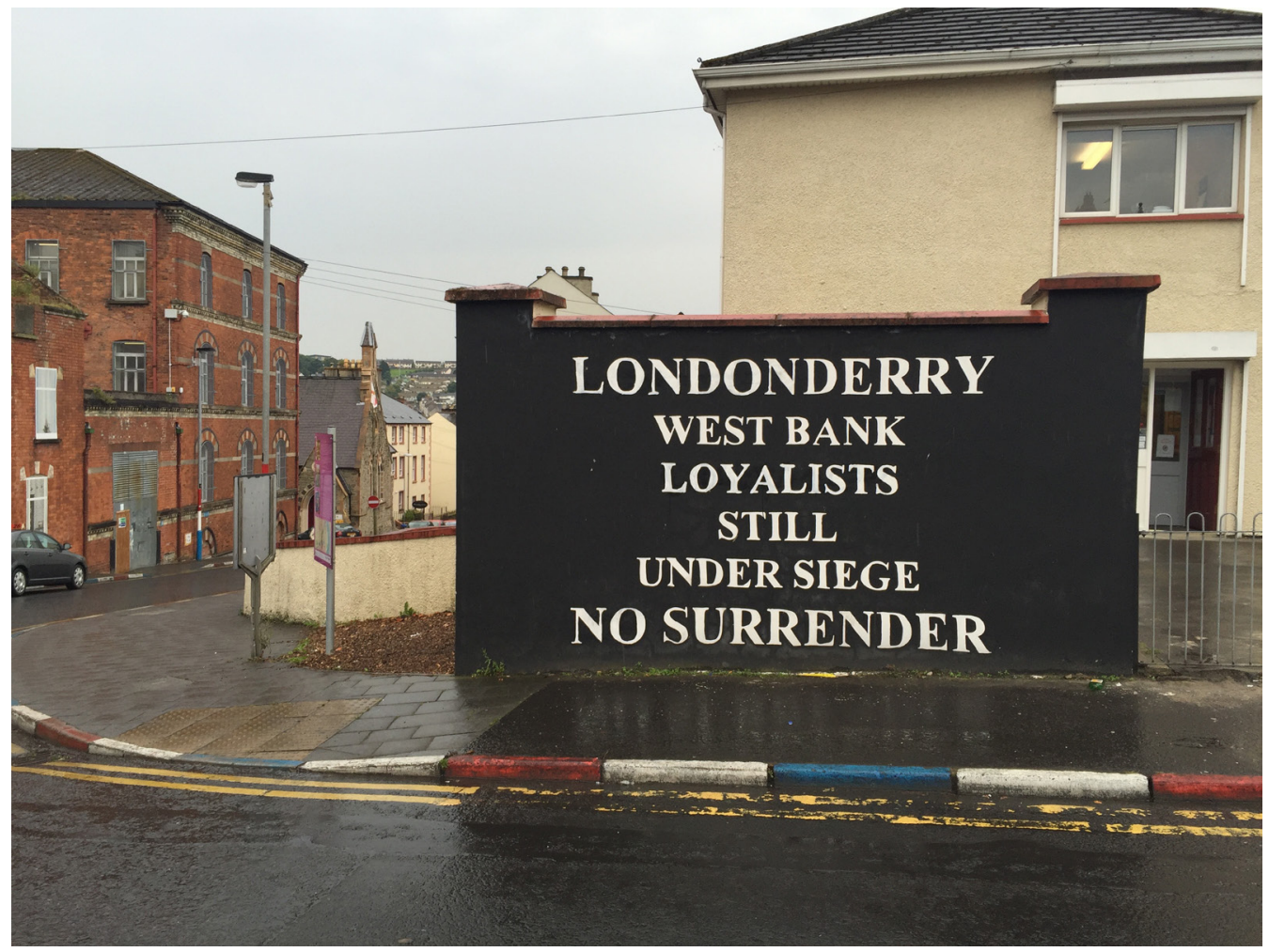

Figure 2.20. Photograph showing the Loyalist "No Surrender" mural within the Fountain neighborhood, circa August 2016 (Photograph taken by author) 


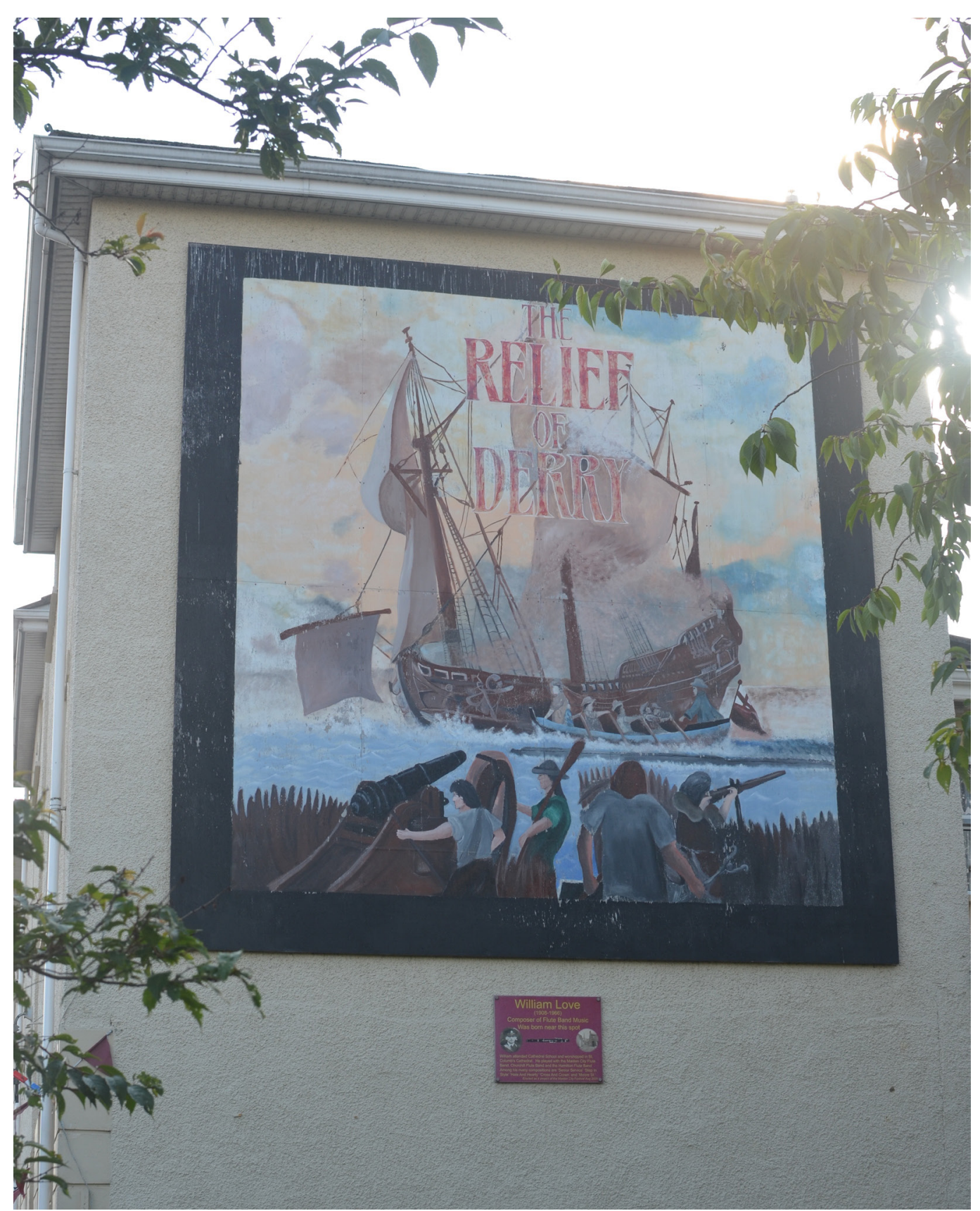

Figure 2.21. Loyalist mural in the Fountain commemorating the Relief of Derry during the siege of the city in 1689, August 2016 (Photograph taken by author) 


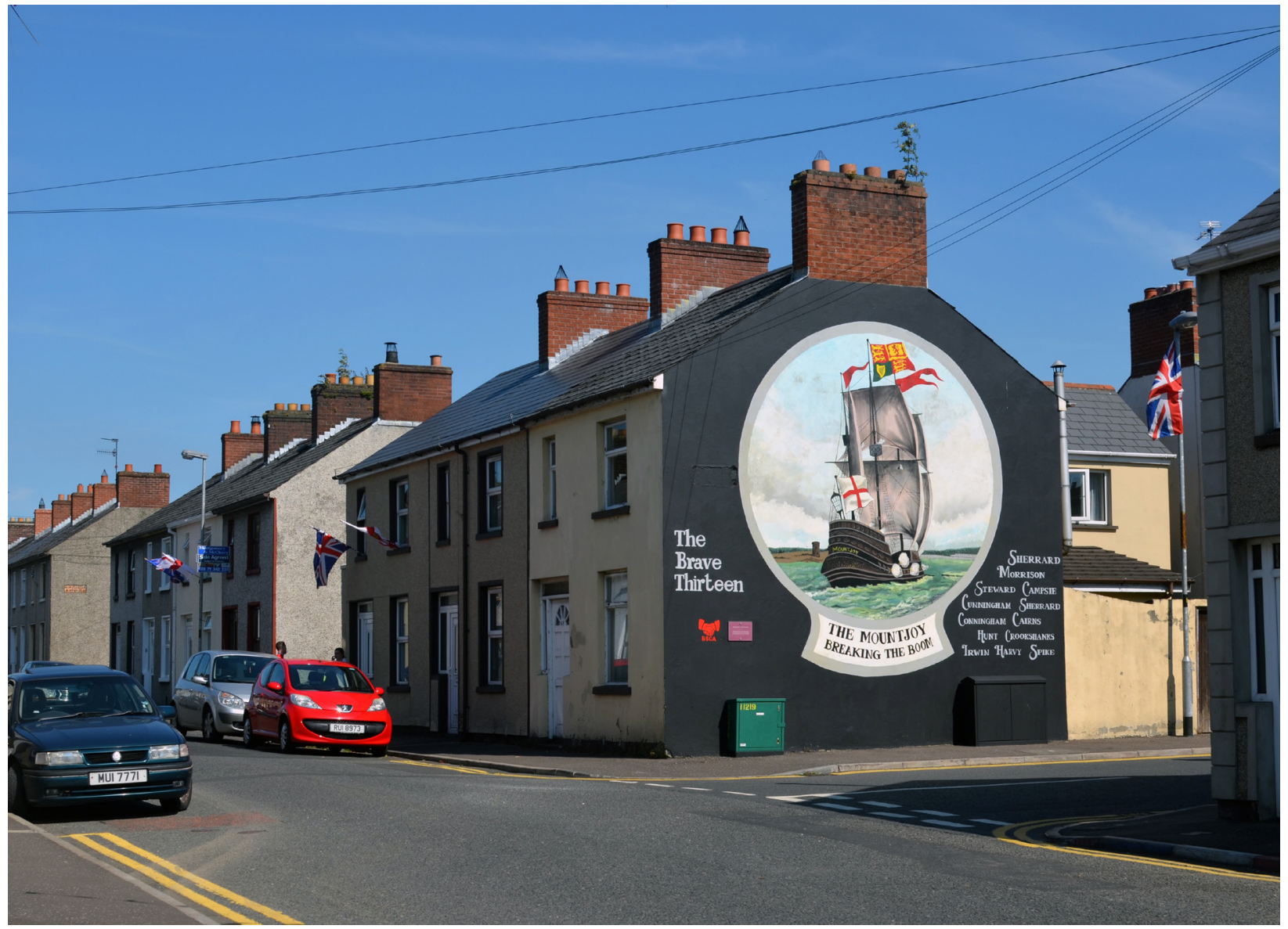

Figure 2.22. Loyalist mural in the Waterside commemorating the Protestant victory during the Siege of Derry in 1689, August 2016 (Photograph taken by author) 


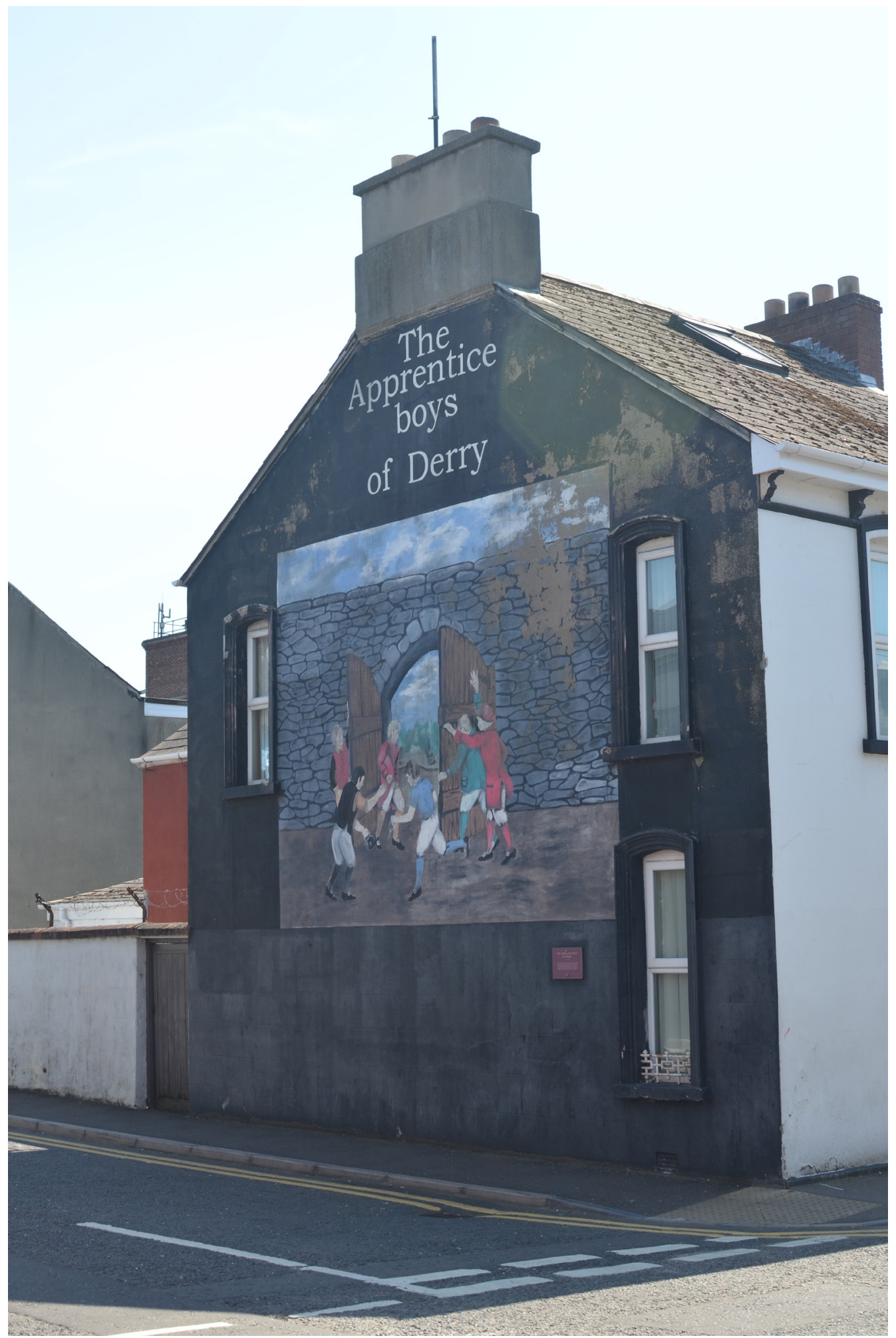

Figure 2.23. Loyalist mural in the Waterside commemorating the role of the Apprentice Boys in the Protestant victory during the Siege of Derry in 1689, August 2016 (Photograph taken by author) 


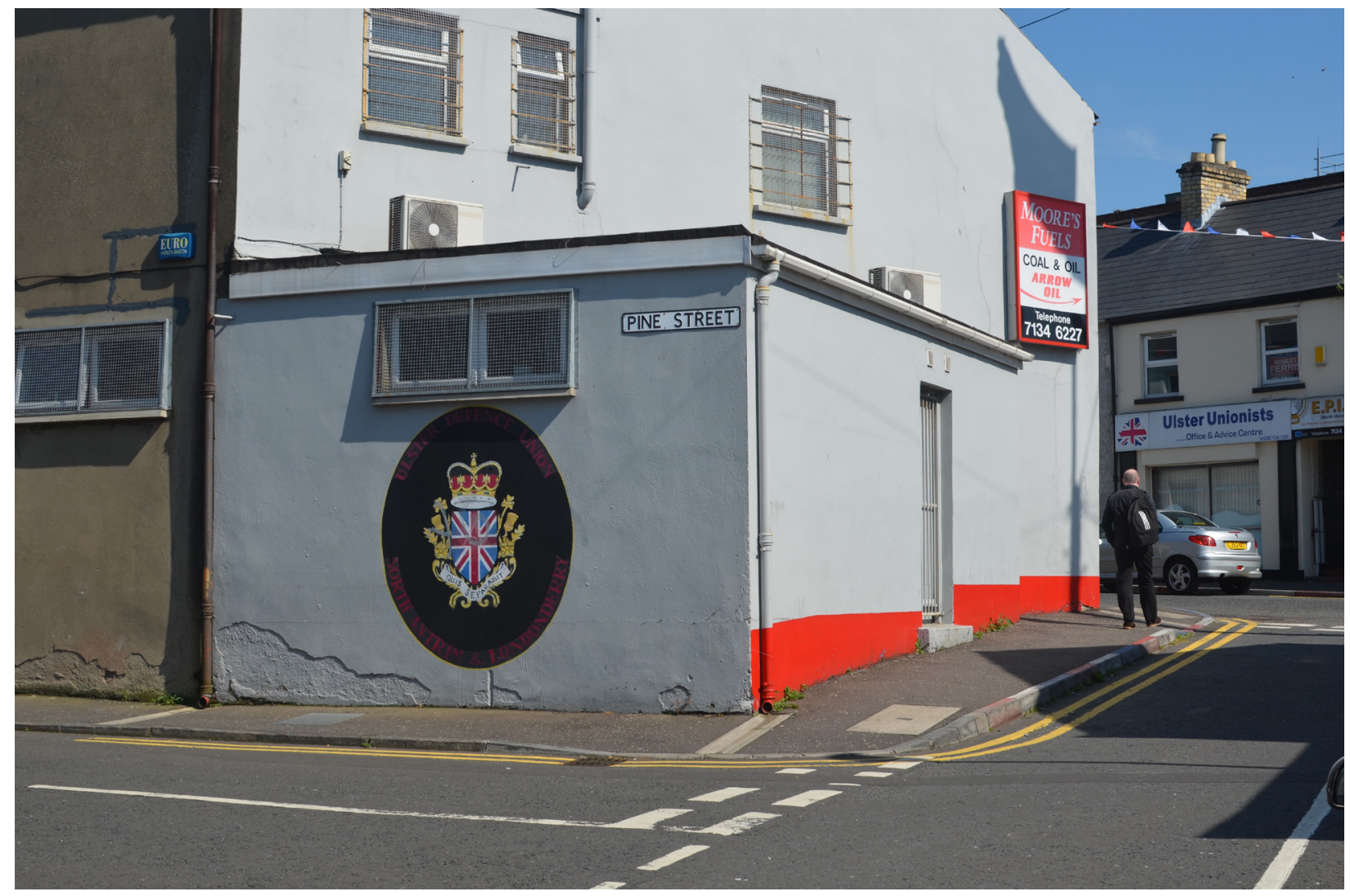

Figure 2.24. Loyalist mural in the Waterside depicting the crest of the Ulster Defence Union, August 2016 (Photograph taken by author) 


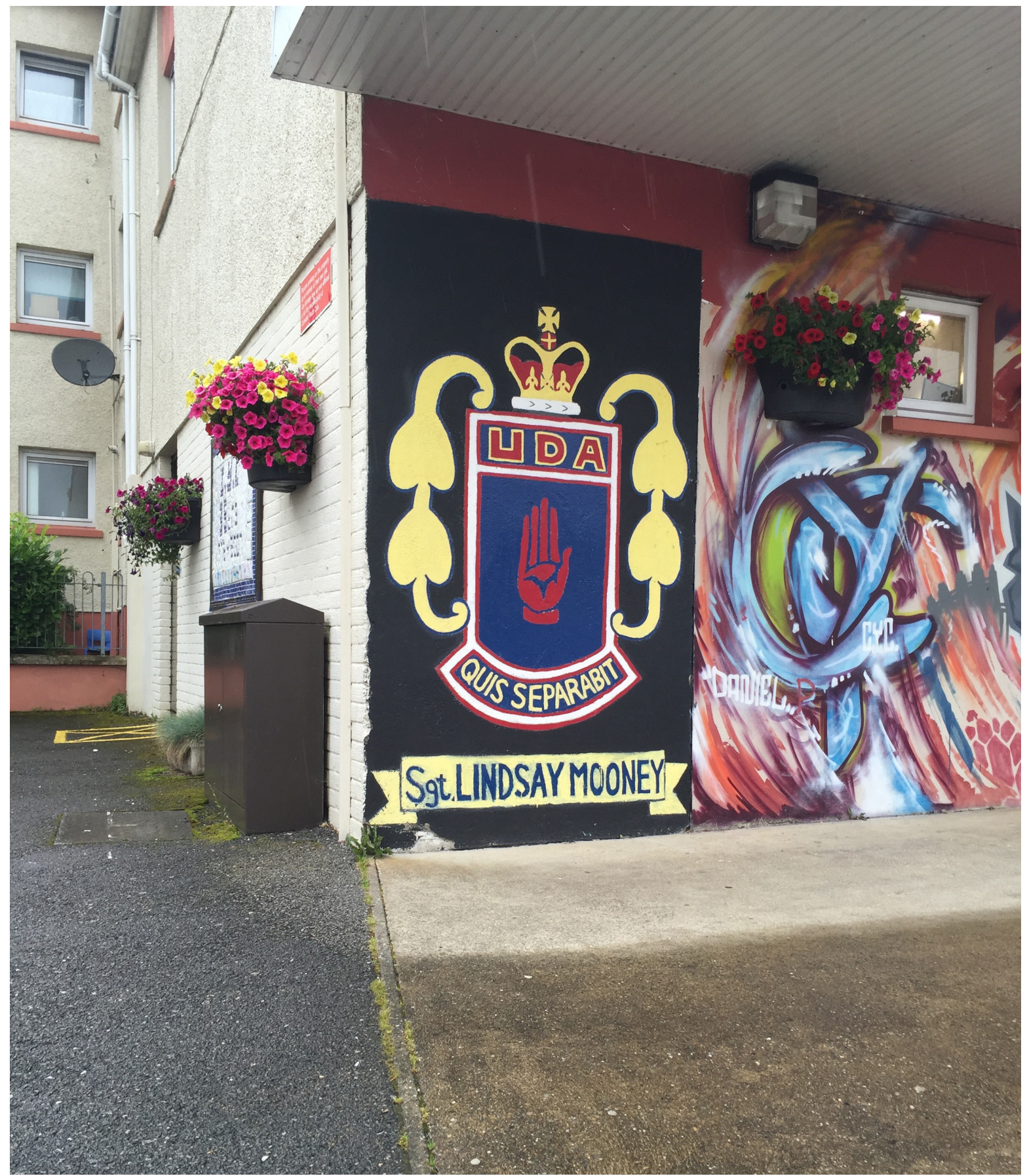

Figure 2.25. Loyalist commemorative mural in the Fountain depicting the crest of the Ulster Defence Association, August 2016 (Photograph taken by author) 


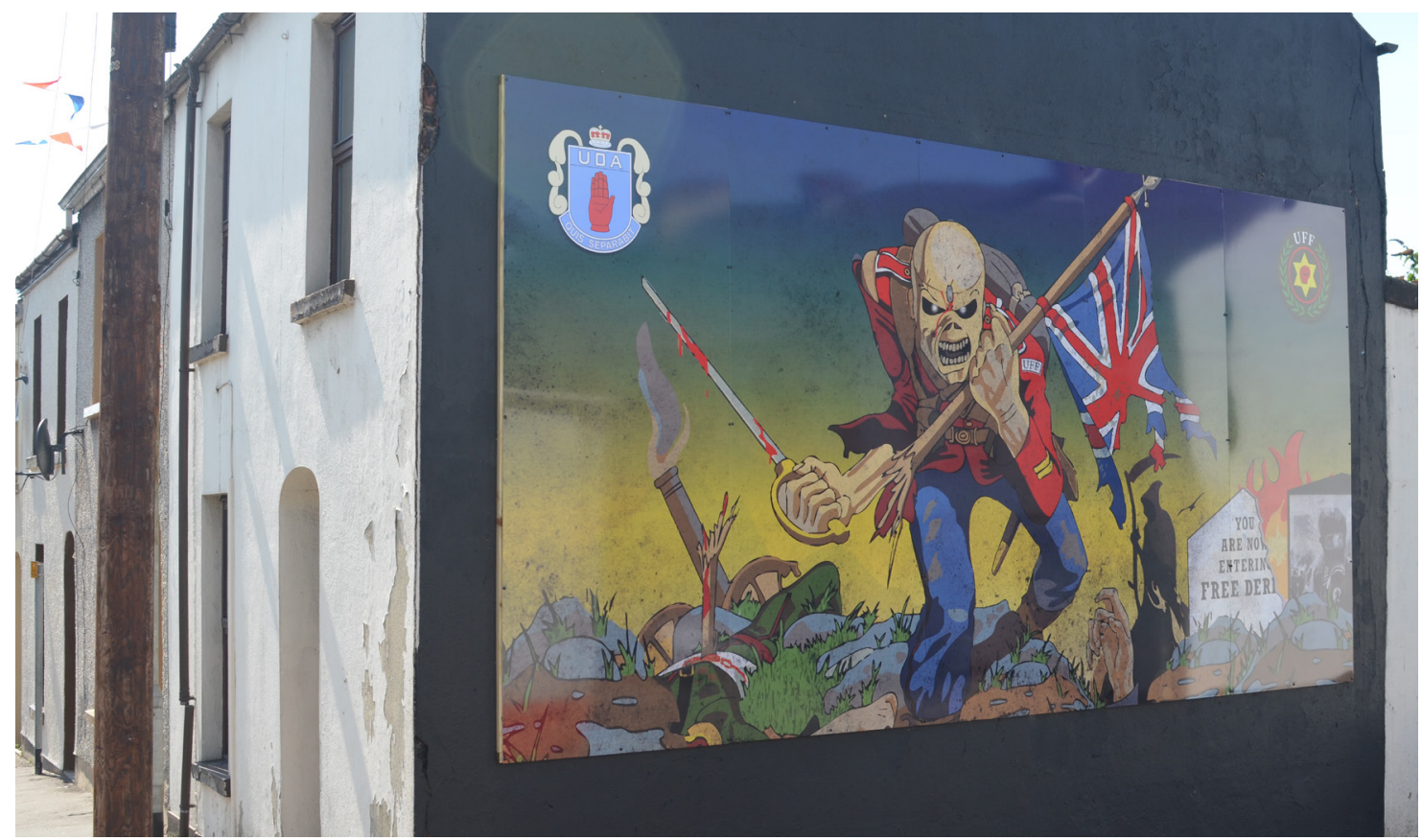

Figure 2.26. Loyalist mural in the Waterside depicting violent paramilitary imagery directed toward the Bogside, along with the crests of the Ulster Defence Association and Ulster Freedom Fighters, August 2016 (Photograph taken by author)

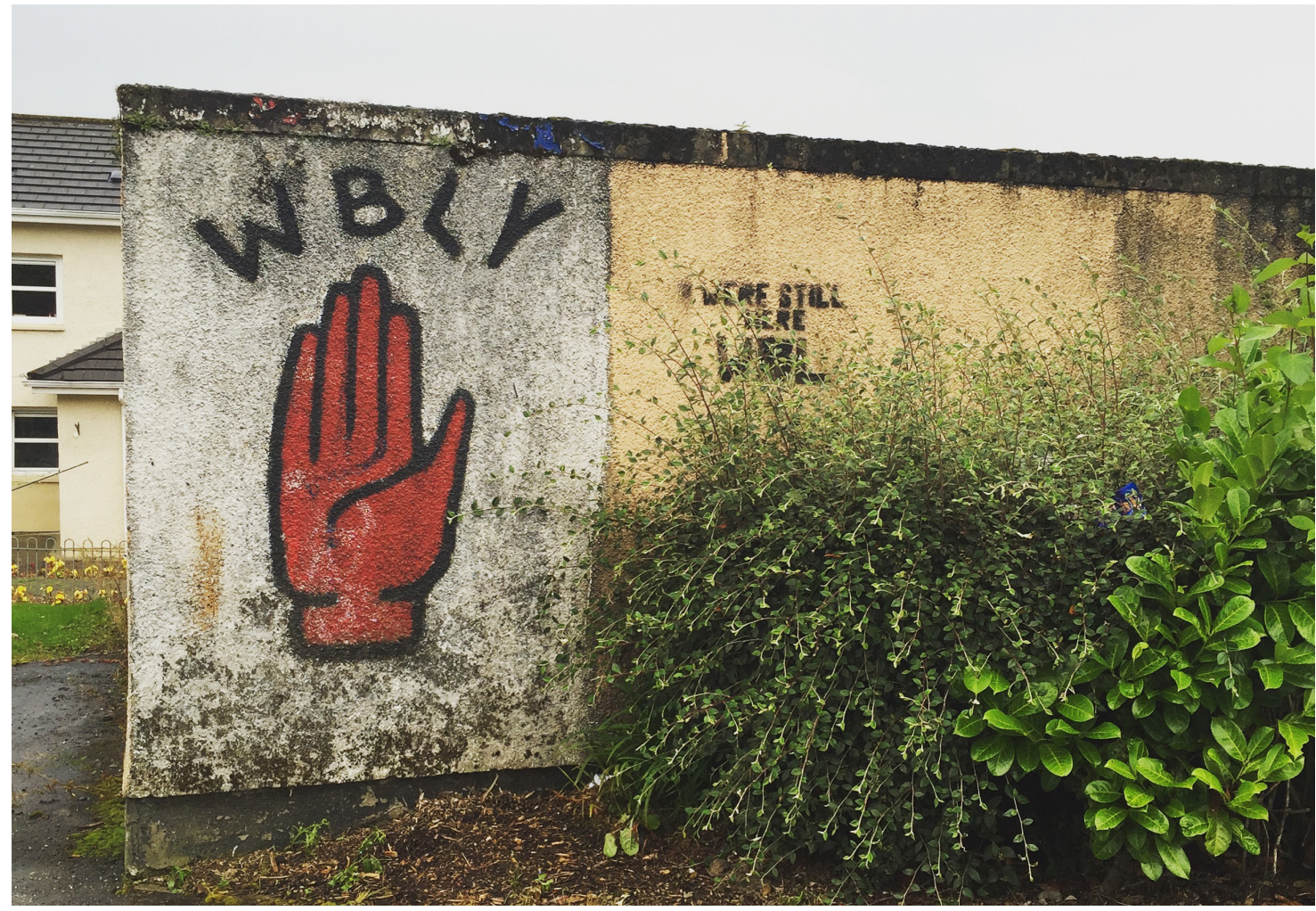

Figure 2.27. Loyalist mural in the Fountain depicting the Red Hand of Ulster, along with acronym reference to West Bank Loyalist Youth; August 2016 (Photograph taken by author) 


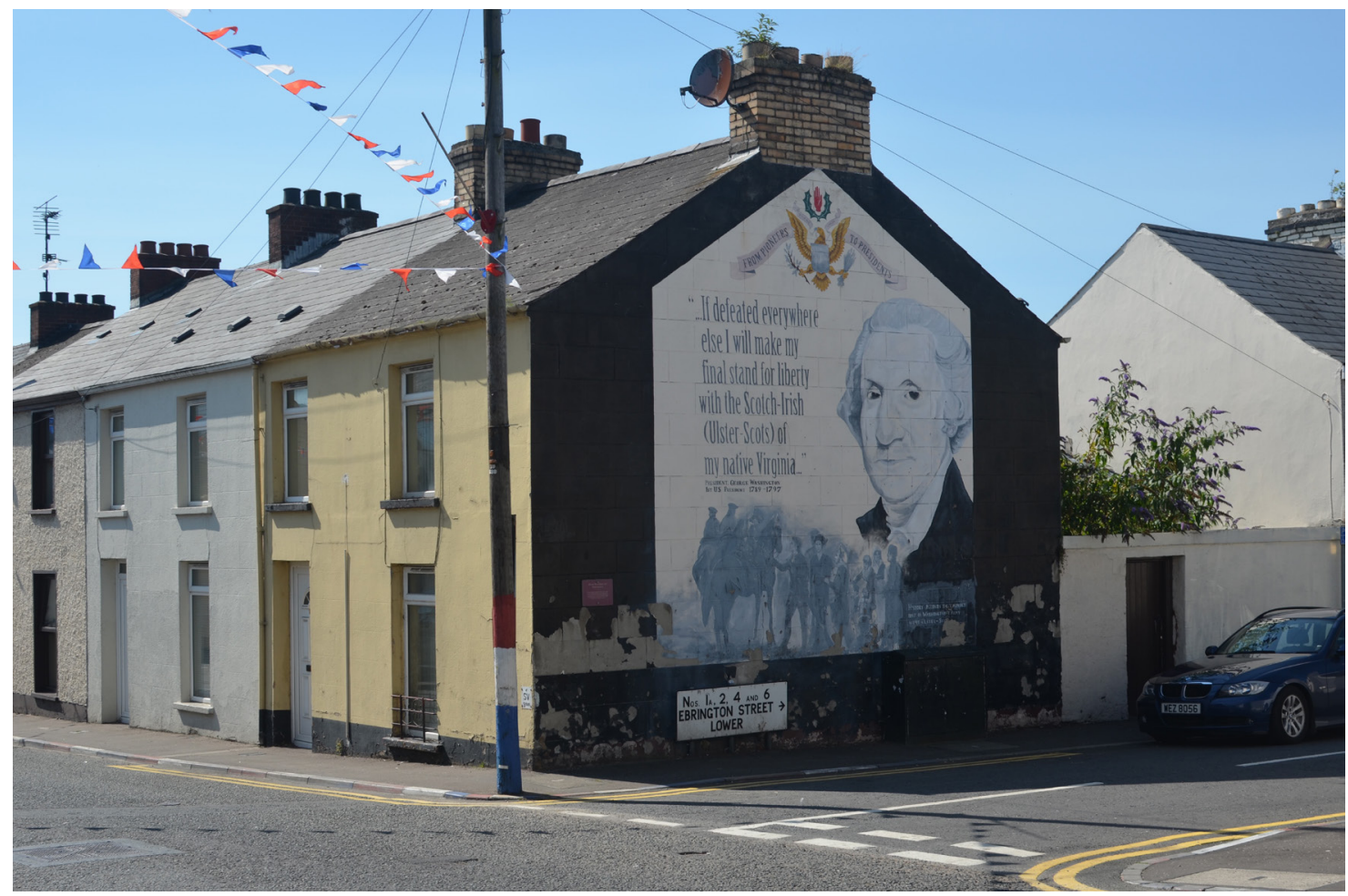

Figure 2.28. Loyalist mural in the Waterside depicting George Washington, along with reference to his willingness to defend his Ulster-Scot heritage in Virginia; August 2016 (Photograph taken by author)

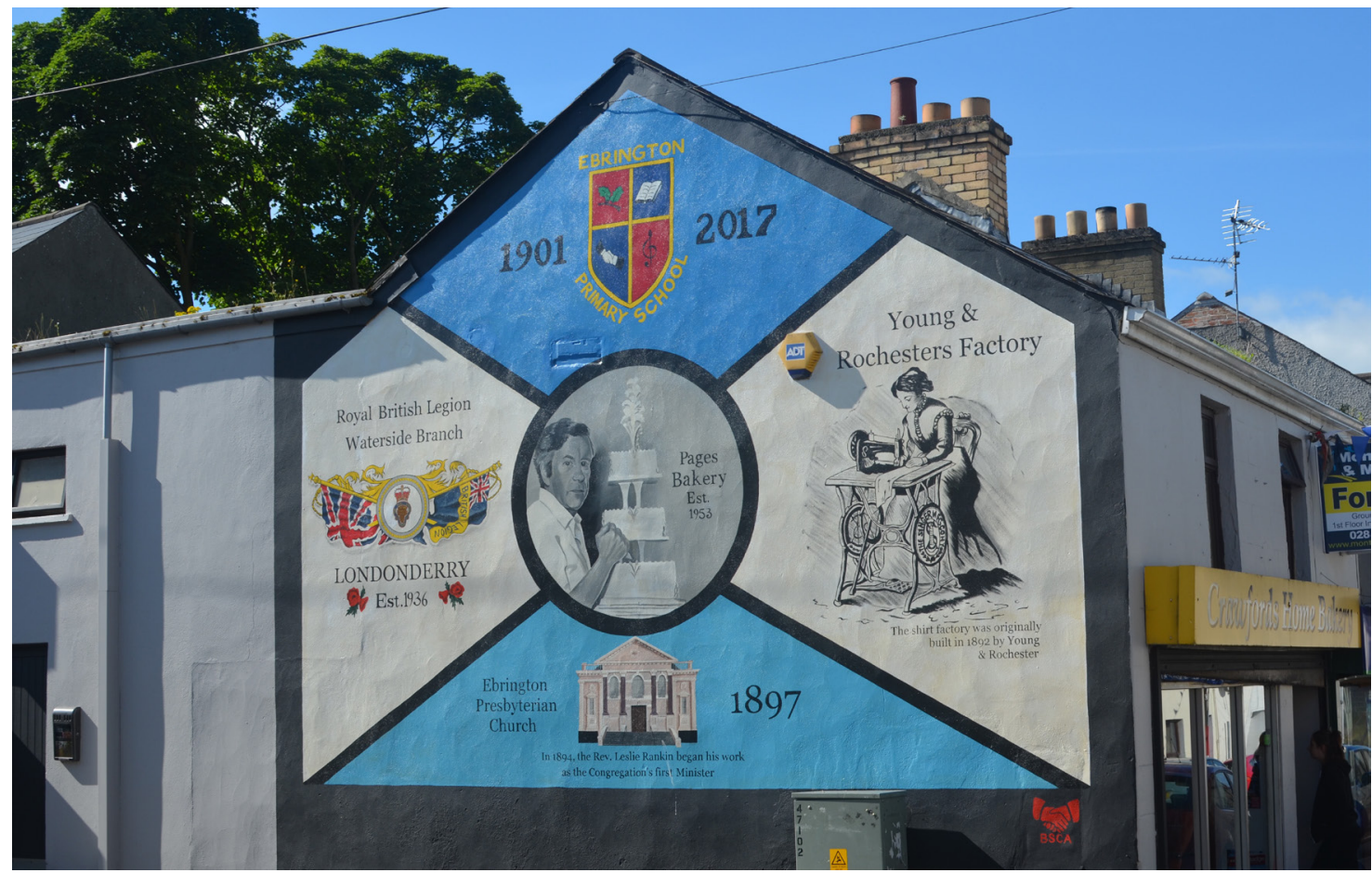

Figure 2.29. Loyalist mural in the Waterside commemorating historic community organizations; August 2016 (Photograph taken by author) 


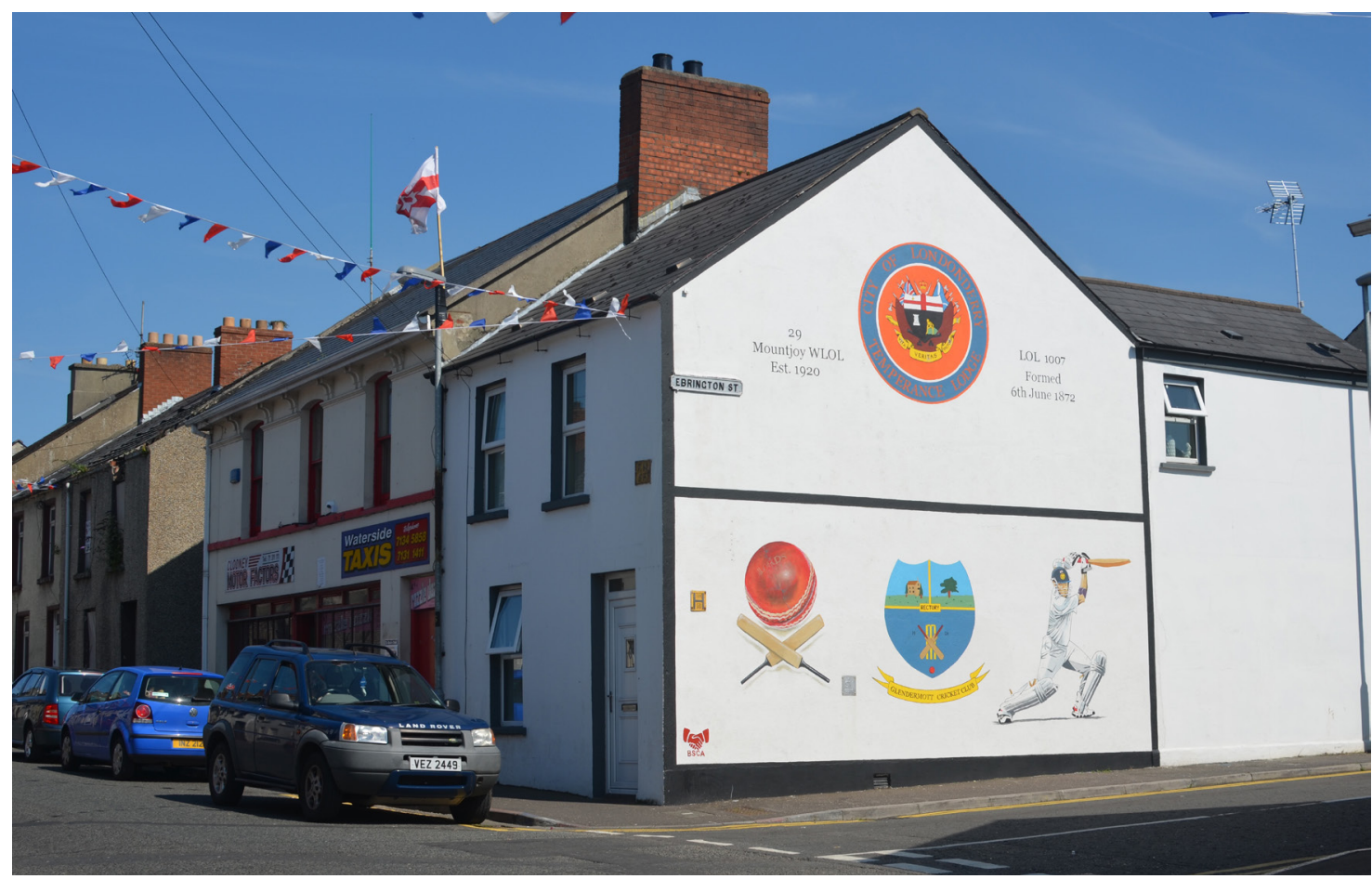

Figure 2.30. Loyalist mural in the Waterside commemorating the City of Londonderry Temperance Lodge and Glendermott Cricket Club; August 2016 (Photograph taken by author)

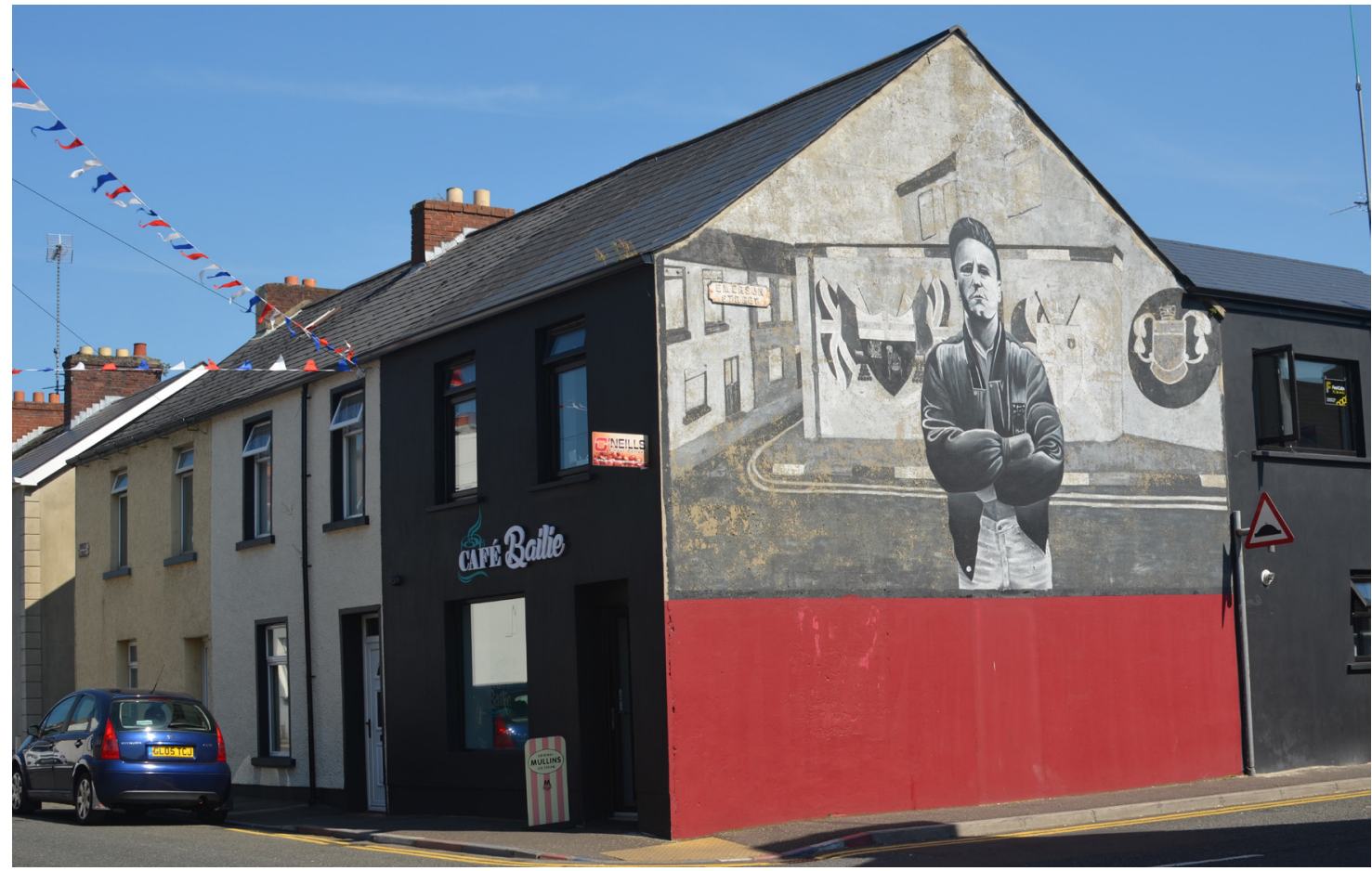

Figure 2.31. Loyalist mural in the Waterside commemorating a local victim of paramilitary violence during the Troubles; August 2016 (Photograph taken by author) 


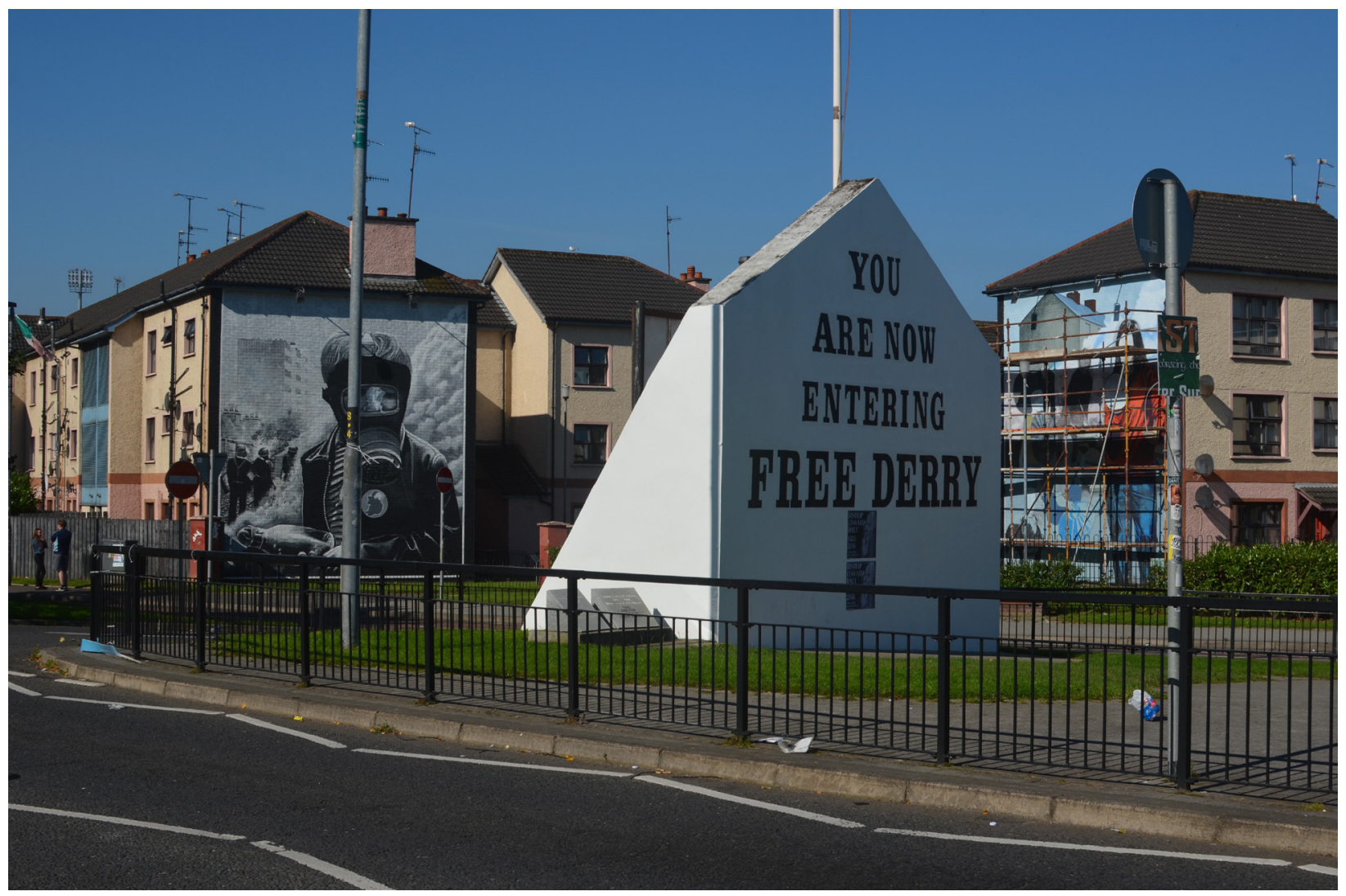

Figure 2.32. "The Petrol Bomber" and "Bernadette," People's Gallery murals commemorating events during the Battle of the Bogside, alongside Free Derry Corner; August 2016 (Photograph taken by author)
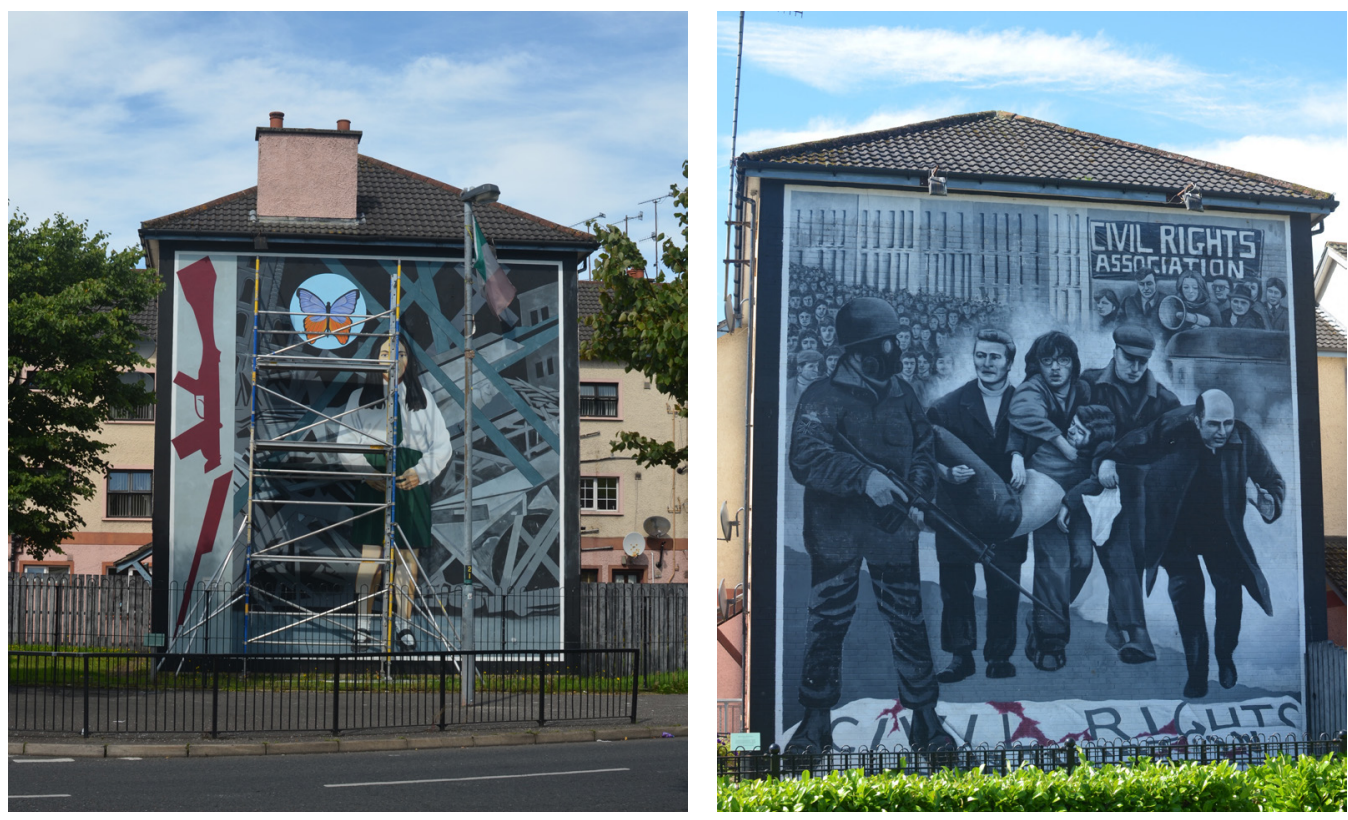

Figure 2.33. "Death of Innocence" and "Bloody Sunday," People's Gallery murals commemorating the 1971 death of Annette McGavigan and Bloody Sunday (1972); August 2016 (Photograph taken by author) 

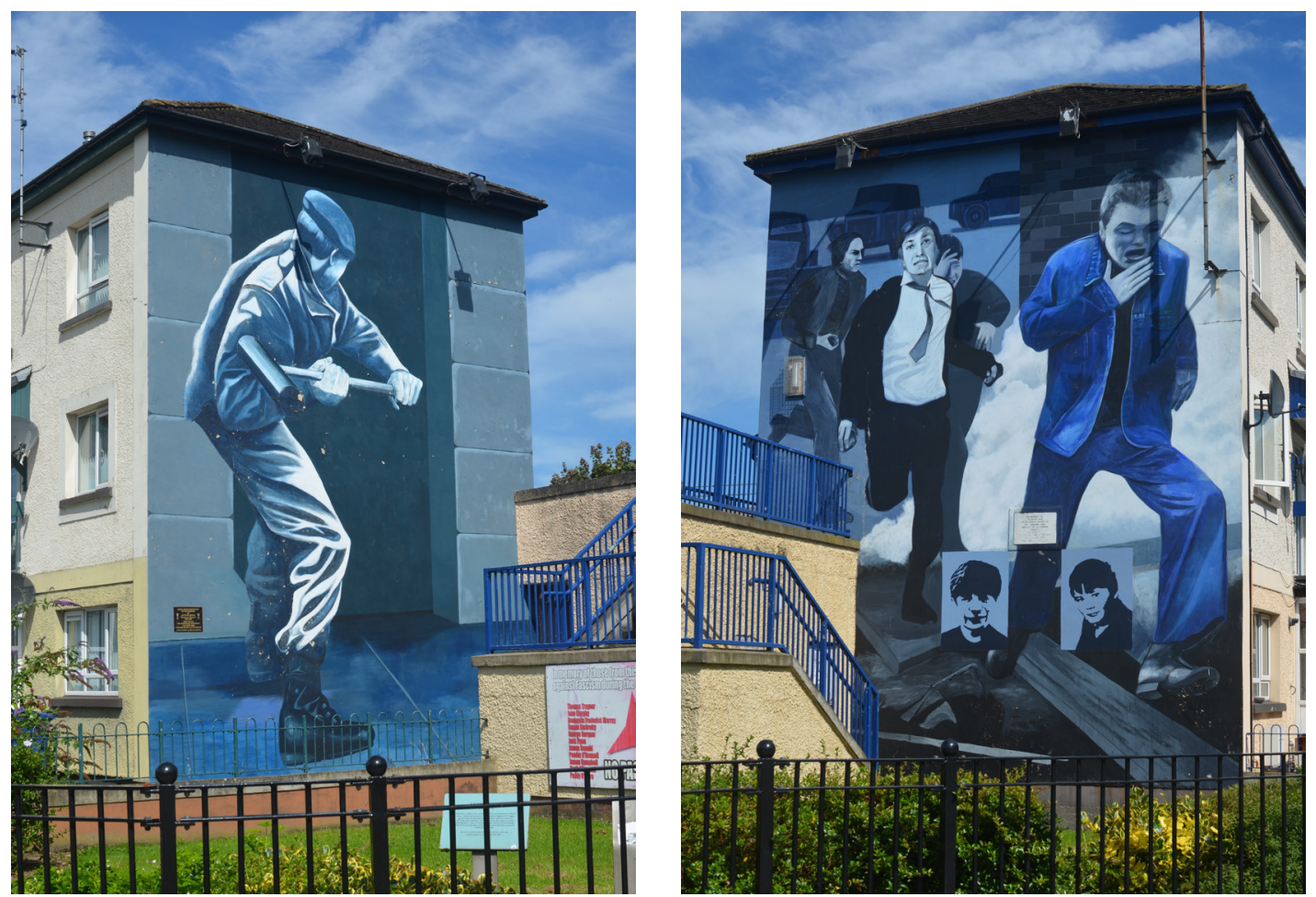

Figure 2.34. "Motorman" and "The Runner," People's Gallery murals depicting Operation Motorman (1972) and the use of CS gas during Bogside riots; August 2016 (Photograph taken by author)
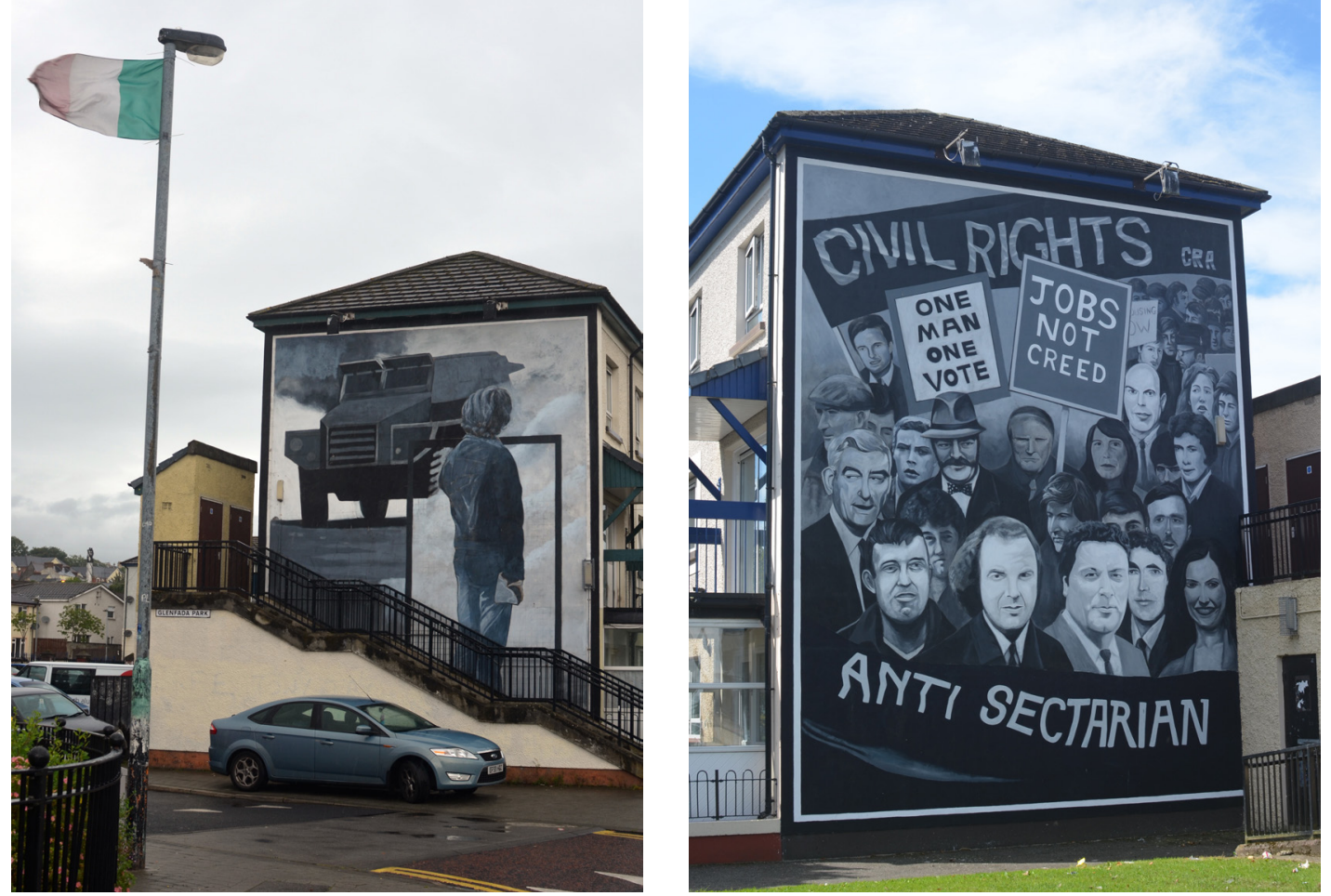

Figure 2.35. "The Rioter" and "Civil Rights," People's Gallery murals depicting rioting during the Troubles and commemorating key individuals of the Northern Irish civil rights movement during the 1960s; August 2016 (Photograph taken by author) 

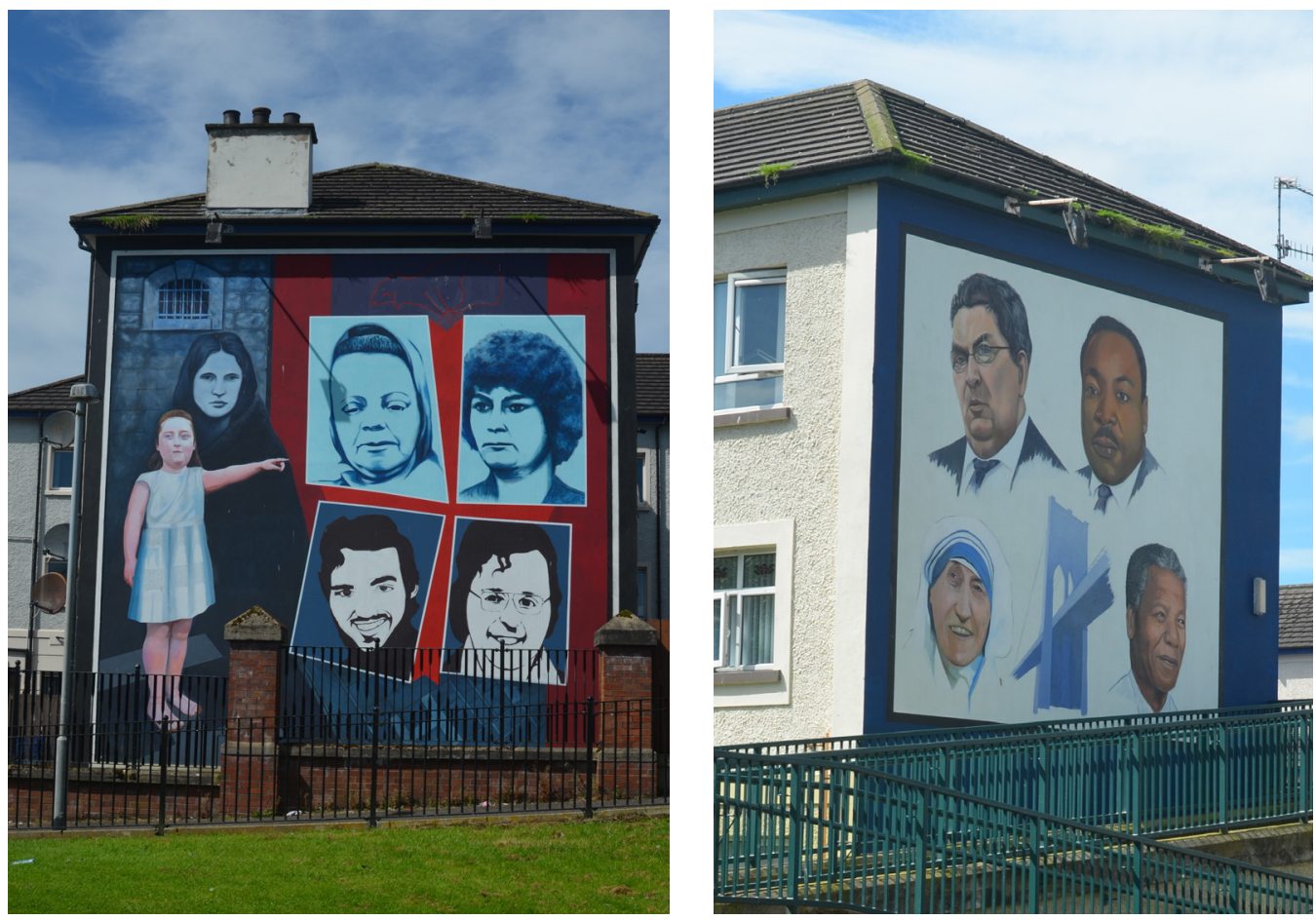

Figure 2.36. "Hunger Strike" and "Tribute to John Hume," People's Gallery murals commemorating hunger strikers and depicting civil rights leader John Hume alongside fellow Nobel Peace Prize Winners Martin Luther King Jr, Mother Teresa, and Nelson Mandela; August 2016 (Photograph taken by author)

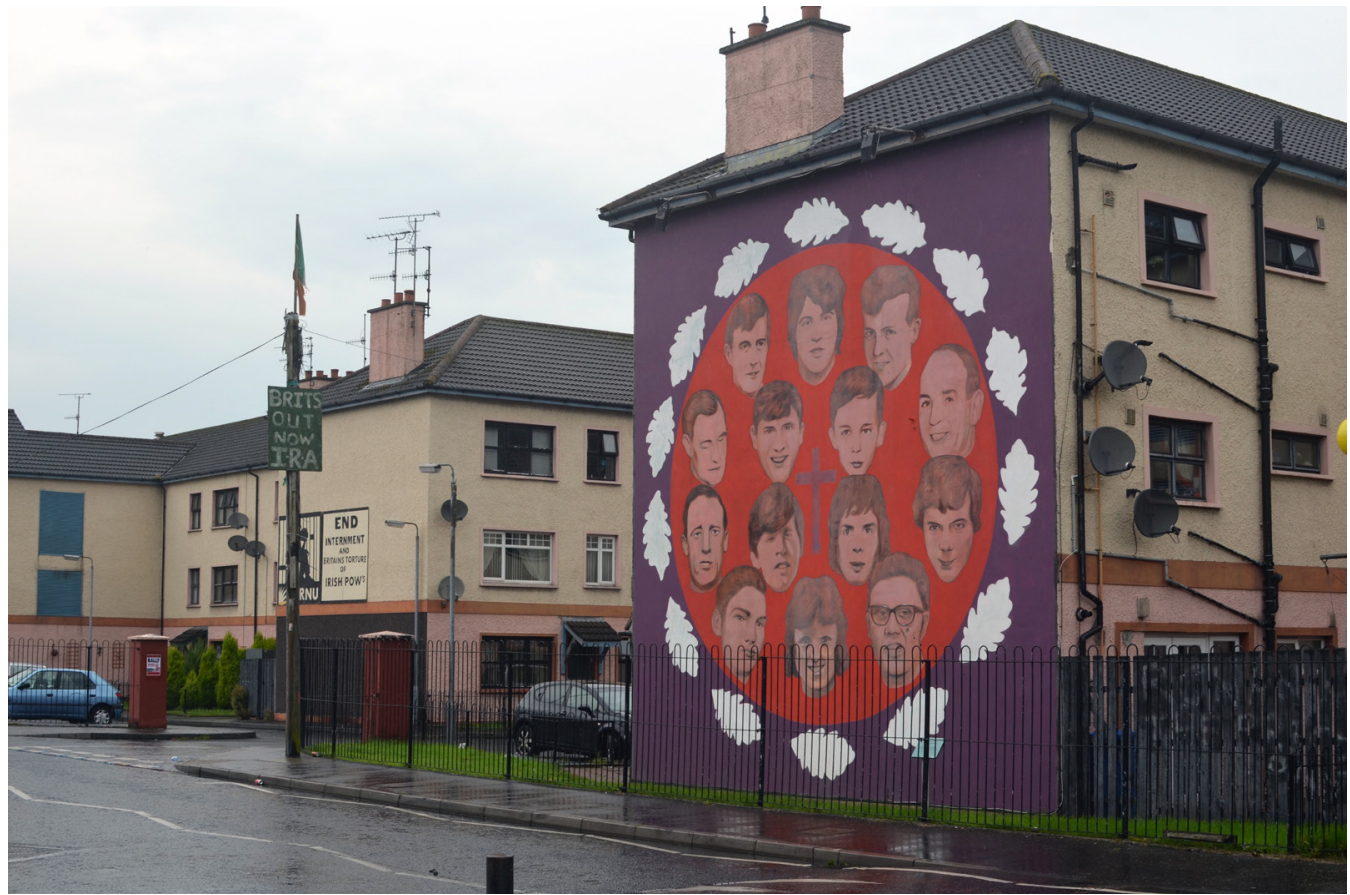

Figure 2.37. "The Bloody Sunday Commemoration," People's Gallery mural memorializing Bogside residents killed on Bloody Sunday; August 2016 (Photograph taken by author) 


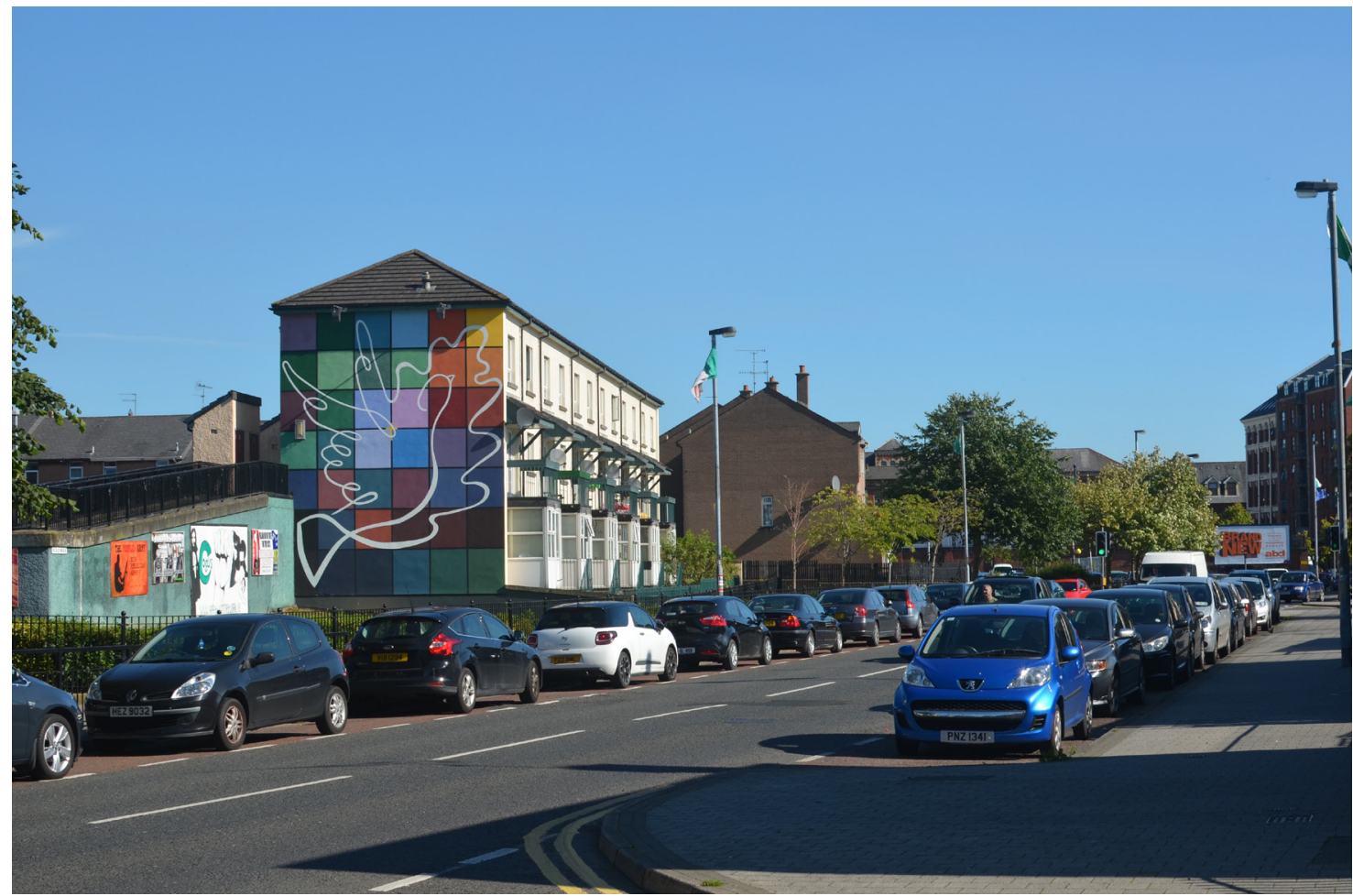

Figure 2.38. "The Peace Mural," culmination of the People's Gallery, within the urban context of the Bogside; August 2016 (Photograph taken by author)

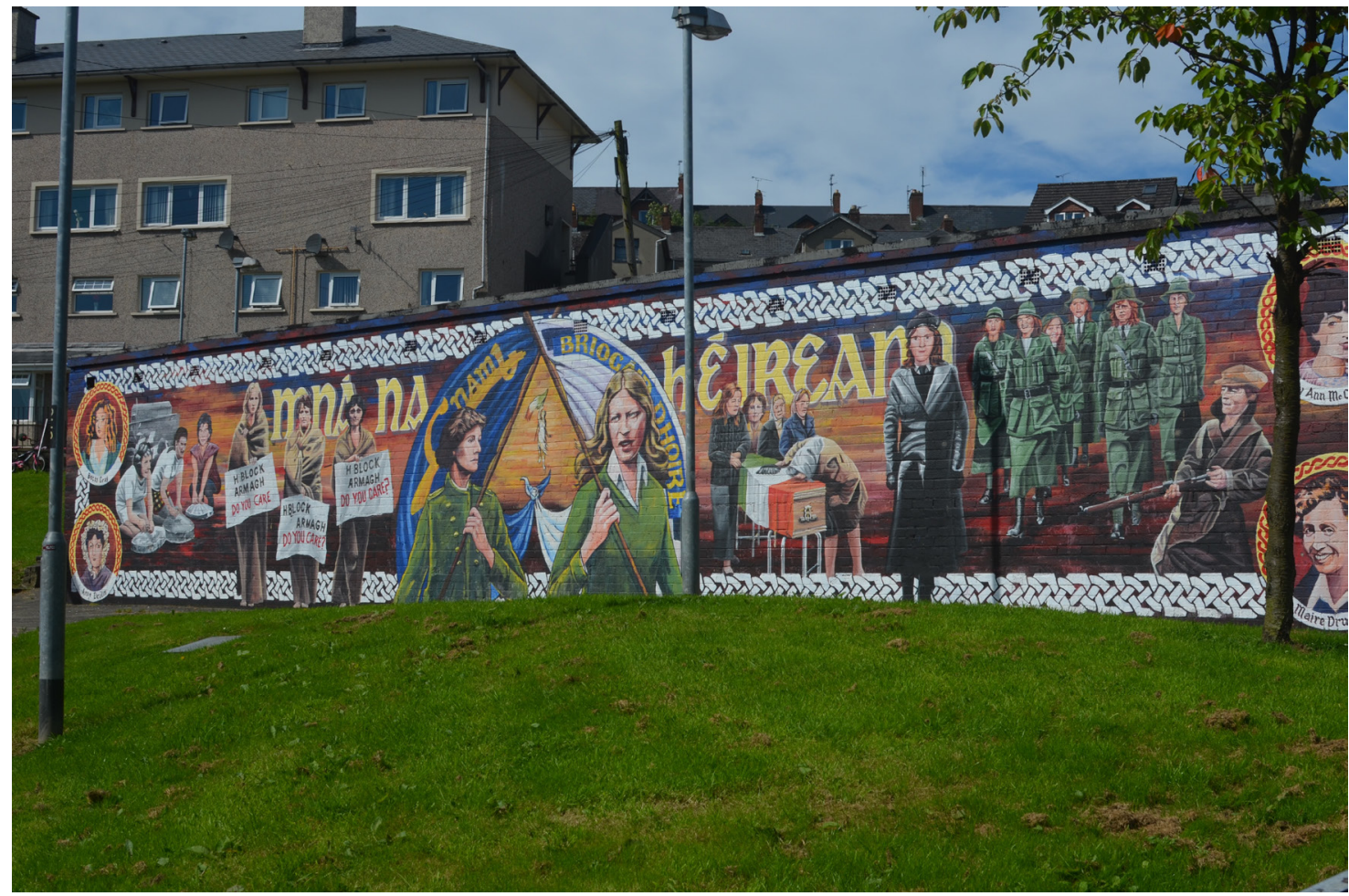

Figure 2.39. "Women of Ireland" mural commemorating the historical contributions by women to the Republican struggle, Gartan Square, Bogside; August 2016 (Photograph taken by author) 


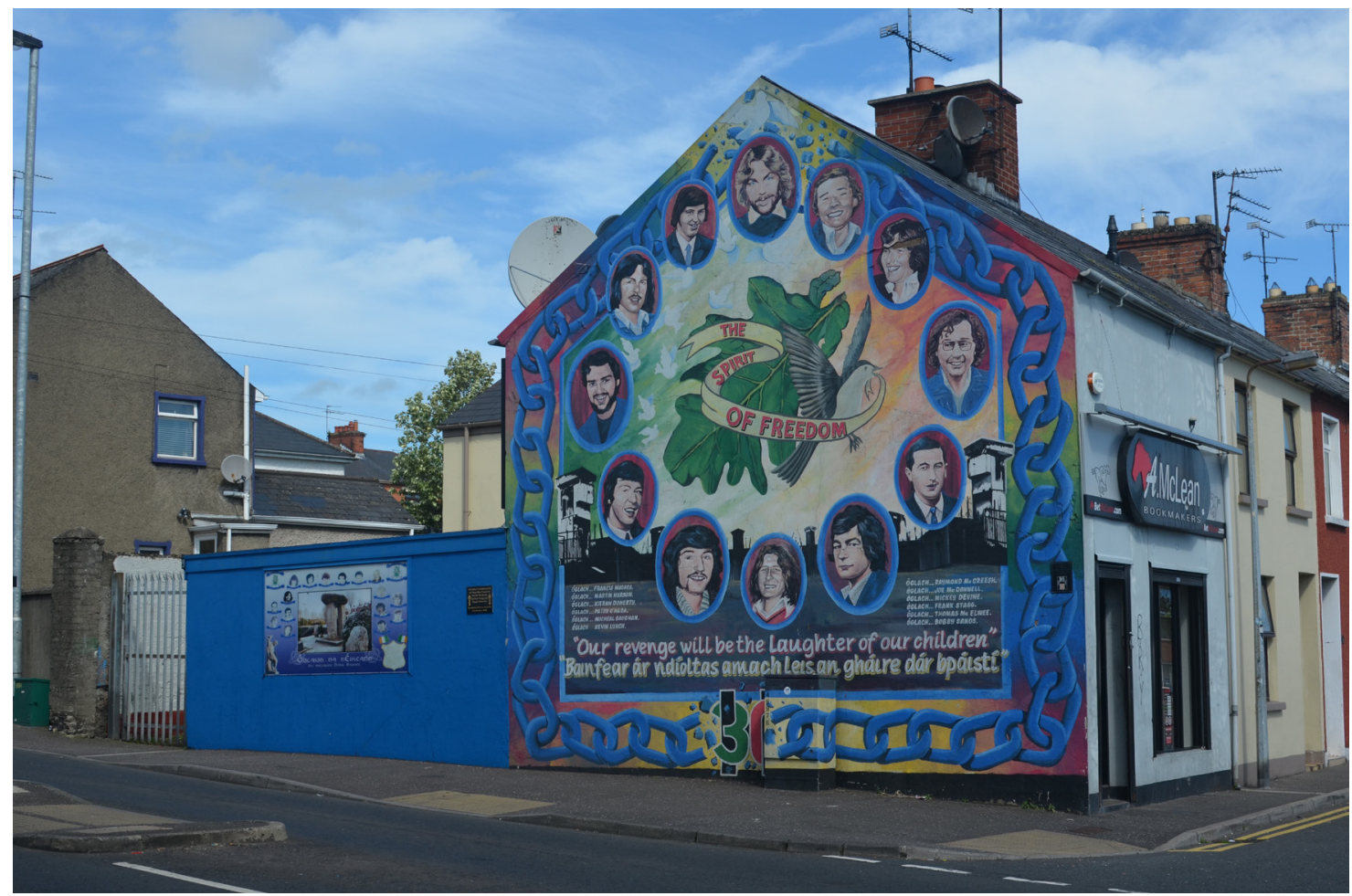

Figure 2.40. "Spirit of Freedom" mural commemorating the 30th anniversary of the 1981 hunger strikes, Westland St., Bogside; August 2016 (Photograph taken by author)

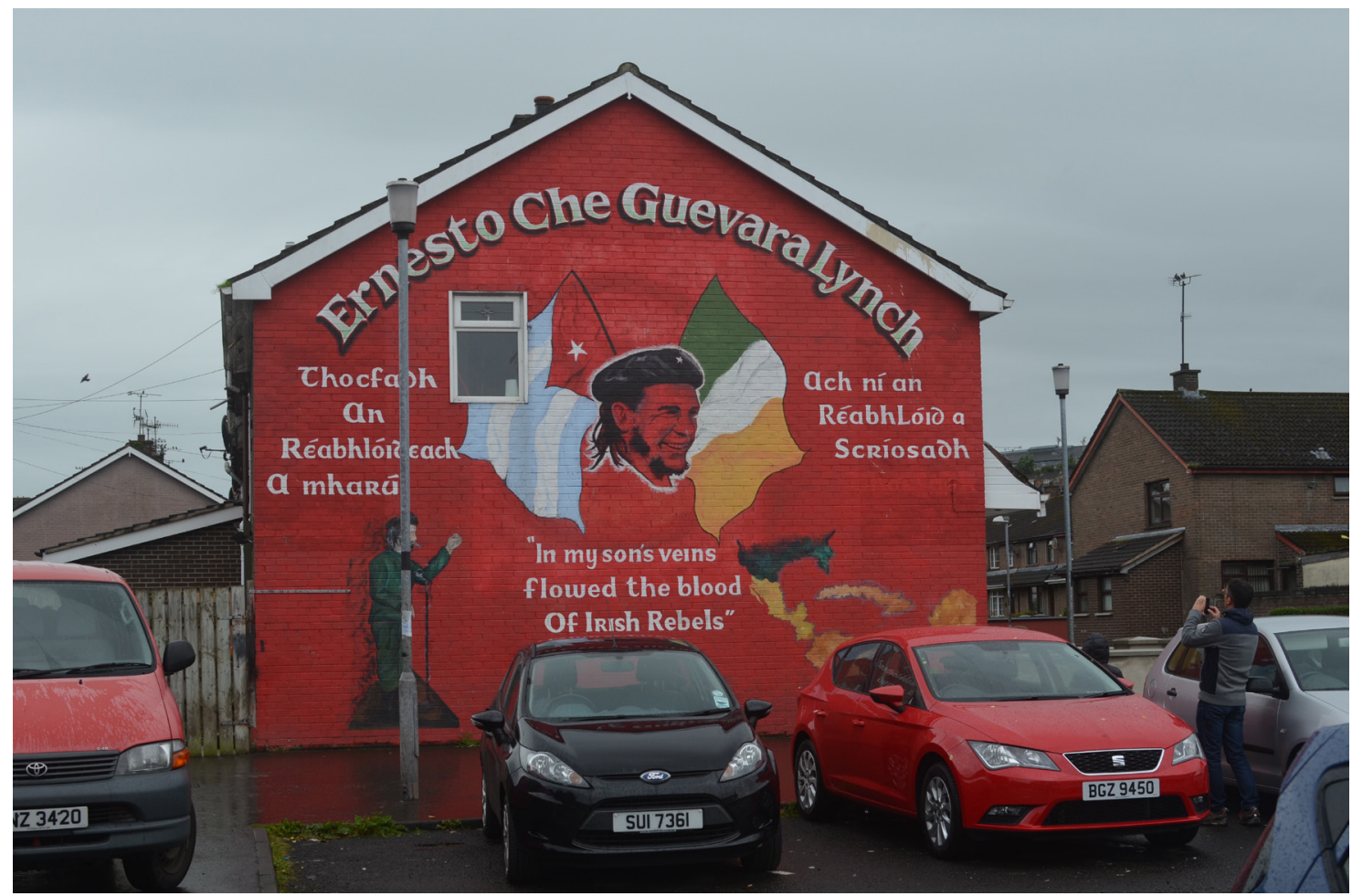

Figure 2.41. Bogside mural commemorating the 40th anniversary of the death of Che Guevara; August 2016 (Photograph taken by author) 


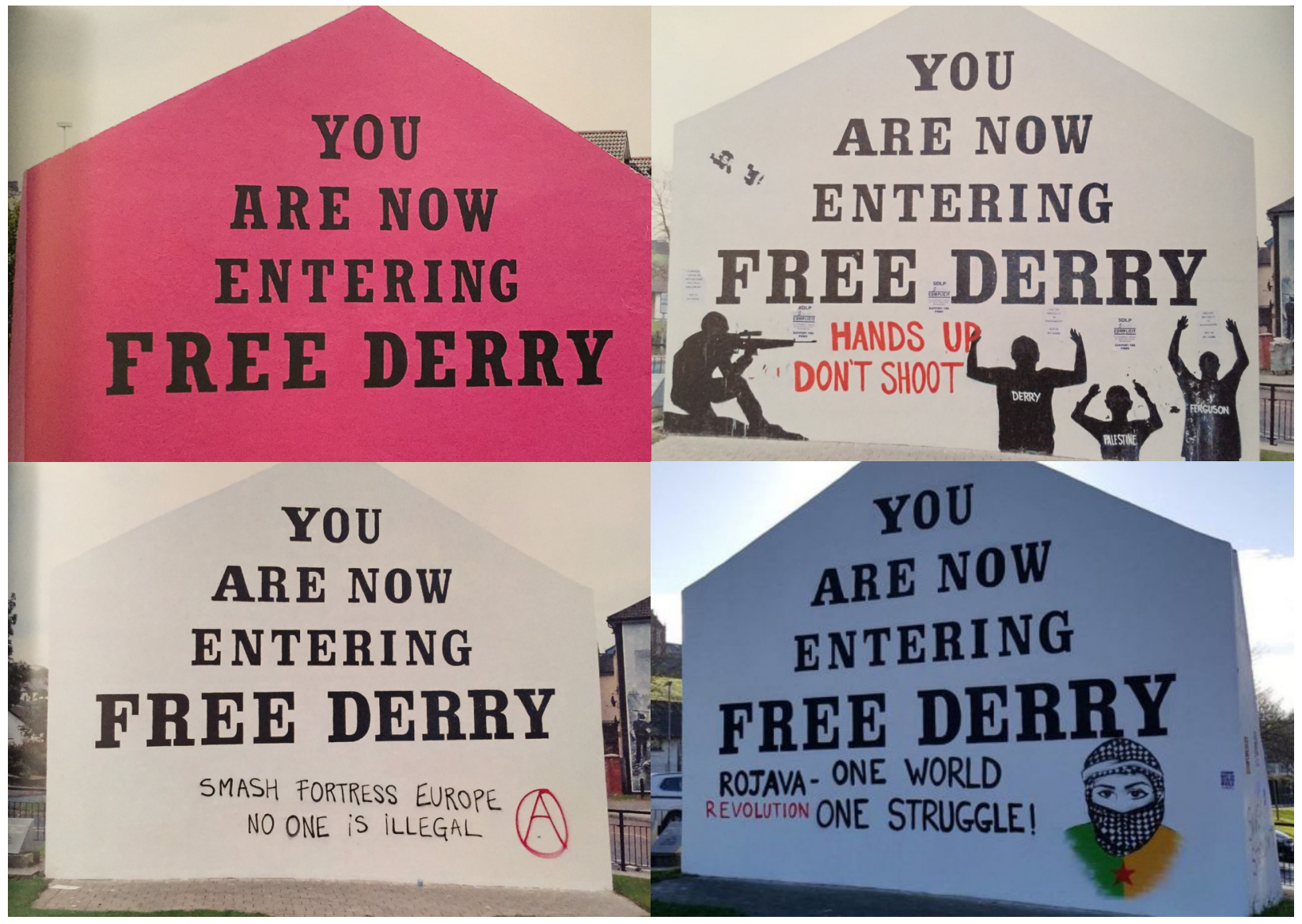

Figure 2.42. Free Derry Corner altered to show solidarity with international political movements. From top left: LGBT Pride (2007), Ferguson/Black Lives Matter (2014), Syrian migrant crisis and far-right backlash (2015), Rojava Revolution (Jan. 2017); (Sources: Murals of Derry, Derry Now) 


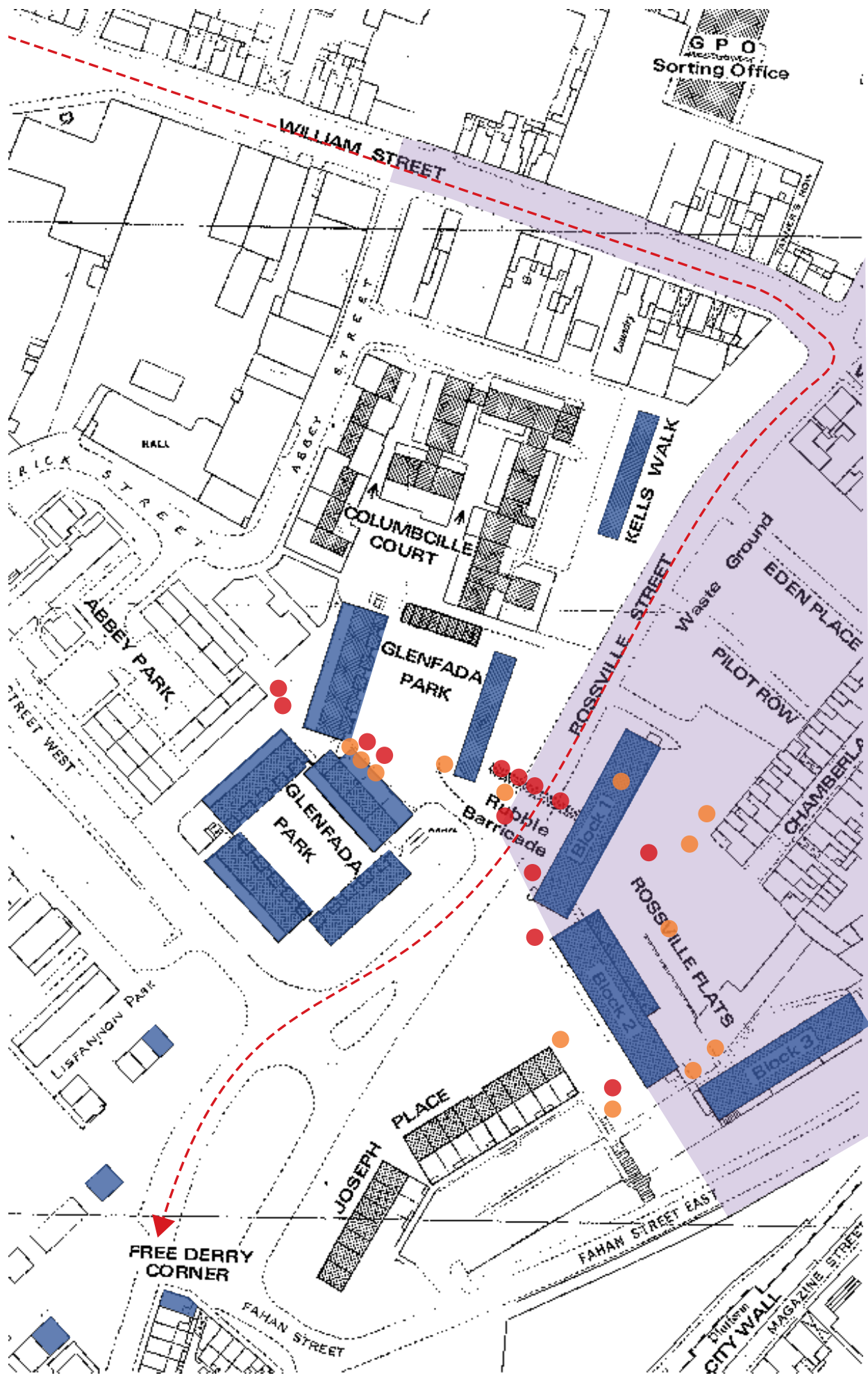

Battle of the Bogside (1969)

Main Area of Conflict

Bloody Sunday (1972)

Killed

Wounded

- . - - Planned March Route

Political Murals (1980s-90s)

Sites of Prominent

Republican Murals

Figure 2.43. Composite map showing spatial relationships between the Battle of the Bogside (1969), Bloody Sunday (1972), and sites of prominent Republican political murals in the Bogside (Base Map from Widgery Tribunal report, mapping by author based on information from Stetler, The Battle of Bogside; Principal Conclusions and Overall Assessment of the Bloody Sunday Inquiry; and collected mural photographs and research) 

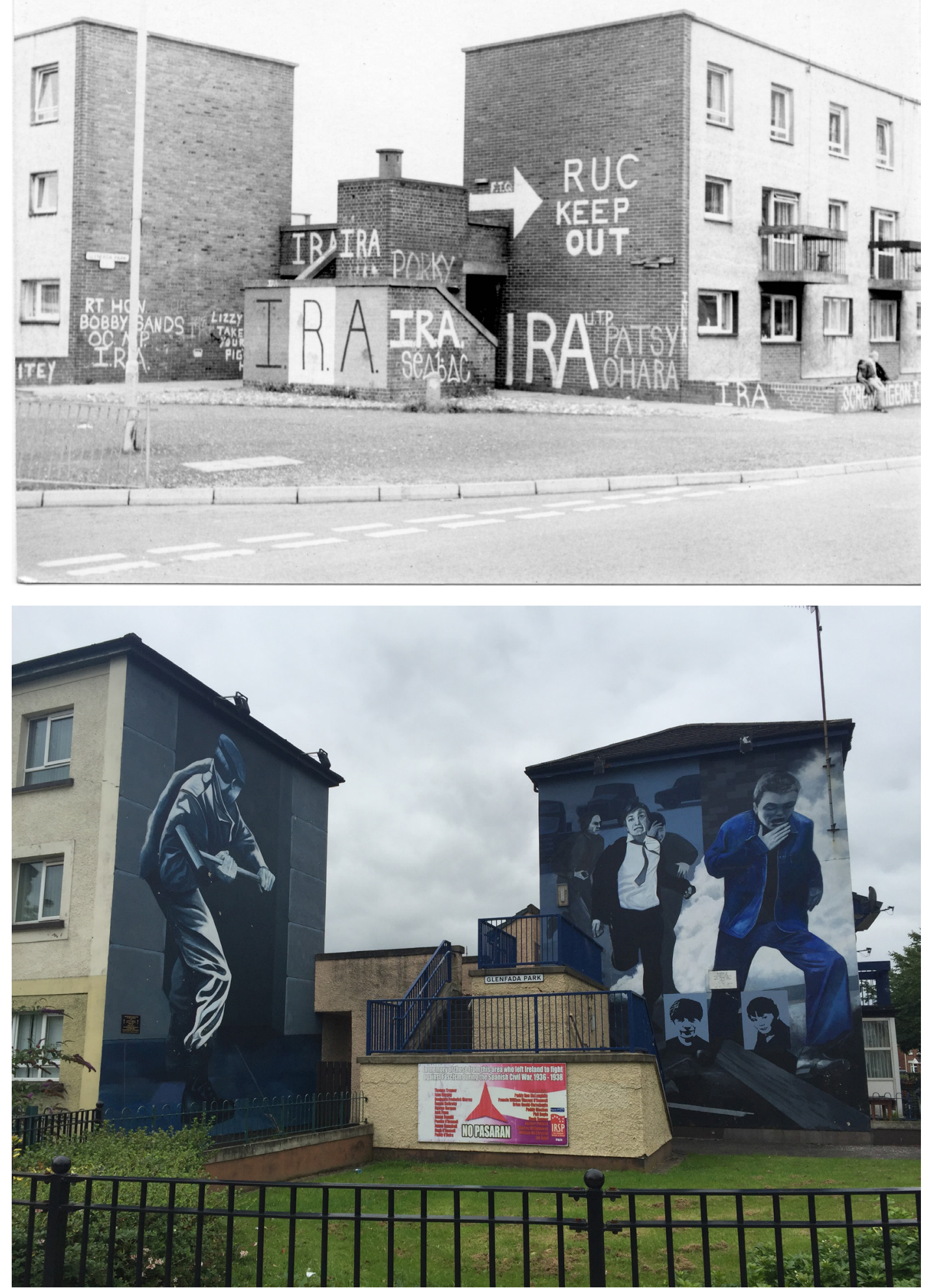

Figure 2.44. Comparison of early political artwork (1983) and current People's Gallery murals (August 2016) at Glenfada Park, facing Rossville Street (First image: Tony Crowley, Murals of Northern Ireland Collection, Claremont College Digital Library; Second image: Photo taken by author) 


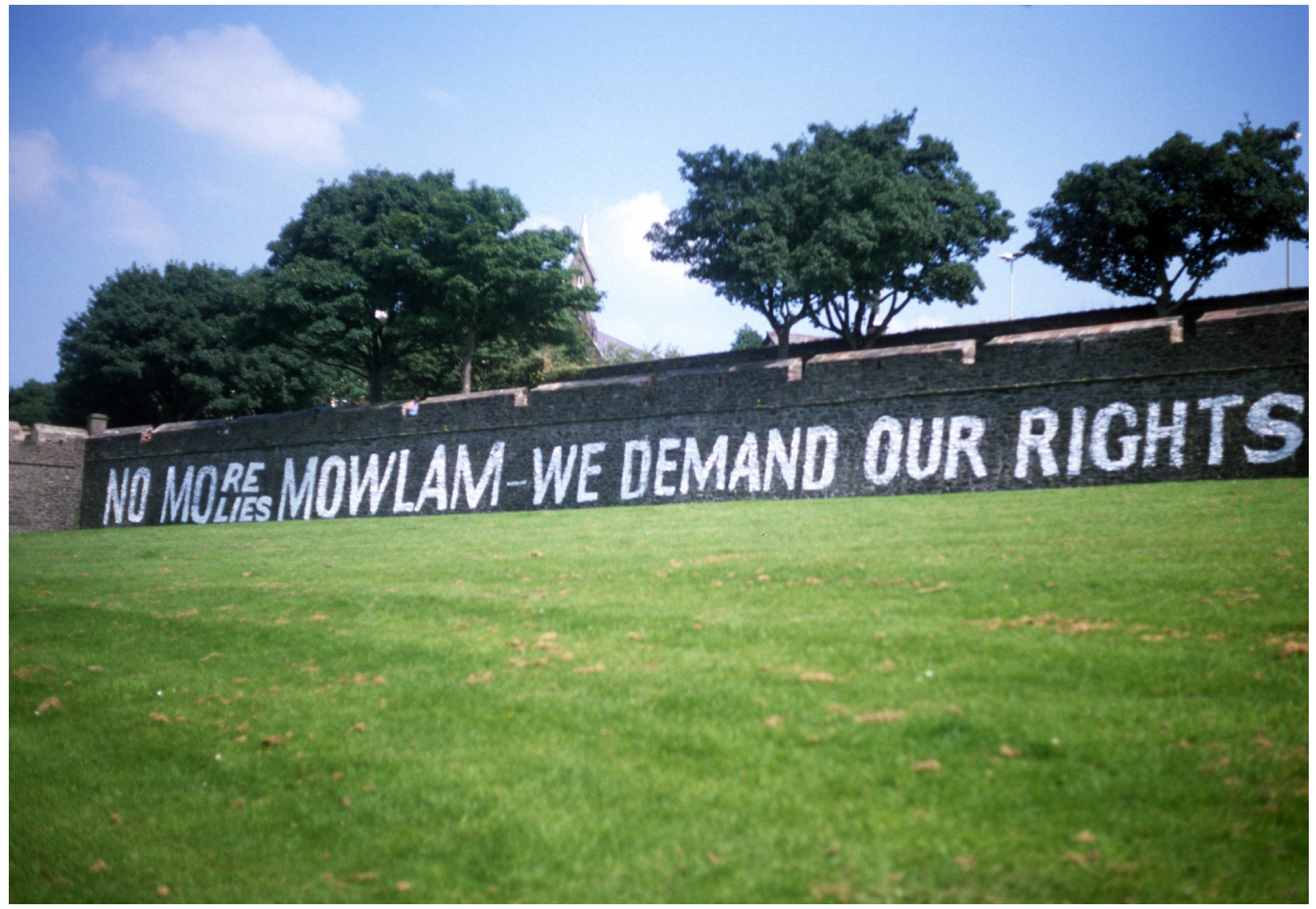

Figure 2.45. 1996 photograph showing Republican political graffiti painted on Derry's historic city walls (Source: Tony Crowley; Murals of Northern Ireland archive, Claremont Colleges Digital Library) 


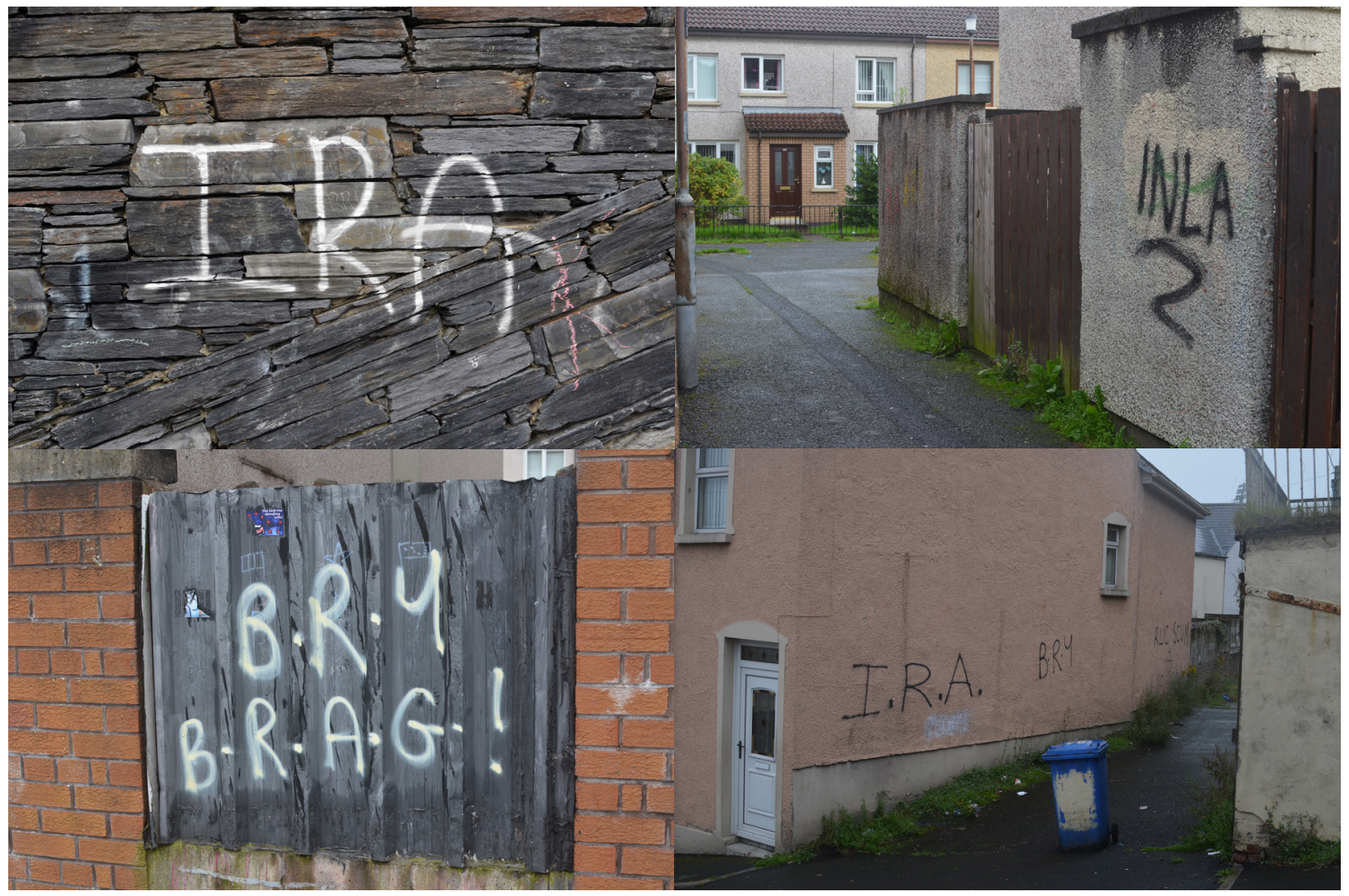

Figure 2.46. Photographs showing examples of paramilitary and other organizational graffiti within the Bogside; August 2016 (Photographs taken by author)

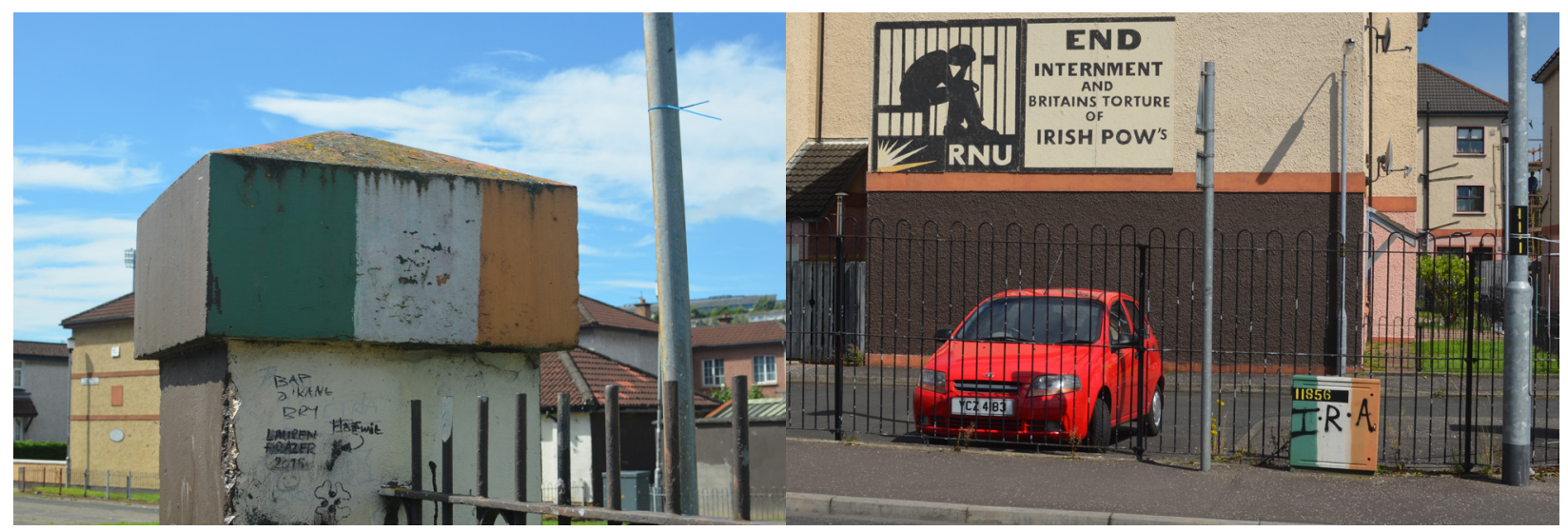

Figure 2.47. Photographs showing examples of everyday urban elements within the Bogside painted to resemble the Irish tricolour; August 2016 (Photographs taken by author) 

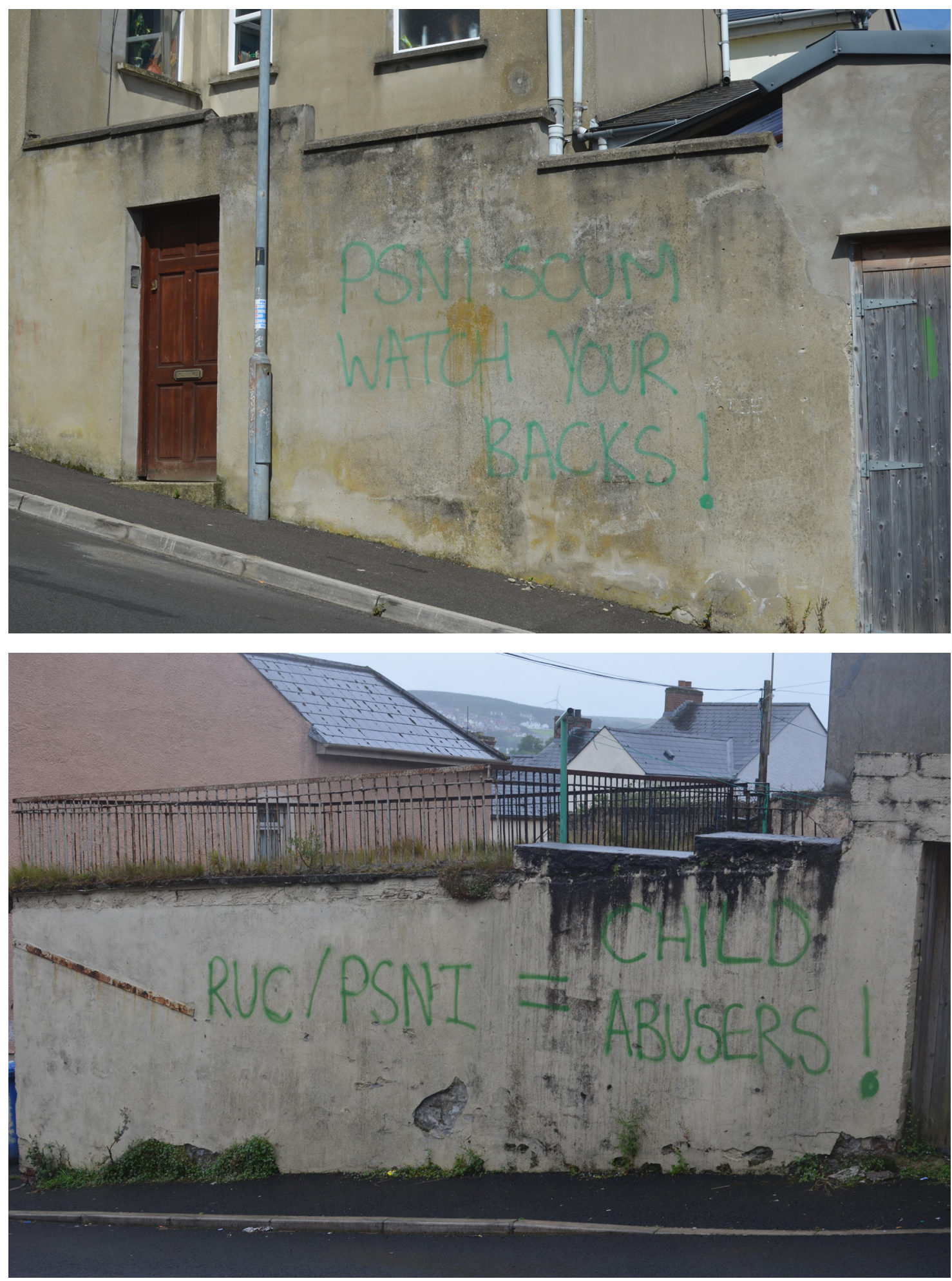

Figure 2.48. Photographs showing examples of graffiti within the Bogside expressing threats and animosity toward the local police force; August 2016 (Photographs taken by author) 


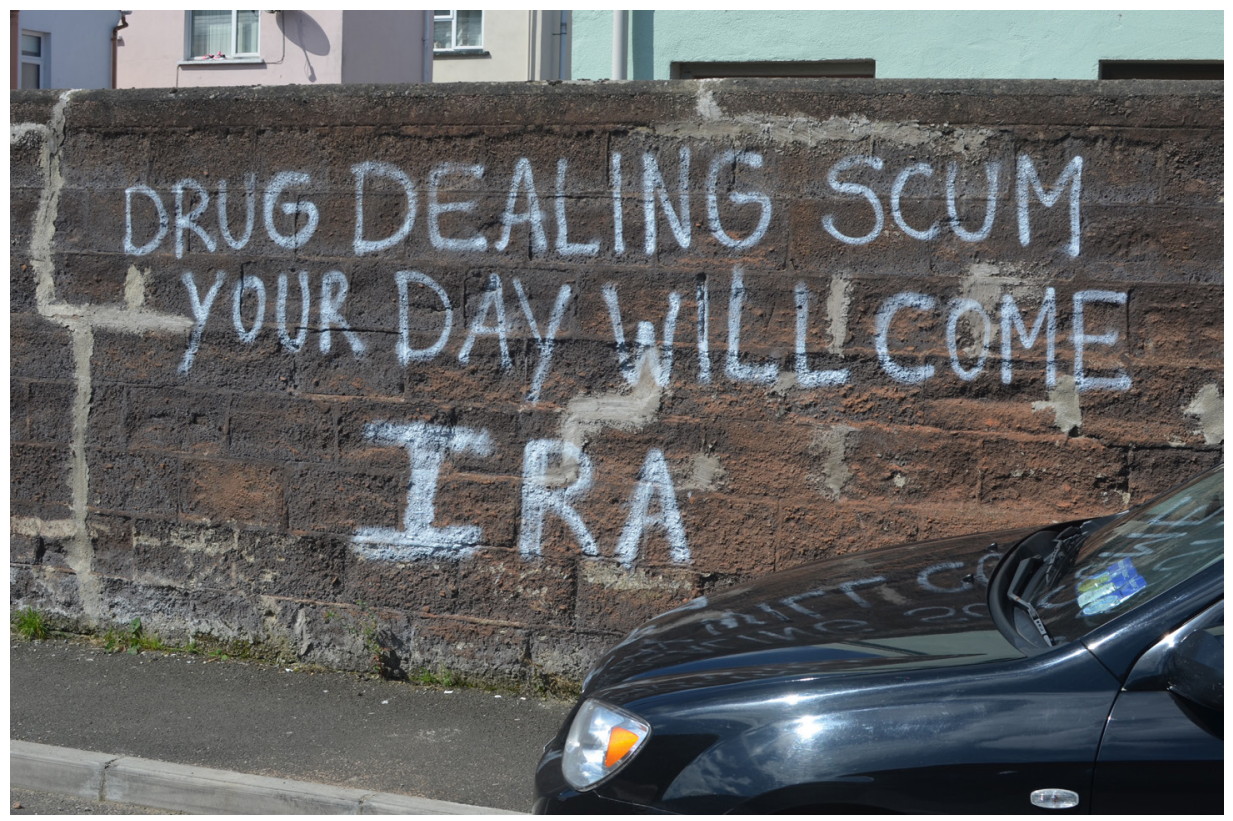

Figure 2.49. Photographs showing examples of anti-drug/paramilitary graffiti within the Bogside; August 2016 (Photograph taken by author)

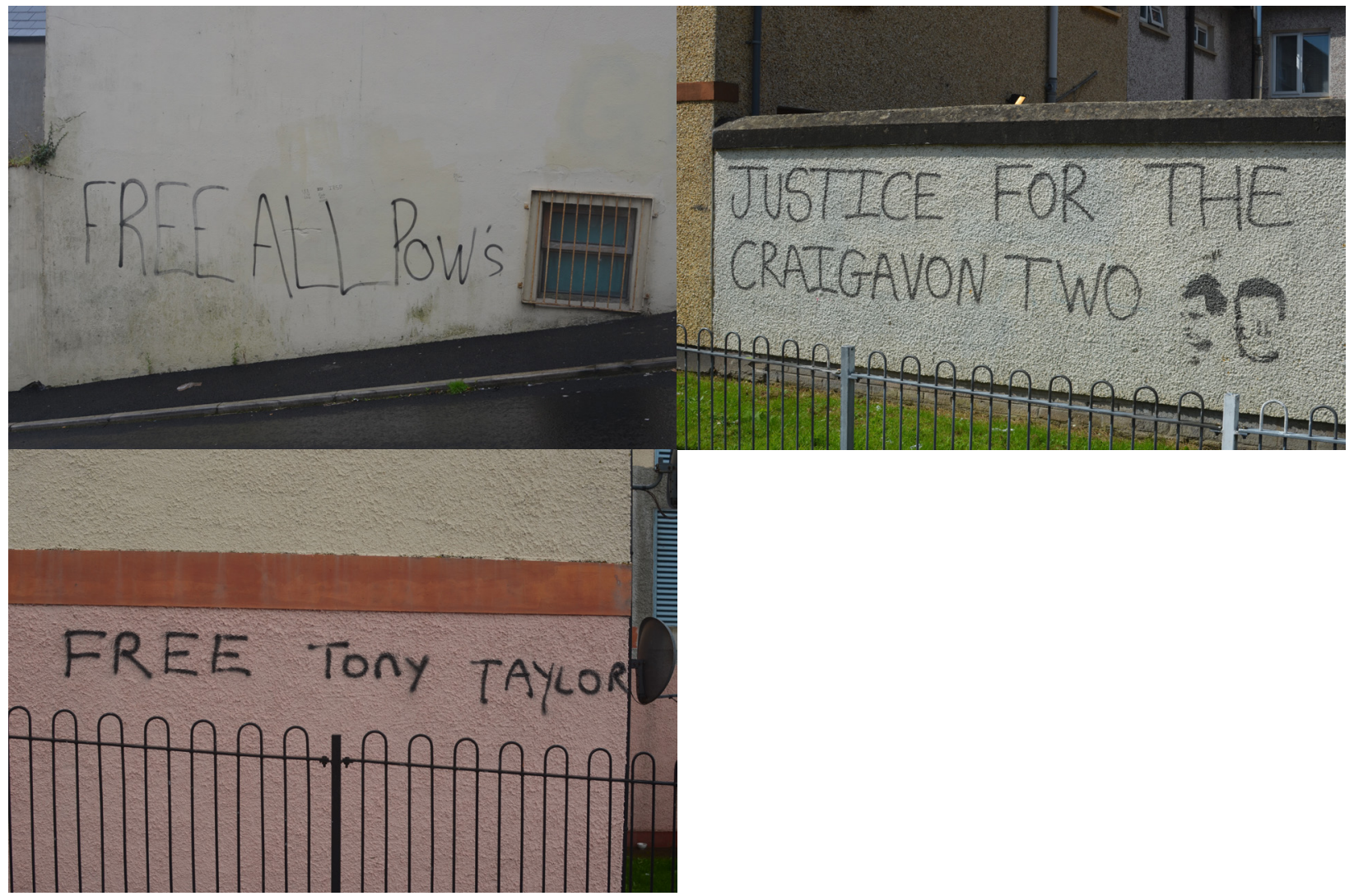

Figure 2.50. Photographs showing examples of political graffiti related to injustice and imprisonment within the Bogside; August 2016 (Photograph taken by author) 


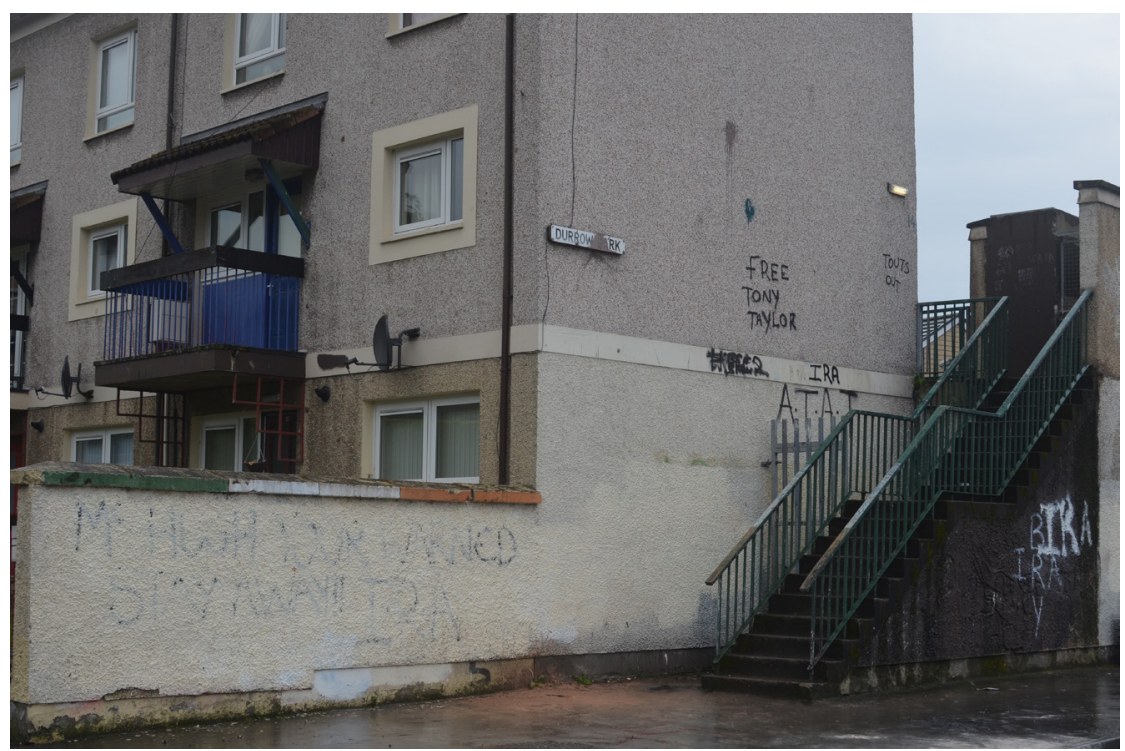

Figure 2.51. Photographs showing an attempt to paint over potentially controversial political graffiti within the Bogside; August 2016 (Photograph taken by author)
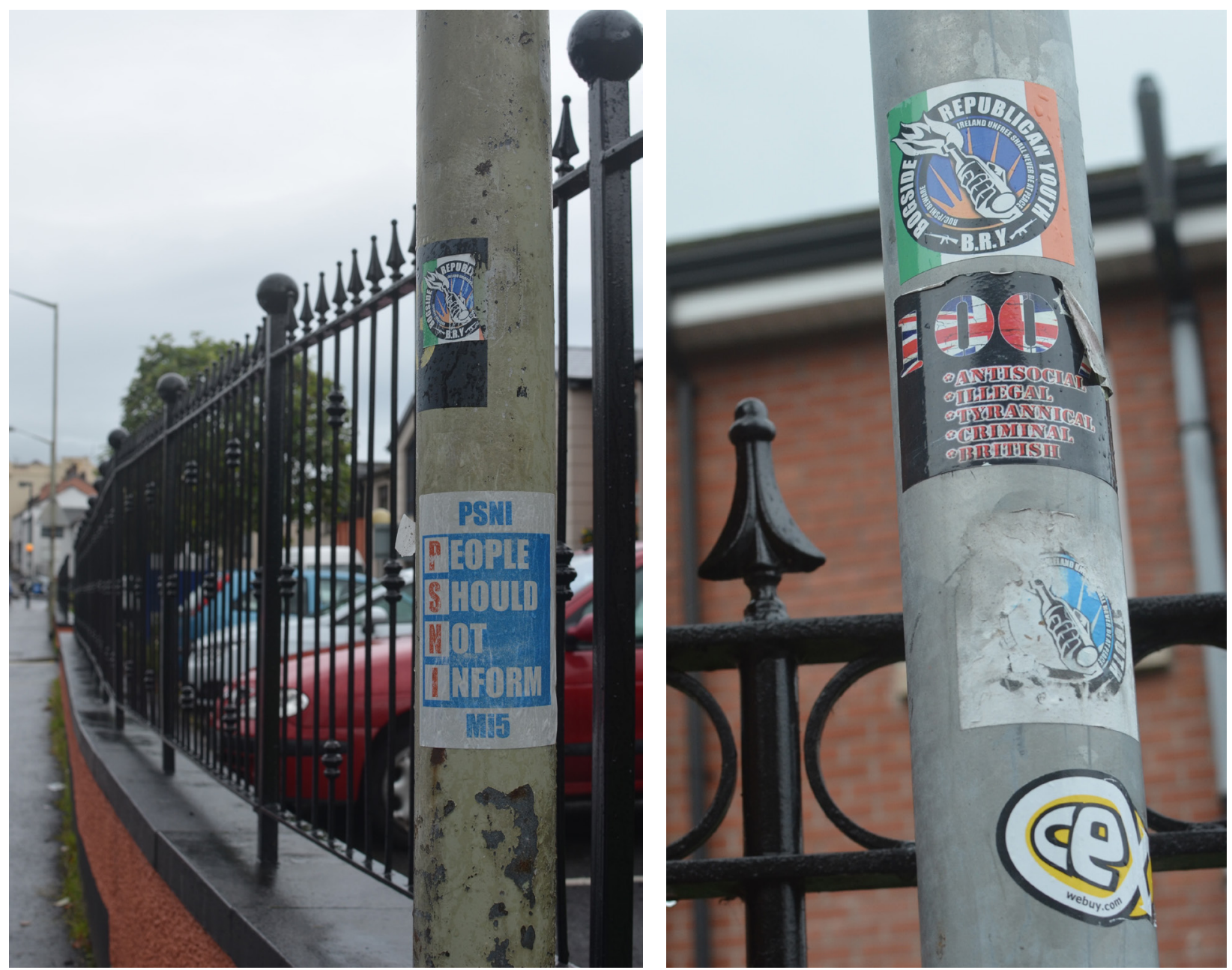

Figure 2.52. Photographs depicting political ephemera within the Bogside related to radical organizations and anti-police attitudes; August 2016 (Photograph taken by author) 


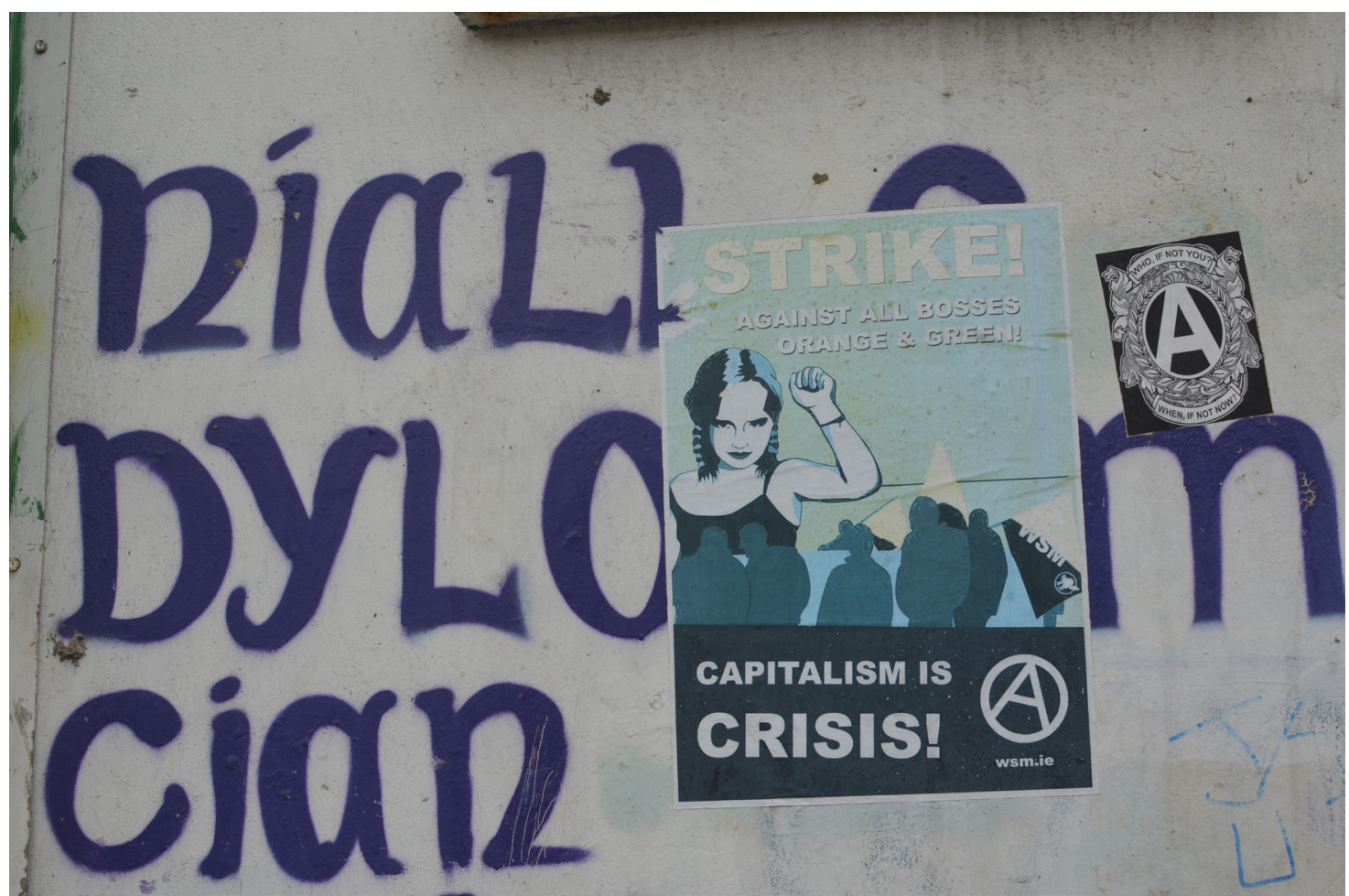

Figure 2.53. Photograph showing political posters for anarchist and workers' socialist political groups within the Bogside; August 2016 (Photograph taken by author)

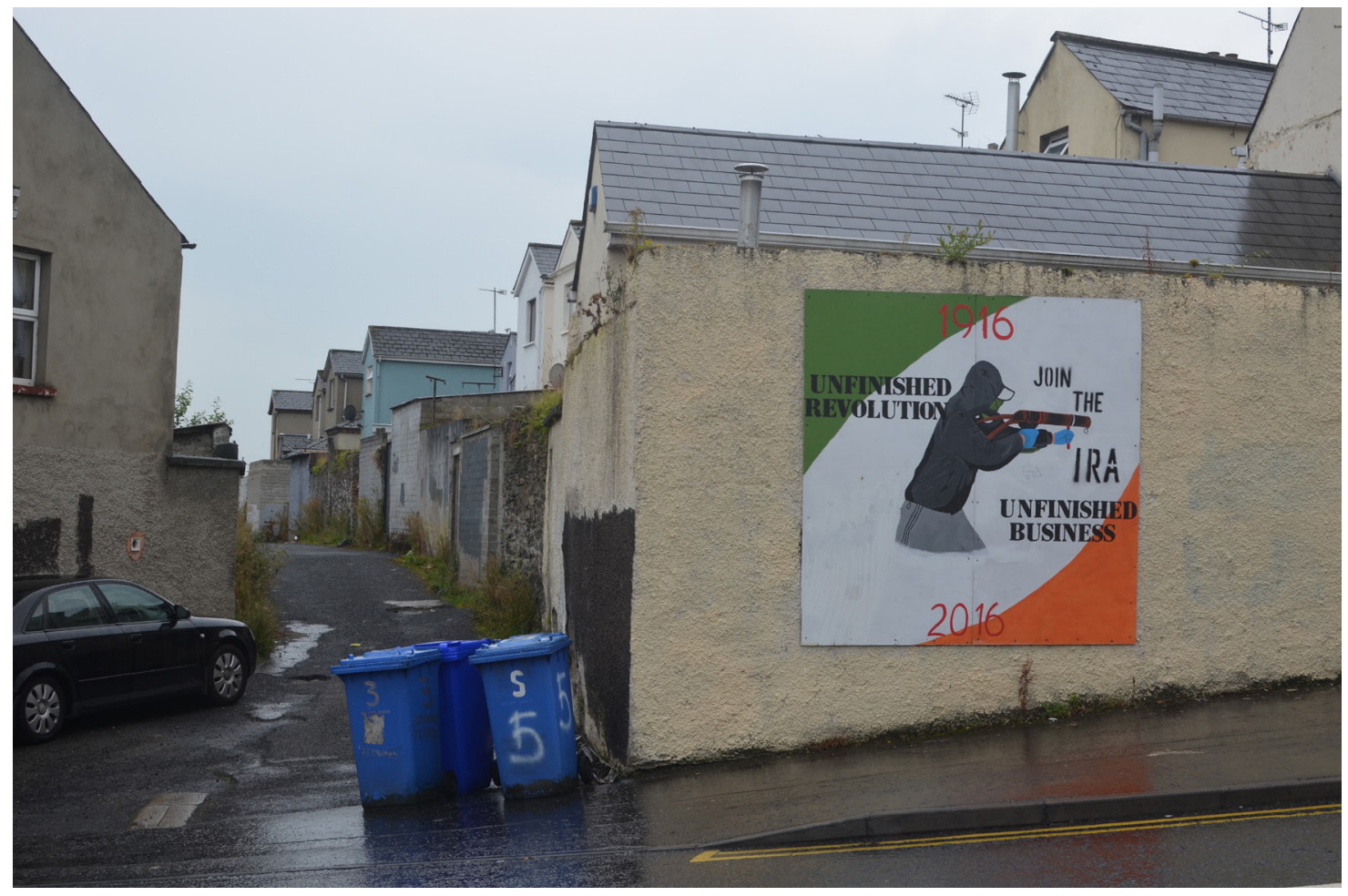

Figure 2.54. Photograph showing IRA recruitment signboard within the Bogside; August 2016 (Photograph taken by author) 


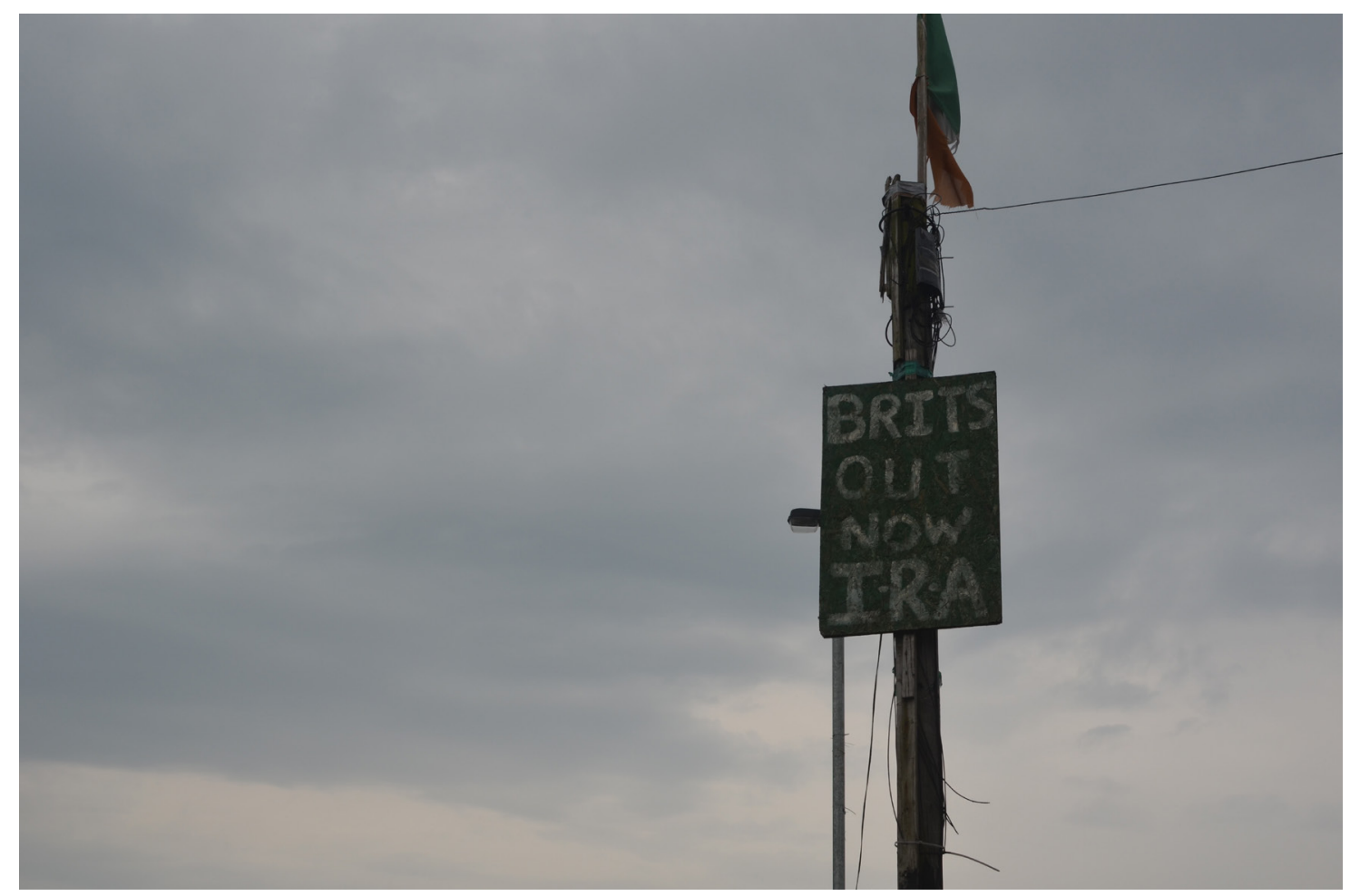

Figure 2.55. Photograph showing "Brits Out Now - IRA" signboard mounted beneath an Irish tricolour flag within the Bogside; August 2016 (Photograph taken by author)

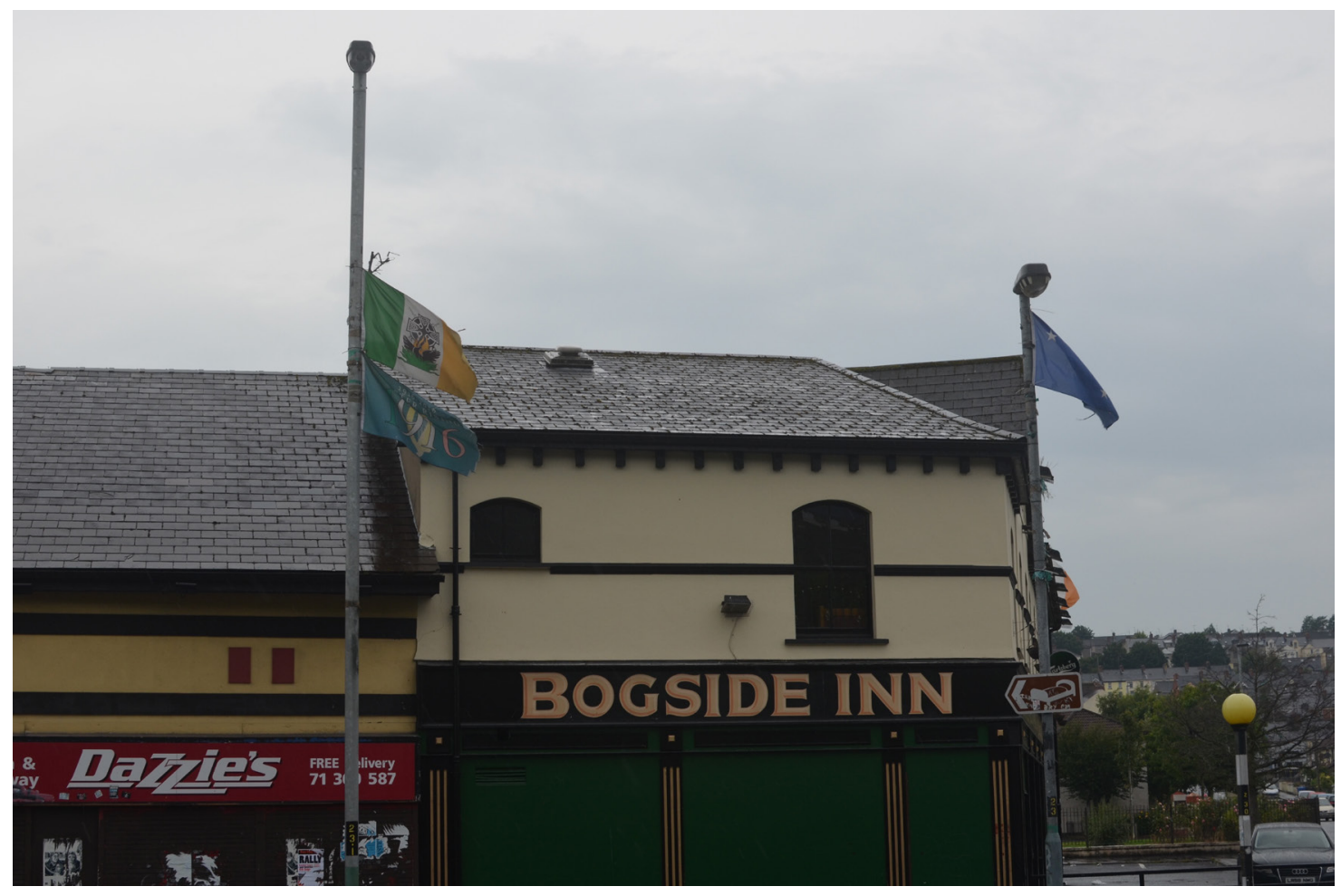

Figure 2.56. Photograph showing a Starry Plough flag (right), a variation of the Irish tricolour, and an Easter Rebellion commemorative flag being flown within the Bogside; August 2016 (Photograph taken by author) 


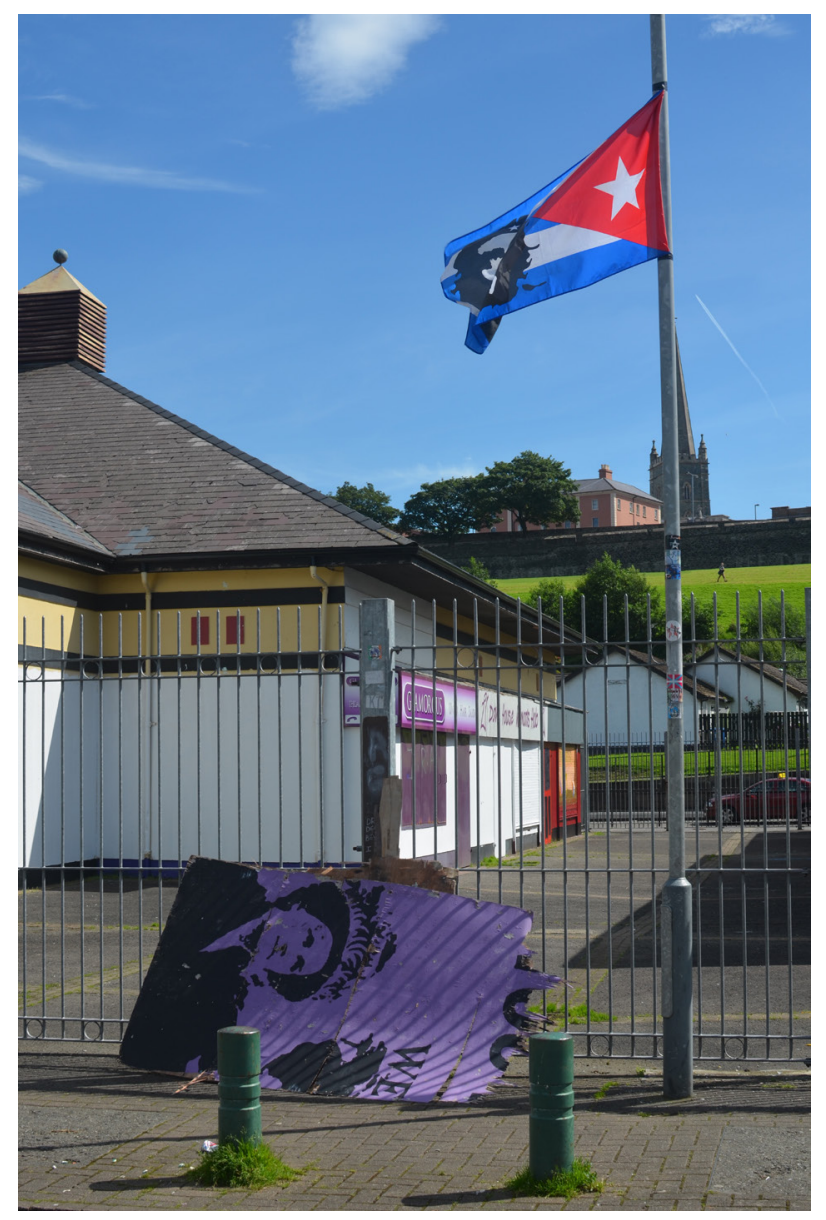

Figure 2.57. Photograph showing a Cuban flag depicting Che Guevara being flown within the Bogside; August 2016 (Photograph taken by author)

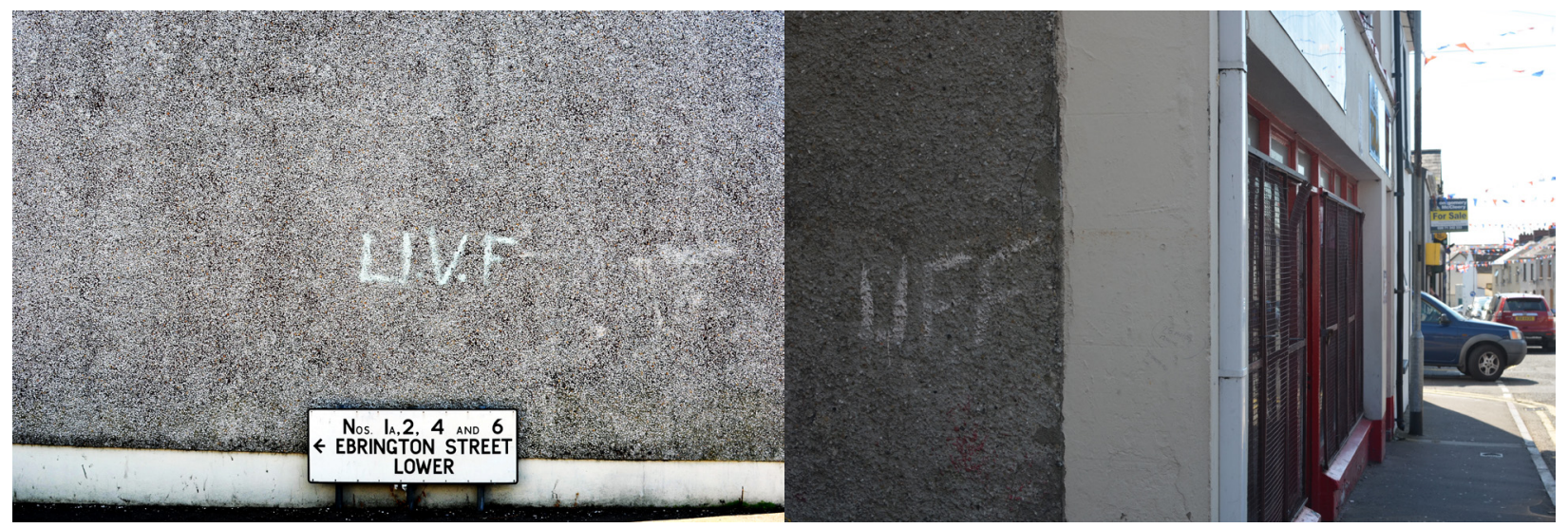

Figure 2.58. Photograph showing Loyalist paramilitary graffiti within the Waterside neighborhood; August 2016 (Photograph taken by author) 

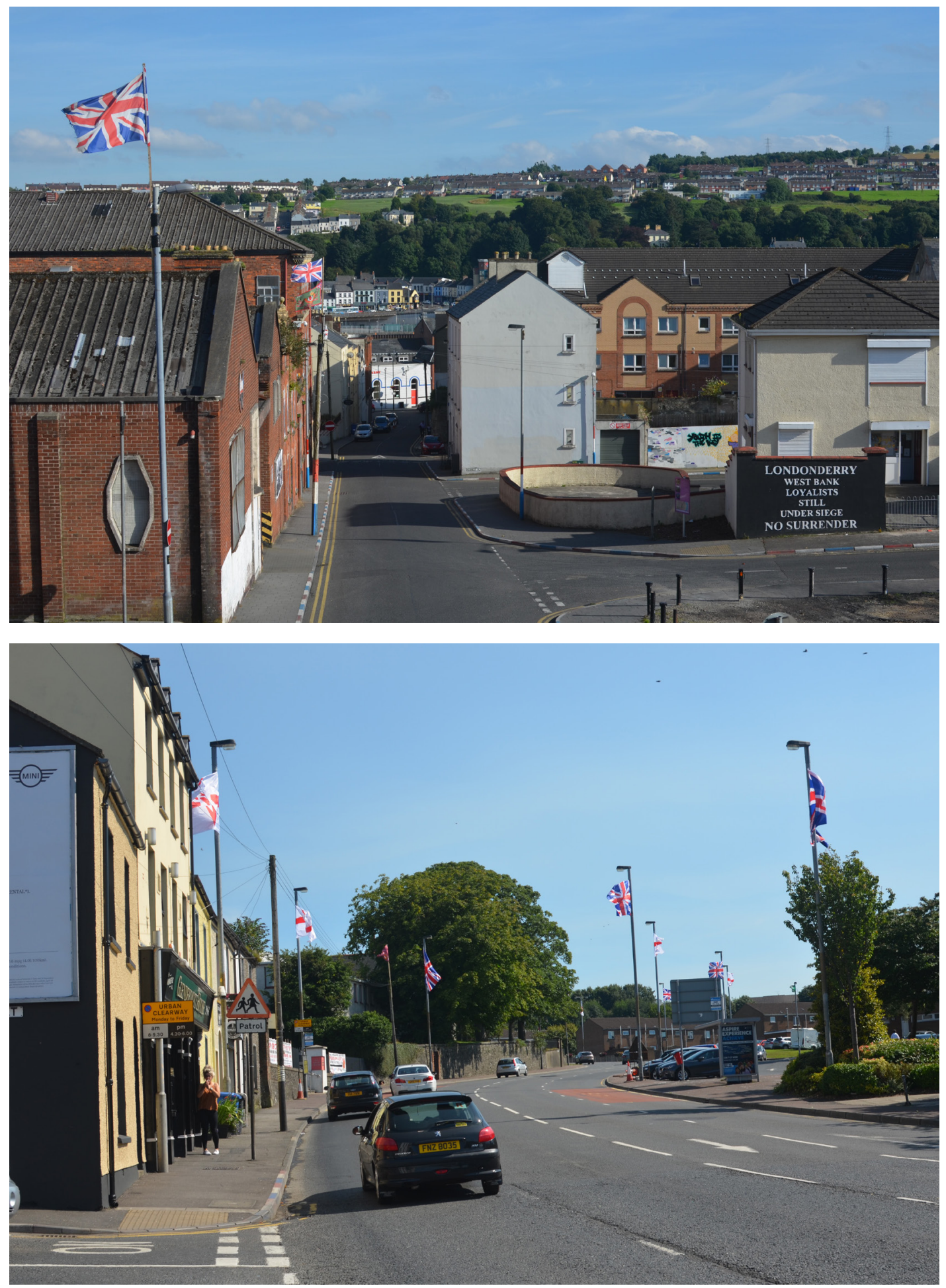

Figure 2.59. Photographs showing the prevalence of British flags and similarly colored painting schemes in the Fountain (above) and Waterside (below) areas; August 2016 (Photographs taken by author) 

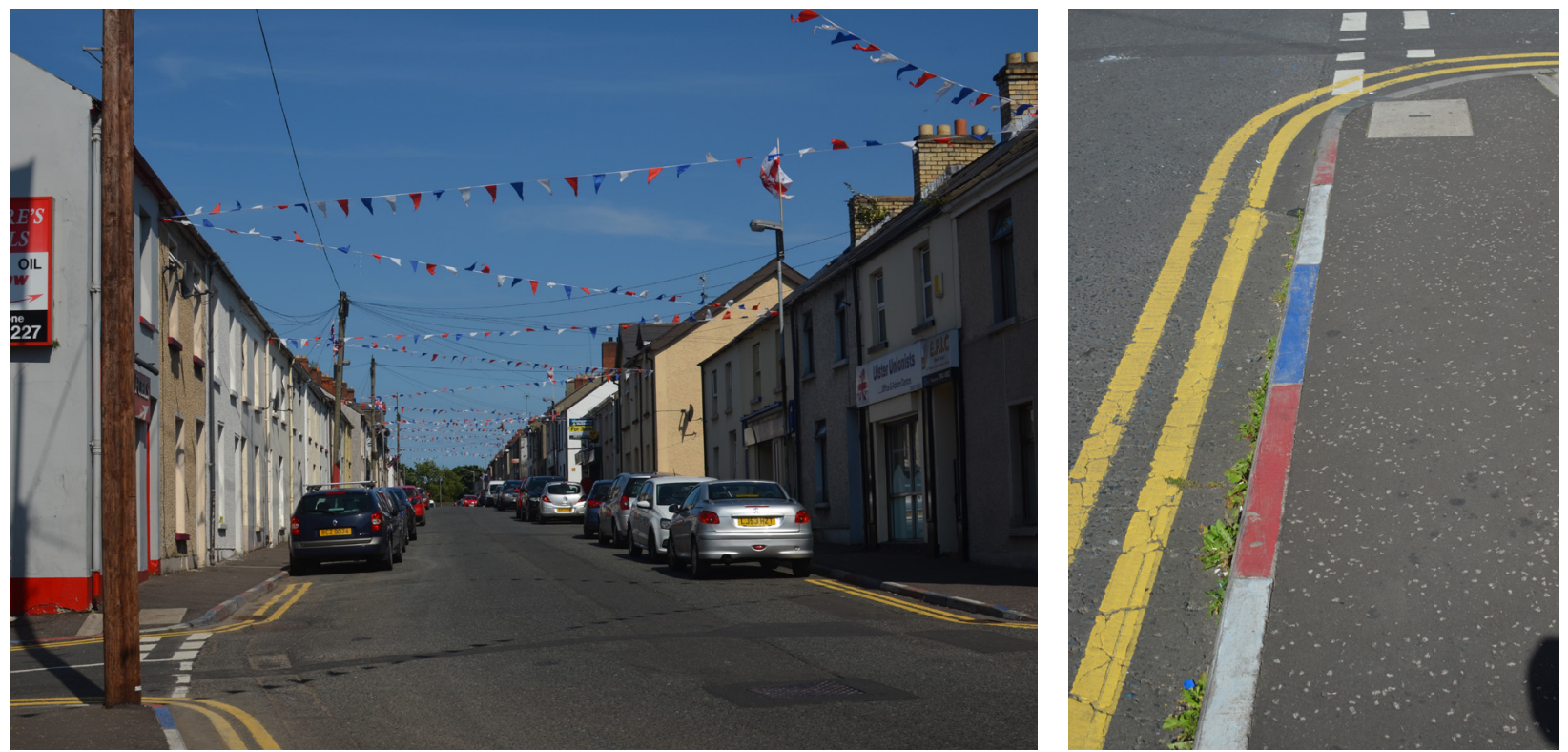

Figure 2.60. Photographs showing colored banners being flown over a roadway (left) and a detailed view of curbstone painting (right) in the Waterside neighborhood; August 2016 (Photograph taken by author) 


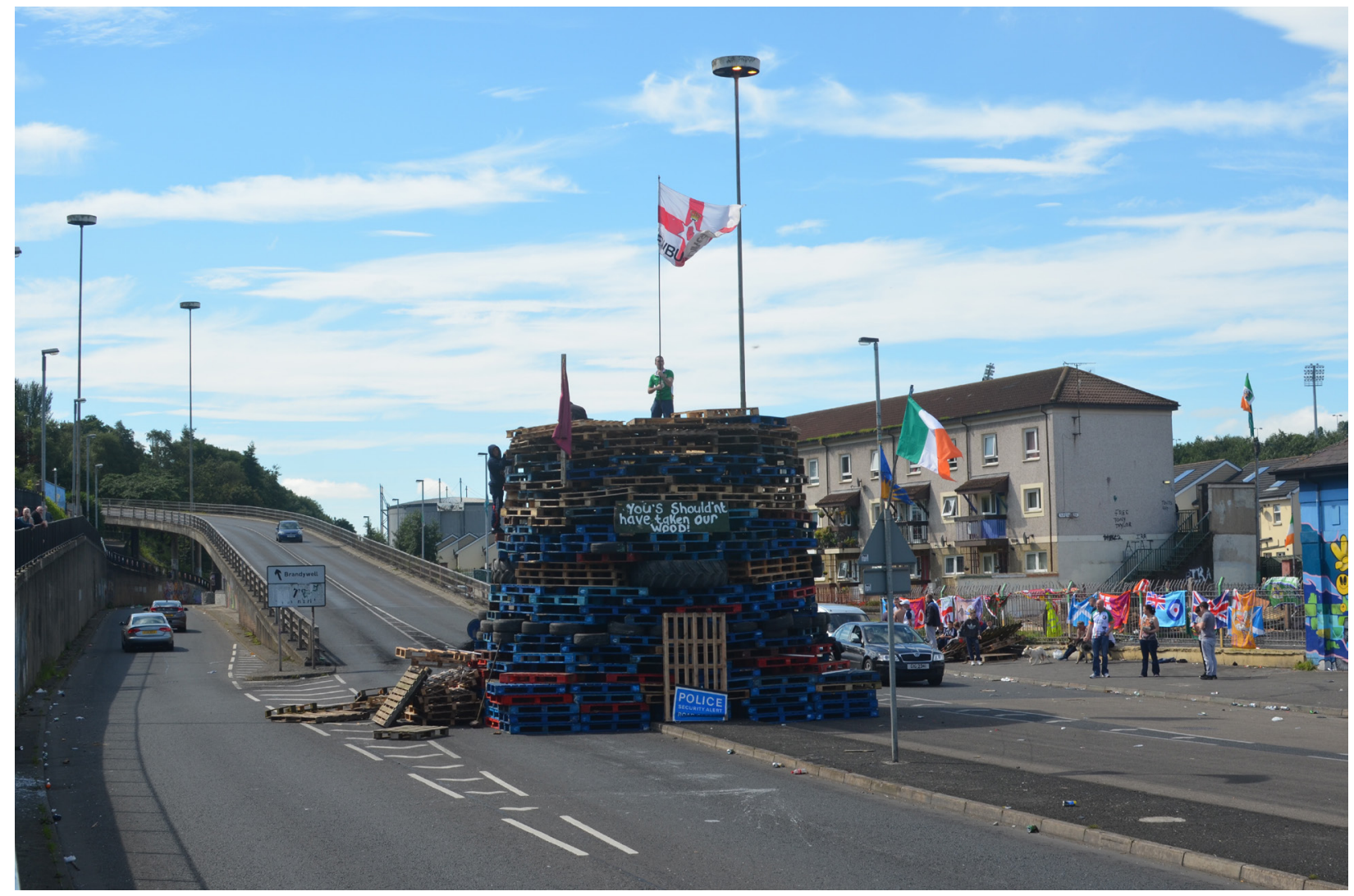

Figure 3.1. Photograph of Bogside bonfire during construction, with Lecky Rd. flyover behind; August 15, 2016. (Photo taken by author) 


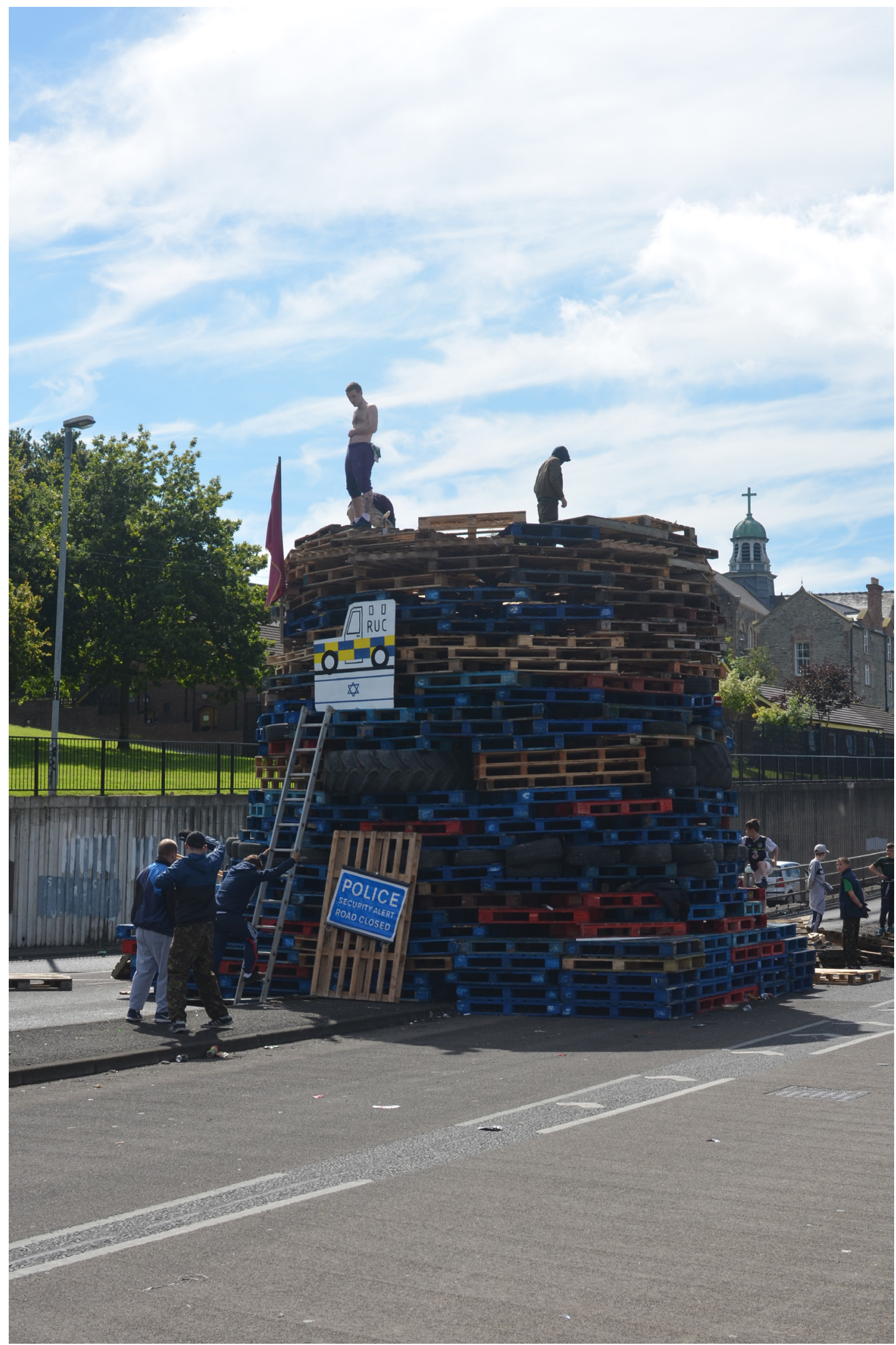

Figure 3.2. Photograph of Bogside bonfire showing RUC cutout mounted to front; August 15, 2016. (Photo taken by author) 


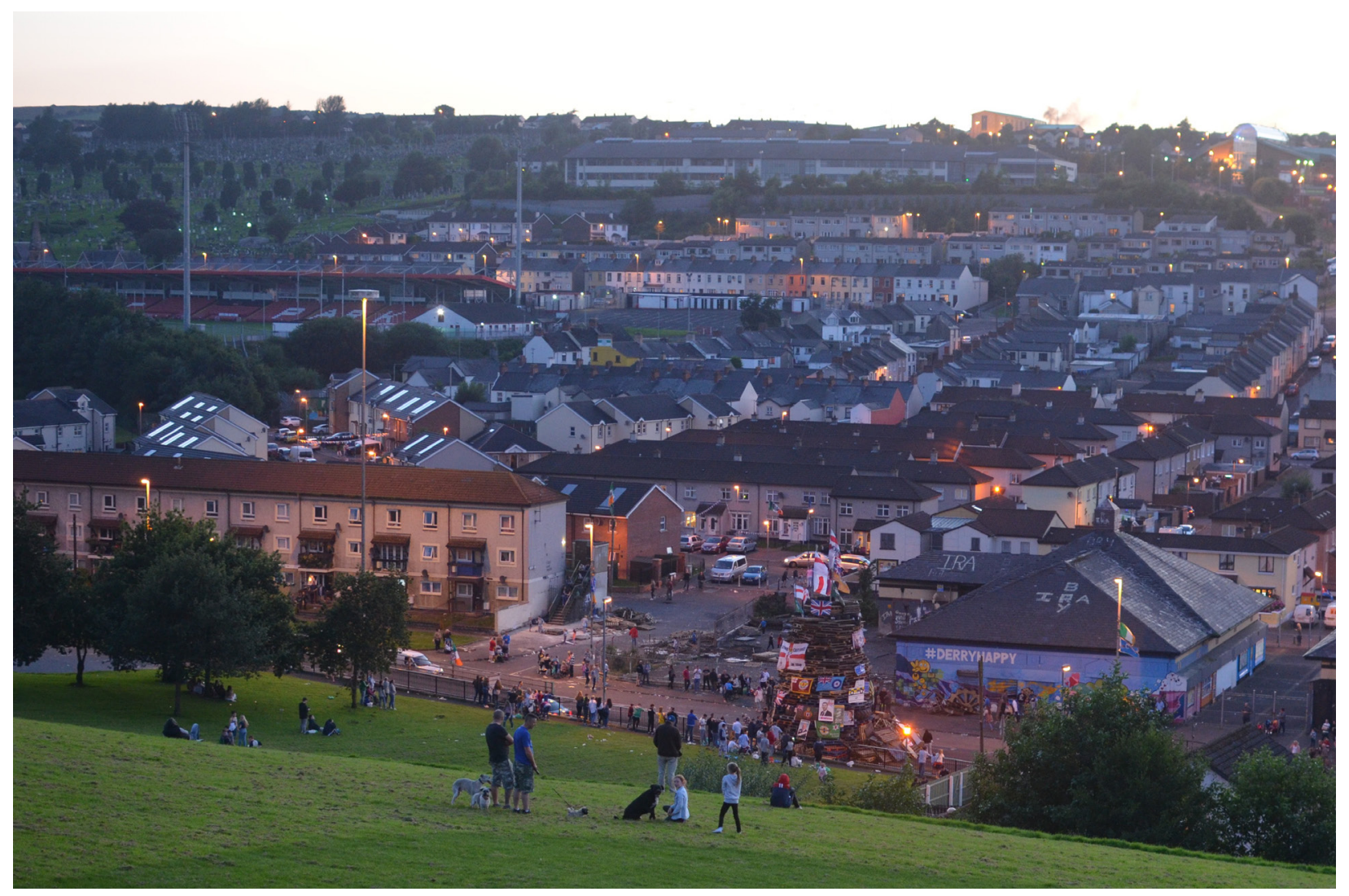

Figure 3.3. Photograph of the Bogside bonfire showing attached political posters and flags, view from Derry city walls; August 15, 2016. (Photo taken by author) 


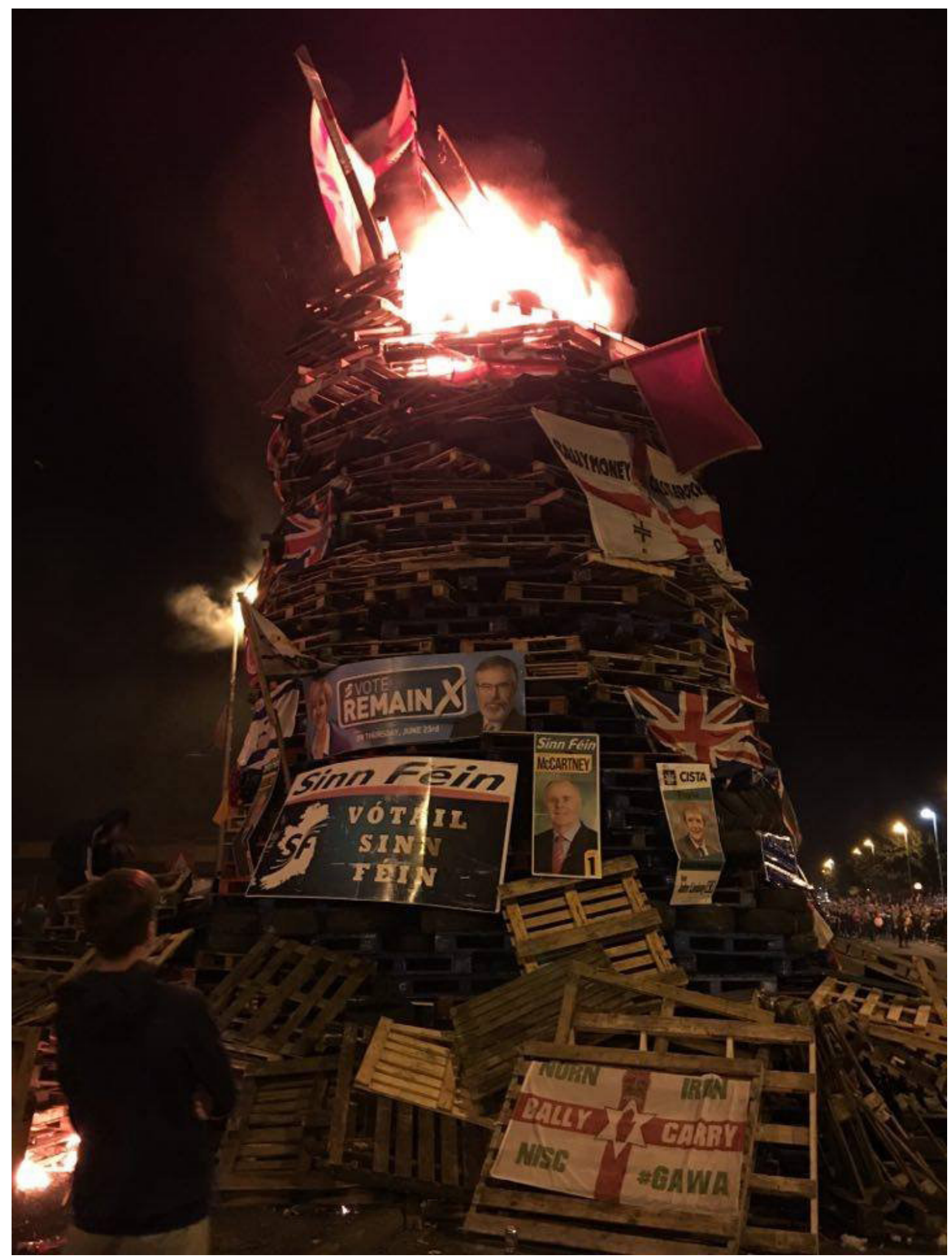

Figure 3.4. Photograph of Bogside bonfire showing Sinn Fein political posters; August 15, 2016. (Source: Derry Journal, https://twitter.com/derryjournal/status/765501330114879488?lang=en) 


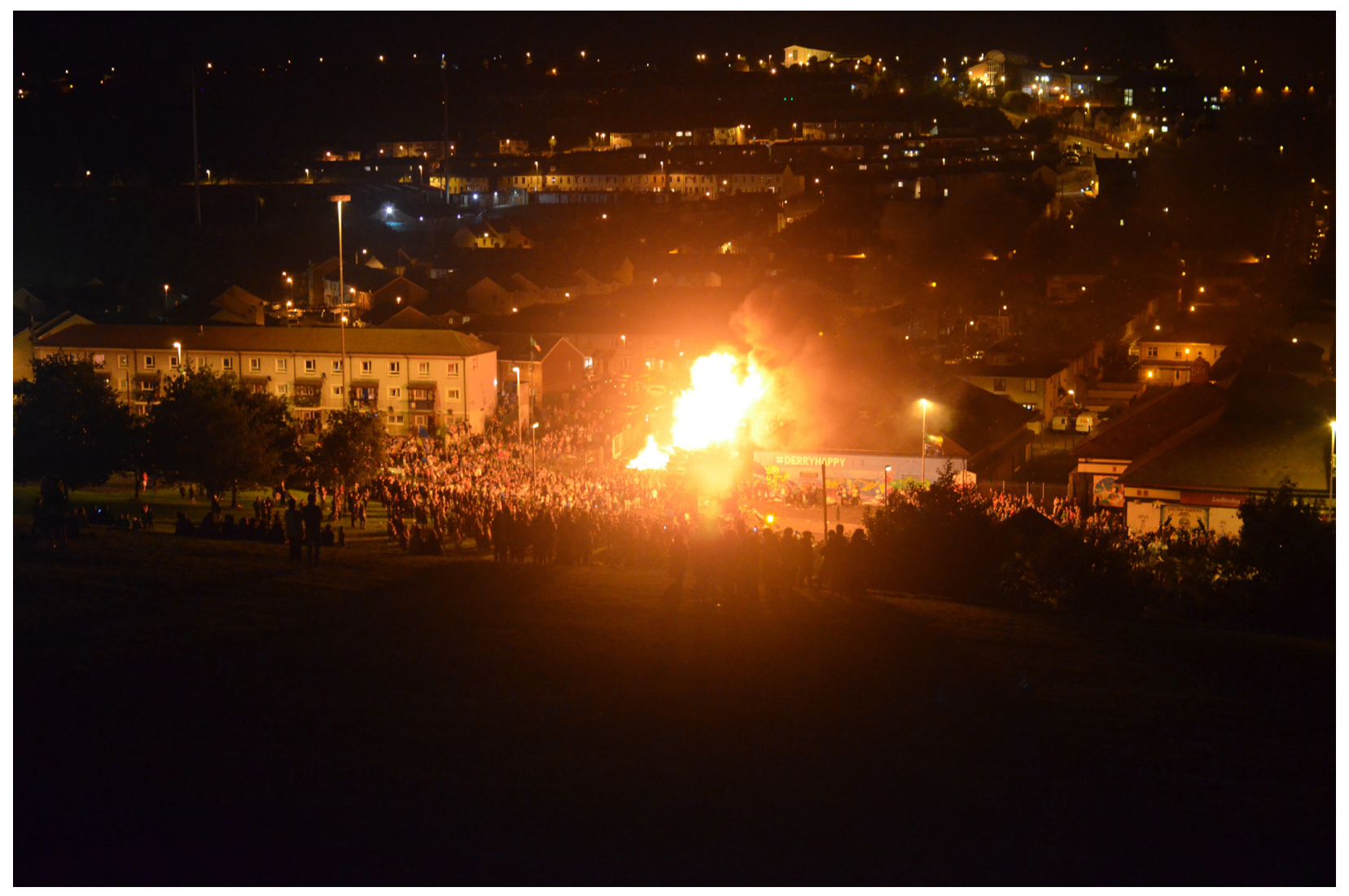

Figure 3.5. Photograph of the Bogside bonfire ablaze, view from Derry city walls; August 15, 2016. (Photo taken by author) 


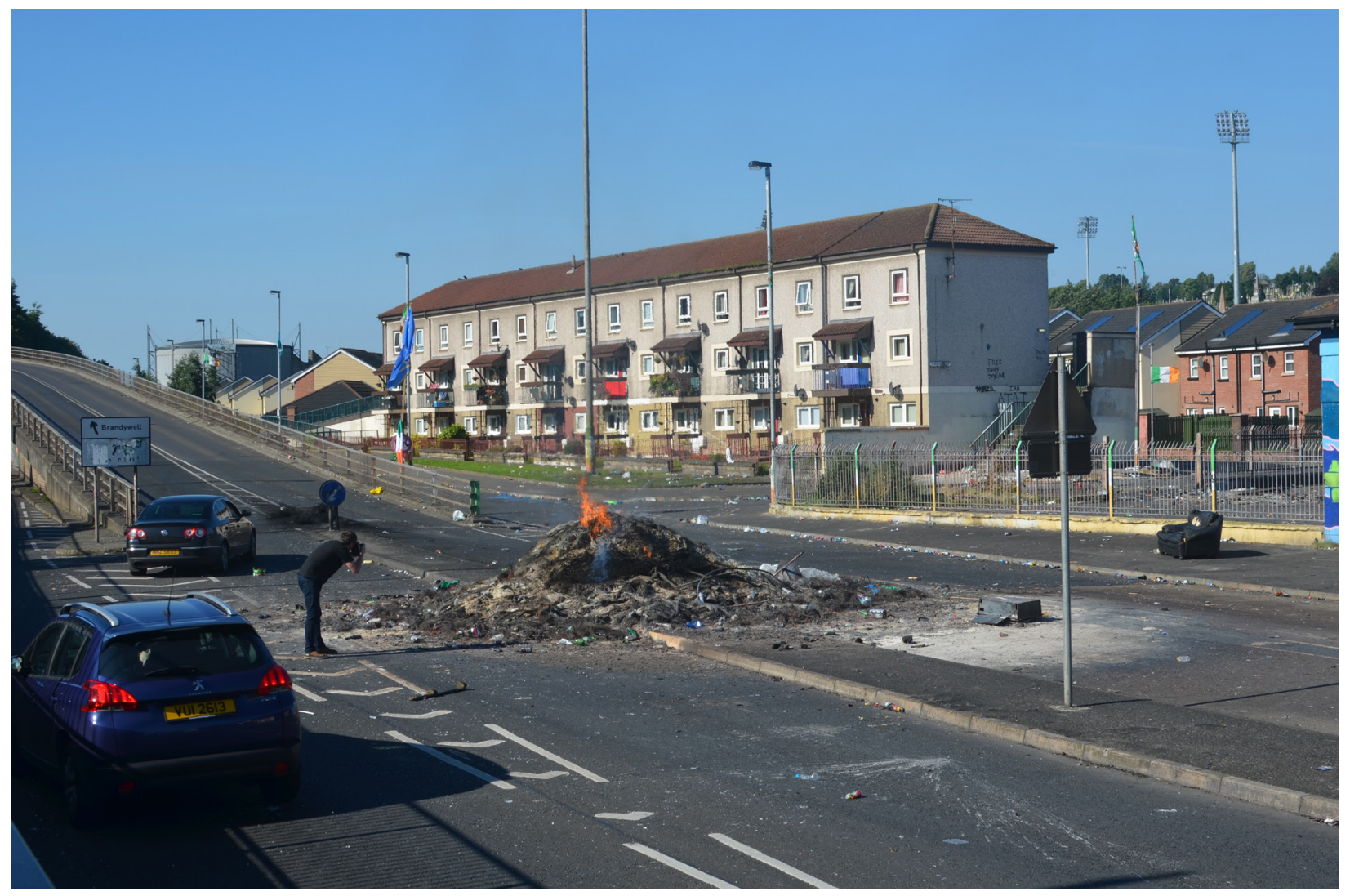

Figure 3.6. Aftermath of the Bogside bonfire, morning of August 16, 2016. (Photo taken by author) 


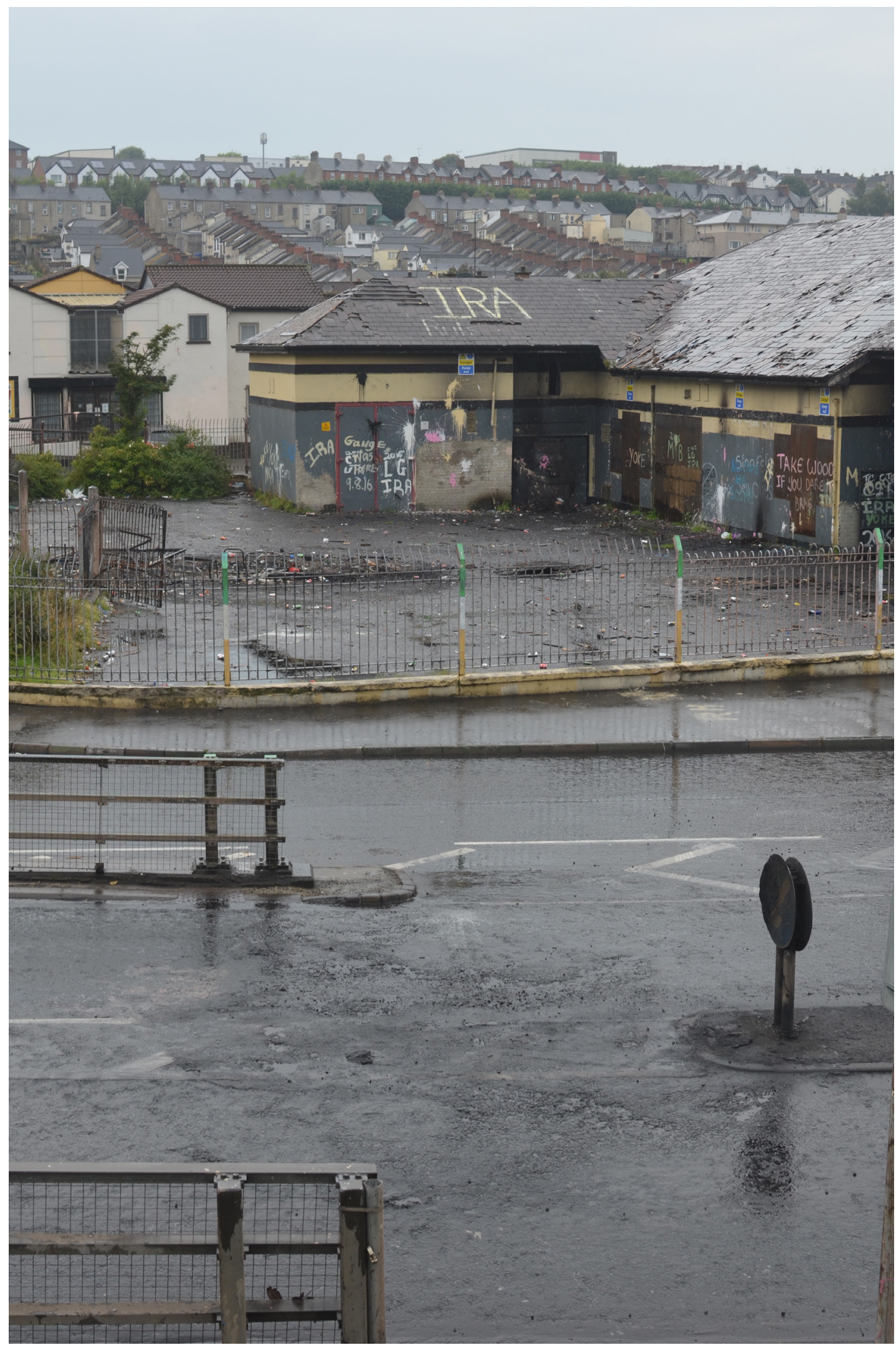

Figure 3.7. Aftermath of the Bogside bonfire, showing scarring and discoloration of roadway; August 17, 2016. (Photo taken by author) 

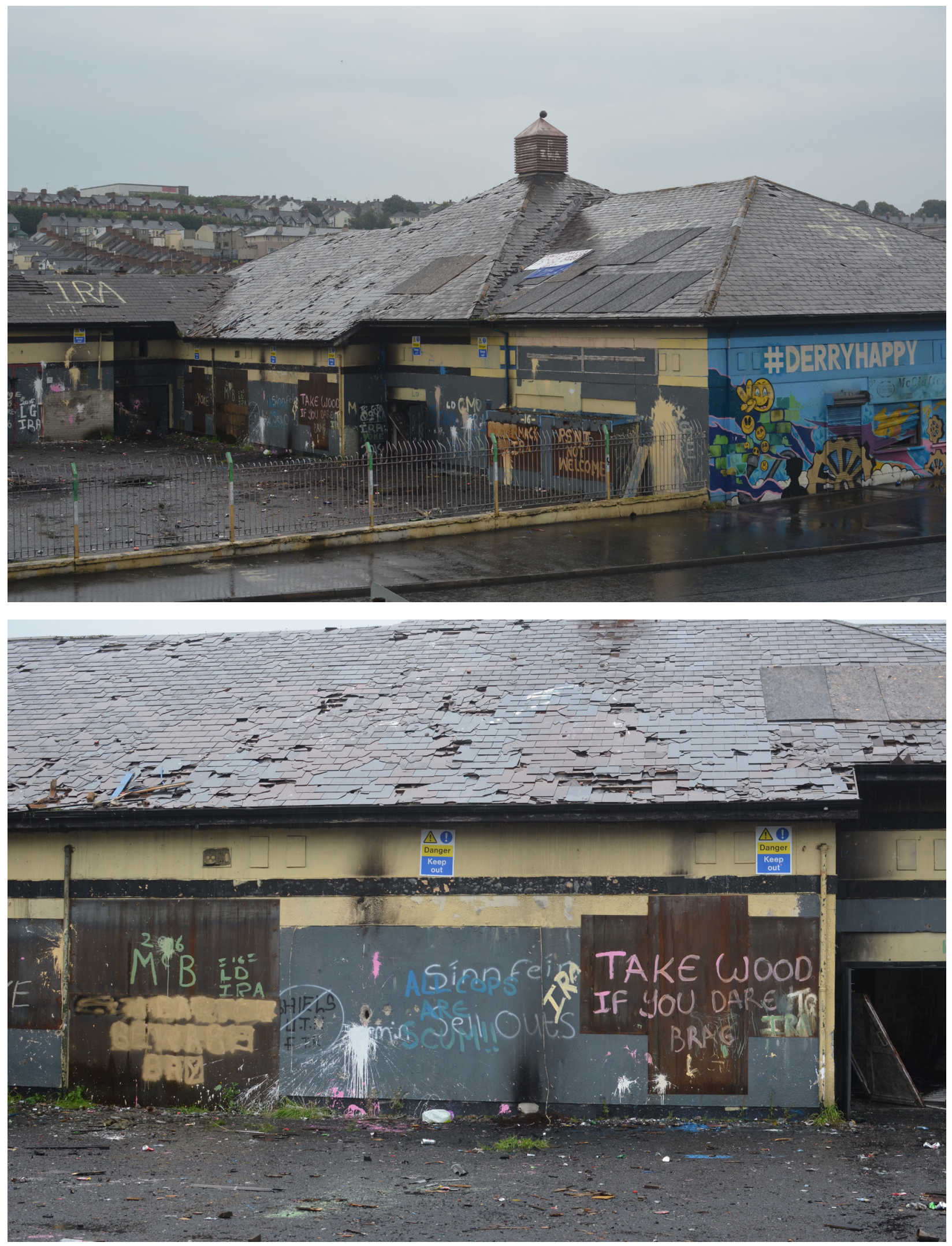

Figure 3.8. Aftermath of the Bogside bonfire, showing graffiti and damage to adjacent warehouse building; August 17, 2016. (Photos taken by author) 